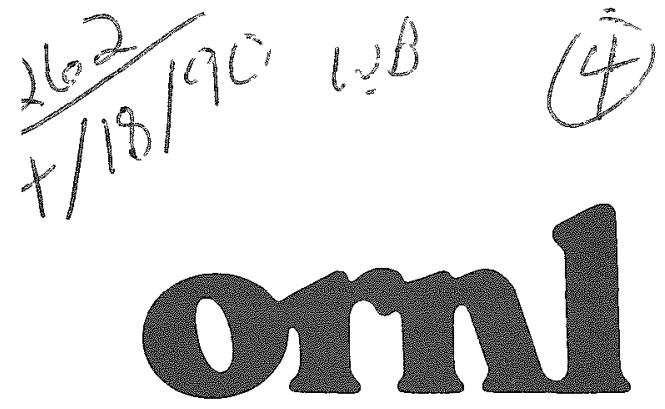

OAK RIDGE

NATIONAL LABORATORY

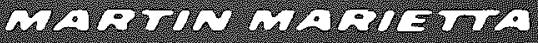

ORNL/SUb/86-SA094/6

JAl-314
Acceptance of Spent Nuclear Fuel in Multiple Element Sealed Canisters by the Federal Waste Management System

I MOI TIIHOFHL.

COVER 
This report has bean reproducad directly from the best available copy.

Available to DOE and DOE contrachors from the Ofice of Scientitic and Technical hrormation, P.O. Box 62, Oak Ridge, TV 37831 ; prices available from (615) 576-8401, FTS 626-8401.

Avallable to the public from the National Technical Intormation Service, U.S. Deparment of Commerce, 5285 port Poyal Rd. Springfield, VA 22161.

NTIS price codes-Printed Copy: 110 Microtiche A01

This report was prepared as an account of mork sponsored by an agency of the United Stan Govarnment. Neither the United States Govermon nor any agency thereof, nor any of their employees, makes any warranty, express or impled, or assumos any legal lability or premonsibily for the accuracy, comploteness, or userulness of any informa:ion, apparatus, product, or process disclosed, or represents that ils use would not inirnge privately owned rights.

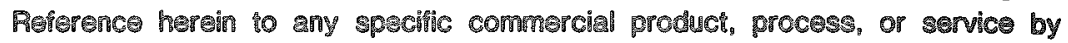
irade name, trademark, manuiacurer, or otherwise, doss not necessarily consti. tute or imply iss endorsement, recommendation, or favorng by the United States Govermment or any agency thereof. The views and opinions of authors expressed herein do not necossarily state or reflect those of the United States Government or any agency thereof. 


\section{DISCLAIMER}

This report was prepared as an account of work sponsored by an agency of the United States Government. Neither the United States Government nor any agency Thereof, nor any of their employees, makes any warranty, express or implied, or assumes any legal liability or responsibility for the accuracy, completeness, or usefulness of any information, apparatus, product, or process disclosed, or represents that its use would not infringe privately owned rights. Reference herein to any specific commercial product, process, or service by trade name, trademark, manufacturer, or otherwise does not necessarily constitute or imply its endorsement, recommendation, or favoring by the United States Government or any agency thereof. The views and opinions of authors expressed herein do not necessarily state or reflect those of the United States Government or any agency thereof. 


\section{DISCLAIMER}

Portions of this document may be illegible in electronic image products. Images are produced from the best available original document. 


\title{
ACCEPTANCE OF SPENT NUCLEAR FUEL IN MULTIPLE \\ ELEMENT SEALED CANISTERS BY THE FEDERAL WASTE MANAGEMENT SYSTEM
}

Date Published - March 1990

\author{
Prepared by \\ E. R. Johnson Associates, Inc. \\ 10461 White Granite Drive \\ Suite 204 \\ Oakton, Virginia 22124 \\ under \\ Purchase Order No. 41X-SA094V \\ Prepared for \\ OAK RIDGE NATIONAL LABORATORY \\ Oak Ridge, Tennessee 37831-6285 \\ operated by \\ MARTIN MARIETTA ENERGY SYSTEMS, INC. \\ for the \\ U.S. DEPARTMENT OF ENERGY \\ under contract DE-AC05-840R21400
}





\section{FOREWORD}

This report is one of a series of eight prepared by E. R. Johnson Associates, Inc. (JAI) under ORNL's contract with DOE's OCRWM Systems Integration Program and in support of the Annual Capacity Report (ACR) Issue Resolution Process. The report topics relate specifically to the list of high priority technical waste acceptance issues developed jointly by DOE and a utility-working group. JAI performed various analyses and studies on each topic to serve as starting points for further discussion and analysis leading eventually to finalizing the process by which DOE will accept spent fuel and waste into its waste management system. The eight reports are concerned with the conditions under which spent fuel and high level waste will be accepted in the following categories:

1. Failed Fuel

2. Consolidated Fuel and Associated Structural Parts

3. Non-Fuel-Assembly Hardware

4. Fuel in Metal Storage Casks

5. Fuel in Multi-Element Sealed Canisters

6. Inspection and Testing Requirements for Wastes

7. Canister Criteria

8. Spent Fuel Selection for Delivery

9. Defense and Commercial High-Level Waste Packages

As a part of the report preparation, each was subjected to a rigorous peer review by a group of knowledgeable and independent experts. These reports. have not yet been formally reviewed by DOE and, therefore, do not represent DOE policy. 

Page

1.0 INTRODUCTION AND BACKGROUND 1-1

2.0 SUMMARY 2-1

2.1 Impacts on From-Reactor Transportation 2-1

2.2 Impacts on FWMS Facilities 2-2

2.3 Summary of Estimated Incremental Unit Costs or Savings 2-3

2.4 The Issue of MESC Acceptance 2-6

3.0 USE OF MESCS FOR AT-REACTOR STORAGE OF SPENT FUEL $3-1$

3.1 Description of the Use of MESCs for At-Reactor Storage 3-1

3.2 Plans for Use of MESCs by Utilities 3-7

4.0 IMPACTS OF ACCEPTANCE OF SNF IN MESCS ON THE FWMS 4-1

4.1 Impacts on From-Reactor Shipping 4-1

4.1.1 Anaiys is of Impacts on Shipments 4-1

4.1.2 Estimates of Transportation-Related Cost Impacts 4-3

4.1.2.1 Estimated Cost of the Reference Shipping 4-3

4.1.2.2 Estimated Cost of MESC Shipping Casks 4-4

4.1.2.3 Estimate of Freight and Other Costs 4-14

Associated With Cask Use
4.1.2.4 Life Cycle Transport Costs and Unit 4-19 Costs

4.2 MESC Processing in FWMS Facilities 4-23

4.2.1 Processing A7ternatives for MESCs 4-23

4.2.2 Reference Facility Design $4-26$

4.2.3 Estimates of Cost Impacts at FWMS Facilities 4-28

4.2.3.1 Cost of Equi pment for Cutting Open 4-30

4.2.3.2 Operating Costs for Cutting Open MESCs 4-31

Outside of Hot Cell Facilities
4.2.3.3 Cost of MESC Disposal

4.2.3.4 Cost of Additions to ACD Facility 4-33

Receiving and Hot Cell Facilities
4.2.3.5 Additional Costs of Operations at ACD

Facility Receiving and Hot Cell

Facilities

4.2.3.6 Cost of MRS Casks and Storage Modules 4-37

4.3.2.7 Cost of Additions to Storage Areas 4-41

4.2.3.8 Additional Cost of Operations in Storage 4-42

4.2.3.9 Decommissioning Costs 4-44

4.2.3.10 Incremental Life Cycle and Unit Costs 4-44 for Handling MESCs in FWMS Facilities 
TABLE OF CONTENTS (Continued)

5.0 SUMMARY OF INCREMENTAL UNIT COSTS TO THE FWMS 5-1

6.0 POLICY ALTERNATIVES AVAILABLE TO DOE REgARDING MESCS 6-1

6.1 Decline to Accept MESCs 6-1

6.2 Acceptance of MESCs 6-2

6.2.1 Acceptance With No Charge For Added Costs 6-2

6.2.2 Acceptance With A Charge For Added Costs 6-3

6.2.3 Conditions of Acceptance 6-4

6.3 Summary of Alternatives 6-6

$\begin{array}{ll}7.0 & \text { REFERENCES } \\ 7-1\end{array}$

8.0 DEFINITIONS 8-1

APPENDIX A LIFE CYCLE TRANSPORT COSTS AND UNIT COST CALCULATIONS

ASSOCIATED WITH THE USE OF A SINGLE REFERENCE SHIPPING

CASK OR MESC SHIPPING CASK -- CASKS FULLY UTILIZED

EITHER EXCLUS IVELY FOR SHIPMENT OF INDIVIDUAL PWR

ASSEMBLIES OR FOR MESCS CONTAINING PWR ASSEMBLIES

APPENDIX B LIFE CYCLE TRANSPORT COSTS AND UNIT COST CALCULATIONS

ASSOCIATED WITH THE USE OF A SINGLE 24 PWR ASSEMBLY MESC

SHIPPING CASK - - CASKS USED EITHER EXCLUSIVELY FOR

SHIPMENT OF MESCS TO EXTENT AVAILABLE OR FULLY UTILIZED

FOR SHIPMENT OF INDIVIDUAL FUEL ASSEMBLIES AND MESCS

APPENDIX $C$ LIFE CYCLE TRANSPORT COSTS AND UNIT COST CALCULATIONS

ASSOCIATED WITH THE USE OF A SINGLE 7 PWR ASSEMBLY MESC

SHIPPING CASK - - CASKS USED EITHER EXCLUSIVELY FOR

SHIPMENT OF MESCS TO EXTENT AVAILABLE OR FULLY UTILIZED

FOR SHIPMENT OF INDIVIDUAL FUEL ASSEMBLIES AND MESCS

APPENDIX D LIFE CYCLE TRANSPORT COSTS AND UNIT COST CALCULATIONS ASSOCIATED WITH THE USE OF A SINGLE $2 / 7$ PUR ASSEMBLY MESC SHIPPING CASK - - CASKS USED EITHER EXCLUSIVELY FOR SHIPMENT OF MESCS TO EXTENT AVAILABLE OR FULLY UTILIZED FOR SHIPMENT

OF INDIVIDUAL FUEL ASSEMBLIES AND MESCS

APPENDIX E INCREMENTAL LIFE CYCLE COSTS AND UNIT COST CALCULATIONS

ASSOCIATED WITH THE PROCESSING OF MESCS IN FWMS FACILITIES

APPENDIX F EXPLANATION OF METHOD USED FOR THE CALCULATION OF UNIT COSTS 


\section{LIST OF TABLES}

Table No.

Description

Page

$2-1$

Estimated Incremental Unit Costs (or Savings) to

$2-4$

the FWMS Resulting From Receipt of SNF In MESCs

At A MRS Facility

2-2 Estimated Incremental Unit Costs (or Savings) to

the FWMS Resulting From Receipt of SNF In MESCs

At A Repository

4-1 From-Reactor SNF Shipping Cask Capacities,

$4-1$

Dimensions \& Weights

4-2 Conceptual Characteristics of MESC Shipping Casks

$4-2$

4-3 Cost of Reference Shipping Cask

Summary Breakdown of Total Per Cask Cost of Reference Shipping Casks and MESC Shipping Casks

4-5 Estimated Fabrication Cost of From-Reactor SNF Shipping Casks

4-6 Estimated Fabrication Cost of SNF Shipping Casks As a Function of the Number of Casks Built

4-7 Estimated Additional Costs Associated With the Fabrication of From-Reactor SNF Shipping Casks

4-8 Estimated Other Costs Associated With Fabrication of SNF Shipping Casks As A Function of the Numbers of Casks Built in a Single Procurement

4-9 Estimated Added Costs for Design and Development of MESC Shipping Casks

4-10 Added Cost of Reference Shipping Cask As A Result of Procurement of Fewer Numbers of a Given Design

4-11 Added Costs Attributable to MESC Casks As A Result

of Procurement of Fewer Numbers of Reference Shipping Casks

4-12 Freight Costs For A Single Round Trip Shipment of MESC Shipping Casks and the Reference Shipping Cask

4-13 Summary of Estimated Shipping Cask Disposal Costs 


\section{LIST OF TABLES (Continued)}

\begin{tabular}{|c|c|c|}
\hline able No. & Description & Page \\
\hline $4-14$ & $\begin{array}{l}\text { Comparison of Unit Costs for Transport of SNF in } \\
\text { Reference Shipping Cask and MESC Shipping Casks }\end{array}$ & $4-19$ \\
\hline $4-15$ & $\begin{array}{l}\text { Increase in Unit Costs for the Transport of PWR } \\
\text { Assemblies in MESCs Over Transport in Uncanistered } \\
\text { Condition in a Reference Shipping Cask }\end{array}$ & $4-21$ \\
\hline $4-16$ & $\begin{array}{l}\text { Estimated Cost of Equipment for Opening and Handling } \\
\text { of MESCs }\end{array}$ & $4-31$ \\
\hline $4-17$ & Estimated MESC Disposal Costs & $4-32$ \\
\hline $4-18$ & $\begin{array}{l}\text { Summary of Incremental Receiving and Handi ing } \\
\text { Facility Costs for Hot Cell Opening and Unloading } \\
\text { of MESCs }\end{array}$ & $4-35$ \\
\hline $4-19$ & Cost of MRS Casks for ACD Facility & $4-38$ \\
\hline $4-20$ & Estimated Costs of Concrete Storage Casks for MESCs & $4-39$ \\
\hline $4-21$ & $\begin{array}{l}\text { Estimated Cost of Equipment Required for Loading } \\
\text { MESCs From Shipping Casks Into Storage Modules at } \\
\text { the MRS Facility }\end{array}$ & $4-40$ \\
\hline $4-22$ & $\begin{array}{l}\text { Cask Emplacement Effort Comparison and Additional } \\
\text { Labor Costs for Emplacement of a MESC Cask in } \\
\text { Storage }\end{array}$ & $4-43$ \\
\hline $4-23$ & $\begin{array}{l}\text { Summary of Incremental Unit Costs at FWMS Facilities } \\
\text { Resulting From Acceptance of SNF in MESCs }\end{array}$ & $4-45$ \\
\hline $5-1$ & $\begin{array}{l}\text { Estimated Incremental Unit Costs to the FWMS } \\
\text { Resulting From Receipt of SNF In MESCs At A MRS } \\
\text { Facility }\end{array}$ & $5-2$ \\
\hline $5-2$ & $\begin{array}{l}\text { Estimated Incremental Unit Costs to the FWMS } \\
\text { Resulting From Receipt of SNF In MESCs At A } \\
\text { Repository }\end{array}$ & $5-3$ \\
\hline
\end{tabular}




\section{LIST OF FIGURES}

\begin{tabular}{clc} 
Figure No. & & \multicolumn{1}{c}{ Description } \\
\hline $3-1$ & & Diagram of Multiple Element Sealed Canister (MESC) \\
$3-2$ & Diagram of Horizontal Storage Module & $3-2$ \\
$3-3$ & Diagram of MESC Transfer Cask & $3-3$ \\
$3-4$ & Diagram of MESC Seal Welding System & $3-4$ \\
$3-5$ & Loading and Transfer of MESC to Horizontal Storage & $3-5$ \\
& Module & $3-6$ \\
$4-1$ & Processing Alternatives for MESCs in FWMS Facilities & $4-24$ \\
$4-2$ & ACD Facility Hot Cell Area & $4-27$ \\
$4-3$ & ACD Facility Spent Fuel Storage Cask & $4-29$ \\
$5-1$ & $\begin{array}{l}\text { Incremental Unit Costs to the FWMS Resulting } \\
\text { From The Receipt of SNF in MESCS As A Function of }\end{array}$ & $5-5$ \\
& the Amount of SNF So Received
\end{tabular}




\section{ACCEPTANCE OF SPENT NUCLEAR FUEL IN}

MULTIPLE ELEMENT SEALED CANISTERS BY THE

FEDERAL WASTE MANAGEMENT SYSTEM

\section{$1.0 \quad$ INTRODUCTION AND BACKGROUND}

The Standard Contract (1) between utilities and the Department of Energy (DOE) for the disposal of spent nuclear fuel (SNF) provides for the disposal of several categories of standard fuel, non-standard fuel, and failed fuel. Standard fuel is described in Appendix $E$ of the contract as being intact and non-defective PWR and BWR fuel assemblies that have had a minimum cooling time and which fall within an envelope of fixed maximum nominal dimensions. Included in the non-standard fuel category are fuel assemblies that exceed the fixed maximum dimensions, non-fuel components, fuel cooled less than 5 years, non-LWR fuel, and consolidated fuel rods. Included in the failed fuel category are fuel assemblies that exhibit visual failure or damage, radioactive leakage, and those that have been encapsulated previously. Basically all of the foregoing categories of SNF will be accepted by DOE for disposal purposes, however, all forms other than standard fuel may be subjected to delayed acceptance because of any special handling that might be involved therewith.

Separate from the Contract, the utilities have been considering alternative methods of storage of SNF at reactor sites. One of the alternative methods consists of storage of the spent fuel in a horizontal concrete module in which the fuel is contained within a special multipleelement sealed canister (MESC). The canister is placed in a transfer cask, filled with water, and lowered into the cask loading pool where the canister is loaded with fuel assemblies. After loading, a shielded end plug is placed on the canister, the transfer cask is lifted out of the pool, the water inside the cask and MESC is lowered from the MESC shielded end plug, and the plug is welded to the MESC. After all water has been removed from the MESC and it is backfilled with helium, a cover plate is placed on the MESC and welded in place. The transfer cask cover is bolted in place and the cask is placed on a trailer. The cask and contained MESC are then transferred to the horizontal concrete module where the MESC is pulled (or pushed) into the module. 
Subsequent to the execution of the Contracts, the question has been raised regarding whether or not a MESC containing spent fuel constitutes a fuel form that should be accepted by DOE. From a strict interpretation of the Contract provisions, DOE is only required to accept SNF which meets the general requirements set forth in Appendix $E$ thereto -. and this does not appear to include SNF contained in MESCs inasmuch as no mention of acceptance of aggregate units of fundamental fuel forms is included therein. This would appear to be reasonable inasmuch as theoretically a virtually endless number of aggregate configurations of the basic fuel forms might exist in at-reactor storage and it may be impractical to design to accommodate each of these configurations. It is to be expected that some configurations would not be able to be handled by the FWMS, while others could be handled at added cost and/or reduced throughput, and still others could be handled with little or no impact.

This question has been exacerbated somewhat as a result of the Nuclear Regulatory Commission (NRC) consideration of the prospective licensing of dry storage facilities at reactor locations, and NRC's apparent desire to achieve compatability and standardization between the utility spent fuel management systems and the FWMS (2).

Basically two different capacity MESCs have been selected for use by utilities in connection with the dry storage of spent fuel at reactor locations; one involves a 7 PWR assembly canister and the other involves a 24 PWR assembly canister. While many other capacities are possible, only these two have been proposed to date. Moreover, the 24 PWR assembly canister is probably the largest one that could be practically transported.

Since the Standard Contracts were executed, a number of issues have been identified regarding the waste acceptance criteria and scheduling of receipts of SNF by the FWMS that require clarification. The clarification of these issues may result in modifications to the standard contract or in establishing agreed-upon procedures for equitably dealing with them. In

FFundamental fuel forms refers to intact spent fuel assemblies, canisters of failed fuel, and canisters of consolidated fuel and non-fuel components having cross-sectional dimensions about the same as that of the intact fuel assemblies. 
order to support DOE's consideration of the possibility of acceptance of SNF from the utilities in MESCs, a study was conducted to estimate the cost and operational impacts on the FWMS as a result of receiving SNF assemblies in MESCS. It was recognized that DOE's acceptance of MESCS would result in benefits to the utilities using them for at-reactor storage including reduced fuel handling, reduced impact on reactor operations, reduced radiation exposure at reactor sites, and reduced utility costs. However, the study dealt only with impacts on the FWMS and did not attempt to estimate utility impacts. Moreover, the study:

(1) assumed that SNF would be consolidated in the FWMS, which was the basic DOE plan at the time the study was conducted,

(2) assumed that SNF contained in MESCs would be in the form of intact, non-defective fuel assemblies,

(3) assumed that only PWR fuel would be contained in MESCs inasmuch as current utility plans therefor only involve storage of PWR fuel,

(4) assumed that only 7 PWR assembly and 24 PWR assembly MESCS would be available for delivery to DOE,

(5) did not consider a contract category designation for SNF contained in MESCs,

(6) developed information that could be used to judge whether or not (and under what conditions) SNF delivered to DOE in MESCs could be accepted by DOE, and whether or not it could be accepted on the same scheduling basis as "standard fuel" as defined in the Standard Contract, and

(7) developed estimates of costs to the FWMS of receiving SNF in MESCs, and the number of significant figures used in the cost estimates are not intended to imply an accuracy greater than that normally associated with estimates.

This report describes the work performed during the study and the results obtained therefrom. Section 2.0 of this report presents a summary of the results of the work and the resulting conclusions. Section 3.0 describes the use of MESCs for at-reactor storage of SNF and current utility plans for use of MESCs for such storage. Section 4.0 presents an analysis of the impacts on the FWMS, including estimated costs, as a result of receipt of SNF in MESCs, and Section 5.0 presents a summary of these cost impacts. Estimates of life cycle costs for the FWMS that are associated with the receipt of SNF 
in MESCs are included in Appendices A through E. Section 6.0 describes the policy alternatives available to DOE regarding the acceptance of SNF in MESCs. Since the various cases analyzed regarding costs to the FWMS involved both different schedules and different amounts of SNF being handled by the systems, it was necessary to determine the unit costs for storage, transport and disposal so that a proper comparison could be made of the costs associated with the receipt of SNF in MESCS. The methodology used to calculate the unit cost is described in Appendix F. This unit cost (in 1988 dollars) is that which must be escalated at the inflation rate to the time of performance in order to effect full recovery of all costs involved in the operation. 
A study was made of the impacts on the Federal Waste Management System (FWMS) that would be caused by DOE acceptance of spent nuclear fuel (SNF) assemblies in multiple element sealed canisters (MESCS). Two different MESCs were considered -- a 24 PWR assembly MESC and a 7 PWR assembly MESC. The design modifications required and related operational and cost impacts of acceptance of PWR assemblies in MESCs were developed and compared to those involved in the receipt of individual PWR assemblies in a reference FWMS composed of shipping casks typical of those that have been ordered by DOE, and surface facilities at a MRS facility or repository that are represented by existing designs of such facilities. All of the impacts of receiving MESCS into the FWMS were assumed to be mitigated by the inclusion of additional facilities and equipment that would permit the FWMS to accept and handle MESCs therein without an adverse impact on its acceptance and handling of SNF assemblies. The costs for these additional facilities and operations were estimated and the added costs or savings resulting from the receipt of MESCs were determined. The following sections describe the impacts of receiving PWR assemblies in MESCS on the FWMS and summarize the incremental costs or savings associated therewith.

\subsection{IMPACTS ON FROM-REACTOR TRANSPORTATION}

With respect to impacts of acceptance of MESCs on from-reactor transportation activities, it was found that specially designed shipping casks would be necessary for the transport of MESCs inasmuch as:

- both types of MESCS were longer than the cavity length of the reference shipping casks

- the 24 PWR assemblies MESCs were larger in diameter than the cavity diameter of the reference shipping casks, and the 7 PWR assembly MESCs were much smaller in diameter.

Costs were estimated for shipping various quantities of SNF contained in MESCS, over distances of 500 miles and 2,800 miles, (nominally representing shipments to a MRS facility and a repository), under conditions where only MESCs were shipped. and where individual fuel assemblies were 
shipped in MESC casks to the extent no MESCs were available for shipment (to maximize the utilization of the cask). It was found that PWR assemblies contained in MESCs were generally more expensive to ship than individual PWR assemblies in the reference shipping cask. In the case of the 24 PWR assembly MESCs this increased cost varied from $\$ 2.40$ to $\$ 24 / \mathrm{kgl}$ depending on the distance, the total amount shipped (500-2,000 MTU), and whether maximum use was made of the cask. In the case of the 7 PWR assembly MESCs, this increased cost varied from $\$ 30$ to $\$ 450 / \mathrm{kgU}$ depending on the distance, the total amount shipped (50 - 250 MTU), and whether maximum use was made of the cask. These cost increases are primarily due to the need to procure a special cask for the MESCS and to charge the full cost thereof to the quantity of fuel shipped in MESCs. The much higher costs involved in shipping the 7 PWR assembiy MESCs was due to both the small amount of SNF expected to be in this form and the higher freight costs associated with the use of the smaller cask having a higher shipping cask weight per contained MTU.

It was concluded that the minimum operational impact on the FWMS would result if the MESC casks were used solely for MESC shipment.

\subsection{IMPACTS ON FWMS FACILITIES}

With respect to the impacts of acceptance of MESCS on the fixed-base facilities of the FWMS (MRS facility or repository), it was determined that the MESCs will have to be opened, and the empty MESCs disposed of, and that both these operations would be incremental to those associated with the receipt of individual PWR assemblies in a reference shipping cask. If the weld on the lid of the MESC is cut open while the MESC is in the shipping cask (or a transfer cask), the addition of hot cell space for MESC handling may be avoided. If a MRS facility is included in the FWMS, and the MESCs are received in time to be committed to interim storage there, the MESCs can be readily stored in vertical concrete casks with little modification to the existing designs of such casks. MESCs can also be stored in HSMs, in which case the MESCs can be transferred directly from the shipping cask to the HSM, however, special equipment will be required for such transfer and a transfer cask will be required later to retrieve the MESC.

The costs and operational impacts of a number of handling and processing scenarios were considered -- twenty-four different such scenarios 
were considered for the 24 PWR assembly MESCs, and eighteen scenarios were considered for the 7 PWR assembly MESCs. These scenarios included all reasonable combinations of the following:

- Total quantity of SNF received in MESCs -- ranging from 500 2,000 MTU for the 24 PWR assembly MESCs, and 50 - 250 MTU for the 7 PWR assembly MESCs

- No MRS facility in the FWMS, and a FWMS which included a MRS facility

- Cutting the welds on the MESC lid outside of the hot cell facilities followed by unloading the contained assemblies into the hot cell, or, alternatively, unloading the MESC into the hot cell and cutting the welds and unloading the assemblies therein, and

- Storage of MESCs in concrete casks and horizontal storage modules (HSM) at the MRS facility, or immediately opening and unloading the MESCs.

All of the scenarios assumed that the MESC would be acceptable to NRC for shipment after the at-reactor storage period.

Incremental life cycle costs were calculated for each of the scenarios considered and the incremental unit costs resulting from the acceptance of MESCs by FWMS facilities were determined. As a result of the foregoing, it was found that the receipt of PWR assemblies in MESCs is more expensive to the FWMS facilities than the receipt of individual PWR assemblies, but that this cost can be minimized by cutting the weld on the MESC lid while it is in the shipping cask (or a transfer cask), thus avoiding the high additional cost of adding hot cell facility space for this operation and the attendant operating costs. However, in cases where the 24 PWR assembly MESCs are received in time to be stored at MRS facilities, the savings associated with storage in HSMs more than offsets the added costs involved in opening the MESCs and disposing of them once they have been unloaded.

\subsection{SUMMARY OF ESTIMATED INCREMENTAL UNIT COSTS OR SAVINGS}

The estimated incremental unit costs or savings associated with the receipt of PWR assemblies in MESCS by the FWMS are shown in Tables 2-1 and 2-2. 
TABLE 2-1

ESTIMATED INCREMENTAL UNIT COSTS (OR SAVINGS) TO THE FWMS RESULTING FROM RECEIPT OF SNF IN MESCS AT A MRS FACILITY

(1988 Dollars)

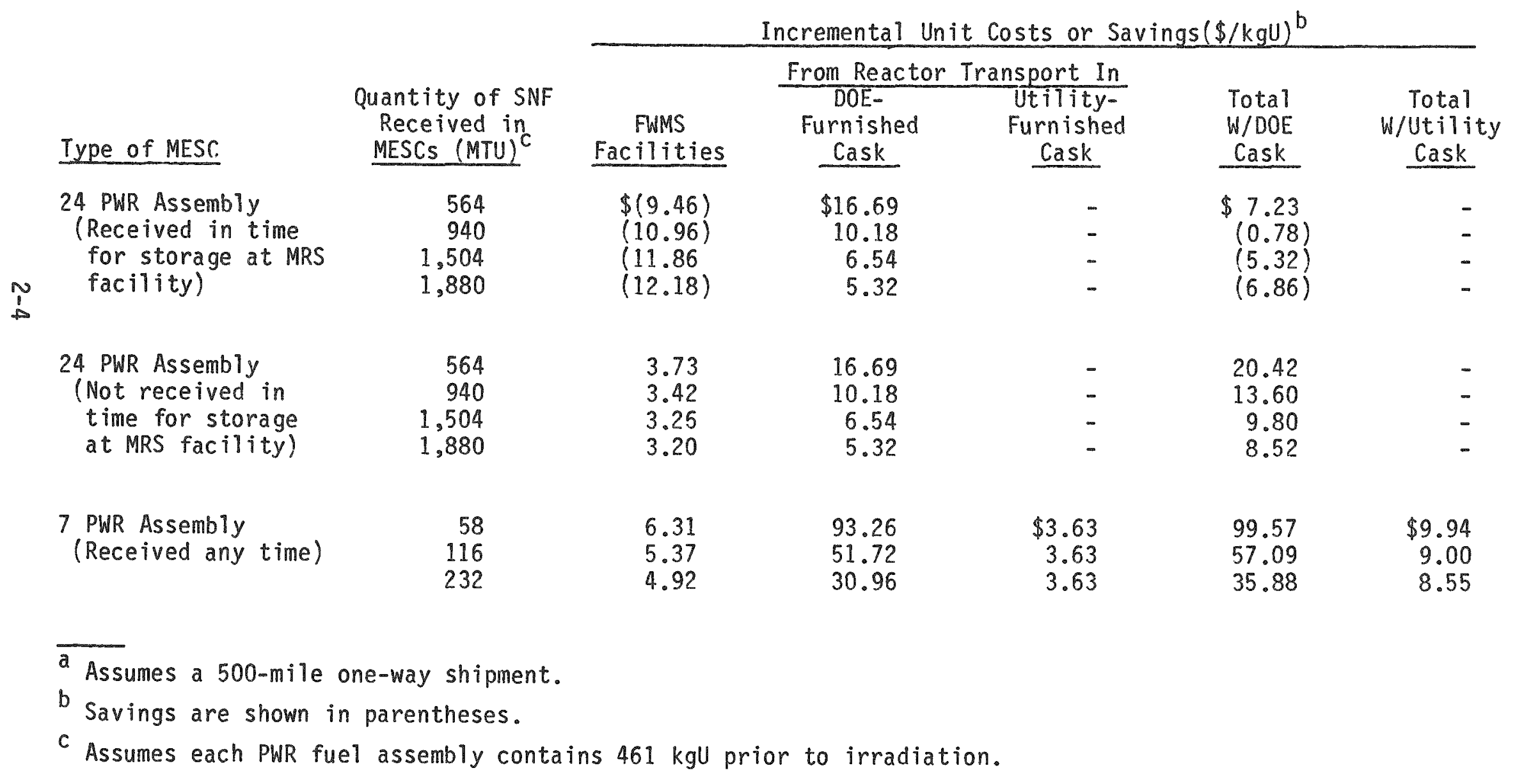


TABLE 2-2

ESTIMATED INCREMENTAL UNIT COSTS (OR SAVINGS) TO THE FUMS RESULTING FROM RECEIPT OF SNF IN MESCS AT A REPOSITORY ${ }^{a}$

(2988 Dollars)

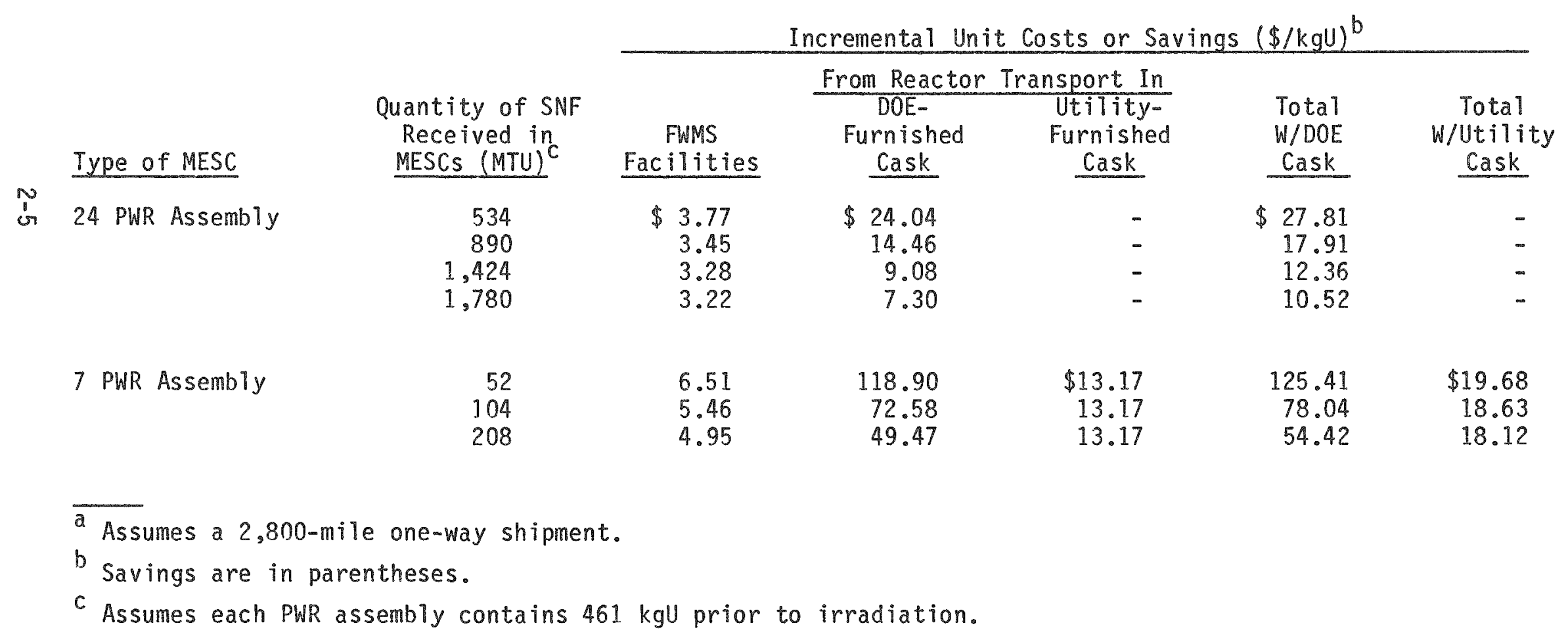


These incremental unit costs are those resulting from the use of special MESC shipping casks that are incremental to the presently planned DOE fleet and are used exclusively for shipment of MESCs - and the use of the most economical scenarios considered during the course of the study for handling of MESCs in the FWMS facilities. From the cost data shown in the tables it can be seen that receipt of SNF in MESCs into the FWMS results in cost increases over those which would have been otherwise incurred had the SNF been received in the form of individual PWR assemblies--except where 900 MTU or more of SNF was received in 24. PWR assembly MESCs in time to store it in MRS facilities (2005 or thereabouts). In all cases, the cost of from-reactor transport is higher as a result of the need to add special-purpose cask(s) to the DOE fleet. However, in the limited instances cited above (where 900 MTU or more of SNF was received in 24 PWR assembly MESCs early enough to commit it to storage in the MRS facility), the cost savings resulting from the use of low cost HSMs more than offset the added cost of shipment.

Extrapolating the incremental unit costs (or savings) shown in the tables for the 24 PWR assembly MESCs to those applicable to 10,000 MTU, indicate that

- savings for MESCs received in time to be stored at the MRS facility would increase to about $\$ 13 / \mathrm{kgU}$

- added costs for MESCs otherwise received at the MRS facility would decrease to $\$ 5-6 / \mathrm{kgU}$

- added costs for MESCs received at the repository would decrease to about $\$ 6 / \mathrm{kgU}$.

\subsection{THE ISSUE OF MESC ACCEPTANCE}

There are several policy alternatives that might be followed by DOE in dealing with the prospective acceptance of SNF in MESCs for transport and disposal. The DOE could either decline to accept SNF in such a form (package) or it could agree to accept it. If it agreed to accept MESCs, it could either do so without charge or it could charge for the added costs (or credit for avoided costs) to the FWMS resulting from such acceptance. The basic issues that must be addressed arise because the acceptance of MESCs may directly increase FWMS costs, and hence the collective costs shared by all utilities. 
Further, such cost increases are at the discretion of the individual utility delivering the MESCS, which has the viable alternative of delivering fuel assemblies. The discretionary nature of this cost increase directly raises the issue of inter-utility equity, and the three alternatives deal with this issue in the following ways:

(1) DOE declines to accept MESCs. This approach avoids the issue of inter-utility equity by foreclosing the possibility of incurring MESC-related cost increases in the FWMS.

(2) DOE accepts MESCs without charge for added costs or credits for avoided costs. This approach implicitly accepts and tolerates any inter-utility inequity that may be incurred.

(3) DOE accepts MESCs with payment for added costs (or provides credits for avoided costs). This approach avoids interutility inequities by charging or crediting the full amount of the increases or decreases in costs that are incurred thereby.

Section 6.0 of this report lists the technical conditions under which MESCs could be accepted by the FWMS and provides a mechanism for charging (or crediting) utilities for the incremental costs or savings to the FWMS resulting from acceptance of MESCS. 
This section describes the use of MESCs for at-reactor storage of SNF and the current utility plans for such use.

DESCRIPTION OF THE USE OF MESCS FOR AT-REACTOR STORAGE

MESCs are cylindrical stainless steel canisters, which are shielded at both the top and bottom with lead. SNF assemblies are loaded into guide sleeves that are positioned in the cavity of the MESC, and which form a part of its internal basket structure. Once the MESC has been loaded with SNF assemblies, the internal cavity is drained, dried, and purged with helium -. after which the top shield plug and top cover plate are seal welded. A diagram of the loaded MESC is shown in Figure 3-1.

HSMs are concrete structures into which loaded MESCs are inserted for storage in a horizontal configuration. The HSMS provide cooling of the MESC by natural air convection, and radiological shielding. The MESCs are loaded into openings in the front of the HSM, and the opening is closed with a shielded door. A diagram of the loaded HSM is shown in Figure 3-2.

Loaded MESCs are moved from the reactor pool to the HSM using a metal transfer cask, such as that shown in Figure 3-3.

The following summarizes the basic operations involved with the use of MESCs and HSMS for at-reactor storage:

(1) The empty MESC is loaded into the transfer cask and the latter is lowered into the cask loading pool.

(2) SNF assemblies are loaded into the MESC while it is positioned under water in the transfer cask, and the top shield plug is inserted into the MESC.

(3) The transfer cask is removed from the pool and placed in the cask decontamination pit where it and the roaded MESC is drained, dried, inerted, and the top shield plug of the MESC is seal welded. The top cover plate is then seal welded over the shield plug. A diagram of the seal welding operation is shown. in Figure 3-4.

(4) The transfer cask is loaded onto a trailer and moved to the HSM location where the MESC is inserted into the HSM using either a ram to push it from the cask into the HSM or one that pulls it in from the cask, depending on the design of the individual installation.

The foregoing operations are shown in Figure 3-5. 


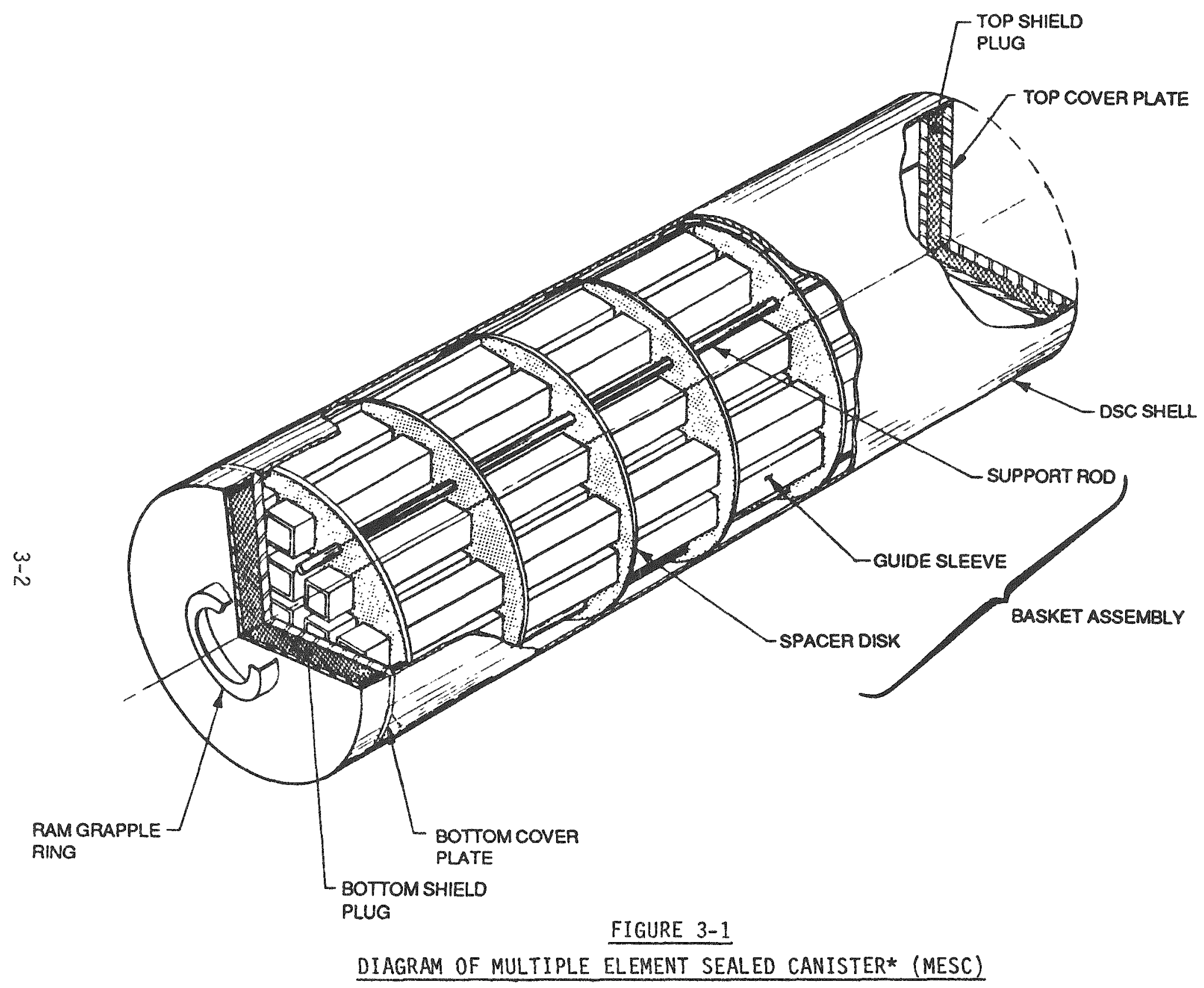

-Courtesy NUTECH, Inc.

*Multiple-element sealed canisters (MESCS) and dry storage canisters (DSCS) are synonomous. 


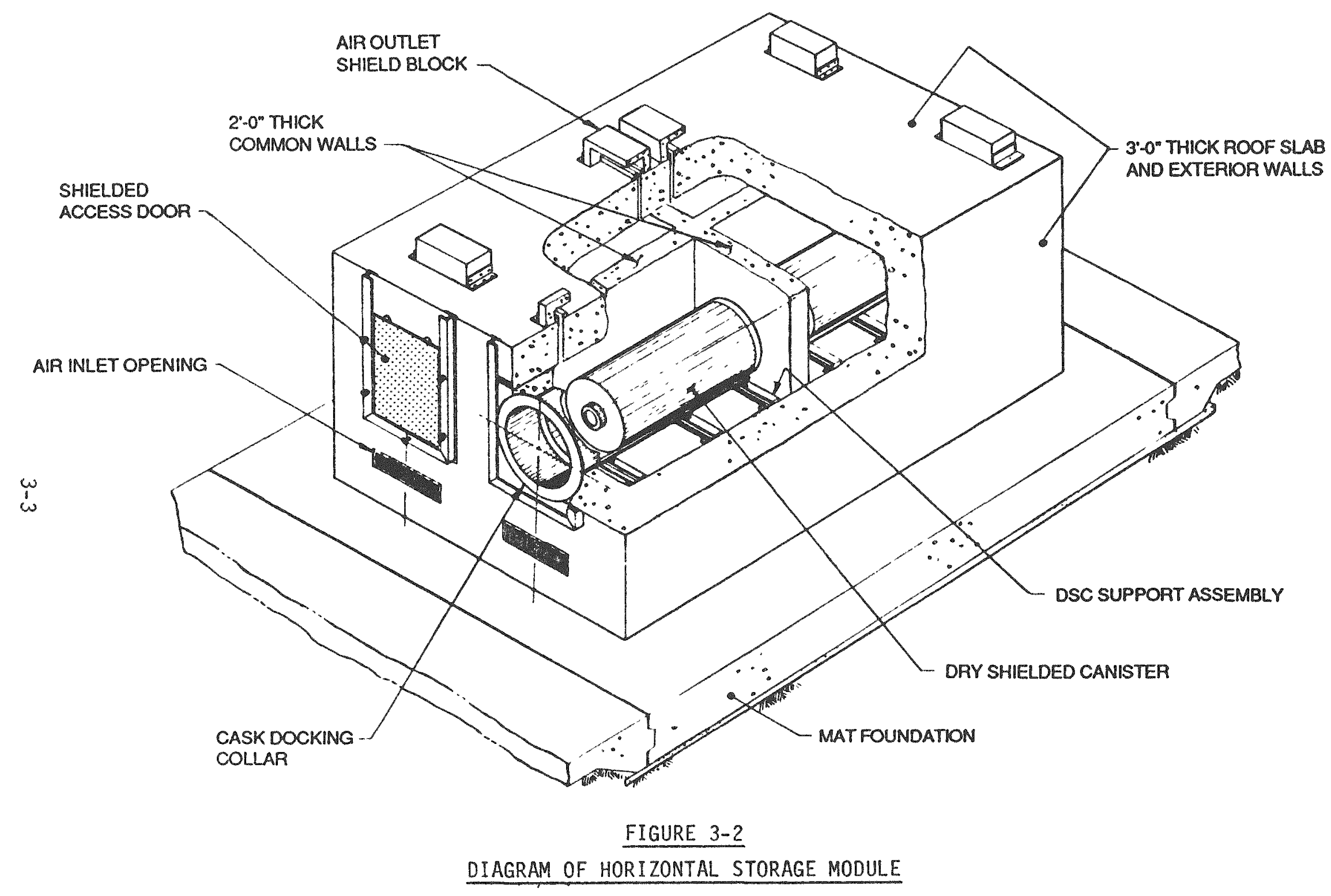

-Courtesy NUTECH, Inc. 


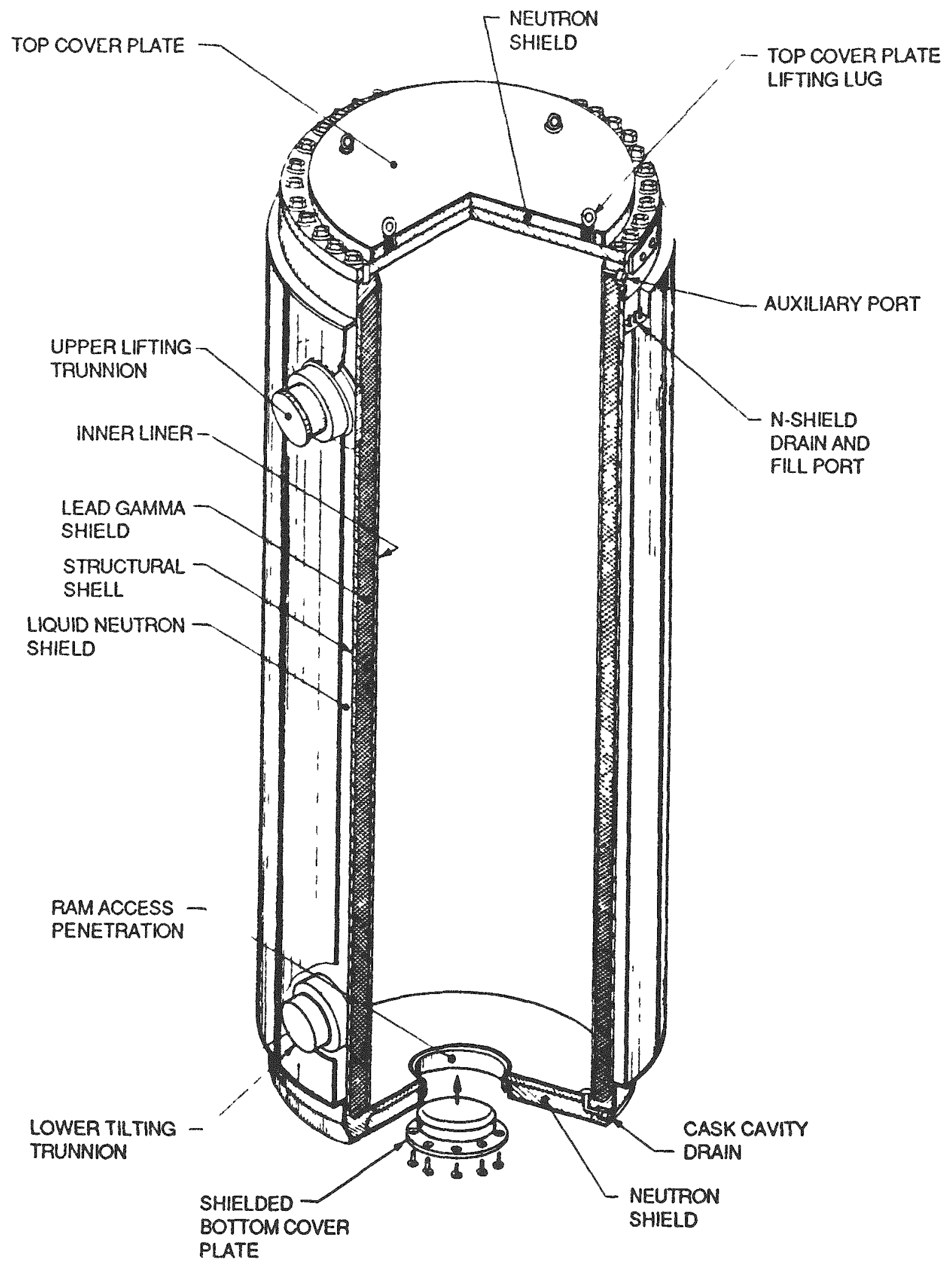

FIGURE $3-3$

DIAGRAM OF MESC TRANSFER CASK

-CourtesY NUTECH, Inc. 

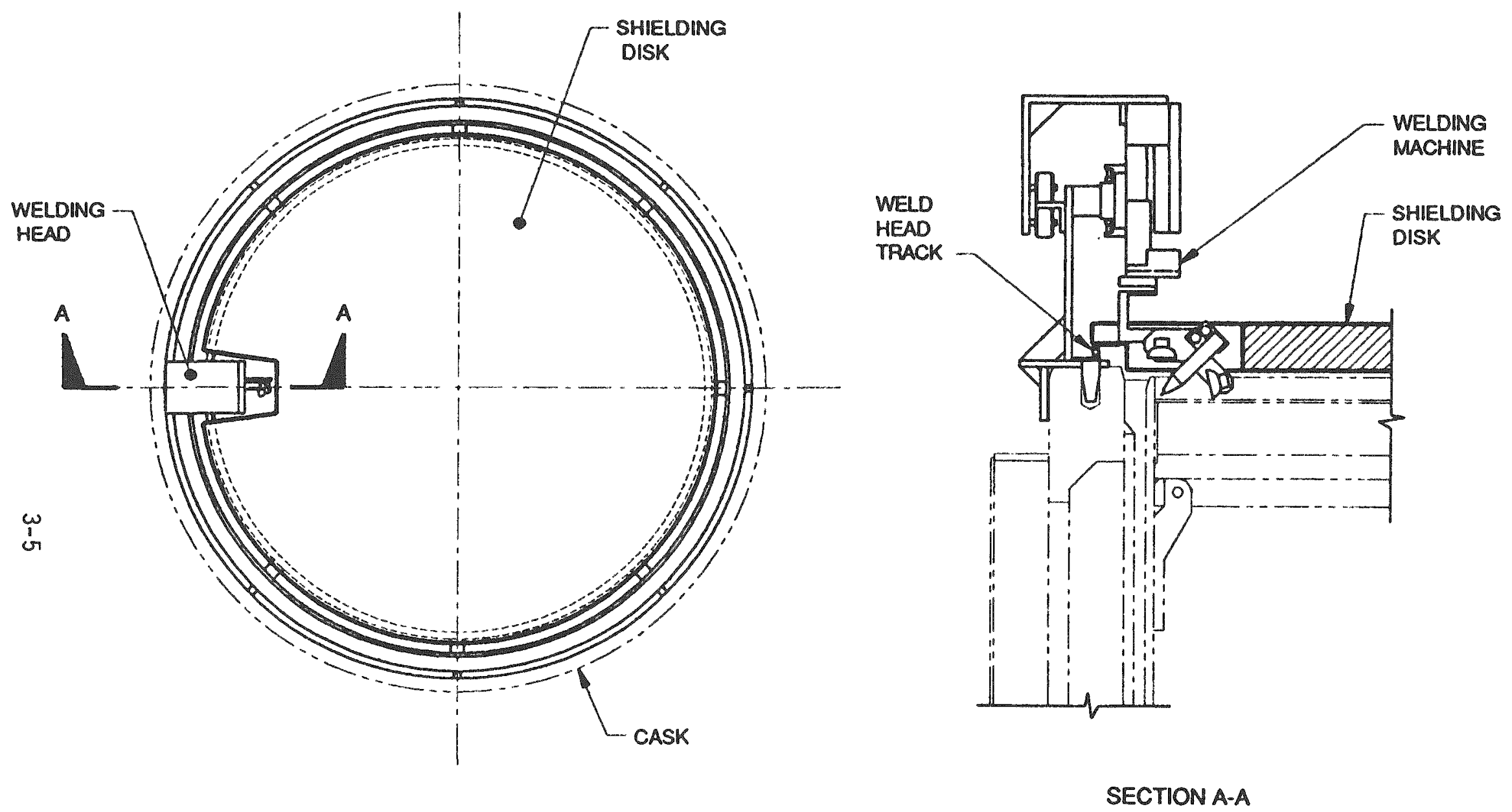

FIGURE $3-4$

DIAGRAM OF MESC SEAL WELDING SYSTEM 

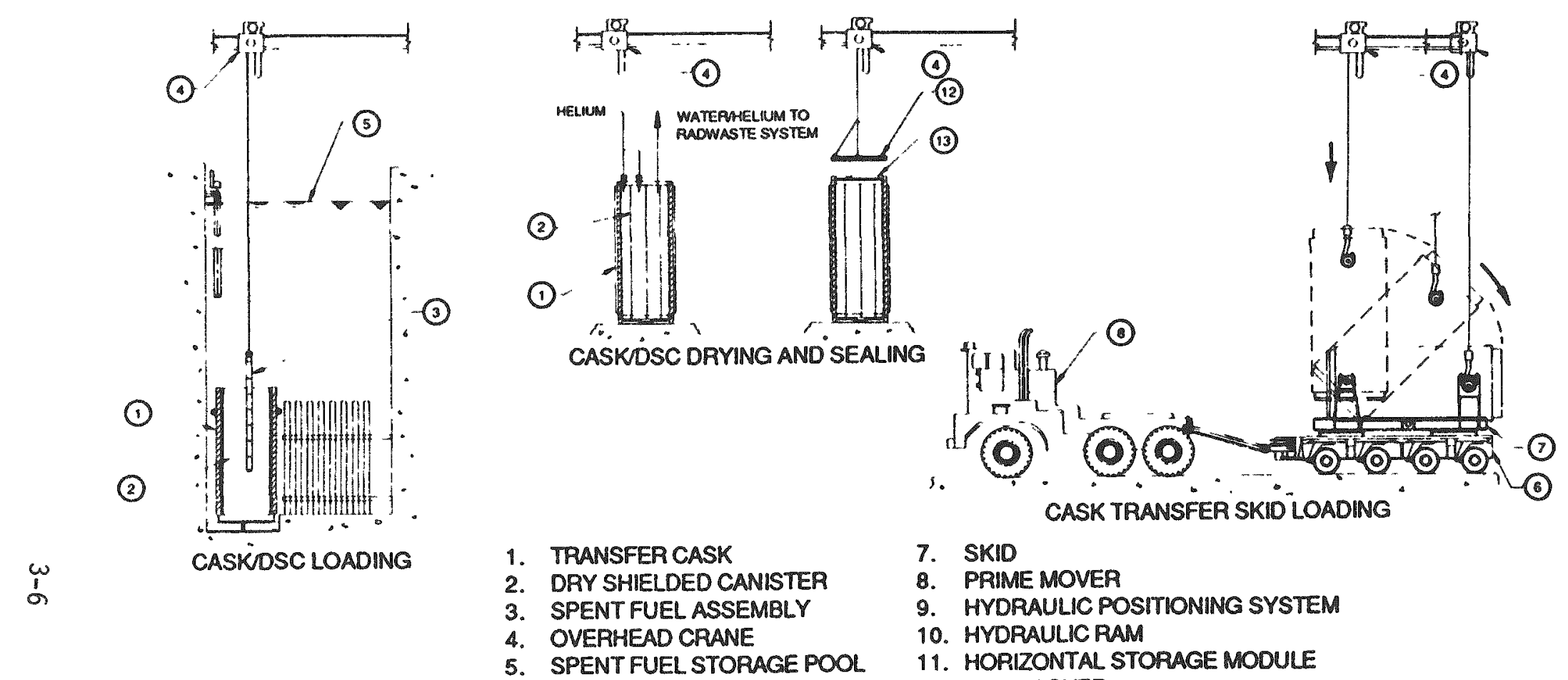

1. TRANSFER CASK

2. DRY SHIELDED CANISTER

7. SKID

3. SPENT FUEL ASSEMBLY

8. PRIME MOVER

4. OVERHEAD CRANE

5. SPENT FUEL STORAGE POOL

6. TRANSPORT TRAILER

9. HYDRAULIC POSITIONING SYSTEM

10. HYDRAULIC RAM

11. HORIZONTAL STORAGE MOOULE

12. CASK COVER
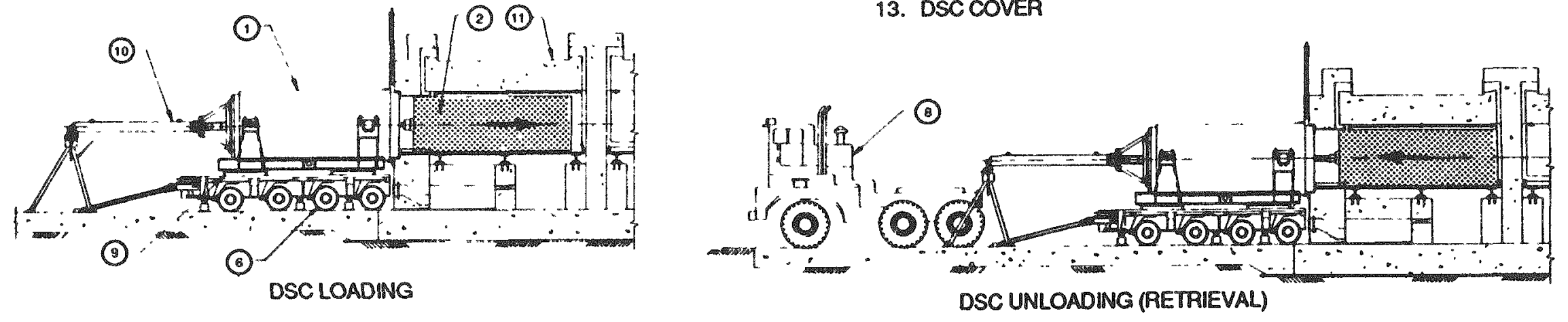

FIGURE $3-5$

LOADING AND TRANSFER OF MESC TO HORIZONTAL STORAGE MODULE 
Removal of the MESC from storage, and removal of the SNF assemblies from the MESC, is accomplished by reversing the above-described procedure -onty in this instance, a cutting tool is used on the apparatus shown in Figure 3-4 instead of a welding device. It is also possible that a DOE-supplied shipping cask could be loaded with a MESC directly from the HSM, should DOE agree to accept SNF in MESCs, thus eliminating the need to open the MESC at the reactor and transfer the SNF to a shipping cask.

To date, only two principal types of MESCs are planned for use by utilities; a 24-PWR assembly MESC and a 7-PWR assembly MESC, although other types are possible. However, the 7-PWR assembly MESC is being used principally to demonstrate the technology and is not expected to be used elsewhere. The 24-PWR assembly MESC is probably the design that is most likely to be used for any widespread at-reactor storage application.

\subsection{PLANS FOR USE OF MESCS BY UTILITIES}

As of the Spring of 1989, three utilities have announced plans to use horizontal concrete modules and their associated MESCs for supplemental at reactor storage.

(1) Carolina Power \& Light Co. (CP\&L) is involved in a demonstration program with DOE and others at its $H . B$. Robinson reactor site in which MESCs having a capacity for 7 PWR assemblies will be used. This demonstration commenced in the spring of 1989, and will involve the storage of 21 PWR assemblies $(3,4)$. The MESC design to be used in the CP\&L facilities is 37 inches in diameter, 179 inches long, and weighs $22,000 \mathrm{lb}$ loaded (about 12,000 1b empty). CP\&L is licensed to store up to 56 PWR assemblies at $H$. B. Robinson and may add more such storage modules there and at its Brunswick plant if the need therefor arises $(2,8)$.

(2) Duke Power Company (Duke) plans to use this method of dry storage at its Oconee Station using MESCs having a capacity for 24 PWR assemblies. This storage activity is scheduled to commence in 1990, and Duke has requested NRC authorization to store up to 2112 PWR assemblies in this fashion $(5,6,7)$. Duke plans to store 168 PWR assemblies in 1990, 144 PWR assemblies in 1991, and 96-120 PWR assemblies every year thereafter unti1 the authorized capacity of 2112 PWR assemblies has been reached (8). This means that additions to storage will be made at least through the year 2008. The MESC design to be used in the Duke facilities is nominal1y 66.5 inches in diameter, 186 inches long and weighs $80,000 \mathrm{1b}$ loaded (about 45,000 1b empty). 
(3) Baltimore Gas \& Electric (BG\&E) plans to use this method of dry storage at its Calvert Cliffs Station (9) using a MESC essentially identical to the one to be used by Duke (2), except it is 173 inches long. BG\&E plans to store 576 PWR assemblies commencing in 1991 and 192 PWR assemblies every other year thereafter until DOE accepts spent fuel (8). This means that the total amount committed to such storage could be as much as that planned for storage by Duke.

In addition, other utilities have indicated an interest in this method of storage although no known commitments therefor have been made as of mid-1989. However, based on existing plans it can be expected that as much as 2000 MTU as SNF will be stored in 24 PWR assembly MESCs and as 1 ittle as 25 MTU as SNF will be stored in 7 PWR assembly MESCs.

No particular interest has been evidenced to date regarding the storage of consolidated SNF in MESCs. This is probably due to the fact that the cost of consolidation may well exceed the savings that result from storing consolidated SNF in MESCS/HSMS. 
4.0 IMPACTS OF ACCEPTANCE OF SNF IN MESCS ON THE FWMS

A review was conducted of each operation in which a MESC would likely be involved in the FWMS and the impact that it would have on each portion of the system. The results of this review are described in the following sections.

\subsection{IMPACTS ON FROM-REACTOR SHIPPING}

This section reports the resuits of the study of the impacts and costs associated with the acceptance of MESCs on the transport of spent fuel from reactors to DOE facilities.

\subsubsection{Analysis of Impacts on Shipments}

The DOE has contracted with three organizations for the development of rail-type shipping casks for SNF. The preliminary capacities, cavity dimensions and weights of these casks are described in Table 4-1.

TABLE 4-?

FROM-REACTOR SNF SHIPPING CASK CAPACITIES, OIMENSIONS \& WEIGHTS

\section{Contractor}

Nuclear Assurance Corp. (NAC)

Nuclear Packaging (NUPAC)

Babcock \&ilcox (B\&)

$\overline{a_{\text {Without impact }} \text { limiter }}$

\begin{tabular}{cc} 
Cask Capacity & (Assys) \\
\hline$\frac{P W R}{26}$ & $\underline{B W R}$ \\
21 & 52 \\
16 & 48 \\
& 40
\end{tabular}

\begin{tabular}{cc}
\multicolumn{2}{c}{ Cavity Dimensions (in) } \\
Diameter & Length \\
66 & 178 \\
55 & 178 \\
64 & 180
\end{tabular}

Cask Weights (tons)

Empty Lozded

$78 \quad 100$

80.597

$73 \quad 98.5$

From the data shown in the table it can be seen that none of the casks has a cavity that is sufficiently large to accommodate a 24 PWR assembly MESC (see MESC dimensions in Section 3.2). This means that a larger cask would be needed to transport the 24 PWR assembiy MESC. On the other hand, the data shows that these casks have a considerably larger diameter than the 7 PWR 
assembly MESC, and, in the case of two of the casks, the cavities thereof are slightly shorter than the length of the 7 PWR assembly MESC. This means that a smaller diameter cask having a slightly longer cavity length would be needed to transport a single 7 PWR assembly MESC efficiently, or that a larger diameter cask having a slightly longer cavity length would be required to transport two 7 PWR assembly MESCs.

ATl three such MESC cask designs were considered in this study and conceptual designs were developed for each. It was recognized that in order to obtain efficient utilization of the MESC casks it might be necessary to be able to ship spent fuel assemblies in the cask as well as MESCs. Therefore, the design of the MESC casks included the alternative of having a removable assembly basket. The basic characteristics of these casks are described in Table 4-2.

TABLE 4-2

CONCEPTUAL CHARACTERISTICS OF MESC SHIPPING CASKS ${ }^{a}$

Payload Capacity No. Assemblies MTU

Qverall Dimensions Diameter (in.) Length (in)

Cavity Dimensions

Diameter (in.) Length (in)

Weight On Transport Vehicle (tons) Loaded with Assemblies Loaded with MESC Empty with Assembiy Basket Empty w/o Basket

Weight on Reactor Crane Hook (tons) Loaded with Assemblies Loaded with MESC Empty with Assembly Basket Empty w/o Basket
24 PWR

As sembly

MESC Cask

24

11.06

92

208

67

187

131

145

113

105

113

127

95

87

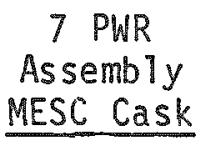

7

3.23

63

200

101

200

76

180

38
180

143

142

125

120

61

57

60

40

49
123

121

104

99

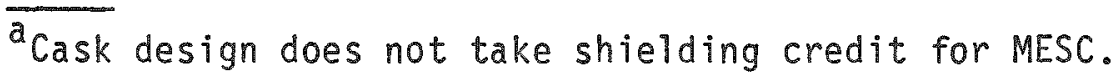

${ }^{b}$ Figures in parentheses appiy to shipments of uncanistered SNF assemblies. 
It is apparent from the weights shown in the above table that a reactor site which intends to handle a 24 PWR assembly MESC and shipping cask in the reactor pool will have to have a lifting capability of about 130 tons. Alternatively, the cask might be loaded directly from the HSM used for storage.

\subsubsection{Estimates of Transportation-Related Cost Impacts}

The cost impacts of incorporating MESC shipping casks into the DOE cask fleet were estimated and are described in this section. This includes a review of the costs associated with the cask fleet planned for use in transporting spent fuel assemblies, estimates of costs of MESC casks and those costs associated with the use of the MESC casks, and a comparison of the life cycle costs and unit costs for transportation of spent fuel in a "standard" or reference assembly shipping cask and in MESC casks. For the purposes of this study the NUPAC rail cask was selected as the reference shipping cask inasmuch as both its capacity and cost were in the mid-range of all of the prototype rail casks contracted for by DOE.

\subsubsection{Estimated Cost of the Reference Shipping Cask}

The contract for the two shipping casks entered into between DOE and NUPAC amounted to $\$ 13.591-m i 11$ ion, broken down as follows:

TABLE $4-3$ COST OF REFERENCE SHIPPING CASK

Description

Design \& Development

Model Fabrication

Model - Engineering, Design Verification

Testing, Management and Admin, and QA

Prototype Fabrication (2 casks)

Prototype - Acceptance Testing, Performance Evaluation, Support to DOE, Management and Admin, and $Q A$

Total

\begin{tabular}{|c|c|c|c|}
\hline 1987 & Dollars & 1988 & Dollars \\
\hline \multirow[t]{5}{*}{$\$$} & 3,770 & $\$$ & 3,906 \\
\hline & 837 & & 861 \\
\hline & 1,184 & & 1,227 \\
\hline & 6,421 & & 6,602 \\
\hline & 1,379 & & 1,429 \\
\hline$\$$ & 3,591 & & 14,025 \\
\hline
\end{tabular}

a Fabrication costs escalated by $3.6 \%$ (based on changes to the Machinery and Equipment Index). Other costs, essentially all labor related, escalated by $2.82 \%$ (based on changes to labor rates for Production Workers on NonAgricultural Payrolls). 
The foregoing costs were estimates used in developing a cost-plusfixed-fee contract for the casks and did not include the cost of NRC certification fees.

\subsubsection{Estimated Cost of MESC Shipping Casks}

The cavity size of the NUPAC rail cask was about 178 inches long by about 55 inches in diameter. This is a little short to be able to accommodate the MESCS (the H.B. Robinson MESC is 179 inches long and the Oconee MESC is 186 inches long). Also, the diameter for the NUPAC cask is clearly too small to accommodate the Oconee MESC (67 inches in diameter), while it is much too large to efficiently accommodate the 37-inch diameter H. B. Robinson MESC and too small to accommodate two such MESCs (requiring a 75-inch cavity diameter).

Therefore, the costs of three different sized MESC shipping casks were estimated, including casks capable of transporting (i) one 24 PWR assembly MESC, (ii) one 7 PWR assembly MESC, and (iii) two 7 PWR assembly MESCs. These costs included the cost of:

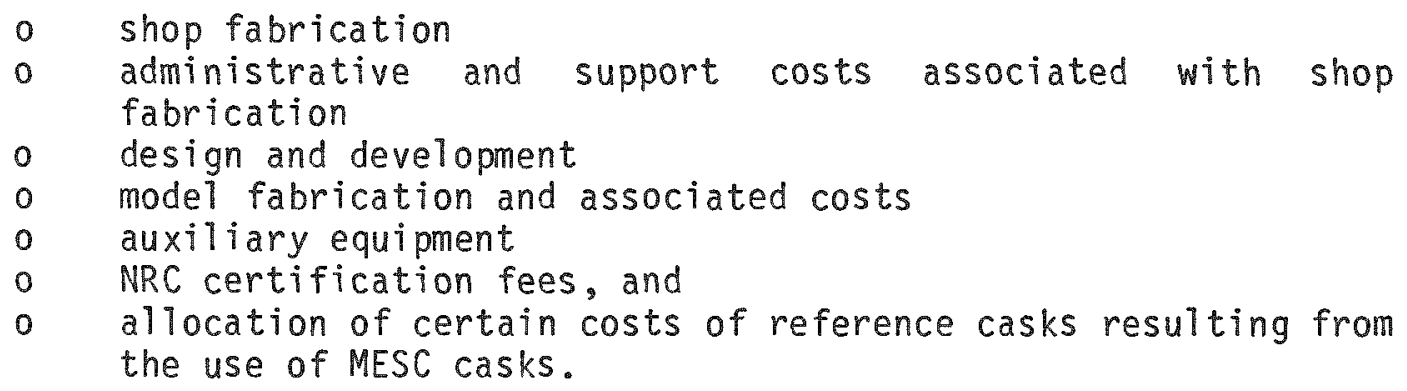

A summary of these costs is set forth in Table 4-4; the derivation of the costs contained in the table is described in the remainder of this section.

In the cases involving casks for shipping single MESCs, it was assumed that the MESC would serve as the cask basket. In the case of the $2 / 7$ PWR assemb1y MESC cask, it was assumed that a MESC basket would be required. Furthermore, it was assumed that an assembly basket might be required for the MESC casks for instances in which there was an insufficient number of MESCs available for efficient cask utilization. 
TABLE 4-A

SUMGARY gREAKDOWN OF TOTAL PER CASK COST OF REFERENCE SHIPPIMG CASKS AMO MESC SHIPPIMG CASKS

$1000.1988)$

\begin{tabular}{|c|c|c|c|c|c|c|c|c|c|c|c|c|c|c|c|c|c|c|}
\hline \multirow[b]{3}{*}{ Descriprian } & \multirow{2}{*}{\multicolumn{2}{|c|}{$\begin{array}{l}\text { Reference MUPAC } \\
\text { Shipoing Cost } \\
\end{array}$}} & \multicolumn{6}{|c|}{24 PUR Assenbly HESC Shigping Cask } & \multicolumn{4}{|c|}{7 PMR Asseabiy MESC Shipplan Cask } & \multicolumn{6}{|c|}{ 2/7 PUR Assembly MESC shipping Cask } \\
\hline & & & & hout Bask & & & Ien Basker & & sithou & Oasket & wien & dasker & & hout Bask & & & Both Bas & \\
\hline & 2 Casks & 10 Casks & 1 Eask & 2 Casks & 3 Casks & 1 Cask & 2 Cosks & 3 Cosks & 1 Cask & 2 Coskz & 1 Cosk & $2 \cos k s$ & 1 Cosk & 2 Casks & 3 Casks & 1 Cask & 2 Casks & 3 Cosks \\
\hline Design \& Developsent & $\$ 1,953$ & $\$ 390$ & 547 & $\$ 274$ & $\& 182$ & 781 & 391 & 1260 & $\$ 587$ & 274 & 8781 & 391 & $\& 781$ & \& 391 & $\$ 260$ & $\$ 9.016$ & $\$ 508$ & $\$ 339$ \\
\hline 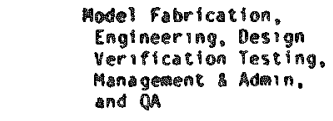 & 1.044 & 209 & 2.559 & 1.280 & 853 & 2.559 & 1.280 & 853 & a & A & a & a & b & b & b & 0 & b & b \\
\hline Cask Fabrication & 3.301 & 2.790 & 3.741 & 3.030 & 2.794 & 4.819 & 3.999 & 3.726 & 2.686 & 2.046 & 3.231 & 2.482 & 4.383 & 3.565 & 3.292 & 5,900 & 4.972 & 4.663 \\
\hline $\begin{array}{l}\text { Accegtance Testing, } \\
\text { Performance Eval.. } \\
\text { Support to DOE. } \\
\text { Management \& Adimin. } \\
\text { and OA }\end{array}$ & 715 & 558 & 812 & 634 & 575 & 970 & 758 & 688 & 671 & 525 & 829 & 648 & 823 & 690 & 626 & 1.095 & 857 & $m 7$ \\
\hline Auxiliary Equiranent & 668 & 664 & 664 & 664 & 664 & 664 & 664 & 664 & 664 & 664 & 664 & 664 & 664 & 664 & 664 & 664 & 664 & 664 \\
\hline MaC Certufication Fee & 83 & 16 & 165 & 83 & 55 & 165 & 83 & 55 & a & a & - & a & b & - & - & $b$ & b & b \\
\hline $\begin{array}{l}\text { Allocartion of Added } \\
\text { Cost } \mathcal{E}^{f} \text { Reference }\end{array}$ & M/A & W/A & 896 & 996 & 896 & 896 & 896 & 896 & 261 & 261 & 261 & 261 & 971 & 971 & 971 & 971 & 971 & 971 \\
\hline Totol $\cos t$ of Cosk & 27.960 & 14.623 & 29.389 & 96.862 & $\$ 6,019$ & 110,854 & 39.071 & 2,102 & 8929 & $\$ 3.770$ & 35,786 & $\$ \$ \$ A, 846$ & $\$ 2,682$ & 85.281 & 85,813 & 19,646 & 22.972 & 22.414 \\
\hline
\end{tabular}

Covered by the cosis for the reference shipping cask.

- Covered by the costs for the 2A PU⿴囗十⺝ assembly MESC cask.

- Allocation to MESC casks of added costs for reference casks resulting from fewer reference easts beting procured. 
The method of estimating the cost of the MESC casks as shown in

Table $4-4$ is described by the following:

\section{(1) Fabrication of the Casks}

Since no detailed breakdown of the costs for the NUPAC rail cask were publicly available, independent estimates of these costs were made during the course of this study. The difference between the costs estimated in this study and those in Section 4.1.2.1 was taken as a contingency associated with the cask fabrication cost estimate. Using this information as a base, the cost of NUPAC-type casks having different diameters and lengths from that of the reference cask were estimated. A summary of the estimated costs developed in this study for fabrication of the reference NUPAC cask, and NUPAC casks modified for shipment of MESCs, is set forth in Table 4-5.

The labor, materials and utilities costs were those estimated during the course of this study: labor costs included a 35 percent labor burden and an allowance for 50 percent efficiency due to scheduling; materials costs included allowances for fabrication losses. Overhead and G\&A (general and administrative) were taken as being 100 percent of labor costs and 10 percent of the cost of materials and special equipment. The cost of fabrication facilities was estimated during the study as was the utilization efficiency thereof; depreciation was calculated on a 10-year straight-line basis assuming a 50 percent utilization efficiency. Property taxes and insurance were calculated on the bas is of $\$ 1 / \$ 100$ valuation assuming a 50 percent utilization efficiency. Pre-tax profit was calculated on the basis that the fabricator would require a 17 percent discounted cash flow after-tax return on its investment in the fabrication facilities used, and assumed a 46 percent Federal Tax rate, a 6 percent State tax rate, and a 50 percent facility utilization efficiency. The cost of special equipment was estimated during the study.

Using the foregoing methodology, it was determined that the fabrication costs so calculated for the two prototype NUPAC rail casks were about 29 percent less than the estimated costs under the contract between DOE and NUPAC. This was assumed to be the contingency associated with cask fabrication, and this same contingency percentage was used for the MESC casks as we11. The total costs were then increased by 2.82 percent to escalate them to 1988 dollars.

The estimated cost of fabricating multiple numbers of casks was calculated by spreading the cost of special equipment over the numbers of casks involved. This produced multiple cask fabrication costs as shown in Table 4-6. 
TABLE 4-5

ESTIMATEO FABRICATION COST OF FROM-REACTOR SNF SHIPPING CASKS

$(\$ 000)$

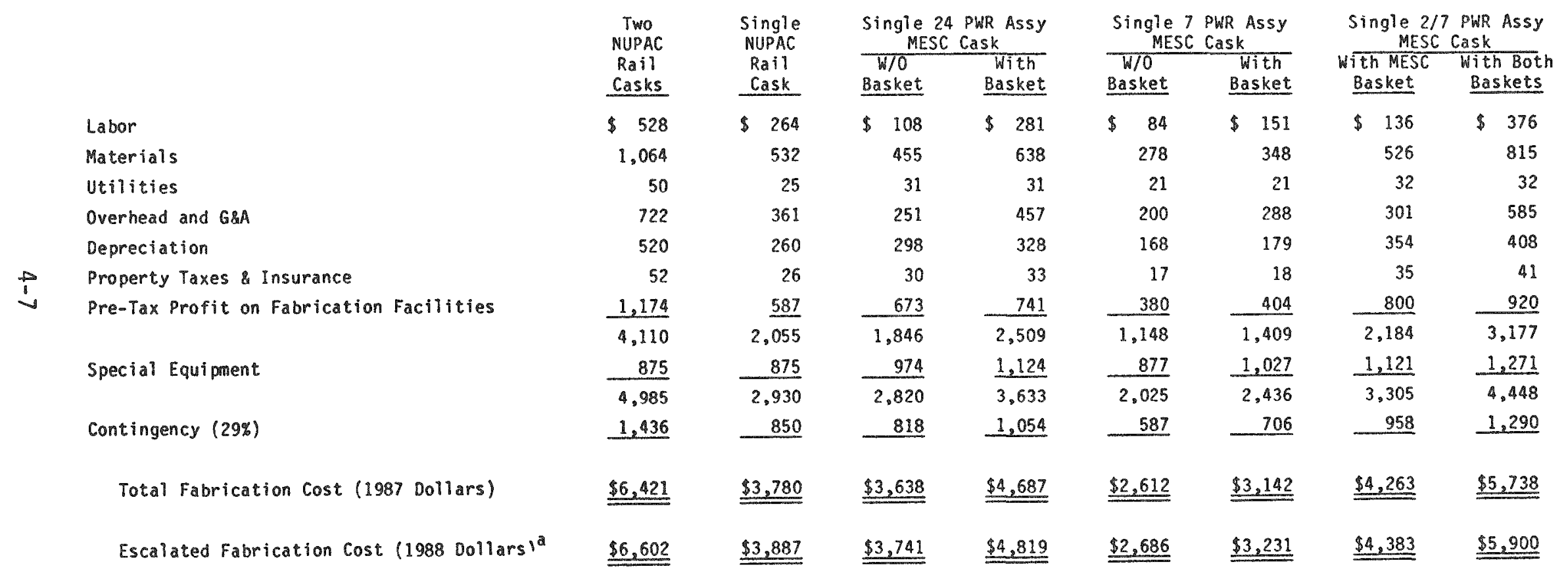

$\overline{a_{\text {Escalated }}}$ from 1987 to 1988 dollars using Machinery and Equipment Index (1.0282) 
TABLE 4-6

ESTIMATED FABRICATION COST OF SNF SHIPPING CASKS

AS A FUNCTION OF THE NUMBER OF CASKS BUILT

$(\$ 000,1988)$

Cost Per Cask For Indicated Number of Casks Built

\section{Cask Type}

Reference NUPAC Shipping Cask

24 PWR Assembly MESC Cask

W/O Basket

With Basket

7 PWR Assembly MESC Cask

W/0 Basket

With Basket

2/7 PWR Assembly MESC Cask

W/MESC Basket

W/Both Baskets

2 Casks 3 Casks

10 Casks

$\$ 3,887$

$\$ 3,301$

$\$ 2,790$

3,741

4,819

3,030

3,999

$\$ 2,794$

3,726

2,686

3,231

2,046

2,482

1,833

2,232

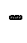

$4,383 \quad 3,565$

5,900

4,972

$3 ; 292$

4,663

The 10 cask case for the reference shipping cask was calculated inasmuch as it was assumed that at least 10 casks of the reference design would be procured for the DOE cask fleet.

\section{(2) Other Costs Associated with Fabrication}

Other costs associated with fabrication include acceptance testing, performance evaluation, support to DOE, management and administration, and quality assurance. Here again, since no detailed breakdown of these costs was publicly available for the NUPAC rail cask, independent estimates of the costs were made during the course of this study. The difference between the costs estimated in this study and those set forth in Section 4.1.2.1 was taken as a contingency that was applicable to the other costs associated with cask fabrication. A summary of the estimated additional costs. associated with cask fabrication for the reference NUPAC cask and the MESC casks is set forth in Table 4-7.

The professional fees and expenses shown in Table 4-7 were developed from estimates of the professional time required for the activities as estimated during the study, and using a $\$ 75 /$ hour professional fee rate. All other costs were estimated during the course of the study.

Using the foregoing methodology, it was determined that the costs so calculated for the two prototype NUPAC rail casks were about 17 percent less than the estimated costs under the contract 
TABLE 4-7

ESTIMATED ADOITIONAL COSTS ASSOCIATED WITH THE FABRICATION OF FROM-REACTOR SNF SHIPPING CASKS

$(\$ 000)$

Professional Fees \& Expenses

Travel Expenses

Rental Equipment

$\stackrel{8}{6}$

Miscellaneous Supplies

Contingency (17\%)

Total (1987 Dollars)

Escalated Total (1988 Dollars)

\begin{tabular}{|c|c|}
\hline $\begin{array}{l}\text { Two } \\
\text { NUPAC } \\
\text { Rai } \\
\text { Casks }\end{array}$ & $\begin{array}{c}\text { Single } \\
\text { NuPAC } \\
\text { Rail } \\
\text { Cask }\end{array}$ \\
\hline 950 & $\$ 620$ \\
\hline 123 & 78 \\
\hline 82 & 41 \\
\hline 23 & 15 \\
\hline 1,178 & 754 \\
\hline 201 & 128 \\
\hline
\end{tabular}

Single 24 PWR Assy

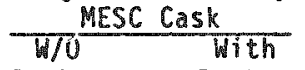

Basket Basket

$\$ 522$

\$ 652

81

48

19

\begin{tabular}{l}
670 \\
114 \\
\hline
\end{tabular}

81

48

$\frac{19}{800}$

136

single 7 PWR Assy $\frac{\text { MESC Cask }}{\text { W/0 With }}$ Basket Basket

$\$ 437$

$\$ 567$

69

$36 \quad 36$

-12 $\quad 12$

554

94

116

$\$ 1,379$

$\$ 1,429$

$\$ 914$

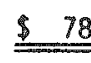

$\quad 812$

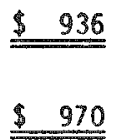

\begin{tabular}{l}
$\$ 648$ \\
$\$ \quad 671 \quad \$ 800$ \\
\hline$\quad 829$ \\
\hline
\end{tabular}

Single 2/7 PWR Assy MESC Cask with MESC With Both Basket Baskets

$\$ 580 \$ 755$

$81 \quad 81$

$48 \quad 48$

$-19$

$124 \quad 154$

$\$ 852 \quad \$ 1,057$

$\$ 883 \quad \$ 1,095$

Acceptance testing, performance evaluation, support to DOE, management and administration, and quality assurance

b Escalated from 1987 dollars to 1988 dollars using the Labor Index on Non-Agricultural Production Workers (1.036) 
between DOE and NUPAC. This was assumed to be the contingency associated with the costs involved, and the same contingency percentage was used for the MESC casks as well. The total costs were then increased by 3.6 percent to escalate them to 1988 dollars.

The estimated amounts of such other costs associated with fabrication of multiple numbers of casks was calculated using the linear relationship that was found to exist between the first and second reference NUPAC rail cask that was fabricated. This relationship can be expressed by the following algorithm:

$$
c_{n}=\frac{a(1+1.29 n)}{n}
$$

where $C_{n}=$ the other cost associated with the nth cask built in a single procurement

$\mathrm{n}=$ the number of casks procured in a given procurement

$a=a$ constant which is equal to 43.7 percent of the other fabrication costs associated with the procurement of a single cask

This produced the other fabrication costs associated with multiple cask procurements as shown in Table 4-8.

TABLE 4-8

ESTIMATED OTHER COSTS ASSOCIATED WITH FABRICATION OF SNF SHIPPING CASKS

AS A FUNCTION OF THE NUMBERS OF CASKS BUILT IN A SINGLE PROCUREMENT ${ }^{a}$

$$
(\$ 000,1988)
$$

Cost Per Cask For Indicated Number of Casks Built

\section{Cask Type}

Reference NUPAC Shipping Cask

24 PWR Assembiy MESC Cask

W/O Basket

With Basket

7 PWR Assembly MESC Cask

W/O Basket

With Basket

2/7 PWR Assembly MESC Cask

W/MESC Basket

W/Both Baskets
1,095
829

883

812
970

671

1,095
2 Casks

$\$ 715$

$\begin{array}{llll}1 \text { Cask } & 2 \text { Casks } & 3 \text { Casks } & 10 \text { Casks } \\ \$ 914 & \$ 715 & - & \$ 554\end{array}$

10 Casks
634

758

525

648

$\$ 575$

688

476

587

690

857

626

777

$\bar{a}$ Acceptance testing, performance evaluation, support to DOE, management and administration, and quality assurance 


\section{(3) Design and Development}

It was assumed that the \$3.9-million cost for design and development of the reference NUPAC rail cask would al so constitute the basic cost for the development of a family of casks of similar design though of difference size. For the purposes of this study, it was assumed that 30 percent of the design and development cost was associated with the cask basket (\$1.17-million) and 70 percent was associated with the cask body (\$2.73-million).

However, it was also assumed that there would be additional design and development costs associated with the MESC casks, and that these additional costs would amount to 20 percent of the cost of design and development of the cask body and of the cask basket for assemblies (where such was applicable). Moreover, it was assumed that the cost of design and development of the MESC basket would involve an additional cost of 30 percent of the cost of design and development of the reference cask basket. This resulted in added costs for cask design and development of MESC casks, as follows:

TABLE $4-9$

ESTIMATED ADDED COSTS FOR DESIGN AND DEVELOPMENT OF MESC SHIPPING CASKS

$$
(\$ 000,1988)
$$

Cask Type

7 \& 24 PWR Assembly MESC Casks

W/O Basket

With Basket

2/7 PWR Assembly MESC Casks

W/MESC Basket

W/Both Baskets

Added Costs for Single Cask

$\$ 547$

781

781

1,016

For multiple units of the MESC casks, the above design and development costs would be divided by the number of casks involved.

\section{(4) Model Fabrication and Associated Costs}

For the purposes of this study it was assumed that the development, fabrication and testing of the model for the reference NUPAC shipping cask would suffice as well for the licensing of a 7 PWR assembly MESC cask. However, it was assumed that the 24 PWR assembly MESC cask would require the development, fabrication, and testing of a completely new model -- but that such model would also suffice for the licensing of the $2 / 7$ PWR assembly MESC cask. 
The fabrication cost of the new model was developed by multiplying the costs of fabrication of the reference model cask by the ratio of the cost of fabrication of a single full-sized 24 PWR assembly MESC shipping cask to that for fabrication of a single full-sized reference cask (both with baskets). The other costs associated with the development of the new model were determined by multiplying the other such costs involved for the reference model cask by the ratio of such other costs for a single full-sized 24 PWR assembly MESCs cask to that for a single full-sized reference cask (both with baskets).

The estimated cost of the models for multiple numbers of casks represented thereby was calculated by spreading the cost of model development over the numbers of casks involved.

\section{(5) Auxiliary Equipment}

The estimated cost of auxiliary transport equipment was taken as $\$ 0.664-\mathrm{mill}$ ion (1988 dollars). This consisted of $\$ 0.553-\mathrm{mill}$ ion for a rail car, personnel barrier and tie downs, plus $\$ 0.111$ million for a lift beam, special tools and miscellaneous equipment. This estimate is the same as that reported in Reference 10, with escalation added. It was assumed that every cask would require a set of this auxiliary equipment and that the cost thereof would be the same for both the reference shipping cask and the MESC casks.

\section{NRC Certification Fees}

The NRC Certification Fees that are applicable as of January 1989 amount to about $\$ 0.165-m i l l i o n$. There is a proposed change in 10CFR170 and 171 that, if approved, would allow NRC to collect a certification fee that represented the full recovery of all of the costs it incurs in connection with a given certification. Notwithstanding the foregoing, a \$0.165-million certification fee was used for the design of both the reference shipping cask and the 24 PWR assembly MESC cask. No certification fee was assumed for the 7 PWR assembly MESC cask or the $2 / 7$ PWR assembly MESC cask since it was assumed that these would be certified along with the reference and 24 PWR assembly MESC casks.

The estimated cost of certification of a given cask type was spread over the numbers of casks built.

\section{(7) Allocation of Added Cost of Reference Casks}

For the purpose of this study, it was assumed that at least 10 reference shipping casks of a given design would be procured by DOE for its cask fleet. If MESC casks were substituted for one or more of the reference shipping casks, the total cost of the latter would be expected to rise inasmuch as there would be fewer numbers of casks over which to spread the cost of design and development, models, special fabrication equipment, fixed acceptance testing costs and certification fees. These added costs are as follows: 
TABLE $4-10$

ADDED COST OF REFERENCE SHIPPING CASK AS A RESULT OF

PROCUREMENT OF FEWER NUMBERS OF A GIVEN DESIGN

$(\$ 000,1988)$

Description

Development Costs

Models

Fabrication

Acceptance Testing

Certification

Total
Added Cost

(Per Cask)

$\$ 390$

209

116

52

17

$\$ 784$

The added costs attributable to the MESC casks were calculated by adjusting the above costs to account for the differences between the capacities of the MESC casks and the reference FWMS shipping cask, on a linear basis. This gave the following additional costs of the reference casks that resulted from the use of the various MESC casks.

TABLE 4-11

ADDED COSTS ATTRIBUTABLE TO MESC CASKS AS A RESULT

OF PROCUREMENT OF FEWER NUMBERS OF REFERENCE SHIPPING CASKS

$(\$ 000,1988)$

Description

24 PWR Assembly MESC Cask ${ }^{2}$

7 PWR Assembly MESC Cask ${ }^{b}$

$2 / 7$ PWR Assembly MESC Cask ${ }^{c}$
Added Cost

(Per Cask)

$\$ 896$

$\$ 261$

$\$ 971$

a 24/21 times total from Table 4-10
b $7 / 21$ times total from Table 4-10
c $26 / 21$ times total from Table 4-10 
4.1.2.3 Estimate of Freight and Other Costs Associated With Cask Use

Estimates of costs were developed for operating expenses associated with the use of the reference shipping cask and MESC shipping casks, as well as freight charges, security escort costs, and decomissioning costs. These costs were developed for two different shipping distances - 500 miles and 2800 miles, which are those assumed to be applicable for shipments from reactor sites using MESCs for storage and the MRS and repository facilities, respectively. In the event other reactor sites commit to the use of MESCs, additional distance cases would have to be estimated.

The number of cask shipments that could be achieved in a single year for each of the above distances was calculated to be 18 for the 500-mile shipments (17 where MESCs were opened and unloaded while still in the cask) and 8 for the 2800-mile shipments (for all cases). This was based on rail speeds of 88 miles/day for a 500-mile (one-way) shipment and 182 miles/day for a 2800-mile (one-way) shipment. The turnaround time of the cask was taken at 4.5 days/shipment (per the 1988 TSLCC assumptions); an additional 8 hours/shipment was allowed for opening of the MESC while they were still in the cask and 10 hours/shipment less time was allowed where the loaded MESC was removed from the cask and unloaded in the hot cell.

The cost of freight and other transport-related costs were calculated as described in the following:

\section{(1) Operating Costs}

Operating costs include cask maintenance and the cost of inspectors dispatched to reactor locations to observe the loading of shipping casks there.

A cost for cask maintenance of \$125-thousand/year was used in this study; this was the figure obtained from the assumptions used in the 1988 Total-System Life Cycle Cost (TSLCC). In addition, this document included an assumption that two inspectors would be provided for one shift a day while the shipment is at the reactor. The cost of these inspectors, including their associated travel costs was estimated to be $\$ 4,700 /$ cask trip (1988 dollars). This results in operating costs of \$210-thousand/year for 500-mile shipments (\$205-thousand/year where the MESC was opened and unloaded while still in the cask), and \$163-thousand/year for 2800mile shipments. 
(2) Freight Charges

The freight rates were determined using the algorithms developed in Reference 10 for shipments of both loaded and empty casks, as follows:

$$
\begin{aligned}
& R_{l}=0.16780^{0.5815} \\
& R_{e}=0.16000^{0.5790}
\end{aligned}
$$

where $\quad R_{1}=$ the freight rate for the loaded cask (CWT)

$R_{e}=$ the freight rate for the empty cask (CWT)

$D=$ the one-way shipment distance

The freight rates so determined amounted to $\$ 6.23 /$ CWT loaded and $\$ 5.85 /$ CWT empty for 500-mile shipments, and $\$ 16.96 /$ CWT loaded and $\$ 15.85 /$ CWT empty for 2800-mile shipments. These were then escalated to 1988 dollars from 1986 dollars (the basis for the algorithms in Reference 10) and multiplied by the weight of the shipping casks on the transport vehicle as described in Table 4-2. A minimum of $250,0001 \mathrm{~b}$ for loaded casks and $225,000 \mathrm{lb}$ for empty casks was assumed to be applicable for these freight rates*. This produced the total freight costs for a single round-trip shipment of both MESC shipping casks and the reference cask shown in Table 4-12.

TABLE 4-12

FREIGHT COSTS FOR A SINGLE ROUND TRIP SHIPMENT OF MESC SHIPPING CASKS AND THE REFERENCE SHIPPING CASK ${ }^{a}$

Cask Type

Reference Rail Cask

24 PWR Assembly MESC Cask

24 PWR Assembiy MESC Cask

7 PWR Assembly MESC Cask

7 PWR Assembiy MESC Cask

2/7 PWR Assembly MESC Cask

2/7 PWR Assembiy MESC Cask

$\overline{a_{A 11}}$ casks are rail casks.

Cost of a Single Round-Trip

Form of Fuel

Shipped

Assemblies

MESCS

Assemblies

MESCS

Assemblies

MESCS

Assemblies
Shipment (1988 Dollars) 500 Miles 2800 Miles

$\$ 29,888$ $\$ 81,186$

32,479

88,241

30,726

83,466

29,888

81,186

29,888

81,186

32,878

89,314

33,745

91,668

*No allowance was made for any premium rates that might apply to extra-heavy shipments (i.e.s those over 263,000 Tb). 


\section{(3) Security Escort Charges}

The 1988 TSLCC assumptions included provisions for two armed escorts to accompany rail shipments of spent fuel. The cost for these escorts was developed using the following assumptions:

(a) Two men (a guard sergeant and a security officer) would be located in the caboose during the entire loaded portion of the shipment. The sergeant would carry a rate of $\$ 13.01 / \mathrm{hr}$ and the officer a rate of $\$ 11.83 / \mathrm{hr}$. Each would receive 16 hours of pay for each 24 hours involved in the shipment. The guards' pay would carry a 35 percent burden; a 13 percent general administrative cost would be applied to the salary rate plus burden; and a 5 percent profit would be applied to the sum of the foregoing. This produces a total of $\$ 637 /$ day for the escorts. This cost was applied to the total elapsed time of the shipment plus a 16 hour layover, air travel at $500 \mathrm{mph}$, and 4 hours for ground travel time.

(b) Each of the guards would each receive a $\$ 26 /$ day subsistence allowance.

(c) In addition to (b), above, the guards would receive $\$ 73 /$ day for hotel and taxi expenses on the return trip.

(d) A rail fare of $\$ .089 / \mathrm{mil}$ e per guard was assumed to be applicable to the shipment. Air fare was estimated at $\$ 0.30 / \mathrm{mile}$ per guard for the return trip.

(e) A security equipment charge of $\$ 12 /$ day (total) was assumed to be applicable.

These costs were developed by escalating similar costs used to develop estimated transportation costs in Reference 10 using applicable indexes. Using the above costs, the security costs associated with a single 500-mile shipment would amount to $\$ 5,131$, and for a 2800-mile shipment would amount to $\$ 13,855$.

\section{(4) Decommissioning Costs}

The cost of disposal of shipping casks at the end of their useful life was estimated using the following assumptions:

(a) The freight rate for the shipment of the cask to a lowlevel waste burial site was estimated as being that of a 1500-mile shipment of an empty cask calculated as described in (2), above, (\$11.43/CWT).

(b) The cost of disposal was determined by multiplying the volume of the shipping cask, excluding impact limiters by the applicable 1988 Chem-Nuclear low level waste burial charges plus a weight surcharge and a local tax of 2.4 
percent on the total. The base disposal charges, taxes, fees and funds amounted to $\$ 44.73 / \mathrm{cu}$. ft. The weight surcharges amounted to $\$ 2,520$ for the first $50,0007 \mathrm{~b}$ plus $\$ 605 / 10,000$ 1b thereafter (11). The weight of the empty cask without impact limiters was used as the basis for calculating the weight surcharge.

(c) For the case where both a MESC basket and an assembly basket was used in connection with a MESC shipping cask, the cost of disposal of the MESC basket was estimated on the basis that the basket would be compacted to 33 percent of theoretical density, using the $\$ 44.78 / \mathrm{cu}$. $\mathrm{ft}$. disposal charge. It was assumed that it could be disposed of under the weight surcharge paid for the cask, and. that it could be shipped with the cask, with no additional charges being applicable thereto. Volume reduction of the MESC cask was estimated to require 160 person hours of effort at $\$ 65 /$ hour fully burdened and with overhead and G\&A, and materials costs associated therewith were estimated at $\$ 500$.

(d) A 15 percent contingency was added to the above costs.

A summary of the estimated total costs for disposal of the reference shipping casks and each type of MESC cask considered in this study is set forth in Table 4-13.

The above charges were developed on the assumption that disposal may take place at any one of several low level waste burial sites. The Chem-Nuclear charges have been used in developing the estimated costs described in Table 4-13 inasmuch as it was believed that these would be representative of costs that might be incurred during disposal at any low level waste burial site, including any special site developed by DOE for this purpose.

Moreover, it is possible that the foregoing costs might be reduced considerably if the casks could be sufficiently decontaminated for the contained metal to be sold for salvage. However, this would require careful testing and certification prior to release to unrestricted use. 
TABLE 4-13

SUMMARY OF ESTIMATED SHIPPING CASK DISPOSAL COSTS

(1988 Dollars)

\section{Description}

$\stackrel{i}{\infty}$

Volume Reduction

$\stackrel{\leftrightarrow}{\infty}$

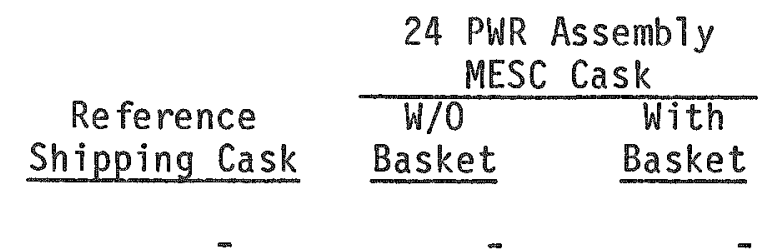

$\$ 25,830$

35,265

61,095

Contingency (15\%)

Total $\underline{9,164 \quad 10,907 \quad 11,065}$

$\$ 70,259 \quad \$ 83,622$

$\$ 25,830 \quad \$ 25,830$

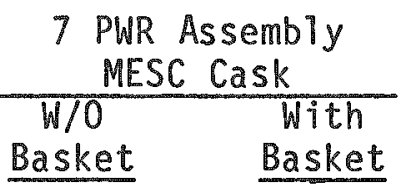

\section{2/7 PWR Assembly}

MESC Cask

W/MESC W/Both

Basket Baskets

$-\$ 11,000$

$\$ 25,830 \quad \$ 25,830$

$\$ 25,830$

25,830

$\underline{22,199 \quad 22,633}$

$\underline{54,548}$

58,188

$48,029 \quad 48,463$

80,378

95,018

7,204

7,269

12,05

14,253

$\$ 55,23$

$\$ 55,732$

$\$ 92,435 \quad \$ 109,271$ 


\subsubsection{Life Cycle Transport Costs and Unit Costs}

The total life cycle costs associated with the use of a single reference shipping cask and MESC shipping casks for shipments from reactors to DOE facilities were developed assuming the casks would be utilized to their full capacity over their assumed 20-year lifetime -- to ship either individual PWR assemblies or MESCs containing PWR assemblies, exclusively. These cost calculations and the assumptions associated therewith have been included in Appendix $A$ and are summarized in Table 4-14.

TABLE 4-14

COMPARISON OF UNIT COSTS FOR TRANSPORT OF SNF IN

REFERENCE SHIPPING CASK AND MESC SHIPPING CASKS $^{2}$

$(\$ / \mathrm{kgU}, 1988)$

Cask Type

Reference Shipping Cask

Single 24 PWR Assembly MESC Cask

in DOE Fleet

MESCS

Assemblies
Unit costs for Indicated

One-Way Shipping Distances
500 miles

$\$ 6.68$
2800 miles

$\$ 16.17$

Two 24 PWR Assembly MESC Casks

in DOE Fleet

MESCS

Assemblies
7.09

7.18

16.50

17.01

18.57

19.30

$(0.41)$

(0.50)

Single 7 PWR Assembly MESC Cask

in DOE Fleet

MESCS

Assemblies
$20.68 \quad(14.00)$

$21.44 \quad(14.76)$
48.47

51.01
$(32.30)$

$(34.84)$

Single 2/7 PWR Assembly MESC

Cask in DOE Fleet

MESCS

Assemblies
12.65

7.34
$(5.97)$
$(0.06)$
29.41

17.55

a Numbers in parentheses represent an increase in unit cost over that for shipping individual fuel assemblies in the reference shipping cask. 
It should be pointed out that the costs shown in the foregoing table represent the lowest unit costs possible under the estimated cost of casks, freight, etc., inasmuch as the casks were assumed to be fully utilized during their lifetime. From the information set forth in the table, it can be seen that the unit costs for shipment of either individual fuel assemblies or MESCs in MESC shipping casks were invariability higher than the unit cost for shipment of individual fuel assemblies in the reference shipping cask.

It was recognized that there is no current reason to expect that shipment of MESCS would commence as early as 2003, and that current plans of utilities only provided for up to 1900-2000 MTU (4224 PWR assemblies) to be stored in 24 PWR assembly MESCs and up to 26 MTU (56 PWR assemblies) to be stored in 7 PWR assembly MESCs -- although there is a distinct possibility that utilities will commit to store additional quantities of SNF in such a fashion (particulariy in the higher capacity MESCs). Considering the existing known plans of utilities in this regard, it was determined that a single 24 PWR assembly MESC shipping cask and a single 7.PWR MESC shipping cask would have sufficient capacity for transport of the MESCs, except in the case of long distance shipments where two 24 PWR assembly MESC casks might be needed. Therefore, additional total life cycle costs associated with the use of the casks were developed for a range of quantities so that the sensitivity of unit costs to the quantities of PWR assembries shipped in MESCs could be determined. This was done in two different ways; (i) assuming the cask would be used to ship individual PWR assemblies to the extent there were insufficient MESCs available to fully utilize the cask capacity over its assumed 20-year lifetime, and ( $i i)$ assuming the cask would be used to ship only MESCs and that the cask would be utilized only to the extent that MESCs were available for shipment. These cost calculations and the assumptions associated therewith have been included in Appendix $B$ for the 24 PWR assembly MESC cask. Appendix $C$ for the 7 PWR assembly MESC cask. Appendix $D$ for the $2 / 7$ PWR assembiy MESC cask, and a summary of the increases in unit costs over those involved with transport of individual PWR assemblies in the reference shipping cask is set forth in Table 4-15. 
TABLE 4-15

INCREASE IN UNIT COSTS FOR THE TRANSPORT OF PWR ASSEMBLIES IN MESCS OVER TRANSPORT IN UNCANISTERED CONDITION IN A REFERENCE SHIPPING CASK (1988 Dollars)

Cask Type

24 PWR Assembly MESC Shipping Cask
Total

Distance

Shipped

(miles)

500

$\begin{array}{rr}500 & 564 \\ & 940 \\ & 1,504 \\ 2,800 & 1,880 \\ & 534 \\ & 890 \\ & 1,424 \\ & 1,780\end{array}$

Quantity Shipped in MESCS (MTU) ${ }^{a}$
Increase in Unit cost $(\$ / \mathrm{kgU})$ Resulting From

Mixed Use of Cask $\$ 14.34$ 8.49

5.21

4.09

7.63

4.65

2.97

2.40
Use

Dedicated to MESCS

$\$ 16.69$

10.18

6.54

5.32

24.04

14.46

9.08

7.30

7 PWR Assembly MESC

Shipping Cask

$\begin{array}{rr}500 & 58 \\ & 116 \\ 2,800 & 232 \\ & 52 \\ & 104 \\ & 208\end{array}$

58

116

232

52

208

500

55

2/7 PWR Assembly

MESC Shipping Cask

$\begin{array}{rr}500 & 55 \\ & 110 \\ 2,800 & 220 \\ & 52 \\ & 104 \\ & 208\end{array}$

110

220

52

208

409.60

199.39

95.89

445.95

222.98

104.93

75.78

41.20

23.24

81.57

46.30

29.49
93.26

51.72

30.96

118.90

72.58

49.47
133.79

68.33

36.09

145.44

77.23

43.13

\footnotetext{
assumes each PWR fuel assembly contains $461 \mathrm{kgU}$ prior to irradiation. bused to ship both individual assemblies as well as MESCs as available.
} 
The increases in unit cost were calculated by taking the increase in the cost of shipping spent fuel in MESC shipping casks and attributing it solely to the cost of MESC shipments. In cases where a cask was used solely for shipments of MESCs when they were available, an addition to the unit cost was made amounting to $\$ 1.85 / \mathrm{kgU}$ for the 500 -mile shipment cases and $\$ 4.18 / \mathrm{kgU}$ for the 2800-mile shipment cases to effect a prorata charge for a lower utilization of the reference cask as a result of having the MESC cask in the DOE fleet.

From the information contained in the foregoing table, the following can be concluded:

(1) The shipment of PWR assemblies in MESCs is generally more expensive than the shipment of individual PWR assemblies in the reference shipping cask.

(2) The use of the 24 PWR assembly and 2/7 PWR assembiy MESC casks are generally more expensive when used solely for shipment of MESCs (dedicated use) than when they are fully utilized by shipping both individual PWR assemblies and MESCs to the extent the latter are available (mixed use), within the quantity range studied.

(3) The use of a 7 PWR assembly MESC cask is less expensive when used solely for shipment of MESCs (dedicated use) than when they are fully utilized by shipping both individual PWR assemblies and MESCs to the extent the latter are available (mixed use), within the quantity range studied. This is due to the high cost of shipping individual PWR assemblies in the 7 PWR assembly MESC cask over that of shipment in the reference cask, and the fact that this much higher cost has to be allocated to the relatively small amount of SNF contained in the 7 PWR assembly MESCs.

Considering the fact that the weight of the 24 PWR assembly MESC cask and the 2/7 PWR assembly MESC cask loaded with individual PWR assembi ies (127 tons and 121 tons, respectively) may be too high for all reactors having rail access to use, the most conservative approach would be to assume that the MESC casks would only be used for the shipment of MESCs. Also, under these circumstances it would appear that the use of a 7 PWR assembly MESC shipping cask would be preferable to the use of a $2 / 7$ PWR assembly MESC shipping cask.

The high cost of shipping the 7 PWR assembiy MESC casks might be avoided if the utility had a shipping cask (e.g., the IF-300 cask) that could be used for the shipment and would provide it at no cost to DOE. In such an 
instance, only the freight and escort charges shown on Tables $C-7$ through $C-12$ of Appendix $C$ would be incurred by the FWMS. These amount to $\$ 10.26 / \mathrm{kgU}$ for a 500-mile shipment and $\$ 29.23 / \mathrm{kgU}$ for a 2800-mile shipment, or an increase of $\$ 3.63 / \mathrm{kgU}$ and $\$ 13.17 / \mathrm{kgU}$, respectively, over the cost of use of the reference cask for shipping individual fuel assemblies.

The increases in unit costs set forth in Table $4-15$ were based on the assumption that loaded casks (both the reference cask and MESC casks) would be shipped by regular train. In the event the loaded reference casks were shipped by special train, with 3 casks being involved in a single shipment, the cost per cask shipment could be reduced by as much as 28 percent for a 500-mile shipment and by as much as 12 percent for a 2,800-mile shipment. This reduction amounts to about $\$ 2.00 / \mathrm{kgU}$ and $\$ 2.50 / \mathrm{kgU}$, respectively, for shipments of 500 and 2,800 miles. The reduction in costs associated by the shipment of MESC shipping casks by special train could be expected to be slightly higher because of the shorter overall time required for the shipment by special train and the higher cost of MESC shipping casks. Thus, the impact on the increases in unit costs shown in Table 4-15 that is occasioned by the use of special trains instead of regular trains can be expected to be small.

\subsection{MESC PROCESSING IN FWMS FACILITIES}

This section reports the results of the study of the impacts and costs associated with the acceptance of MESCs at MRS or repository facilities.

\subsubsection{Processing Alternatives for MESCS}

There are three basic alternatives for handing MESCs in the FWMS facilities regardless of whether or not a MRS facility is included therein. These alternatives are shown in the block diagram set forth in Figure $4-1$ and are summarized in the following:

Alternative 1 - - The weld on the MESC lid and shield plug could be cut open while the MESC still is in either the shipping cask or a transfer cask and the assemblies unloaded into the hot cell facilities, in the same way they would otherwise be unloaded (and subsequently handled and processed) from a reference shipping cask (one that was designed for shipping individual SNF assembiies). Subsequently, the MESC could be decontaminated using the equipment normally used for decontamination of cask internals, unloaded from the shipping or transfer cask, and packaged for disposal. 


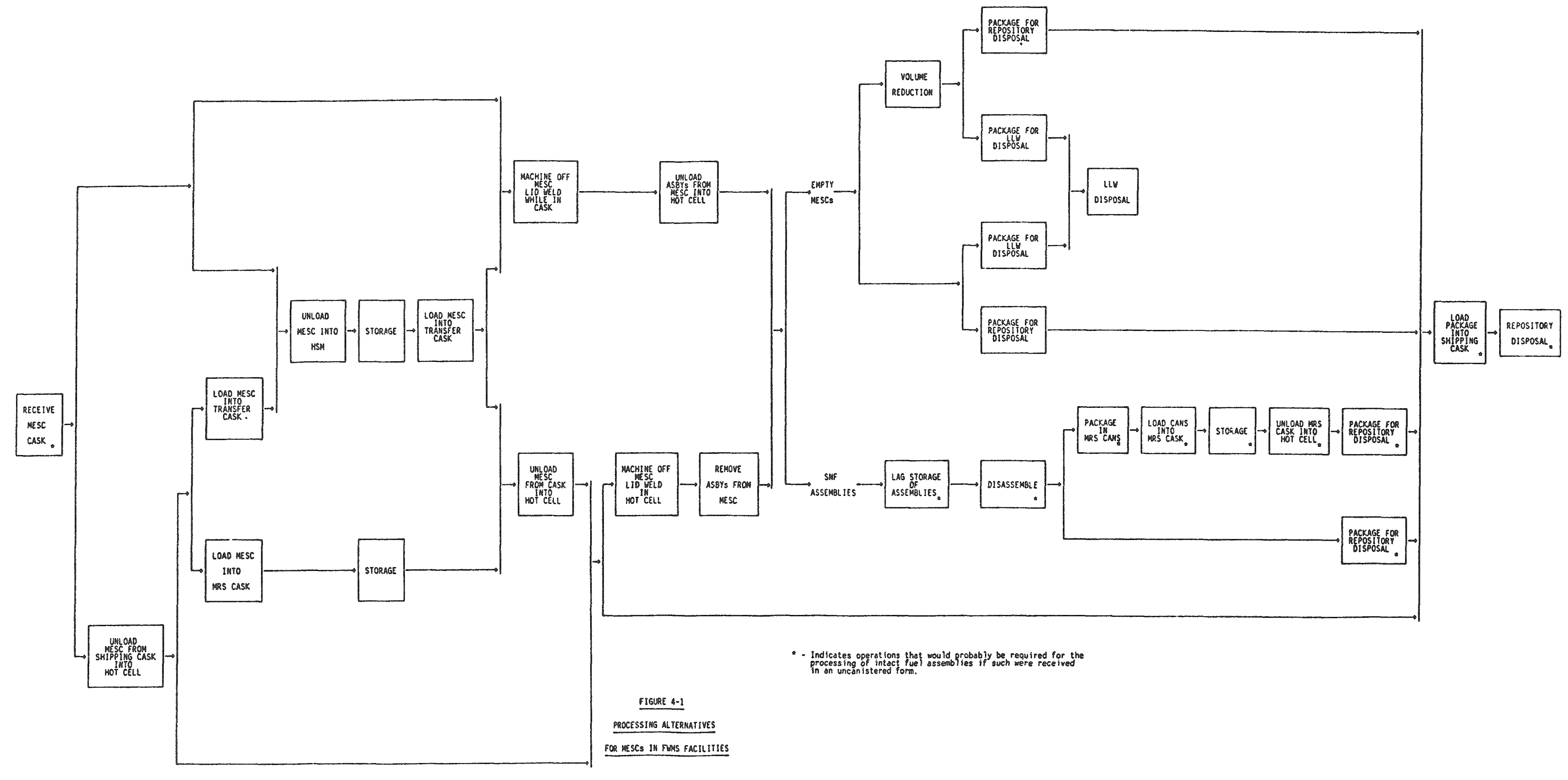


Alternative \#2 -- The MESCs could be unloaded into the hot cell facilities and the weld on the MESC lid and shield plug could be cut open inside the hot cell, the contained assemblies unloaded, and the MESC decontaminated and packaged for disposal. Some lag storage space for the MESCs would be required in the hot call whether they were subsequently stored in separate interim storage facilities (MRS) or processed directly. Once the assemblies were removed from the MESC in the hot cell they would be subsequentiy handled and processed in the same way they would have otherwise been had they not been received in MESCs.

Alternative \#3 -- There has been a suggestion that MESCs might be used as a repository package and might not have to be unloaded in the FWMS facilities (2). However, the design of the repository package represents a vital part of the waste isolation system and is not expected to be finalized for a number of years in the future. Therefore, it does not appear to be possible presently to specify the characteristics of a MESC that would meet the requirements of a repository package, nor reasonable to force the designers of the repository package to design the package around the characteristics of a MESC. Moreover, MESCs will probably be needed to meet atreactor storage requirements (to the extent they are so used) prior to finalization of the design of the repository package, and the SNF assemblies contained therein will represent only a fraction of the total number of assemblies expected to be received by the FWMS. Therefore, the possible use of a MESC as a repository package was not considered in this study.

If there is a MRS facility in the FWMS, the MESCs could be stored there in in either vertically-loaded concrete casks or in horizontal concrete modules (HSM). MESCs could be directly loaded into HSMs from the shipping cask by pulling them in to the module, but would have to be unloaded from the shipping cask and subsequently loaded into the vertically-loaded concrete casks. MESCs could also be loaded into a transfer cask from the hot cell facilities and the transfer cask used to load the HSMs.

Al1 of the processing alternatives described in Figure 4-1, and outlined above, were considered in the course of this study, except the alternative where the MESC was used as a repository package, to identify:

(1) The most economical (and operationally efficient) combination of handling alternatives available for the SNF contained in MESC.

(2) The added cost or savings to the FWMS facilities resulting from the receipt of SNF in MESCS compared with the receipt of individual PWR assemblies in a reference shipping cask. 


\subsubsection{Reference Facility Design}

The design of the Integral Monitored Retrievable Storage (MRS) Facility, developed by The Ralph M. Parsons Co. (12), was used as the reference processing facility for evaluating acceptance of MESCs into FWMS facilities. This advanced conceptual design (ACD) has a capacity for receiving, handling and processing of 3,600 MTU/year of spent fuel in assembly form and has a capability for storing consolidated SNF in concrete storage casks. This particular facility design was selected because it represents a major design effort and the documentation available includes detailed drawings, equipment specifications and cost estimating data.

The design of processing facilities associated with the Nevada Nuclear Waste Storage Investigation Project (13), located at a proposed tuff repository site, was also evaluated with respect to MESC acceptance. Although the design of the Nevada spent fuel processing facilities is only preliminary, it was determined that any changes in the Parsons ACD would be representative of those changes and additions required at the Nevada facility as well.

The following provides a brief description of the facilities involved in the Parsons ACD:

\section{(1) Receiving and Handling Facility}

For illustrative purposes a simplified plan of ACD facility hot cells is shown in Figure 4-2. The four process hot cells are functionally identical except that one pair of hot cells would be dedicated to PWR fuel disassembly and rod consolidation and the other pair of hot cells would process BWR fuel. The ACD concept also uses 55-gallon drums as containers for shredded non-fuel bearing components from the fuel assemblies. The two large "canyon cells" are intended to be kept clean, or at a very low contamination level, as no bare fuel or fuel components are handled in these areas.

The ACD facility consolidates the spent fuel rods into 12-3/4 inch diameter canisters (schedule 20 stainless steel pipe). Each canister holds the consolidated rods from 3 PWR or 7 BWR fuel assemblies. Consolidation takes place in the four process hot cells. The canisters are loaded horizontally through a port in the wall separating the process and canyon hot cells. The two canyon cells contain the canister sealing and testing equipment. The canyon cells also contain the equipment'for placing the spent fuel canisters in repository overpacks and sealing the overpacks. The two canyon cells also contain forced air-cooled storage vaults with a combined capacity of approximately 1000 MTU of fuel in canisters. The design drawings and text do not indicate whether or not the 


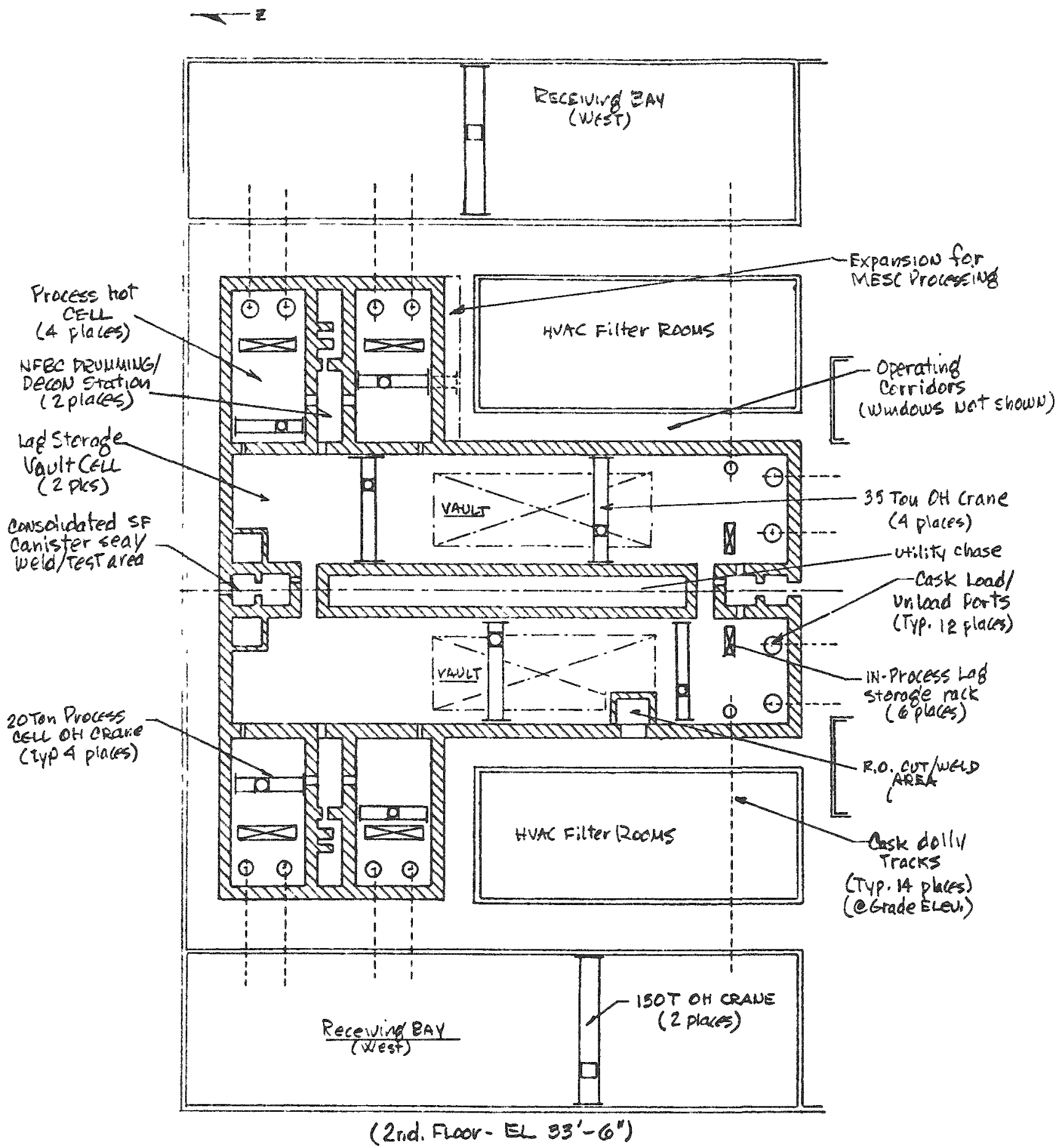

FIGURE 4-2

ACD FACILITY HOT CELL AREA 
vaults are arranged to hold loaded overpacks and NFBC drums, although it would be advantageous to do so. The process cells and canyon cells have small lag storage racks near the cask loading/unloading ports. The process cell lag storage racks can each hold about 80 MTU in the form of intact fuel assemblies which are held in removable, interchangeable support baskets while the canyon cell lag storage racks are designed to hold either canisters or repository overpacks.

\section{(2) MRS Area}

The ACD includes the design and layout of a 133 acre storage area for MRS with space for 1760 casks of consolidated and unconsolidated fuel (in canisters), non-fuel components, various types of radioactive waste, and a number of dual-purpose metal casks. The casks sit on long, 18 inch thick concrete pads.

\section{(3) MRS Casks}

The ACD includes the designs of concrete storage casks for holding canisters of spent fuel and other materials to be kept in the MRS area. Figure 4-3 illustrates the Parsons spent fuel storage cask which was designed to contain 12 canisters of consolidated fuel rods. The casks are moved to and from the storage area by a crawler type transporter and 1 ifted and placed by a 600-ton mobile crane.

It was determined that the ACD facility's concrete MRS casks could be easily adapted for storing MESCs with no impact on the cask handling or transport system or the total area required for storage. However, if MESCs were stored in the MRS area, it was evident that the total number of casks would be affected and it might be necessary to add additional support pads in the storage area.

Details of the modifications and additions to the ACD facility materials handling systems, hot cells, storage casks and MRS area required for the facility to be able to accept SNF in MESCs are discussed in detail, along with associated costs, in Section 4.2 .3 .

\subsubsection{Estimates of Cost Impacts at FWMS Facilities}

In order to estimate the costs of changes in the ACD facilities and equipment required to accept MESCs, the Parsons detailed cost estimates (in 1985 dollars) were used to determine appropriate unit costs for materials, construction labor, work-hours per task, overhead and burdens, and add-ons for engineering and construction management. The cost estimates thus 

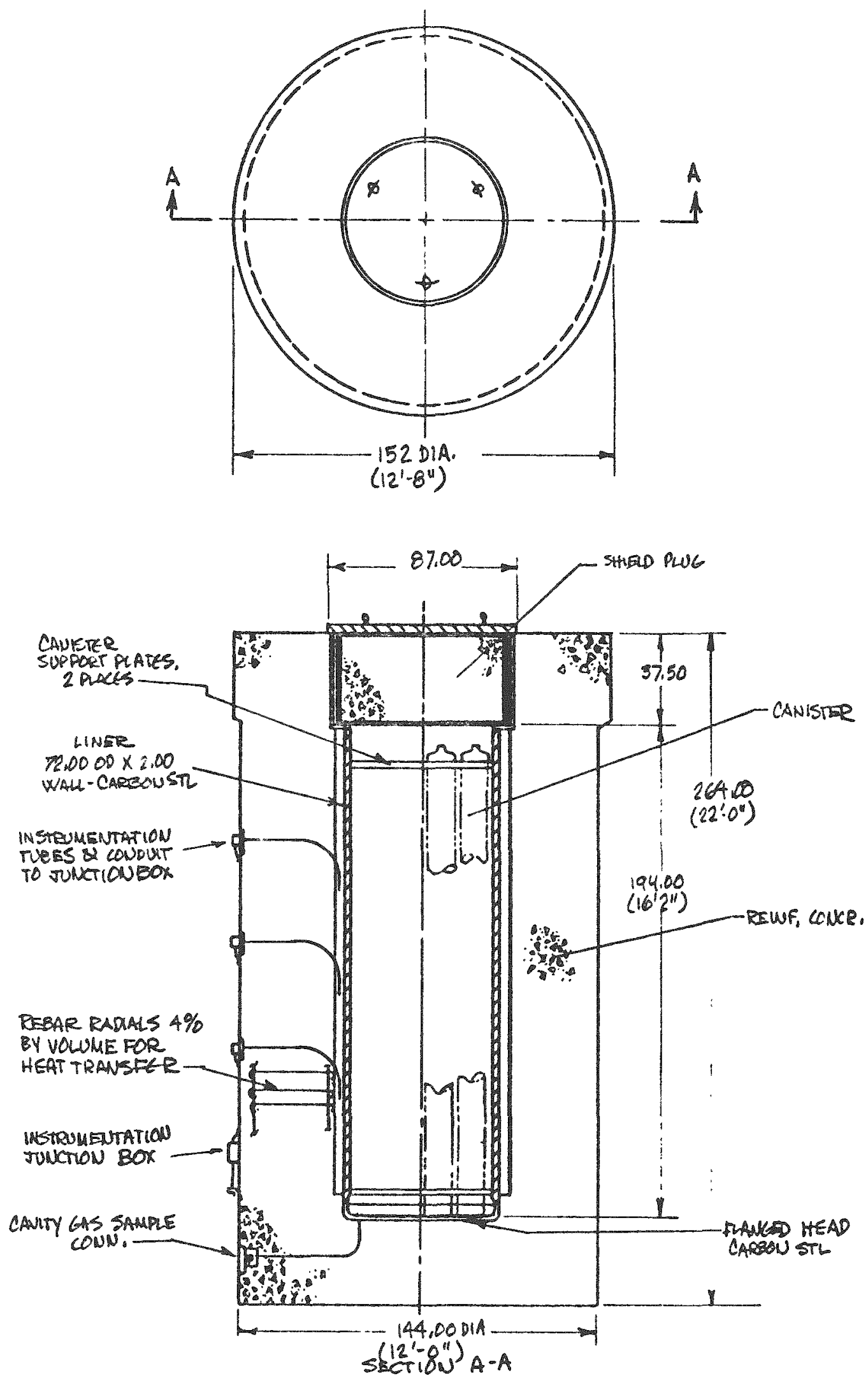

FI GURE $4-3$

ACD FACILITY SPENT FUEL STORAGE CASK 
developed for required changes in facility and equipment design occasioned by the acceptance of SNF in MESCs were determined on the same basis as was used by Parsons in its original cost estimates. These estimates were escalated with appropriate indices to 1988 dollars. In cases where the ACD facility cost estimating information was inadequate or missing, current labor, equipment and materials costs were obtained from industry vendors, services and cost estimating sources.

Estimates of additions (or savings) to the capital and operating costs of the reference ACD facility were developed for each of the MESC processing alternatives described in Section $4.2 . ?$ as being considered in this study. In the following Sections 4.2.3.1 through 4.2.3.9, the additional costs involved for each additional operation involved in the handling of MESCs in FWMS facilities are developed. Section 4.2.3.10 develops the incremental life cycle costs and associated unit costs for each of the alternatives considered for handling MESCS in FWMS facilities, and identifies those alternatives that are the most cost effective.

4.2.3.1. Cost of Equipment for Cutting Open MESCs Outside of Hot Cell Facilities

If MESCS are to be cut open outside of hot cell facilities the shipping casks (or transfer cask) would be received in the normal fashion, and after removal of the cask closure in the Cask Receiving Bay, a cutting machine would be fitted on the top of the cask and the outer cover seal weld removed. After removal of the outer cover, the shield plug seal weld would be removed. Removal of the cutting machine would then permit the cask to be positioned under the unloading port of the Process Cell and the fuel assemblies would be removed in the normal manner for processing. The cask, with the empty MESC would be removed to the decontamination station where the MESC internals and cask outside would be decontaminated. Following replacement of the shield plug and tack weiding, the MESC would be removed and the outside decontaminated preparatory to disposal.

The cost of the additional facilities was estimated at \$499thousand, as described in Table 4-16. 
TABLE $4-16$

ESTIMATED COST OF EQUIPMENT FOR OPENING AND HANDLING OF MESCS

$$
(\$ 000,1988)
$$

\begin{tabular}{lr} 
Description & Amount \\
\hline Weld Cutting Machine & $\$ 150$ \\
Vacuum Follower & 60 \\
Stand \& Frame & 50 \\
Remote Operation Controls \& Console & 35 \\
\hline & 295 \\
Construction Management (10\%) & 30 \\
System Design \& Engineering (25\%) & 74 \\
Contingency (25\%) & 399 \\
$\quad$ Total & $\$ 400$ \\
\hline
\end{tabular}

The foregoing costs are fixed costs and would have to be distributed over the total amount of SNF received in MESCS.

\subsubsection{Operating Costs for Cutting Open MESCs Outside of Hot Cell Facilities}

In addition to the required equipment described in Section 4.2.3.1, some additional operating costs would be involved in cutting open the MESCs outside the hot cell, as follows:

\section{(1) Labor and Materials}

The labor effort involved in setting up the cutting operation, performing the cutting work, installation of the lid lifting fixture, decontamination of the MESC after the assemblies have been removed, replacement of the shield plug and tack welding thereof, and removal of the MESC from the cask into the disposal container -was estimated to amount to 52 person-hours for a 24 PWR assembly MESC and 40 person-hours for a 7 PWR assembly MESC. A labor hour cost of $\$ 65.34$ was used which included wages, labor burden, supervision, support, overhead, general and administrative expenses, and operating supplies. This would produce an incremental unit cost of $\$ 0.31 / \mathrm{kgU}$ for 24 PWR assembly MESCs and $\$ 0.81 / \mathrm{kgU}$ for 7 PWR assembly MESCs based on an assumed initial uranium content of $461 \mathrm{~kg} / \mathrm{assembly}$. 
(2) Utilities: Maintenance Parts and Supplies

An allowance was made for the cost of utilities and maintenance parts and supplies amounting to $\$ 200$ for the opening and handling of a 24 PWR assembly MESC and $\$ 150$ for a 7 PWR assembly MESC, such would amount to $\$ 0.02 / \mathrm{kgU}$ and $\$ 0.05 / \mathrm{kgU}$, respectively.

Thus, the total incremental unit costs for cutting open the MESCs outside the hot cell facilities and the handling thereof amounts to $\$ 0.33 / \mathrm{kgU}$ for a 24 PWR assembly MESC and $\$ 0.86 / \mathrm{kgU}$ for a 7 PWR assembly MESC.

\subsubsection{Cost of MESC Disposal}

The cost of MESC disposal will be the same for both alternatives examined (either cutting open the MESC in the cask outside the hot cell facilities, or in the hot cell after removal from the cask). The cost of MESC disposal includes the labor associated with the packaging of the MESC and its preparation for shipment, package costs, shipping costs, and burial ground fees. Volume reduction, by cutting up or melting down the MESC, was not considered inasmuch as it would require additional processing areas, equipment and operating labor -- and was expected to be more expensive than disposal of the intact MESC. A summary of these estimated costs (a11 incremental) is set forth in Table 4-17.

TABLE 4-17

ESTIMATED MESC DISPOSAL COSTS

(1988 Dollars)

\begin{tabular}{|c|c|c|}
\hline & $\begin{array}{l}\text { PWR Assembly } \\
\text { MESC }\end{array}$ & $\begin{array}{c}7 \text { PWR Assembiy } \\
\text { MESC }\end{array}$ \\
\hline $\begin{array}{l}\text { Labor (disposal preparation) } \\
\text { Disposal Container } \\
\text { Shipping Cost } \\
\text { Burial Ground Fees }\end{array}$ & $\begin{array}{r}1,094 \\
4,050 \\
1,650 \\
22,111 \\
\end{array}$ & $\begin{array}{r}\$ 1,094 \\
2,151 \\
825^{b} \\
7,182 \\
\end{array}$ \\
\hline Total Disposal Cost & $\$ 28,905$ & $\$ 11,252$ \\
\hline Total Unit Cost & $\$ 2.61 / \mathrm{kgU}$ & $\$ 3.49 / \mathrm{kgU}$ \\
\hline \multicolumn{3}{|c|}{$\begin{array}{l}\text { a Based on an assumed } \$ 1.65 / \text { mile for a } 1000 \text {-mile shipment } \\
\text { b Assumed two } 7 \text { PWR assemblies MESCs can be shipped in a single shipment } \\
\text { c Based on Chem Nuclear rates for Barnwell disposal site effective January } 15 \text {, } \\
1988\end{array}$} \\
\hline
\end{tabular}




\subsubsection{Cost of Additions to ACD Facility Receiving and Hot Cell Facilities}

If MESCs are to be opened ultimately in the hot cell facilities of the FWMS, some modification and/or additions will be required to the shipping cask receiving facilities, the process hot cells, and lag storage facilities. These modifications and/or additions are described in the following:

\section{(1) Receiving, Inspection and Shipping Area}

Both of the transport cask receiving bays in the ACD facility have 150-ton bridge cranes for shipping cask handling and they are entirely adequate for handling the MESC shipping casks. MESC transport cask handling and preparation for top closure removal or replacement is not seen as being different from any other spent fuel shipping cask that would be used in the FWMS. However, each type, style or size of cask used in the FWMS requires a unique set of handling fixtures; i.e., cask lifting yoke adaptor, cask transfer cart adaptor and unloading cell contamination control barrier. These items would normally be considered a part of the facility tool and equipment complement. Thus, it is to be expected that each MESC rail shipping cask design would have different dimensions than other casks in the FWMS fleet and that each would require a special set of cask handling tools.

The ACD facility cask unloading/loading cells appear to be adequately sized to permit the receipt and unloading of SNF assemblies from MESC shipping casks without modification, except that the unloading port would have to be sized to allow the accommodation of a wide range of cask cavity diameters. Since the internal cavities of the shipping casks currently being procured by DOE range from less than 20 inches square to 66 inches in diameter, the unloading ports already have a wide range of capability to accept casks of varying internal dimensions and thus should be able to handle the MESC casks with no additional cost being associated with any minor design changes that might be required.

\section{(2) Process Hot Cell}

As noted earlier, the ACD facility hot cells were designed for the handling and processing of individual fuel assemblies and both hot cell space and equipment would have to be added to open the MESCs, remove the fuel assemblies therefrom, and decontaminate the empty MESCs. It was determined that the following additions, modifications, and associated systems would be needed in the process hot cell:

(a) Hot Cell Service Crane; upgrade from 20 tons capacity to 50 tons, to lift the loaded MESCs.

(b) MESC Lifting Grapple(s); unique to MESCs. 
(c) Hot Cell Floor Space; one process hot cell would require widening by approximately 8 feet to accommodate the MESC processing equipment. The $A C D$ did not include a contingency or special purpose hot cell for any sort of non-routine processing operations.

(d) Intercell Transfer Door: required to move MESCs from the canyon cell directiy into the process hot cell. The ACD did not anticipate transferring material directly from the canyon cell into the process hot cell and MESCs would otherwise have to be transferred between the two cells in a shielded cask via the cask receiving bay outside. The transfer door is for operational convenience.

(e) Modify Lag Storage; the ACD lag storage holds approximately 80 MTU of individual PWR or BWR fuel assemblies in removable, interchangeable baskets. The pit requires widening by several inches and rearrangement of the basket support structure to hold the large size MESC. Savings in concrete would probably offset any increase in costs, resulting in little or no incremental cost adjustment for this item, except for some additinoal design work.

(f) MESC Open/Weld Station; required to support, cut and remove closures and seals. The station might also be needed to replace the closures.

(g) Decontamination Station; to clean empty MESCs prior to removal from the hot cell. This function can be combined with item $(f)$ in a machine similar to the R.0. weld/decon station specified in the canyon cell which is used for opening or closing the repository overpacks.

(h) M/S Manipulator; a dedicated master/slave manipulator will be needed adjacent to the work station in items ( $f$ ) and $(g)$.

(i) Shielding Windows; for viewing of MESC operations in the hot cell.

(j) CCTV Viewing Equipment; for viewing of MESC operations.

\section{(3) Lag Storage Vault Cell}

The storage vault cell would be used primarily as a storage facility for MESCs that were not to be immediately opened or to be transferred to a storage cask for MRS. Required revisions to the lag storage vault cell would include the following items:

(a) Service Cranes; upgrade from 35 tons to 50 tons lift capacity. 
(b) MESC Lifting Grapple(s).

(c) Revise Lag Storage: similar to the lag storage pit in the process hot cel1, with no incremental cost incurred.

(d) Revise Vault; to accommodate MESC(s). Like the lag storage pits, there would probably be little, if any, costs incurred since the MESC support baskets would be installed in place of canister baskets during initial construction of the vault.

(e) Lag Storage Vault Decontamination Station: enlarge the size of the existing ACD facility cell decontamination station to accommodate MESCs along with spent fuel canisters or waste packages.

The estimated cost for modifications and additional equipment in the hot cell facilities for MESC transfer and storage are shown in Table 4-18.

\section{TABLE $4-18$}

SUMMARY OF INCREMENTAL RECEIVING AND HANDLING FACILITY COSTS

FOR HOT CELL OPENING AND UNLOADING OF MESCS

$(\$ 000,1988)$

Receiving Bay Equipment

Process Hot Cell

Structure

Equi pment

Electrical/Instrumentation

Lag Storage Vault Cell

Total Direct Costs

Construction Management (10\%)

Engineering (25\%)

Subtotal

Contingency (25\%)

Total Estimated Cost

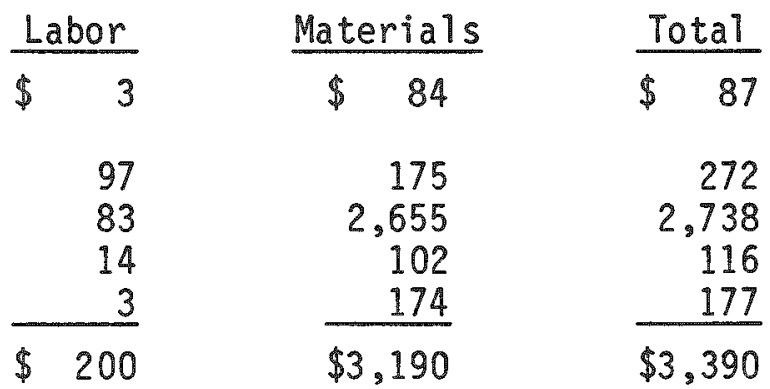

The foregoing costs are fixed costs and would have to be distributed over the total amount of SNF received in MESCs. 
4.2.3.5 Additional Costs of Operations at ACD Facility Receiving and Hot Cell Facilities

In addition to the required capital additions and modifications described in Section 4.2.3.4, some additional operating costs for these facilities will also be incurred as the result of acceptance of spent fuel in MESCS. The principal operating costs associated with handiing MESCs in the ACD facility receiving and handling building (hot cells) were identified as those involving opening the MESCs and removing the fuel, and the disposal of the empty MESCS.

\section{1) Labor}

The labor effort for a 2 person hot cell crew to open and remove the fuel from the 24 PWR assembly and 7 PWR assembly MESCs was estimated to be 35.7 and 33.2 person-hours, respectively. This effort includes bringing the MESC into the process hot cell, cutting and removing the closures, decontamination of the empty MESC and removing it from the hot cell. Using a labor cost of $\$ 65.34 / \mathrm{hr}$. the unit cost for labor would amount to $\$ 0.21 / \mathrm{kgU}$ for a 24 PWR assembly MESC and $\$ 0.67 / \mathrm{kgU}$ for a 7 PWR assembly MESC.

\section{(2) Utilities}

The operating expense for utilities would primarily be the electricity cost in the process hot cell for lights and the ventilation system, which operate continuously, with only a small incremental demand for process equipment. This utility cost is incurred regardless of the number of MESCs received and opened. The utilities cost for the additions to the facility for MESC processing was estimated at \$22-thousand per year, and is applicable from the time the hot cell is placed in service until it is decommissioned.

\section{(3) Maintenance Parts and Supplies}

The cost of maintenance parts and supplies was estimated at \$172-thousand per year, or approximately $3 \%$ of the capital cost of the additional facilities, and was assumed to be incurred regardless of the number of MESCs received and processed -- and is applicable from the time the hot cell is placed in service until it is decommissioned.

Thus, the total additional operating costs that would be incurred in connection with processing MESCs in hot cell facilities would involve a variable cost of $\$ 0.21 / \mathrm{kgU}$ contained in 24 PWR assembly MESCs and $\$ 0.67 / \mathrm{kgU}$ contained in 7 PWR assembly MESCs - plus a fixed annual charge of \$194- 
thousand that would have to be distributed over the total amount of SNF received in MESCs.

\subsubsection{Cost of MRS Casks and Storage Modules}

Figure 4-1 showed two different ways of storage of MESCs in monitored retrievable storage; a vertical MRS concrete storage cask similar to that used in the Parsons ACD of the MRS facility, and a horizontal concrete storage module. The estimated cost of these casks and modules were developed and the change in unit cost for storage modules as a result of storing MESCs was calculated by the difference between the unit costs associated with each of the MESC storage casks and modules, and the unit costs of the casks for storage of consolidated rods and non-fuel components as developed from the Parsons estimates thereof. These are described in the following:

\section{(1) Parsons Cask Costs (14)}

Parsons estimated that the cost of a vertical concrete storage cask for canned fuel rods would be $\$ 220$-thousand (1985 dollars) and would be capable of storing the rods from 36 PWR assembijes. Escalating this cost to 1988 dollars produced a cask cost of $\$ 242-$ thousand, or about $\$ 14.58 / \mathrm{kgU}$ assuming $461 \mathrm{kgU} / \mathrm{PWR}$ assembly.

Parsons also estimated that the cost of a vertical concrete storage cask for non-fuel components would be \$120-thousand (1985 dollars) and would be capable of storing the components from about 150 PWR assemblies. Escalating this cost to 1988 dollars produced a cask cost of $\$ 132$-thousand, or about $\$ 1.91 / \mathrm{kgU}$.

In addition, Parsons allocated a cost of $\$ 12$-thousand/cask for amortization of the capital cost of a cask manufacturing facility based on the cost of the latter being $\$ 15.36-$ million plus 25 percent for overhead and 10 percent for fee - spread over 1,768 casks. Escalating this cost of 1988 dollars produced a cask manufacturing facility cost of about $\$ 23.3-\mathrm{million}$, or about $\$ 13$-thousand/cask. This produced a unit cost of $\$ 0.78 / \mathrm{kgu}$ for casks designed for storing fuel rods, and $\$ 0.45 / \mathrm{kgU}$ for casks designed for storing non-fuel components.

Parsons estimated that the cost of cans for consolidated rods would be about $\$ 4,700$ (1985 dollars) and that the cost of drums for non-fuel components would be about $\$ 520$ (1985 dollars). Escalating this cost to 1988 dollars produced a can cost of $\$ 5,180$ and a drum cost of $\$ 573$-- amounting to $\$ 3.75 / \mathrm{kgU}$ and $\$ 0.12 / \mathrm{kgU}$, respectively, for cans and drums. 
The foregoing costs for vertical concrete storage casks and associated cans and drums are summarized in Table 4-19.

TABLE $4-19$

COST OF MRS CASKS FOR ACD FACILITY

(1988 Dollars!

Description

Casks for Fuel Rods

Cans for Fuel Rods

Casks for Non-Fuel Components

Drums for Non-Fuel Components

Allocation for Cask Manufacturing

Facility Capital Cost

Total
Cost $(\$ / \mathrm{kgU})$

$\$ 14.58$

3.75

1.91

0.12

1.23

$\$ 21.59$

(2) Cost of MESC Storage Casks

Using the same basic costing approach as Parsons used in developing the costs described above, JAI developed estimates of costs for concrete storage casks that were capable of storing one 24 PWR assembly MESC and one, two, and three 7 PWR assembly MESCs. These are summarized in Table 4-20. 
TABLE 4-20

ESTIMATED COSTS OF CONCRETE STORAGE CASKS FOR MESCS

(1988 Dollars)

\section{$\stackrel{\text { Description }}{\mathrm{i}}$}

Cask for 24 PWR Assembly MESC

Cask for 7 PWR Assembly MESC

Cask for 2/7 PWR Assembly MESCs

Cask for $3 / 7$ PWR Assembly MESCs

$\begin{gathered}\text { Capacity } \\ \text { (MTU) }\end{gathered}$
11.06
3.23
6.45
9.68

\begin{tabular}{c} 
Cask \\
Cost \\
$(\$ 000)$ \\
\hline$\$ 207$ \\
120 \\
230 \\
265
\end{tabular}

Allocation of

Cost of Cask

Manufacturing

Fac. $(\$ 000)$

Total

\begin{tabular}{c} 
Cost \\
$(\$ 000)$ \\
\hline
\end{tabular}

$\$ 13$

$\$ 220$

133

243

278
Increase

(Decrease)

Unit in Unit Cost

Cost Over ACD Casks $(\$ / \mathrm{kgU}) \quad(\$ / \mathrm{kgU})$

$\$ 19.89 \quad \$(1.70)$

$41.18 \quad 19.59$

37.67

16.08

28.72

7.13 
(3) Cost of Horizontal Storage Modules

The cost of horizontal storage modules (excluding the MESC), similar to those used by utilities for the storage of MESCs, was estimated at \$106-thousand for a 24 PWR assembiy MESC module and $\$ 65$-thousand for a 7 PWR assembly MESC module -- or $\$ 9.58 / \mathrm{kgU}$ and $\$ 20.14 / \mathrm{kgU}$, respectively. This represented a decrease in unit cost from the ACD concrete cask of $\$ 14.90 / \mathrm{kgU}$ for the 24 PWR assembly MESC module and $\$ 4.34 / \mathrm{kgU}$ for the 7 PWR assembly MESC module.

In addition to the foregoing variable costs, the use of a horizontal storage module would require some capital equipment for unloading the MESCs directly into the module, as described by the following:

(a) It was assumed that the shipping cask would be placed onto a skid and transporter and unloaded directly into the module by pulling the MESC into it. The capital costs estimated for the required equipment are summarized in Table 4-21.

TABLE 4-21

ESTIMATED COST OF EQUIPMENT REQUIRED FOR LOADING MESCS FROM SHIPPING

CASKS INTO STORAGE MODULES AT THE MRS FACILITY

$(\$ 000,1988)$

\begin{tabular}{lr} 
Description & Cost \\
\hline Skid & $\$ 100$ \\
Transporter/Trailer & 250 \\
Ram and Accessories & 100 \\
& 450 \\
Construction Management (10\%) & 45 \\
Engineering (25\%) & 113 \\
& 608 \\
Contingency (25\%) & 152 \\
\multicolumn{1}{|c|}{ Total } & $\underline{760}$ \\
\hline
\end{tabular}

This cost would be incurred immediatly prior to receipt of the first MESCs and would have to be distributed over the total amount of SNF received in MESCS. 
(b) It was also assumed that whenever the MESCs were removed from storage a transfer cask would be required to move the MESCs to the unloading hot cell. This cask was assumed to cost about \$1-million (1988 dollars). Separate casks would be required for the transfer of 24 PWR assembly and 7 PWR assembly MESCs.

The cost of each of these casks would be incurred immediately prior to receipt of the first "MESC of a particular type (24 PWR assembly or 7 PWR assembly MESC), or to the first transfer thereof, and would have to be distributed over the total amount of SNF received in the particular MESC type.

From the foregoing it can be seen that the most cost effective of the vertical MESC concrete storage casks are the 24 PWR assembly MESC cask and the $3 / 7$ PWR assembly MESC cask. The use of horizontal concrete storage modules would be more economical in cases where large quantities of SNF are received in MESCS. Therefore, only these concrete storage casks and modules have been considered further in this study.

\subsubsection{Cost of Additions to Storage Areas}

The reference ACD concrete storage cask has a capacity for storing the fuel rods from 36 PWR assemblies and the non-fuel components cask has a capacity for storing the components from 150 PWR assemblies. This means that an average of 1.24 casks is required to store both the fuel rods and non-fuel components of 36 PWR assemblies. Comparing this with the MESC casks, it would require 1.524 PWR assembly MESC casks or $1.713 / 7$ PWR assembly MESC casks to store 36 PWR assemblies.

The number of additional casks required to store MESCS will depend on the amount of SNF received in MESCs, and can be determined by the following equations:

$$
\begin{aligned}
& N_{24}=\frac{Q_{24}}{(24)(.461)}-\left[\frac{Q_{24}}{(36)(.461)}+\frac{Q_{24}}{(150)(.461)}\right] \\
& N_{21}=\frac{Q_{21}}{(21)(.461)}-\left[\frac{Q_{21}}{(36)(.461)}+\frac{Q_{21}}{T(150)(.461)}\right]
\end{aligned}
$$


where $N_{24}=$ the number of additional 24 PWR assembly MESC casks required to store $Q_{24}$ MTU of SNF contained
in 24 PWR assembly MESCs, $\begin{aligned} & N_{21}= \text { the number of additional } 3 / 7 \text { PWR assembly MESC } \\ & \text { casks required to store } Q_{21} \text { MTU of SNF contained } \\ & \text { in } 7 \text { PWR assembly MESCs. }\end{aligned}$

The ACD storage facility occupies approximately 133 acres with pad space for 1760 concrete casks. If the total number of casks placed in the storage area exceeds 1760, additional space for the pads will have to be provided. The design of the ACD storage area was very conservative in some aspects and there is space available for pads to hold an additional 542 casks without enlarging the area of the site.

The cost of the additional pads can be estimated by the following expression that was developed during the study:

$$
\text { Pad Cost }=\$ 9,982(N)+\$ 15,854
$$

where $N$ is the number of additional casks required. (The last term of the expression is the cost of the ends of the pad which is shared by all of the casks on the pad.)

By combining the formulas described above, the pad cost as a function of quantity of SNF stored in MESCS can be obtained as follows:

$$
\begin{aligned}
& \text { Pad cost }=\$ 9,982\left(.0157 Q_{24}+.0286 Q_{21}\right)+\$ 15,854 \\
& \text { where } Q_{24}=\text { MTU of SNF contained in } 24 \text { PWR assembly MESC casks } \\
& Q_{21}=\text { MTU of spent fuel contained in } 3 / 7 \text { PWR assembly } \\
& \text { MESC casks. }
\end{aligned}
$$

No additional pad costs would be incurred as a result of the use of horizontal storage modules inasmuch as such costs have been included in the construction cost of the modules as set forth in Section 4.2.3.6.

\subsubsection{Additional Cost of Operations in Storage Areas}

Inasmuch as the storage areas would not have to be expanded to accommodate any credible number of MESCs, it is not expected that the cost of lighting, physical security, radiological surveillance and general 
maintenance would change as a result of receipt of SNF in MESCs. However, there is an incremental cost in transferring casks from the receiving and handling facility to the storage area (and retrieving them at the end of their storage period) since more MESC casks are required than reference consolidated fuel casks to store a given amount of SNF. It was determined that the labor involved in moving casks to and from storage was the major variable storage area operating expense and that it was proportional to the number of casks (and MTU of fuel) stored.

It was estimated that about 12 hours of elapsed time and 37 personhours would be required to emplace an ACD consolidated spent fuel cask including a pro-rata share of the time and labor to emplace the cask of associated non-fuel components. This effort includes all activities from moving the empty cask from the cask manufacturing facility into the loading hot cell to placing the cask on a nad in the storage area. For the same activities, the time and labor to load and emplace (or retrieve) several types of MESC storage casks were also determined.

A comparison of the labor required to emplace the consolidated spent fuel cask and the MESC casks, and the added labor cost associated with emplacement of the MESC cask, is shown in Table 4-22.

\section{TABLE 4-22}

\section{CASK EMPLACEMENT EFFORT COMPARISON AND ADDITIONAL LABOR COSTS}

\section{FOR EMPLACEMENT OF A MESC CASK IN STORAGE}

\begin{tabular}{|c|c|c|c|}
\hline Cask Type & $\begin{array}{c}\text { No. } \\
\text { Assemblies }\end{array}$ & $\begin{array}{c}\text { Labor } \\
\text { Person-Hours/ } \\
\text { Cask }\end{array}$ & $\begin{array}{l}\text { Incremental } \\
\text { Labor Costs } \\
(\$ / \mathrm{kg}, 1988)\end{array}$ \\
\hline $\begin{array}{l}\text { ACD Casks (Reference) } \\
24 \text { Assembly MESC Cask } \\
3 / 7 \text { Assembly MESC Cask } \\
1 / 7 \text { Assembly MESC Cask }\end{array}$ & $\begin{array}{r}36 \\
24 \\
21 \\
7\end{array}$ & $\begin{array}{l}37 \\
27 \\
28 \\
27\end{array}$ & $\begin{array}{r}\$ 0.0 \overline{-} \\
0.04 \\
0.40\end{array}$ \\
\hline
\end{tabular}

a Incremental labor cost is the difference between the ACD consol idated spent fuel cask emplacement labor and the MESC cask emplacement labor determined as follows:

$$
\begin{gathered}
\frac{(27 \mathrm{hr})(\$ 65.34 / \mathrm{hr})}{\left(24 \text { Ass }^{\prime} y\right)\left(461 \mathrm{KgU}^{\prime} / \mathrm{Ass}^{\top} \mathrm{y}\right)} \quad \frac{(37 \mathrm{hr})(\$ 65.34 / \mathrm{hr})}{\left(36 \mathrm{Ass}^{\top} \mathrm{y}\right)\left(461 \mathrm{kgU} / \mathrm{Ass}^{\top} \mathrm{y}\right)} \\
=\$ 0.01 / \mathrm{kgU} \text { to emplace a } 24 \text { assembiy MESC }
\end{gathered}
$$


These same incremental costs would also apply to retrieval of the casks from storage and the unloading thereof into the hot cell facilities.

In the case of the use of horizontal storage modules it was assumed that the retrieval cost for a 24 PNR assembly MESC and a 7 PWR assembly MESC would be the same as the retrieval cost for a concrete cask capable of storing these MESCs. However, no incremental emplacement cost would be incurred inasmuch as the direct introduction of the MESC from the shipping cask into the horizontal storage module would, in effect, eliminate the need for first unloading the shipping cask into a hot cell.

\subsubsection{Decommissioning Costs}

It was assumed that the cost of decommissioning hot cell facilities would be 20 percent of the capital cost of the facilities. It was also assumed that the cost of disposal of MESC opening equipment used outside of the hot cell facilities, the concrete storage pads, the MRS concrete casks and horizontal storage modules, and transfer casks would only be about 5 percent of the capital cost thereof inasmuch as none of these items should be seriously contaminated.

\subsubsection{Incremental Life Cycle and Unit Costs for Handing MESCs in FWMS Facilities}

The total incremental ife cycle costs, and incremental unit costs, associated with the receipt of SVF in MESCS was developed for a variety of cases involving ( $i$ ) varying quantities of SNF received in MESCs, (ii) two different MESC types, (iii) both the existence and absence of a MRS facility in the FWMS, and (iv) both opening of the MESCs outside the hot cell facilities and within them. These cost calculations and the assumptions associated therewith have been included in Appendix $E$ and are summarized in izble 4-23. 
TABLE -23

SUMMARY OF INEREMENTAL UNIT COSTS AT FWMS FACILITIES RESULTING

FROM ACCEPTANCE OF SNF IN MESCS

\begin{tabular}{|c|c|c|c|c|c|c|}
\hline & \multirow{2}{*}{$\begin{array}{l}\text { Type of } \\
\text { MESC } \\
\text { Received }\end{array}$} & \multirow{2}{*}{$\begin{array}{c}\text { MRS } \\
\text { Status }\end{array}$} & \multicolumn{2}{|c|}{ MESC Opening Operation } & \multirow{2}{*}{$\begin{array}{l}\text { Total } \\
\text { Quantity SNF } \\
\text { Received in } \\
\text { MESCs (MTU) }\end{array}$} & \multirow{2}{*}{$\begin{array}{c}\text { Incremental } \\
\text { Costs } \\
(\$ / k g u)\end{array}$} \\
\hline & & & Location & Time & & \\
\hline (1) & 24 PWR Assy & With MRS & Outside of hot Cell & Upon Receipt & $\begin{array}{r}564 \\
940 \\
1,504 \\
1,880\end{array}$ & $\begin{array}{r}\$ 3.73 \\
3.42 \\
3.26 \\
3.20\end{array}$ \\
\hline (2) & 24 PWR Assy & No MRS & Outside of Hot Cell & Upon Receipt & $\begin{array}{r}534 \\
890 \\
1,424 \\
1,780\end{array}$ & $\begin{array}{l}3.77 \\
3.45 \\
3.28 \\
3.22\end{array}$ \\
\hline (3) & 7 PWR Assy & With MRS & Outside of Hot Cell & Jpon Receipt & $\begin{array}{r}58 \\
116 \\
232\end{array}$ & $\begin{array}{l}6.31 \\
5.37 \\
4.92\end{array}$ \\
\hline (4) & 7 PWR Assy & No MRS & Outside of Hot Cell & Upon Receipt & $\begin{array}{r}52 \\
104 \\
208\end{array}$ & $\begin{array}{l}6.51 \\
5.46 \\
4.95\end{array}$ \\
\hline (5) & 24 PWR Assy & $\begin{array}{l}\text { With MRS } \\
\text { (Vertical } \\
\text { Concrete } \\
\text { Cask) }\end{array}$ & In Hot Gell & After storage & $\begin{array}{r}564 \\
940 \\
1,504 \\
1,880\end{array}$ & $\begin{array}{r}29.74 \\
17.57 \\
10.68 \\
8.35\end{array}$ \\
\hline (6) & 24 PWR Assy & No MRS & In Hot Cell & After Storage & $\begin{array}{r}534 \\
890 \\
1.424 \\
1.780\end{array}$ & $\begin{array}{l}33.38 \\
20.61 \\
13.44 \\
11.06\end{array}$ \\
\hline$(7)$ & 7 PWR Assy & $\begin{array}{l}\text { With MRS } \\
\text { (Vertical } \\
\text { Concrete } \\
\text { Cask) }\end{array}$ & In Hot Cell & After Storage & $\begin{array}{r}58 \\
116 \\
232\end{array}$ & $\begin{array}{l}43.52 \\
27.18 \\
18.91\end{array}$ \\
\hline (8) & 7 PWR Assy & Vo MRS & In Hot Gell & After Storage & $\begin{array}{r}52 \\
104 \\
208\end{array}$ & $\begin{array}{l}39.17 \\
21.14 \\
12.15\end{array}$ \\
\hline (9) & 24 PWR Assy & $\begin{array}{l}\text { With MRS } \\
\text { (MSM) }\end{array}$ & In Hot Cell & After Storage & $\begin{array}{r}564 \\
940 \\
1,504 \\
1,880\end{array}$ & $\begin{array}{c}18.74 \\
5.42 \\
(2.11) \\
(4.64)\end{array}$ \\
\hline (10) & 7 PUR Assy & $\begin{array}{l}\text { With MRS } \\
\text { (HSM) }\end{array}$ & In Hot Cell & After Storage & $\begin{array}{r}58 \\
116 \\
232\end{array}$ & $\begin{array}{l}48.48 \\
23.42 \\
10.83\end{array}$ \\
\hline (11) & 24 PWR Assy & $\begin{array}{l}\text { With MRS } \\
\text { (HSM) }\end{array}$ & Outside of Hot Celi & After Storage & $\begin{array}{r}554 \\
940 \\
1,504 \\
1,880\end{array}$ & $\begin{array}{l}(9.46) \\
(10.95) \\
(11.86) \\
(12.18)\end{array}$ \\
\hline (12) & PWR ASSY & $\begin{array}{l}\text { With MRS } \\
\text { (HSM) }\end{array}$ & Outside of Hot Cell & After Storage & $\begin{array}{r}58 \\
116 \\
232\end{array}$ & $\begin{array}{r}18.38 \\
8.68 \\
3.75\end{array}$ \\
\hline
\end{tabular}

anit costs are based on the assumption that a PWR assembly contains $461 \mathrm{kgU}$. To obtain the unit cost per assembly regardless of the uranium content thereof. the unit costs in the right hand column must be first multiplied by $461 \mathrm{kgl}$, and then divided by the weight of initial uranium contained in the assembly. 
It should be pointed out that the incremental unit costs shown in the table are based on an allocation of the cost of hot cell facilities, the fixed operating costs associated therewith, the cost of equipment to open the MESCs outside of the hot cell facilities and the cost of HSM loading equipment to the 24 PAR assembly and 7 PAR assembly MESCs. The costs have been based principal1y on the assumption that about 90 percent of the SNF received in MESCS would be in 24 PWR assembly MESCs and the remainder in 7 PWR assembly MESCS. If no SNF were delivered in 7 PWR assembly MESCS, the incremental unit costs associated with the receipt of 24 PWR assembly MESCs would increase from $\$ 0.85-\$ 3.20 / \mathrm{kgU}$ for cases involving handling of MESCs inside of the hot cel1, $\$ 0.05-\$ 0.15 / \mathrm{kglJ}$ for HSM loading equipment for cases where MESCs are stored in HSMS, and $\$ 0.05-\$ 0.20 / \mathrm{kgU}$ for MESC opening equipment for cases where MESCs are opened outside of the hot cell, over the quantity ranges considered. Moreover, for every $10 \%$ reduction in the amount of SNF received in 24 PWR assembly MESCS, the incremental unit costs associated with the receipt of 7 PWR assembly MESCs would increase from $\$ 7.60-\$ 32.30 / \mathrm{kgU}$ for hot cell activities, $\$ 0.40-\$ 1.50 / \mathrm{kgU}$ for HSM loading equipment, and $\$ 0.55-\$ 2.00 / \mathrm{kgU}$ for MESC opening equipment (outside of hot cell), over. the quantity ranges considered.

From the information contained in the foregoing table, the following can be concluded (within the 1 imitations of the assumptions used to develop the contained costs):

(1) The receipt of PWR assemblies in MESCs is more expensive to the FWMS facilities than the receipt of individual PWR assemblies when there is no MRS facility in the system. This is because the MESC has to be cut open prior to removal of the assemblies therefrom and the MESC disposed of.

(2) The cutting of the welds on the lid and shield plug of the MESC while it is in either the shipping cask or an on-site transfer cask is significantly less expensive than opening of the MESC inside a processing hot cell. The former avoids the installation of costly additional hot cell space prior to the initiation of operations at either the MRS facility or repository, and incurring the fixed annual operating costs associated therewith throughout the entire period of operation of the facilities. Instead a much smaller equipment cost is incurred immediately prior to the cutting of the MESC welds.

(3) Regardless of whether thene is a MRS facility in the FWMS or otherwise, the 7 PWR assembly MESCs are more expensive to 
handle in FWMS facilities than are individual PWR assemblies, within the range of quantities considered. While the HSMs used for storage of 7 PWR assembly MESCs in the MRS case are less expensive than the vertical concrete storage casks for storage of consolidated SNF, the resultant savings are never large enough to offset the added costs of handling these MESCS at the MRS facility.

(4) Acceptance of 24 PWR assembly MESCs result in lower costs to FWMS facilities than for individual fuel assemblies provided that (i) there is a MRS facility in the system, (ii) they are received from the utility early enough to be stored at the MRS, (iii) HSMs are used for storage, and (iv) the cutting of the welds on the shielded lid of the MESC is performed outside the hot cell while it is in either the shipping cask or an on-site transfer cask. This is due to the large savings resulting from the use of HSMs for storage of 24 PWR as sembly MESCS that more than offset the other added costs of handling these MESCs at the MRS facility.

(5) Acceptance of 24 PWR assembly MESCs result in lower costs to FWMS facilities than for individual fuel assemblies under the conditions described in (4)( $i),(i i)$, and ( $i i j$, above, even when the MESC is opened inside the process hot cell facilities provided that the total quantities of SNF received in these MESCs is greater than 1300 MTU. This is due to the savings resulting from the use of HSMs for storage of 24 PWR assembly MESCs offsetting the other costs of handling these MESCs at the MRS facility for the larger quantities.

As a result of the foregoing it is clear that the most economical way to handle MESCs at repository facilities would be to cut the weld on the shield plug and lid of the MESC while it is outside the hot cell and in the shipping cask, and to unload the assemblies from the MESC into the hot cell facilities. The incremental unit costs for this as a function of quantity is shown in Items (2) and (4) of Table 4-23.

The most economical way to handle the 7 PWR assembly MESCs at MRS facilities would be the same as described above for receipt of such MESCs at the repository. The incremental unit costs for this as a function of quantity is shown in Item (3) of Table 4-23.

The most economical way to handle the 24 PWR assembly MESCs at MRS facilities would be to transfer them directiy from a shipping cask to HSMs and, after the storage period, to cut the welds on the shielded lid of the MESC while it is in the transfer cask outside the hot cell facilities, and unload the assemblies from the MESC into the hot cell facilities. However, 
this can only be done if the MESCS are received in time to be stored at the MRS facilities. The incremental unit costs for this as a function of quantity is shown in Item (11) of Table 4-23.

If the 24 PWR assembly MESCs are not received in time to be included as part of the SNF in interim storage at the MRS facility, they would have to be handled the same as described above for receipt of MESCs at the repository. The incremental unit costs for this as a function of quantity is shown in Item (1) of Table 4-23.

Cutting the weld on the shielded lid of a MESC while it is still in the shipping or transfer cask should be feasible with minimum radiation exposure of personnel. The cutting fixture would have to be designed to be able to be positioned on the MESC with minimum residence of personnel in the proximity of the cask, and with cutting operation being controlled at a remote station. The MESC will be sealed in this manner at the reactor and thus should be able to be cut open similarly. Moreover, it will be necessary to remove all the cutting chips so that they do not fall into the cask or MESC when the lid is subsequently removed. This could be accomplished using a vacuum follower around the cutting tool, followed by a final cleaning after the cutting is complete. The incremental unit costs included in Table 4-23 should be sufficient to cover the cost of the radiation protection and cleaning operations. 
5.0 SUMMARY OF INCREMENTAL UNIT COSTS TO THE FWMS

A summary of the incremental unit costs to the FWMS resulting from the receipt of SNF in MESCs, for both a system which has a MRS facility included in it and one which does not, is set forth in Tables 5-1 and 5-2. These incremental unit costs are those resulting from the use of special MESC shipping casks that are used to replace some (1 or 2) reference shipping casks in the presently planned DOE fleet and are used exclusively for shipment of MESCs, and the use of the most economical scenarios of handing MESCs in the FWMS facilities.

From the cost data shown in the tables it can be seen that receipt of SNF in MESCS into the FWMS results in cost increases over those which would have been otherwise incurred had the SNF been received in the form of individual PWR assemblies -- except where 900 MTU or more of SNF was received in 24 PWR assembly MESCs in time to store it in MRS facilities (2005 or thereabouts). In a11 cases, the cost of from-reactor transport is higher as a result of the need to include a special-purpose cask to the DOE fleet. However, in the limited instances cited above (where 900 MTU or more of SNF was received in 24 PWR assembly MESCs early enough to commit it to storage in the MRS facility), the cost savings resulting from the use of low cost HSMs more than offset the added cost of shipment. 
TABLE 5-1

ESTIMATED INCREMENTAL UNIT COSTS TO THE FWMS RESULTING FROM RECEIPT OF SNF IN MESCS AT A MRS FACILITY

(1998 Dollars)

Incremental Unit Costs $(\$ / \mathrm{kgU})$

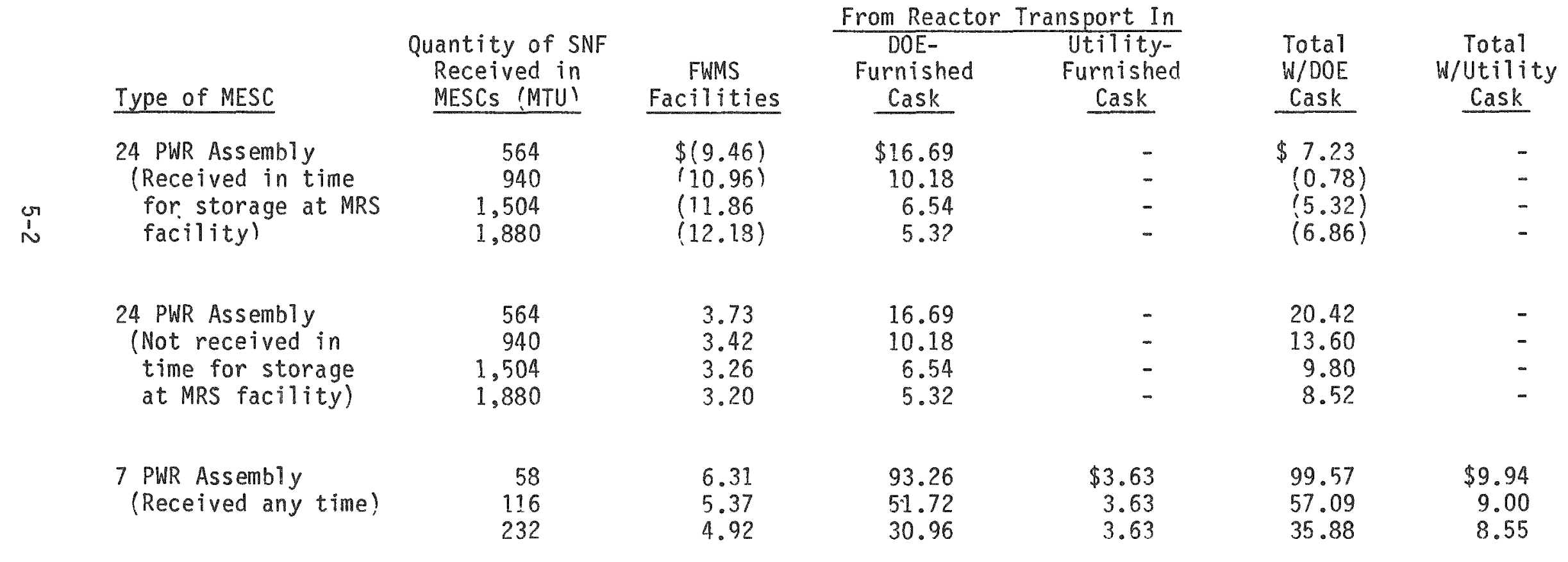

$\overline{{ }^{A} \text { Assumes a } 500-m i l e ~ o n e-w a y ~ s h i p m e n t ~}$ 
TABLE 5-2

ESTIMATED INCREMENTAL UNIT COSTS TO THE FWMS RESULTING

FROM RECEIPT OF SNF IN MESCS AT A REPOSITORY ${ }^{2}$

(1988 Dollars)

Incremental Unit Costs (\$/kgU)

$\stackrel{\vdots}{\omega}$ Type of MESC

24 PWR Assembly

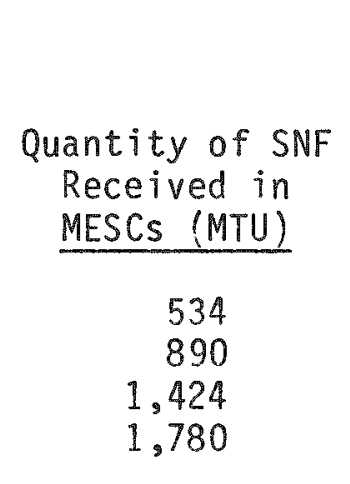

52

1.04

208

\begin{tabular}{c} 
FWMS \\
Facilities \\
\hline$\$ 3.77$ \\
3.45 \\
3.28 \\
3.22
\end{tabular}

$\begin{array}{lr}5.51 & 118.90 \\ 5.46 & 72.58 \\ 4.95 & 49.47\end{array}$

\section{Cask \\ $\$ 24.04$ \\ 14.46 \\ 9.08 \\ 7.30}

$\frac{\text { From Reactor Transport In }}{\text { DOE- Utility- }}$

Furnished Furnished

72.58

49.47
$\$ 13.17$
13.17
13.17

$-$

$-$
Total

W/DOE

Cask

- $\quad \$ 27.81$

17.91

12.36

10.52

$\overline{a_{\text {Assumes a }}}$ 2,800-mile one-way shipment 
The incremental unit costs set forth in the tables are those covering the range of quantities of SNF that could be delivered to DOE in MESCS as a result of firm utility plans to use MESCS. It is not expected that any additional utility usage of 7 PWR assembly MESCs for at-reactor storage will occur, however, additional usage of 24 PWR assembly MESCs may take place. If such does occur, the added costs to the FWMS can be expected to decrease (or the savings to the FWMS can be expected to increase), as follows:

(1) For 24 PWR assembly MESCs that are received by DOE in time for storage in HSMs at the MRS facility -- the savings to the FWMS could amount to as much as $\$ 13 / \mathrm{kgU}$ if 10,000 MTU were so received.

(2) For 24 PWR assembly MESCs, that are not received by DOE in time for storage in HSMs at the MRS facility - the added costs to the FWMS could be as low as $\$ 5-6 / \mathrm{kgU}$, if 10,000 MTU were so received.

(3) For 24 PWR assembly MESCs received at the repository -.. the added costs to the FWMS could be as low as $\$ 6 / \mathrm{kgU}$, if 10,000 MTU were so received.

The relationship of the added costs to the FWMS as a function of the amount of SNF received in MESCS for the three scenarios described above is shown in Figure 5-1. 
FIGURE $5-1$

INCREMENTAL UNIT COSTS TO THE FWMS

RESULTING FROM THE RECEIPT OF SNF IN

MESCS AS A FUNCTION OF THE AMOUNT OF SNF SO RECEIVED

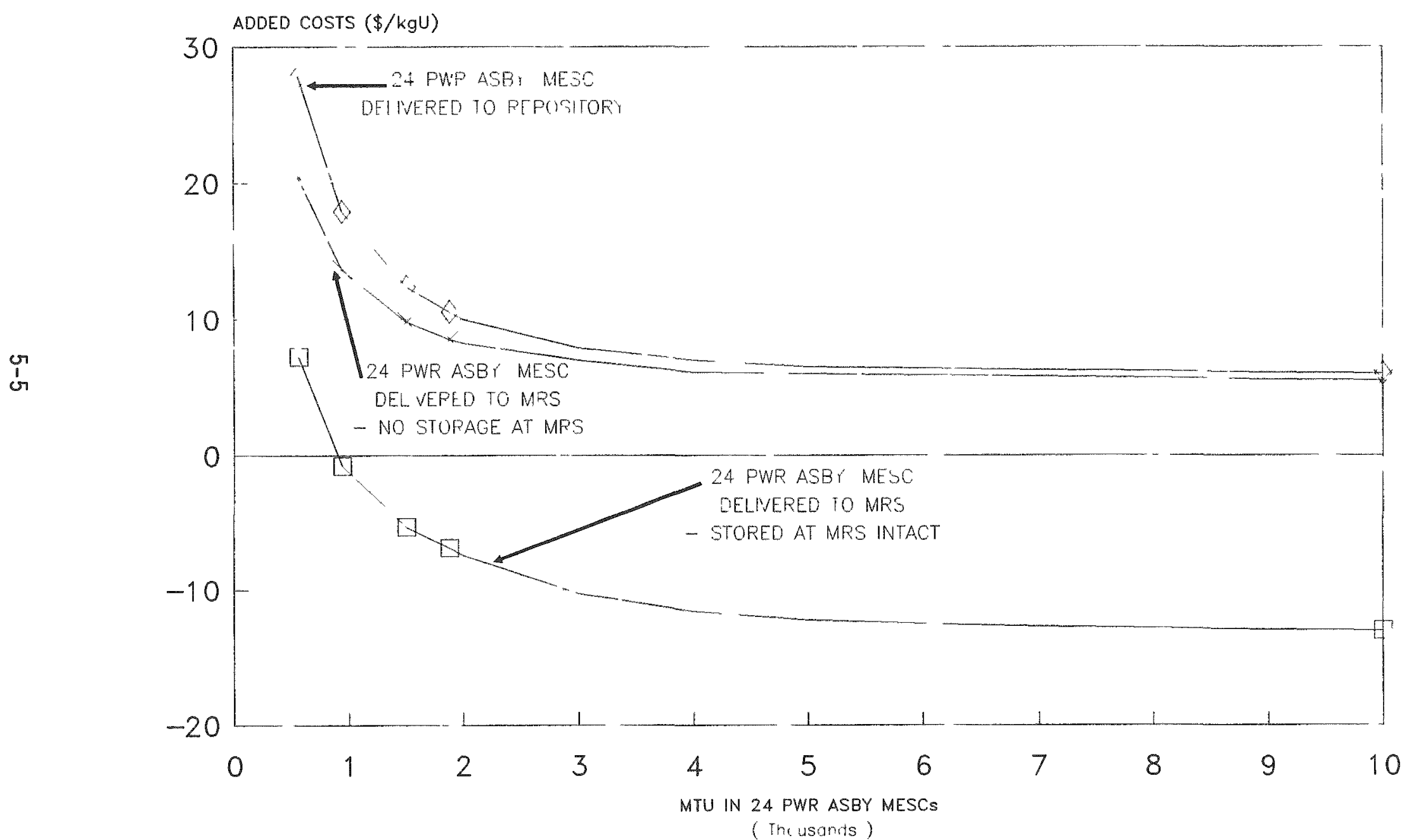


There are several policy alternatives that might be followed by DOE in dealing with the prospective acceptance of SNF in MESCs for transport and disposal. The DOE could either decline to accept SNF in such a form (package) or it could agree to accept it. If it agreed to accept MESCs, it could either do so without charge, or it could charge for the added costs to the FWMS resulting from such acceptance (or provide credits if costs were lower). The intent of this section is to briefly discuss the considerations associated with each of these choices in a balanced way, without advocacy for or opposition to any of the alternatives. It should be pointed out, however, that selection of a policy alternative for dealing with MESC acceptance may have implications for a DOE position regarding other voluntary actions by utilities which decrease their own storage costs, but increase costs to the FWMS.

\subsection{DECLINE TO ACCEPT MESCS}

If DOE were to decline acceptance of SNF in MESCs, the utility would still have the reasonable recourse of opening the MESC at the reactor site, removing the contained assemblies, and loading them into a reference shipping cask. The cost of this to the utility would be only slightly higher than the costs described in Items (1) and (3) of Table 4-23. On the other hand if DOE accepts SNF in MESCs, not only does the FWMS incur these costs, but it incurs significant added transport costs for the MESCs as well. Moreover, overa11 radiation exposure of personnel is not reduced because DOE must open the MESCs at FWMS facilities, unless they are opened inside a hot cell where somewhat less exposure might be expected -- but at significant additional cost. only in the single instance where 24 PWR assembly MESCs are received at a MRS facility early enough to be included in the interim storage inventory does the MESC provide a possible advantage to the FWMS.

The equity implication of this option is that the utility that chooses the MESC option bears the full costs of that option -- none of the costs are shifted to other utilities through the fee. 


\subsection{ACCEPTANCE OF MESCS}

\subsubsection{Acceptance with No Charge For Added Costs}

DOE could agree to accept MESCs the same as it has agreed to accept other fuel forms under the 10CFR961 Standard Disposal Contract within the 1 mill/kWh charge. In establishing this charge, the Nuclear Waste Policy Act made no differential in fee for differences in attributes of the spent fuel or the shipping distance between the individual reactors and DOE facilities. Fuel assemblies vary widely in uranium content and burnup, and these variations can cause wide differences in the cost of transport and disposal of the assemblies. Moreover, the variance in transportation distance can easily make a $\$ 10 / \mathrm{kgU}$ difference in cost as shown in Table 4-14. Thus, it could be argued that acceptance of MESCs, and the absorption of the added costs therefor by the Nuclear Waste Fund, are justified on the basis that the cost increase associated therewith was no greater than the increases already tolerated without adjustment, as a result of:

- a utility delivering 10,000 MWD/MTU burnup fuel compared with one delivering 50,000 MWD/MTU burnup fuel, or

- a utility delivering BWR assemblies each containing $180 \mathrm{kgU}$ compared with one delivering PWR assemblies each containing $460 \mathrm{kgU}$, or

- a utility being 3,000 miles away from the DOE receiving facility compared with one only a few miles away.

On the other hand, it is noted that the receipt of MESCs containing SNF having any single set of characteristics, and shipped over any single distance, would be more costly to the FWMS than the receipt of that same fuel in the form of individual fuel assemblies. Thus, the acceptance of SNF in MESCs with no charge for the added costs to the FWMS is, in effect, a subsidy for the use of that storage option relative to other options. Further, the cost increase to the FWMS for delivery of a MESC would be a discretionary one to the utility, in the sense that the utility could also deliver individual assemblies without a cost increase to the FWMS. There is clearly an important utility equity issue involved --whether a utility should be able to save costs at its reactor site as a result of not having to open the MESCs, at the expense of all users of the FWMS. It may be arguable that the established precedent 
of accepting other cost increases without fee adjustment does not apply because the other increases are not discretionary to the same degree as the delivery of MESCs.

\subsubsection{Acceptance with A Charge For Added Costs}

DOE could establish a surcharge for receipt of SNF in MESCs to cover the added costs to the FWMS as a result thereof, as follows:

(1) Separate charges (or credits) could be established for the 24 PWR and 7 PWR assembly MESCs, for a FWMS that contains a MRS facility and for one that does not, and for delivery of 24 PWR assembly MESCs in time to be included in interim storage at a MRS facility. For each of the foregoing instances the charges (or credits) could be established as a function of the quantity of SNF received in a given type of MESC. These charges would be similar to those set forth in Tables 5-1 and $5-2$.

(2) Whenever a utility decides to use MESCs for storage at its reactor site, and wants to guarantee acceptance thereof by the FWMS for the then-prevailing charges (or credits), it would be required to (i) notify the DOE of its plans, (ii) submit a description of the MESCS and their contents to DOE for acceptance approval, and ( $i$ ii) commit to deliver a specific quantity of SNF to DOE in MESCS. Upon DOE approval of the MESC description, the DOE charge (or credit) schedule then prevailing for the total quantity of SNF committed to be delivered to DOE in MESCs to that point in time would be applicable and would not be subject to change thereafter except as a result of escalation using a specifically identified index. In this way, the utility would be able to fully evaluate the economic aspects of using MESCs for storage at the reactor site prior to committing SNF to storage there in -- the charge (or credit) would be fixed based on when the commitment was made and subject only to escalation. A utility could decide to provide such notification and delivery commitment at any time, but it would be at risk with respect to DOE approval and delivery of the DOE-approved MESCs would be subject to the charge (or credit) schedule applicable at the time of its commitment.

(3) Whenever a utility has committed to deliver a fixed amount of SNF in MESCs at the then prevailing charge (or credit) for the total quancities committed to DOE (including the utility's commitments), and further commitments are subsequentiy received by DOE from others for delivery of the same MESC type, the utility would be due an adjustment in charges (or credits) as follows: 
(a) If the additional commitments were made under the same charge (or credit) schedule -- the charge (or credit) schedule applicable to the delivery of the utility's MESCs would be reduced to that applicable for the total quantities committed.

(b) If the additional commitments were made under a revised charge (or credit) schedule -- the charge (or credit) schedule applicable to delivery of the utility's MESCs would be the lower of:

(i) the charge (or credit) schedule prevailing at the time of the utility's commitment that is applicable to all such commitments received to the time of the commitment (including that of the utility's)

(ii) the charge (or credit) schedule prevailing at the time the additional commitments were made (including the additional commitments).

(4) Until such time as a decision is finally made regarding whether or not a MRS facility is to be included in the FWMS, the charge (or credit) schedule applicable to the repository would be applicable. If it is finally determined that a MRS facility is to be included in the FWMS, the schedule of charges (or credits) applicable to delivery of MESCs to the repository would be discontinued. However, if it is determined that no MRS facility is to be included in the FWMS, the schedule of charges (or credits) applicable to delivery of MESCs to a MRS facility would be discontinued.

(5) From time to time, DOE could review the costs associated with receipt of MESCs into the FWMS and modify its schedule of charges (or credits) to reflect changes in costs for FWMS transportation equipment and facilities, and the operation thereof. Included in these cost changes would be any additional costs or savings resulting from the difference between the charges (or credits) applicable to earlier commitments and the current estimates of charges (or credits) therefor.

\subsubsection{Conditions of Acceptance}

The acceptance of SNF in MESCS would be subject to the following conditions:

(1) The design of the MESC shall be subject to the approval of DOE for acceptance. The utility shall submit a full set of drawings, specifications and other descriptive material so as to provide DOE with a description that is sufficiently complete and accurate to permit DOE to properly evaluate the impact of receipt of the MESC on the FWMS transportation system and facilities. 
(2) The MESCs delivered by a utility shall meet the specifications approved by DOE in (1), above, within the tolerances set forth in the specifications and must contain only intact and nondefective SNF assemblies. At the time of delivery of the MESC shipment to DOE, the utility shall provide a written certification that the foregoing requirements have been met.

(3) The utility shall have a capability to receive and handle DOEfurnished shipping casks for MESCs having the following maximum weights, excluding the weight of MESC and contained SNF:

(a) For a 24 PWR assembly MESC shipping cask

On transport vehicle 105 tons

On reactor crane hook 87 tons

(b) For a 7 PWR assembly MESC shipping cask

on transport vehicle 61 tons

On reactor crane hook 49 tons

(4) Alternatively to (3) the utility may deliver MESCS to DOE in utility-furnished shipping casks provided:

(a) The shipment is fully certified by NRC

(b) The MESCs are delivered in full conformance to the other conditions set forth herein

(c) No payments shall be due the utility by DOE for use of the cask.

The design of the utility-furnished shipping casks shall be subject to the approval of DOE. The utility shall submit a full set of drawings, specifications and other descriptive material so as to provide DOE with a description that is sufficiently complete and accurate to permit DOE to properly evaluate the impact of receipt of MESCs in the cask on the FWMS transportation system and facilities.

(5) The DOE or its designated representative shall have been present to witness the loading of the MESC and the sealing thereof unless DOE specifically waives its right to do so.

(6) The MESC, when loaded into the DOE-furnished or utilityfurnished shipping cask, shall be capable of being removed readily therefrom either by lifting vertically out of the cask or by pulling it out in a horizontal position into a horizontal storage module. The utility shall supply any special handling tools that are required for such removal.

(7) The MESC, when loaded into the DOE-furnished or other utilityfurnished shipping cask, shall constitute a certified shipment 
under NRC regulations. The utility shall have the responsibility to apply for and obtain NRC approval for use of the MESC in connection with the shipping cask without cost to DOE.

(8) Delivery of the 24 PWR assembly MESCs to a MRS facility shall be effected no later than December 31, 2005, in order to qualify for the credits set forth in Table 5-1 for delivery in time for storage at the MRS facility.

\subsection{SUMMARY OF ALTERNATIVES}

This Section 6.0 has outlined the three basic alternatives for dealing with the prospective acceptance of SNF in MESCs. The basic issues that must be addressed arise because the acceptance of MESCs direct7y increases FWMS costs, and hence the collective costs shared by all utilities. Further, such cost increases are at the discretion of the individual utility delivering the MESCs, which has the viable alternative of delivering fuel assemblies. The discretionary nature of this cost increase directly raises the issue of inter-utility equity, and the three alternatives deal with this issue in the following ways:

(1) DOE declines to accept MESCs. This approach avoids the issue of inter-utility equity by foreclosing the possibility of incurring MESC-related cost increases in the FWMS.

(2) DOE accepts MESCs without charge for added costs (or credits). This approach implicitly accepts and tolerates any interutility inequity that may be incurred.

(3) DOE accepts MESCs with payment for added costs (or credits for avoided costs). This approach avoids inter-utility inequities by charging the full amount of the increased costs that are incurred.

It should be emphasized here that any alternative that shifts costs of any spent fuel management option from the individual utility to the FWMS, subsidizes the option and, therefore, encourages its use over other avaitable options. 
7.0 REFERENCES

(1) Title 10, Code of Federal Regulations, Part 961

(2) U. S. Nuclear Regulatory Commission, Commission Briefing on Cask Designs for Shipping and Storage of Nuclear Materials (Transcript), October 19, 1988

(3) Electric Power Research Institute, NUHOMS Spent-Fuel Storage Demonstration: Program Overview, EPRI NP-5174, ApriT 1987

(4) Pacific Northwest Laboratory, Commercial Spent Fuel Management Program Monthly Progress Report, PNL-4947-58, July 1988

(5) R. W. Rasmussen, Status of Concrete Storage Module Concept for AtReactor Storage, Proceedings of INMM Spent Fuel Management Seminar $V$, Washington, D.C., January 20-22, 1988

(6) Duke Power Company/NUTECH, NUHOMS Horizontal Modular Storage System, Presentation to DOE at Spent Fuel Systems Interface Meeting, September 19,1988

(7) Duke Power Company, Safety Analysis Report, Independent Spent Fuel Storage Installation, submittal to NRC

(8) U. S. Department of Energy, Dry Cask Storage Study, DOE/RW-0196, December 1988

(9) Letter J. A. Tiernan (BG\&E) to Charles Head (DOE), dated October 27, 1988

(10) H\&R Technical Associates, Inc. and E. R. Johnson Associates, Inc. Use of Transportable Storage Casks in the Nuclear Waste Management system, ORNL/SUb/85-SA094, December 1987

(11) Chem-Nuclear Systems Inc., Barnwell Low-Level Radioactive Waste Management Facility Rate Schedule, effective January 15, 1988

(12) The Raiph M. Parsons Company, Integral Monitored Retrievable Storage (MRS) Facility Conceptual Design Report, MRS-11, JuTy 1985

(13) Sandia National Laboratories, Site Characterization Plan Conceptual Design Report, SAND84-2641, September 1987

(14) E. R. Johnson Associates, Inc., Results of Preliminary Analysis of Differences in MRS Facil ity Costs Between the DOE MRS Facility Design And That Contained in the Draft JAI PRDA Report, JAI-263, October 1985 
8.0 DEFINITIONS

(1) "SNF" means spent nuclear fuel

(2) "FWMS" means the Federal Waste Management System as described in Figure 2-1 of the U.S. Department of Energy, Draft 1988 Mission Plan Amendment, DOE-RW-0187, June 1988

(3) "FWMS facilities" means the fixed-base facilities associated with the FWMS (excludes shipping cask, and maintenance and support facilities therefor)

(4) "PWR" means pressurized water reactor

(5) "MRS" means monitored retrievable storage

(6) "MRS faclility" means a facility that is independently located from a repository site that receives, stores, and processes and/or packages SNF. SNF received at a MRS facility will be subsequently shipped to a repository for disposal.

(7) "HSM" means a horizontal concrete module that can be used to store MESCs

(8) "MESCs" means multiple element sealed canisters. A MESC is generally cylindrical in shape and contains either 7 or 24 PWR assemblies positioned in an orthogonal array in a basket assembiy

(9) "ACD" means the advanced conceptual design of a MRS facility that was prepared in 1985 by The Ralph M. Parsons Company (Reference 12).

(10) "Consolidated fuel rods" means fuel rods that have been removed from their original assembly structure and packaged in a high density array

(11) "Consolidated fuel" means fuel rods and compacted structural parts.

(12) "MTU" means metric tons of uranium contained in the fuel prior to introduction into the reactor $(1,000 \mathrm{~kg}$ or $2,205 \mathrm{ib})$. 
APPENDIX A

LIFE CYCLE TRANSPORT COSTS AND UNIT COST CALCULATIONS ASSOCIATED WITH THE USE OF A SINGLE REFERENCE SHIPPING CASK

OR MESC SHIPPING CASK -- CASKS FULLY UTILIZED EITHER EXCLUSIVELY FOR SHIPMENT OF INDIVIDUAL PWR ASSEMBLIES OR FOR MESCS CONTAINING PWR ASSEMBLIES 
APPENDIX A

LIFE CYCLE TRANSPORT COSTS AND UNIT COST CALCULATIONS

ASSOCIATED WITH THE USE OF A SINGLE REFERENCE SHIPPING CASK

OR MESC SHIPPING CASK - - CASKS FULLY UTILIZED EITHER

EXCLUSIVELY FOR SHIPMENT OF INDIVIDUAL PWR ASSEMBLIES OR

FOR MESCS CONTAINING PWR ASSEMBLIES

The total life cycle costs associated with the use of a single reference shipping cask and MESC shipping casks for shipments from reactors to DOE facilities were developed for the following cases, assuming that the casks would be used either exclusively for shipment of individual PWR assemblies or exclusively for MESCs containing PWR assemblies:

Case 1 -- Transport of 21 PWR Assemblies in a Reference Shipping Cask

Case 2 -- Transport of 24 PWR Assembly MESCs in a MESC Shipping Cask (One MESC Cask in DOE Fleet)

Case 3 -. Transport of 24 PWR AssembIy MESCs in a MESC Shipping Cask (Two MESC Casks in DOE Fleet)

Case 4 -- Transport of PWR Assemblies in a 24 PWR Assembly MESC Shipping Cask (One MESC Cask in DOE Fleet)

Case 5 -- Transport of PWR Assemblies in a 24 PWR Assembly MESC Shipping Cask (Two MESC Casks in DOE Fleet)

Case 6 -- Transport of 7 PWR Assembly MESCs in a 7 PWR Assembly MESC Shipping Cask (One MESC Cask in DOE Fleet)

Case 7 -- Transport of 7 PWR Assemblies in a 7 PWR Assembly MESC Shipping Cask (One MESC Cask in DOE Fleet)

Case 8 -. Transport of $2 / 7$ PWR Assembly MESCs in a $2 / 7$ PWR Assembly MESC Shipping Cask (One MESC Cask in DOE Fleet)

Case 9 -- Transport of 26 PWR Assemblies in a 2/7 PWR Assembly MESC Shipping Cask (One MESC Cask in DOE Fleet) 
For each of the foregoing cases, life cycle costs were developed for transport over distances of 500 miles and 2800 miles (one-way). These are designated subcases $A$ and $B$, respectively for each of the cases described above.

The life cycle costs and resulting unit costs for each of the foregoing cases are shown in Tables A-1 through A-18. The figures set forth in the tables were developed as follows:

(1) The total costs were assumed to be incurred over the period 1997 to 2023, inclusive. During the period 1997 through 2002 the capital cost of the cask would be incurred; during the period 2003 through 2022 the cost of operations, freight and escorts would be incurred; and in 2023 the cost of decommissioning would be incurred.

(2) With regard to the capital cost of the cask, it was assumed that the cost of design and development would be incurred in 1997, the cost of model fabrication and testing would be incurred in 1998, the NRC Certification Fee would be paid in 1999, half of the cost of cask fabrication would be incurred in 2001, and the other half of the cost of fabrication plus the cost of acceptance testing and auxiliary equipment would be incurred in 2002. It was assumed that 1999 and 2000 would be required by NRC to make the necessary safety reviews, and that certification would be made at the end of 2000 .

(3) The annual quantities shipped each year were assumed to be as follows:

Cask Type

Reference Rail Cask

24 PWR Assembiy MESC Cask

24 PWR Assembly MESC Cask

7 PWR Assembly MESC Cask

7 PWR Assembly MESC Cask

2/7 PWR Assembly MESC Cask

2/7 PWR Assembly MESC Cask
Form of

Fuel Shipped

Assembities

MESCS

Assemblies

MESCS

Assemblies

MESCS

Assemblies
Annual Quantity

MTU in single

Shipment

9.68

11.06

11.06

3.23

3.23

6.45

11.99
Shipped (MTU)

$500 \quad 2800$

Miles Miles

174

77

188*

89

199

89

$55^{*}$

26

58

26

110 *

52

216

a Based on 18 shipments/year for 500-mile shipments $(17$ shipments/year for those cases marked with an asterisk), and 8 shipments/year for 2800-mite shipments. 
(4) The annual cost of operation, freight, escorts and decommissioning were determined as described in Section 4.1.2.3.

(5) The total costs were discounted by $3 \% /$ year to 1988 to get the total discounted costs.

(6) The unit costs were determined by dividing the total discounted costs by the total discounted amount (MTU) of spent. fuel shipped, as follows:

Discounted Costs $=$ Discounted (Unit Costs $\times$ MTU Shipped)

Discounted Costs $=$ Unit Costs $\times$ Discounted MTU Shipped

Unit Cost $=$ Discounted Costs Discounted MTU Shipped

A more detailed explanation of the methodology used for the unit cost calculation is set forth in Appendix $F$. 
TAML: A-1

CASE IA -- LIFE CYCLE COSI OF IRAHSPORT OF PUR ASSEMBLES YROA REACTORS PO DOE FACILITIES 500 MILES AUAY IH 21 PUP ASSEHLLY REPEREMCE SHIPPIHG CASI

(10 CASUS IH FLETI)

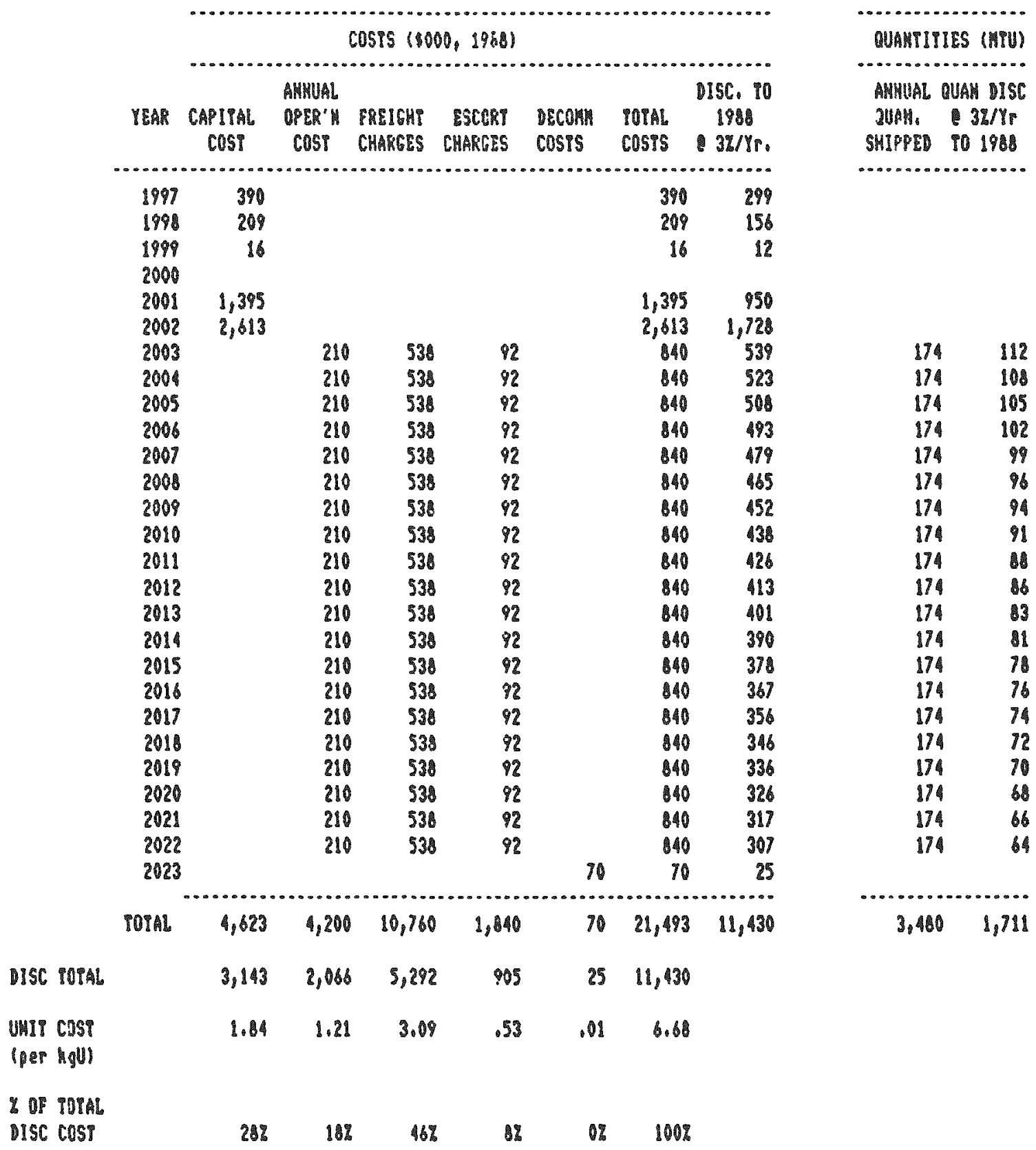


IABLE A-?

CASE IR - LIFE CYCLE COST OF TRAMSPORI OF PUR AJSEMBLIES PROR REACTORS TO DOE PACHLIYIES 2000 MILES AUAY IU A 21 PUR ASEEMBLY REPEREMCE SHIPPING CASW

(10 CASPS: : PLERT)

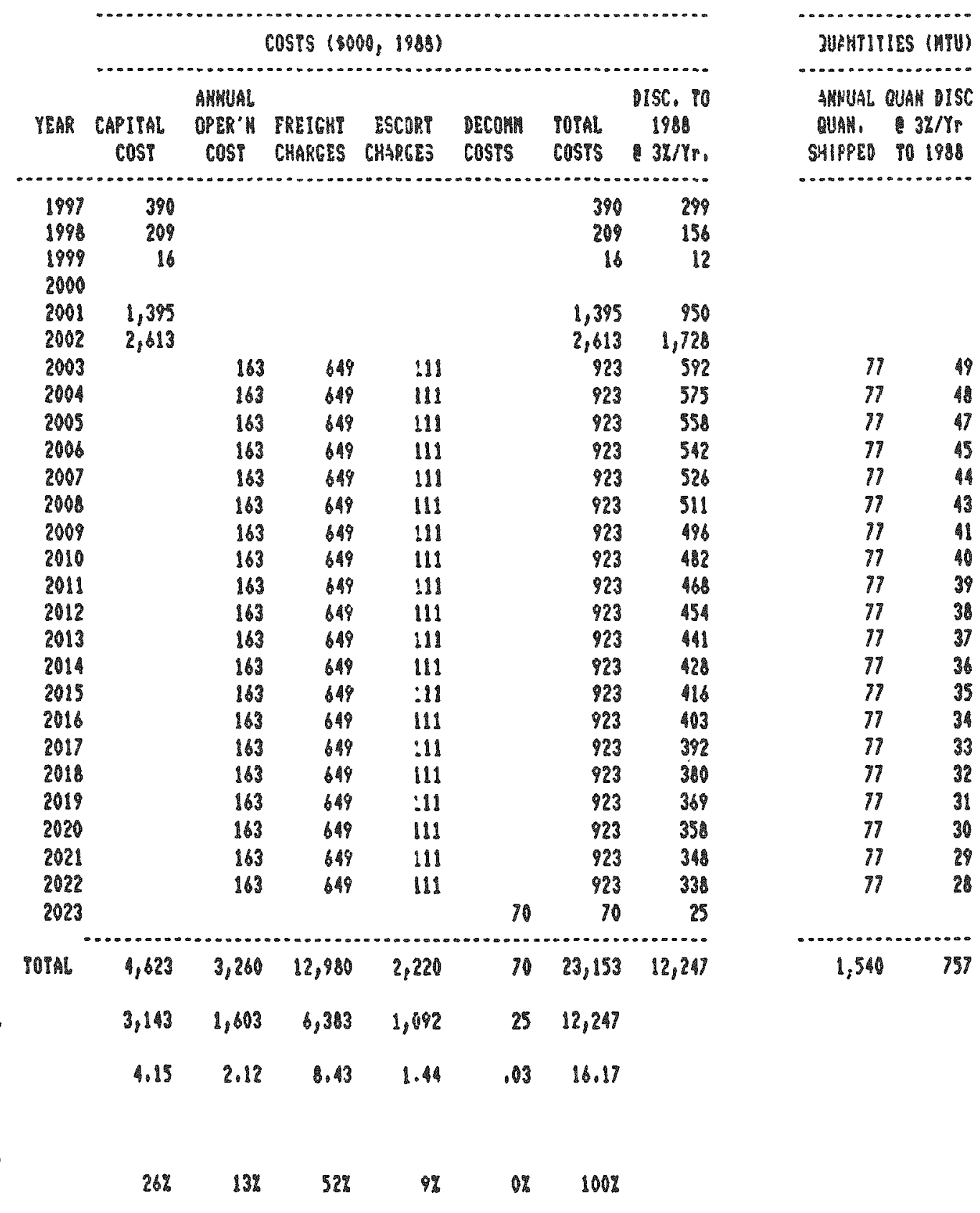


PALLE Aิ-3

CASE 2A - - LIFE CYCLE COSP OF TRAMSPORT OF 24 PME ASSEMBLY MESCS PROM REACTORS PO DOE PACILITIES 500 WILES AUAY IN A MESC SHIPPIHG CAS (ONE MESC CAST IN PLEET)

\begin{tabular}{|c|c|c|c|c|c|c|c|c|c|c|}
\hline & & ............. & $\cdots$ & cosps ib & $00,1988)$ & n........ & n....... & n........ & Quanti? & IES (MTU) \\
\hline & YEAR & $\begin{array}{c}\text { CAPITAL } \\
\text { COSI }\end{array}$ & $\begin{array}{l}\text { AKWUAL } \\
\text { OPER' } \\
\text { COSP }\end{array}$ & $\begin{array}{l}\text { PREIGKT } \\
\text { CHARGRS }\end{array}$ & $\begin{array}{r}\text { ESCORT } \\
\text { CHARGES }\end{array}$ & $\begin{array}{l}\text { Decomen } \\
\text { costs }\end{array}$ & $\begin{array}{l}\text { TOTAL } \\
\text { COSTS }\end{array}$ & $\begin{array}{l}15 C_{8} 90 \\
1988 \\
\text { s\%/Y }\end{array}$ & $\begin{array}{l}\text { ABWHAL } \\
\text { QUAN. } \\
\text { SHIPPED }\end{array}$ & $\begin{array}{l}\text { Quan DISC } \\
\text { 3L/YP } \\
\text { T0 1988 }\end{array}$ \\
\hline & 1997 & 993 & & & & & 99 & 961 & & \\
\hline & $\begin{array}{l}1991 \\
1890\end{array}$ & 2,7918 & & & & & 2,798 & 2,101 & & \\
\hline & 1999 & 804 & & & & & 184 & 133 & & \\
\hline & 2000 & & & & & & & & & \\
\hline & 2001 & 1,937 & & & & & 1,437 & 1, 319 & & \\
\hline & 3002 & 3,472 & & & & & 3,472 & 2,895 & & \\
\hline & 2003 & & 205 & 552 & 8 & & 844 & 542 & 18 & 121 \\
\hline & 2004 & & 205 & 552 & 87 & & 844 & 526 & 188 & 117 \\
\hline & 2005 & & 205 & 552 & 87 & & 844 & 511 & 188 & 114 \\
\hline & 2006 & & 205 & 552 & 17 & & 144 & 496 & 188 & 110 \\
\hline & 2007 & & 205 & 552 & 87 & & 84 & 481 & 186 & 107 \\
\hline & 2008 & & 205 & 552 & 87 & & 844 & 487 & 188 & 104 \\
\hline & 2009 & & 205 & 552 & 7 & & 844 & 454 & 180 & 101 \\
\hline & 2010 & & 205 & 552 & 8 & & 844 & 140 & 188 & 9 \\
\hline & 2011 & & 205 & 552 & 87 & & 844 & 428 & 180 & 95 \\
\hline & 2012 & & 205 & 552 & 87 & & 844 & | 15 & lest & 92 \\
\hline & 2013 & & 205 & 552 & 87 & & 844 & 403 & 180 & 90 \\
\hline & 2014 & & 205 & 552 & 87 & & 841 & 391 & 188 & 87 \\
\hline & 2015 & & 305 & $55 ?$ & 87 & & 844 & 380 & 180 & 85 \\
\hline & 2016 & & 205 & 552 & 7 & & 844 & 369 & 188 & 2 \\
\hline & 2017 & & 205 & 552 & 87 & & 844 & 351 & 108 & 80 \\
\hline & 2018 & & 205 & 552 & B7 & & 844 & 348 & 118 & $n$ \\
\hline & 2019 & & 205 & $55 ?$ & 87 & & 844 & 336 & 106 & 75 \\
\hline & 2020 & & 205 & 552 & है & & 844 & 328 & 188 & 73 \\
\hline & 2021 & & 205 & 552 & 87 & & 844 & 316 & jol & 71 \\
\hline & 2022 & & 205 & 552 & 8 & & 844 & 309 & 108 & 6 \\
\hline & 2023 & & & & & 84 & 14 & 30 & & \\
\hline & TOIAL & 9,364 & 4,100 & 11,040 & 1,740 & 84 & 23,34 & 14,922 & 3,760 & 1,84 \\
\hline MSC PDTAL & & 8,590 & 2,016 & 5,129 & 856 & 30 & 14,922 & & & \\
\hline $\begin{array}{l}\text { UMII COST } \\
\text { (ger haUU }\end{array}$ & & 3.56 & 1.09 & 2.91 & .46 & .02 & 8.07 & & & \\
\hline - OF PDIAL & & & & & & & & & & \\
\hline ISC Cost & & 442 & 148 & $36 \%$ & $b \%$ & $0 \%$ & $1001 \%$ & & & \\
\hline
\end{tabular}


TALLE A- A

CASE 2. - LIPE CYCLE COSI OF TRAMSPORT OE 24 PU: ASSEHBLY HESCS FRON REACFORS PO DOE FACILIYISS

2800 HILES AMAY IN A HESC SHIPPIHG CASI

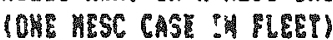

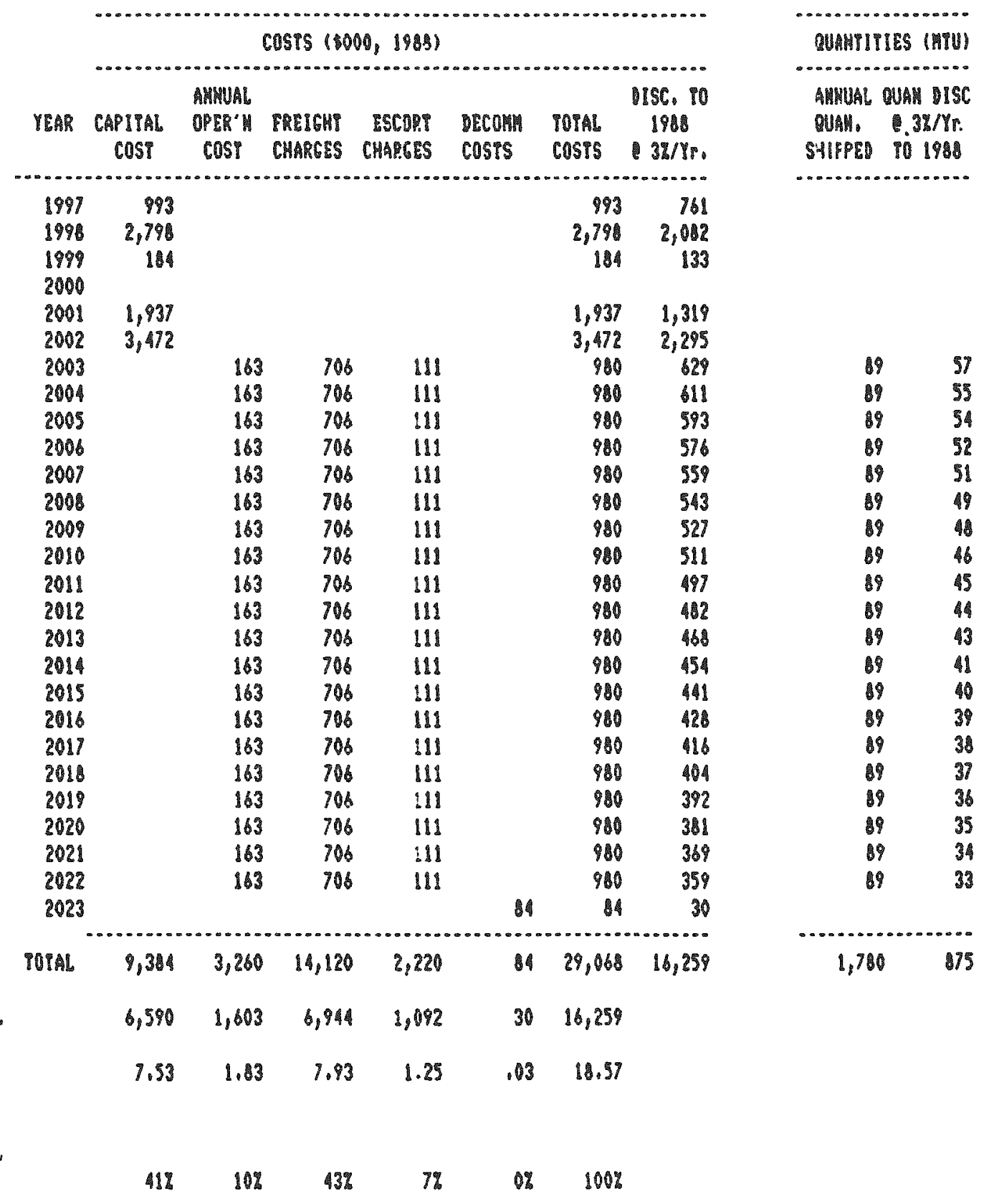


IABS: A-S

CASE 3A - LIPE CYCLE COSY OF TKAMSFOR OF 24 PUR ASSEMBLY HESCS RROH REACTORS TO DOE FACIIITISE 300 HILES AHAY IN A MESC SHIPPING CASL

(TWO HESC CASIS IN PLERT)

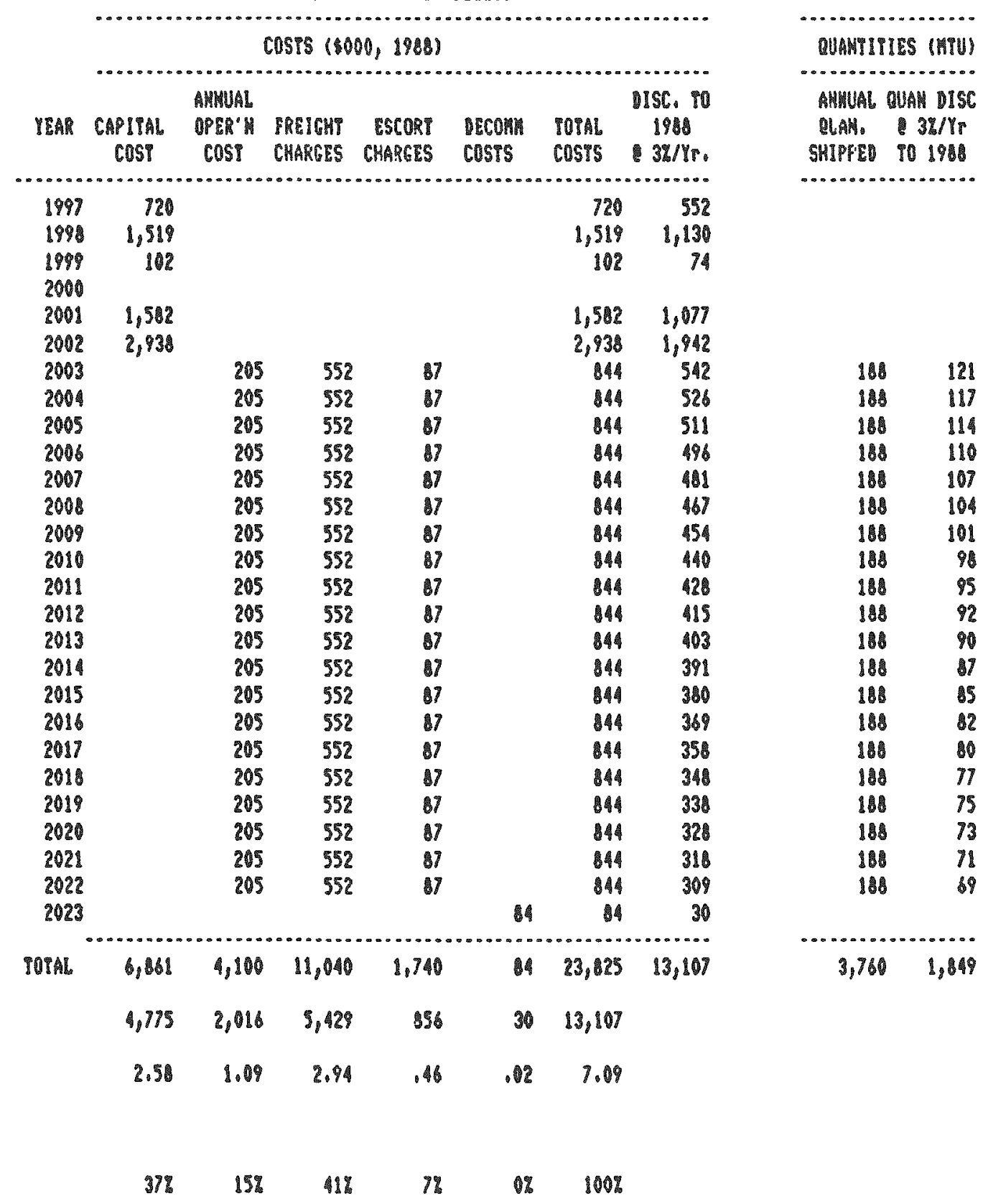


IABSE A-

CASE 31 - LIFE CYCLE COSI OF IRAMSPOR OP ZI PUR AESEMBLY MESCS FRON REACYORS TO DOE PACILIISE 2800 WILES MUAY IH HESC SHIPPING CASE

(IUO MESC CASMS IN PLETI

costs $(1000,1980)$

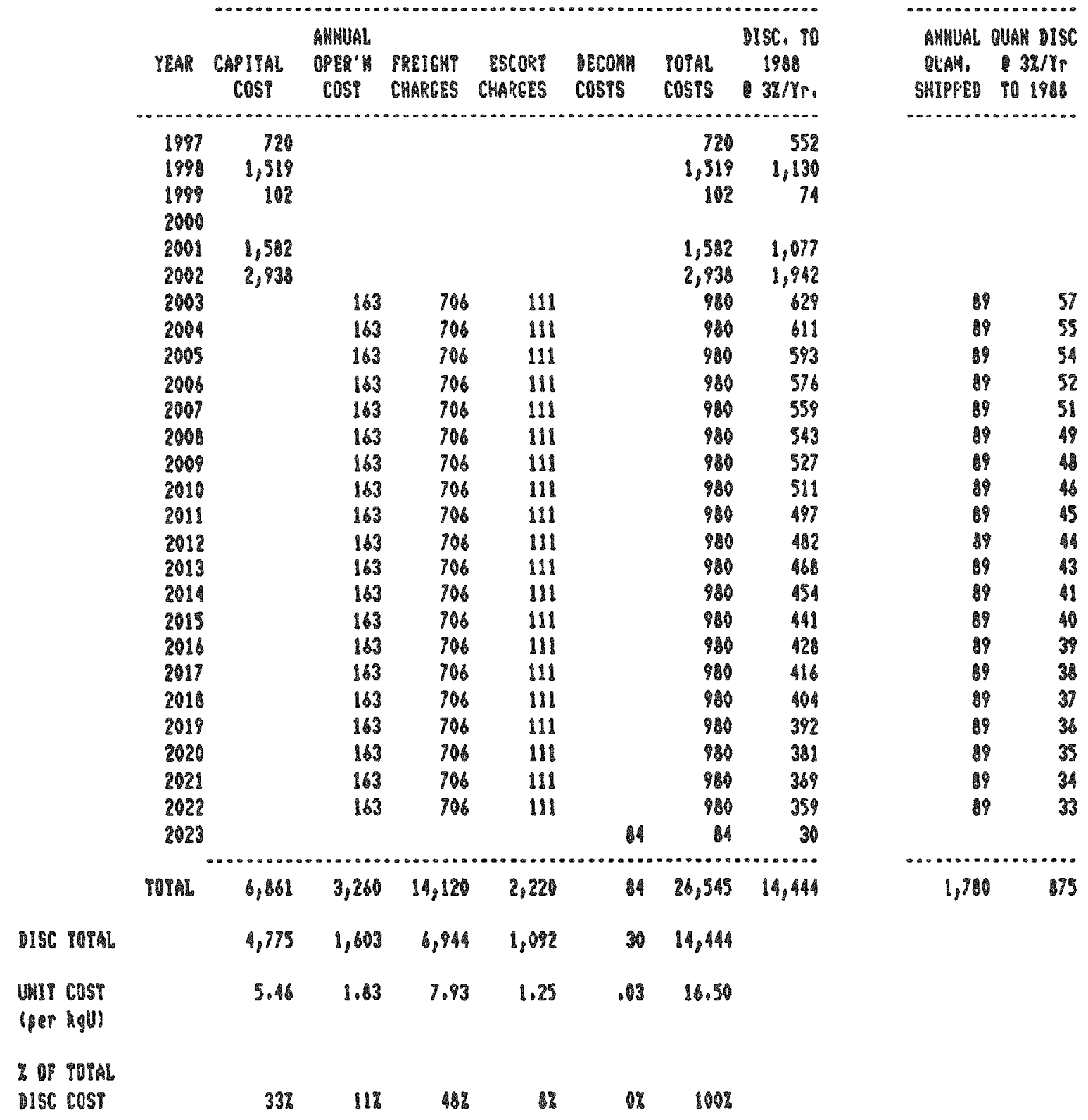

QUAMTIIISS (ITU)

AMHUAL OUAN ISC

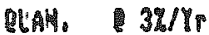

SHIPFE 101908 
TABLE A-7

CASE

SOO HILES AHAY IN 24 PUR ASSEMULY MESC SHIPPIUG CAST (ONE WESC CASS IN PICEY)

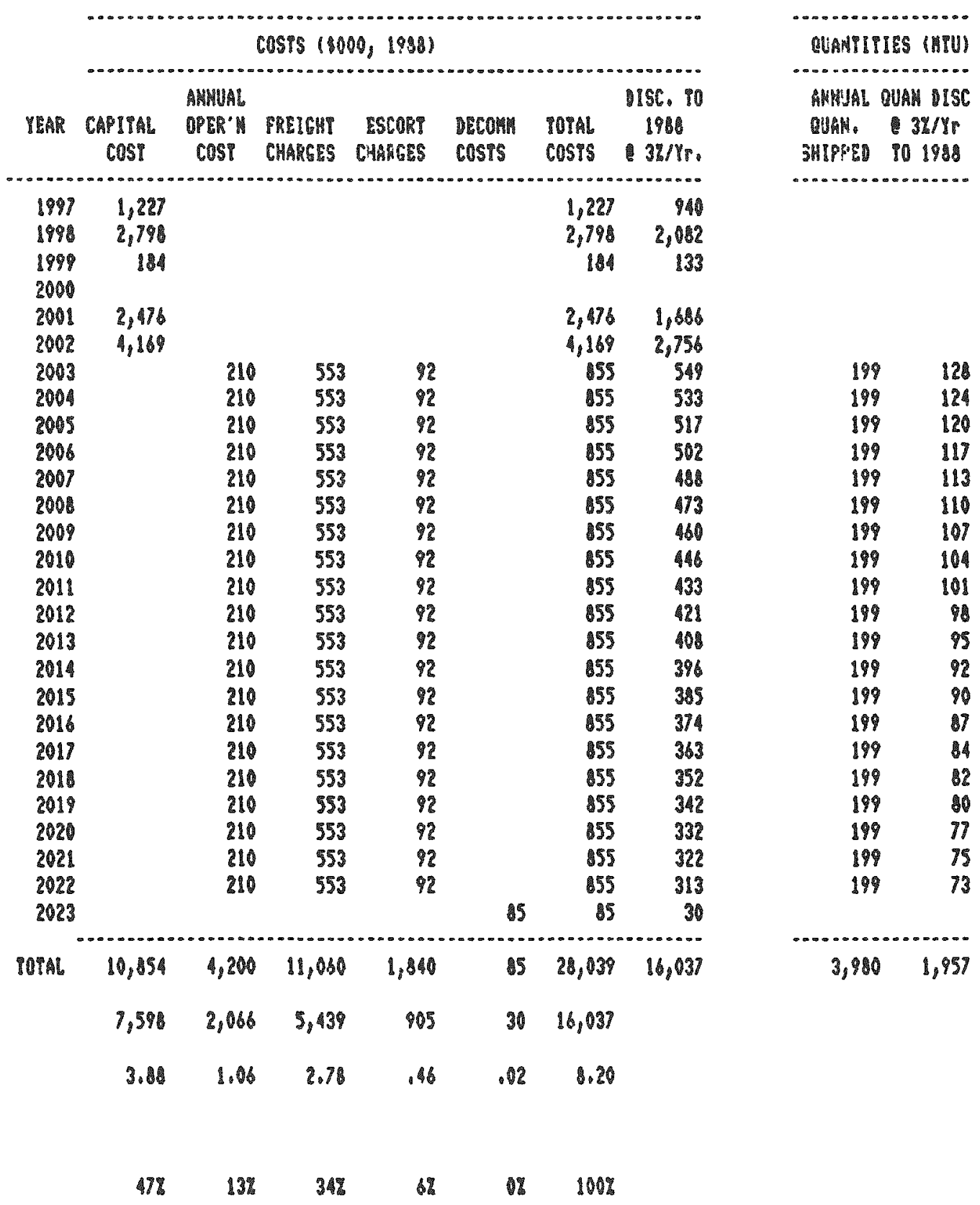


TABL

CASE - - LIF CYCLE COST OF TRAMSPORT OP PUR ACSEMLIES PROH REACPORS PO DOE PACILITIES

2800 MILES AMAY IH 23 PUP ASSEHBLY MESC SHIPPING CAS

(ONE MESC CASI IN FLEET)

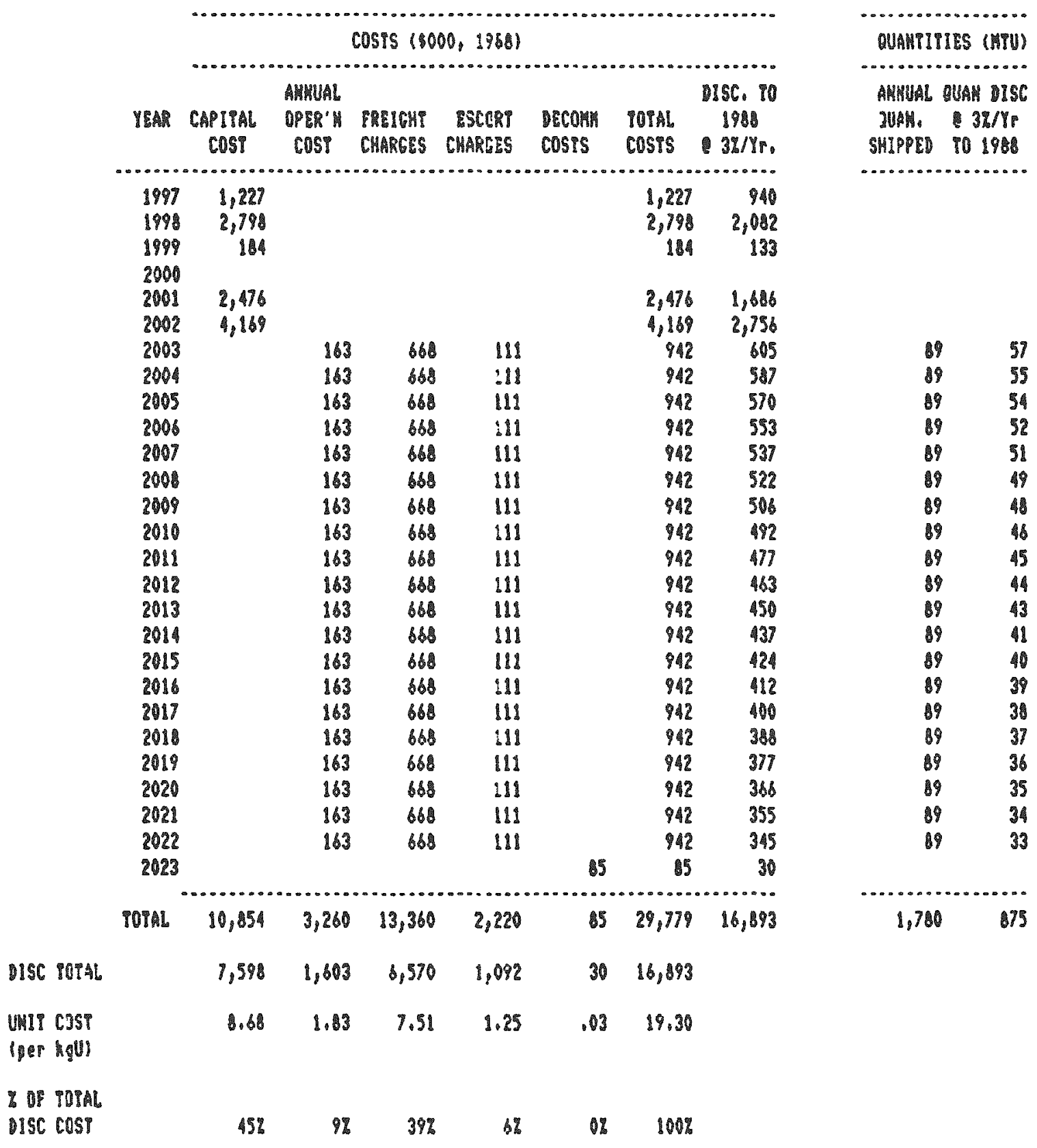


TALLE $ค-9$

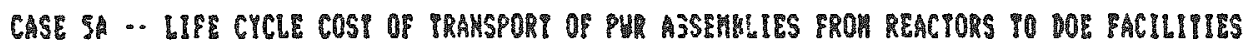

500 MILES AUAY IN 24 PUR ASSEMELY MESC SHIPPIMG CASK

(THO HESC CAIII: IV BLEET)

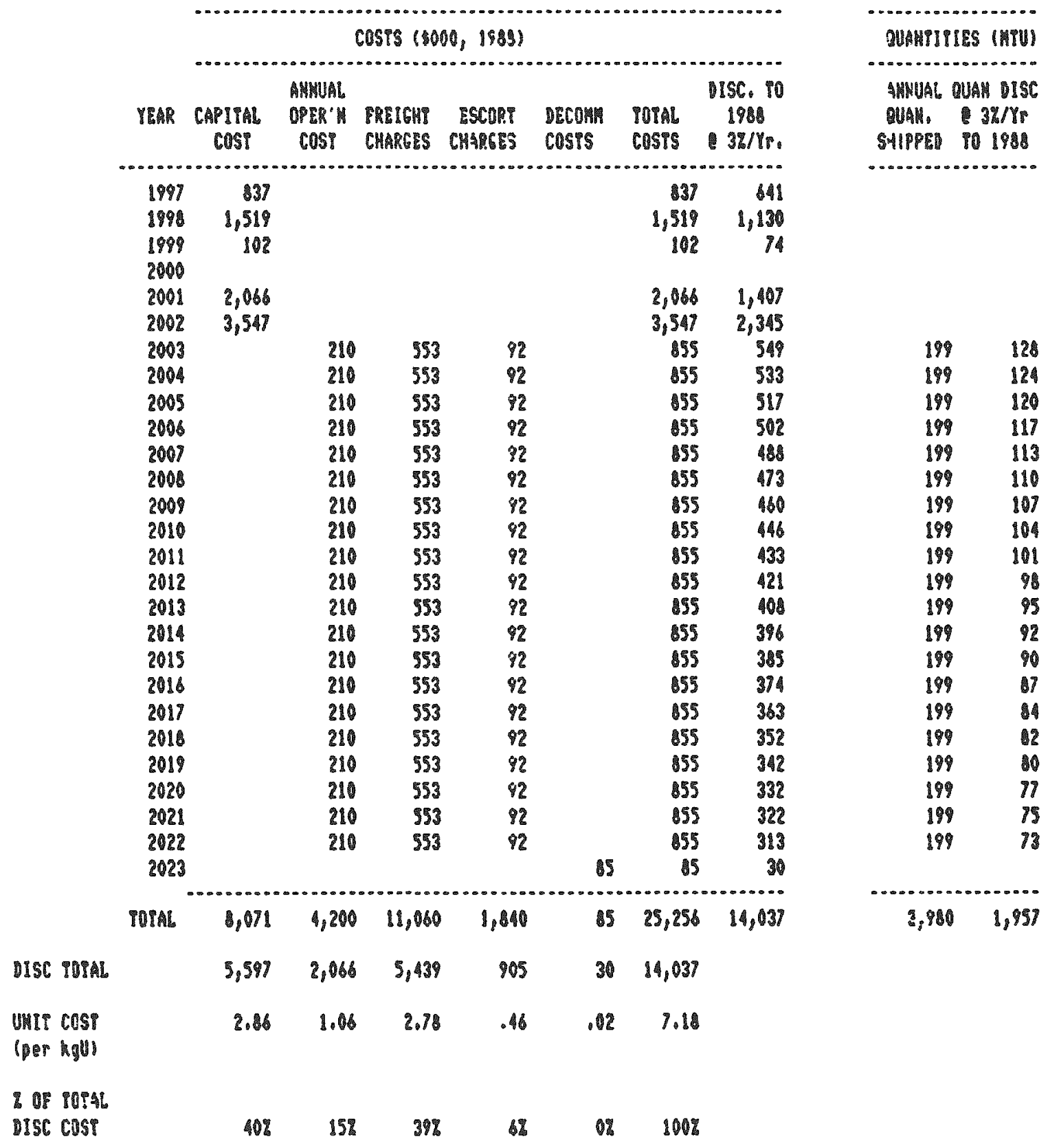


IABLS A-10

CASE 58 - LIPE CYCLE COST OR "RRAHSPOR OF PUR ASSEMRLIES FROW REACTORS PO DOE FACILITIES 2800 HILES AWAY IN A IS PUR ASSEMBLY MESC SHIPPIMG CASK ITUO MESC CASTS IN PLETP

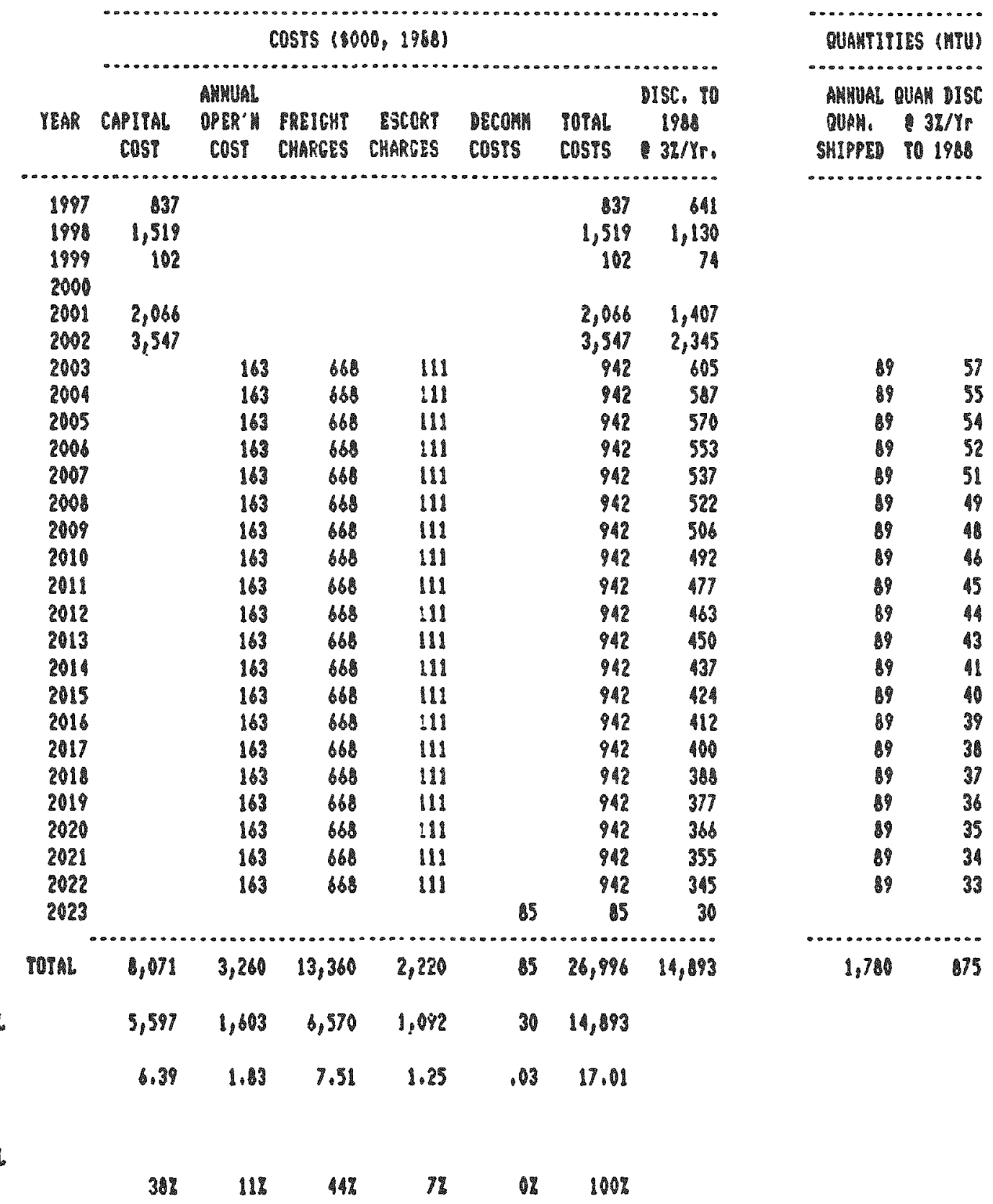


TABLER A-11

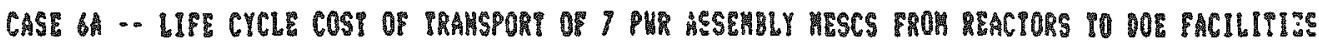
500 MILES AUAY IVI A HESC SHIPPIHG CASL

(OHE MESC CASรE :H PLEET)

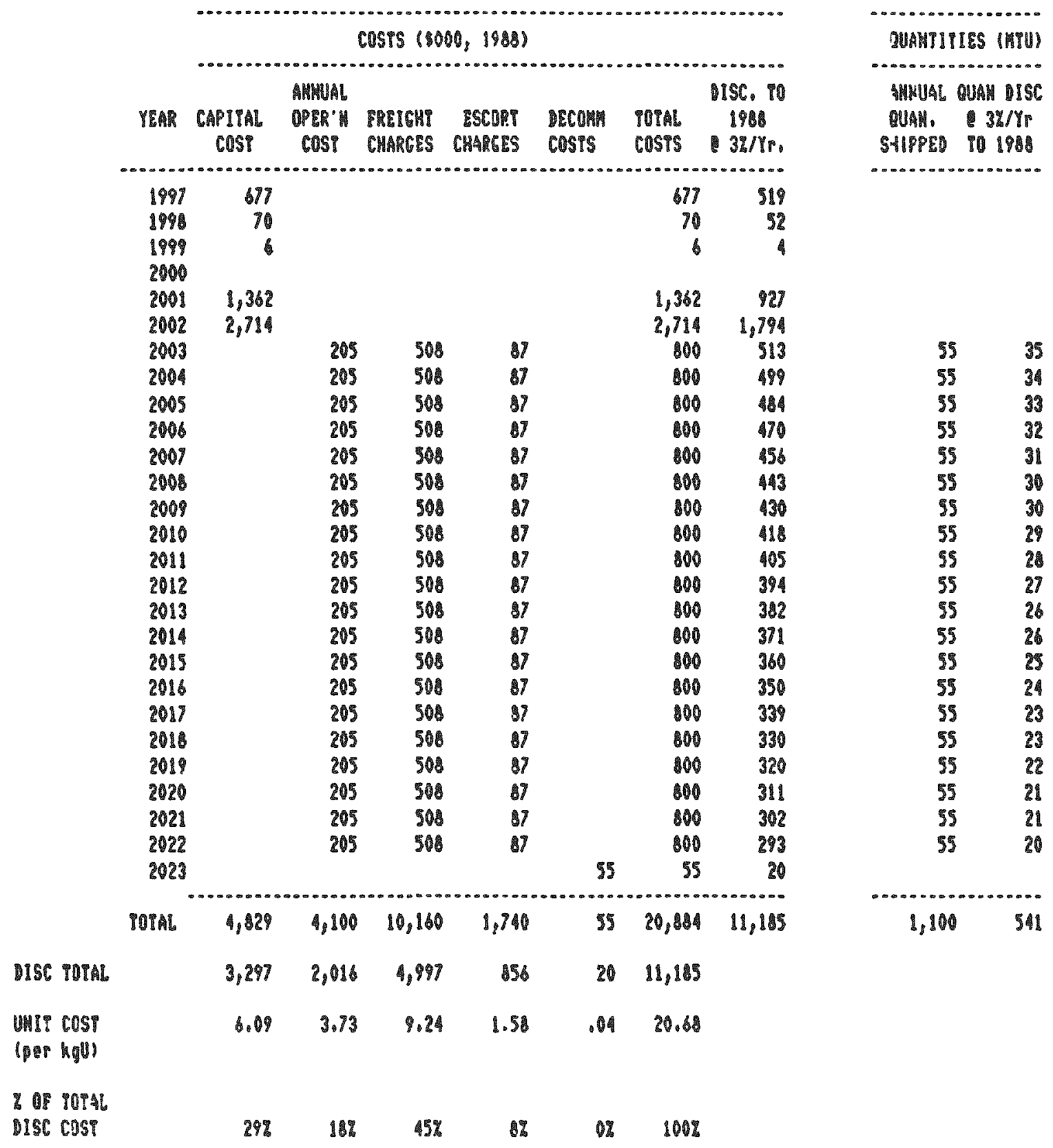


TML 12

CASE 68 - LIPE CYCLE COSI OP PRAMSPOR OF 7 PUR ASTSEMLLY HESC FROH REACTORS TO DOE FACLLIIIES 2800 HILES AUAY IN M MESC SHIPPING CAST

(OMT NESC CAST IV PLEET)

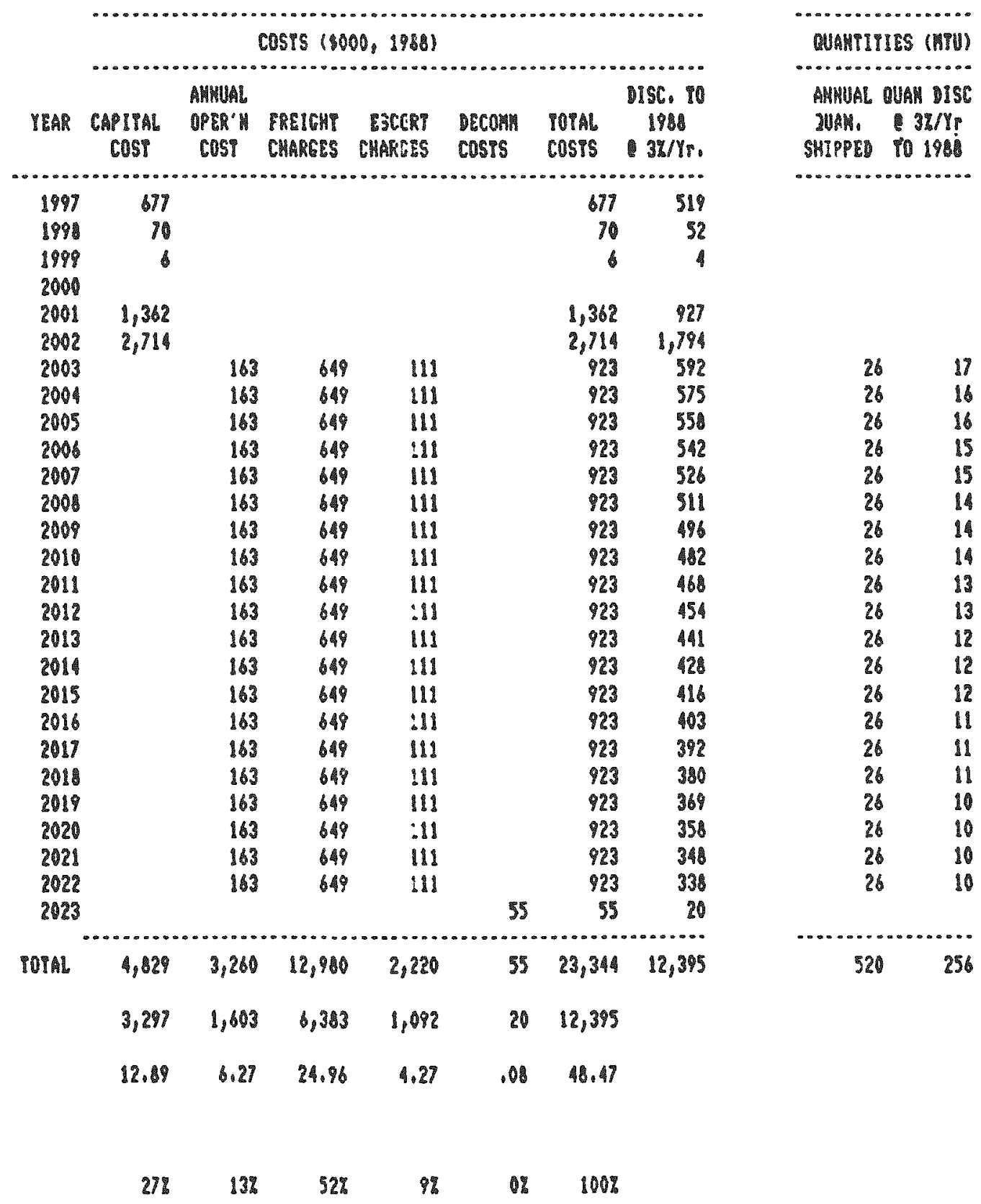

OP TOIAL DISC COST 
IABLE A-13

CASE $7 A$-. LIPE CYCLE COST OF PRAMSPORI OF 7 PU: PSSEMBLIES YROH REACTOKS TO DOE FACIUIIIES 500 MILES AHAY IN A 7 PUR ASSEMEIIY NESC SHIPPING CASL

POHE MESC CASS IM BLET)

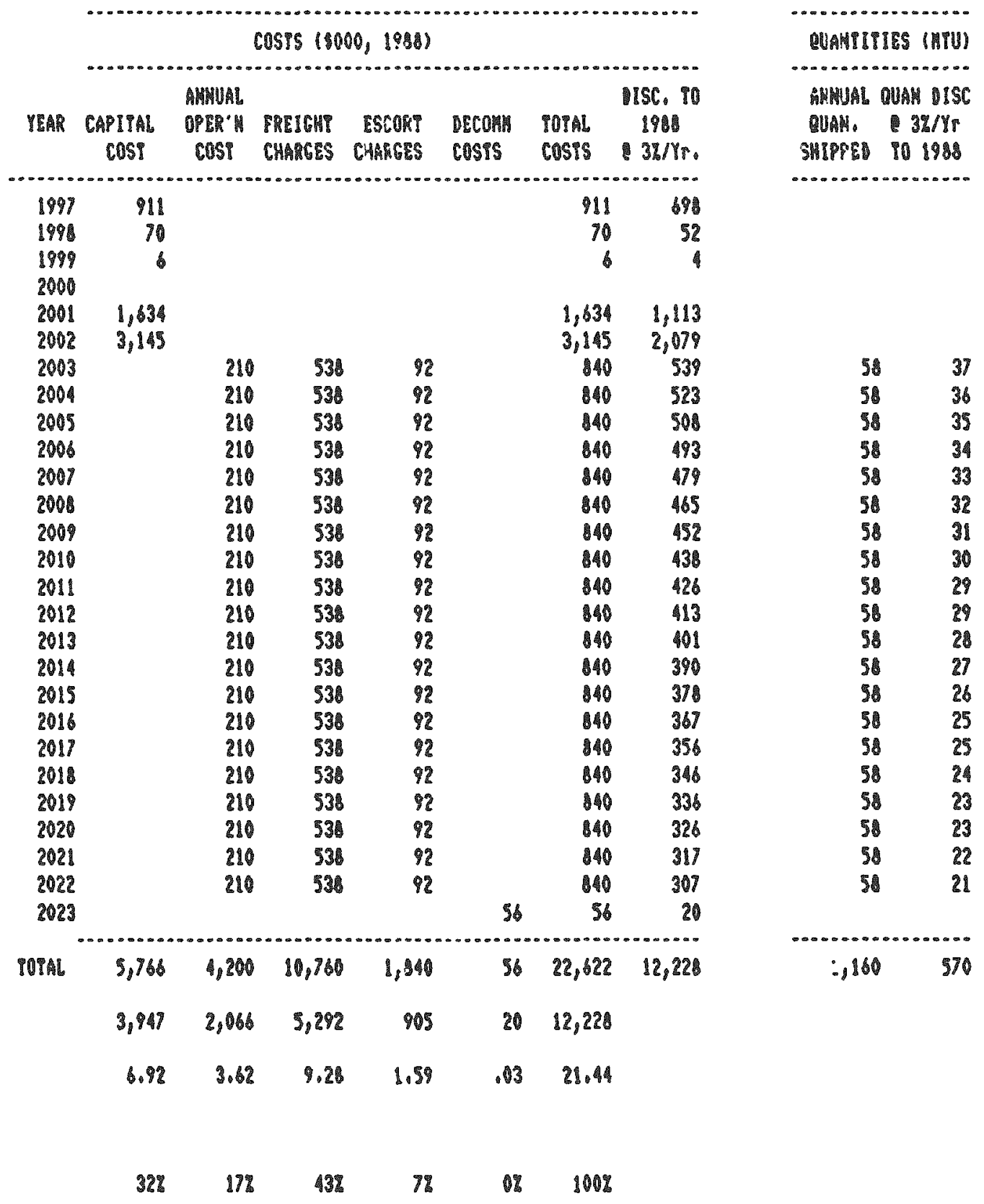


IAMES A. 14

CASE 78 -. LIFE CYCLE COSI OF TRAHSPONI OF 7 PUR ASSEHDLIES FROH REACTOKS YO DOE FACLLITIES 2800 MILES AHAY IH A ? PU ASSEMBLY MESC SHIPPIHG CASI CONE RESC CASW IN PLEET)

COSTS $(\$ 000,1986)$

QUAMIITIES (MPU)

AMUUAL QUAM DISC

QUAN. 3U/Yr

EHIPPE 101985

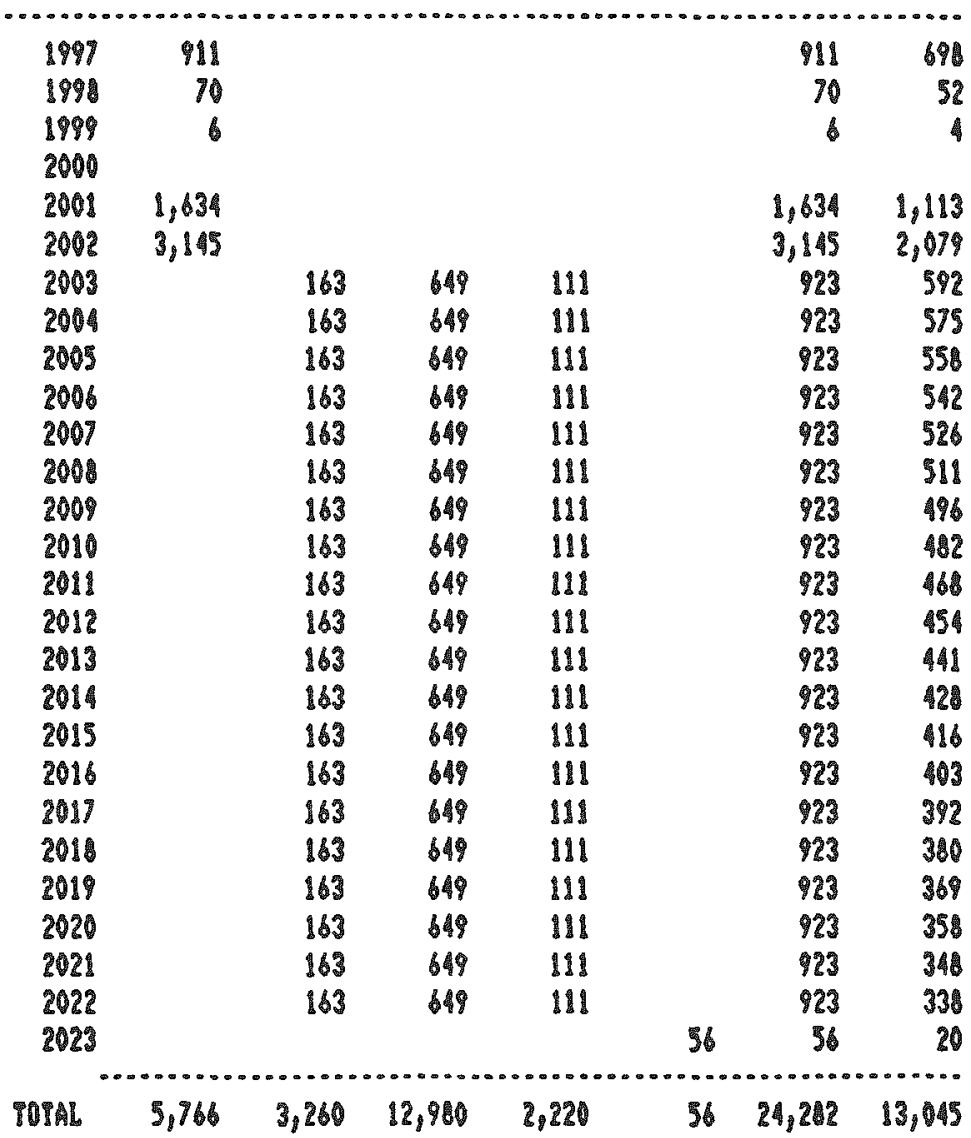

$26 \quad 17$

3616

2636

26

2615

$26 \quad 11$

$26 \quad 19$

$26 \quad 14$

$26 \quad 13$

$26 \quad 13$

$26 \quad 12$

$26 \quad 12$

$26 \quad 12$

$26 \quad 11$

2611

2611

$26 \quad 10$

$26 \quad 10$

$26 \quad 10$

$26 \quad 10$

MISC PDPAL

$3,947 \quad 1,603 \quad 6,383 \quad 1,09 \% \quad 20 \quad 13,045$

UMII COSP

[per hou\}

$\begin{array}{llllll}15.43 & 6.27 & 24.96 & 4.27 & .018 & 51.01\end{array}$

I OF TUTAL DISC COST

$30 \% \quad 12 \% \quad 49 \% \quad 2 \% \quad 0 \%$


PADIE A-15

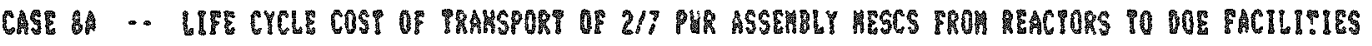

500 MILES AUAY II A 217 PUR ASSERELY MESC SHIPPING CASE (OHE MESC CASI IH MUERY

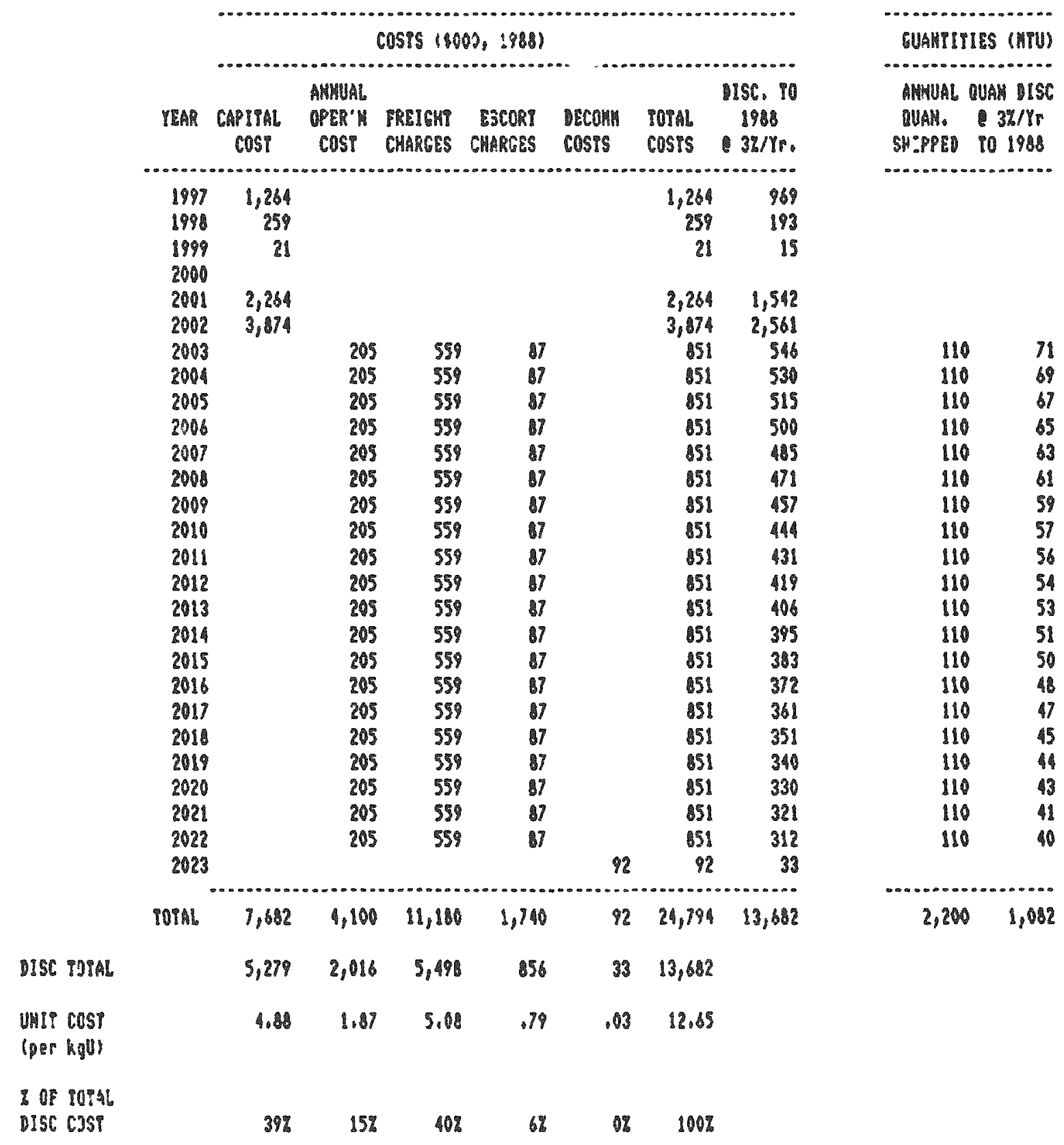


TASL $1-16$

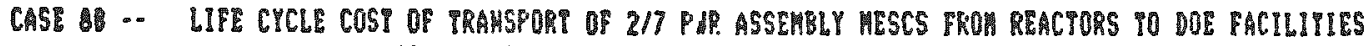

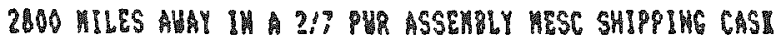
CONE MESC CASY IN FLEET)

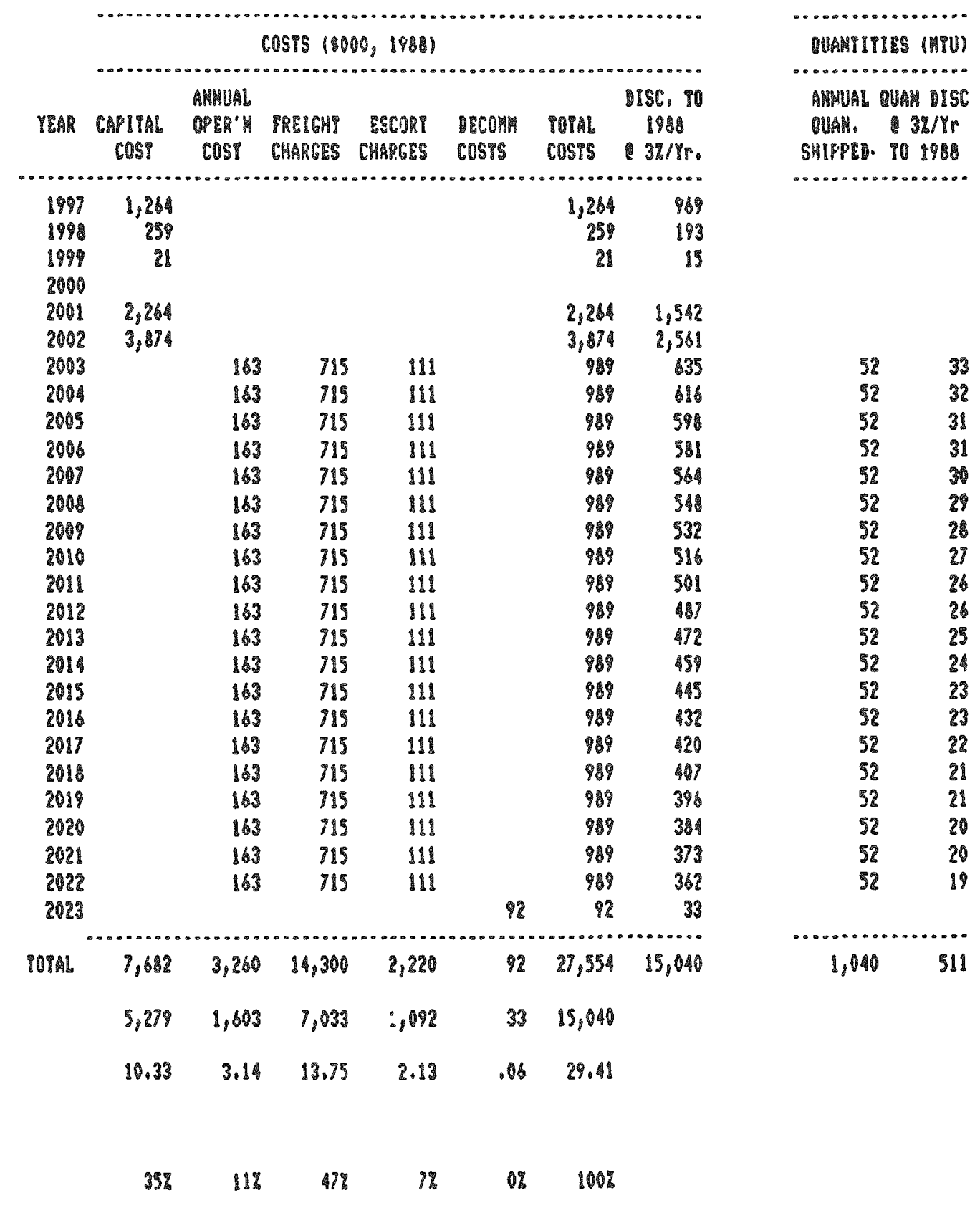


TABL $A-17$

CASE PA -. LIFE CYCLE COST OF TRAMSPORT OF 2\% PU: RSEEMBLISS FROK REACTORS TO DOE FACILIIIES

500 HILES AWAY IV A $2 / 7$ PUR ASSEMBLY HRSC SHIPPIUG CASY

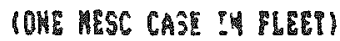

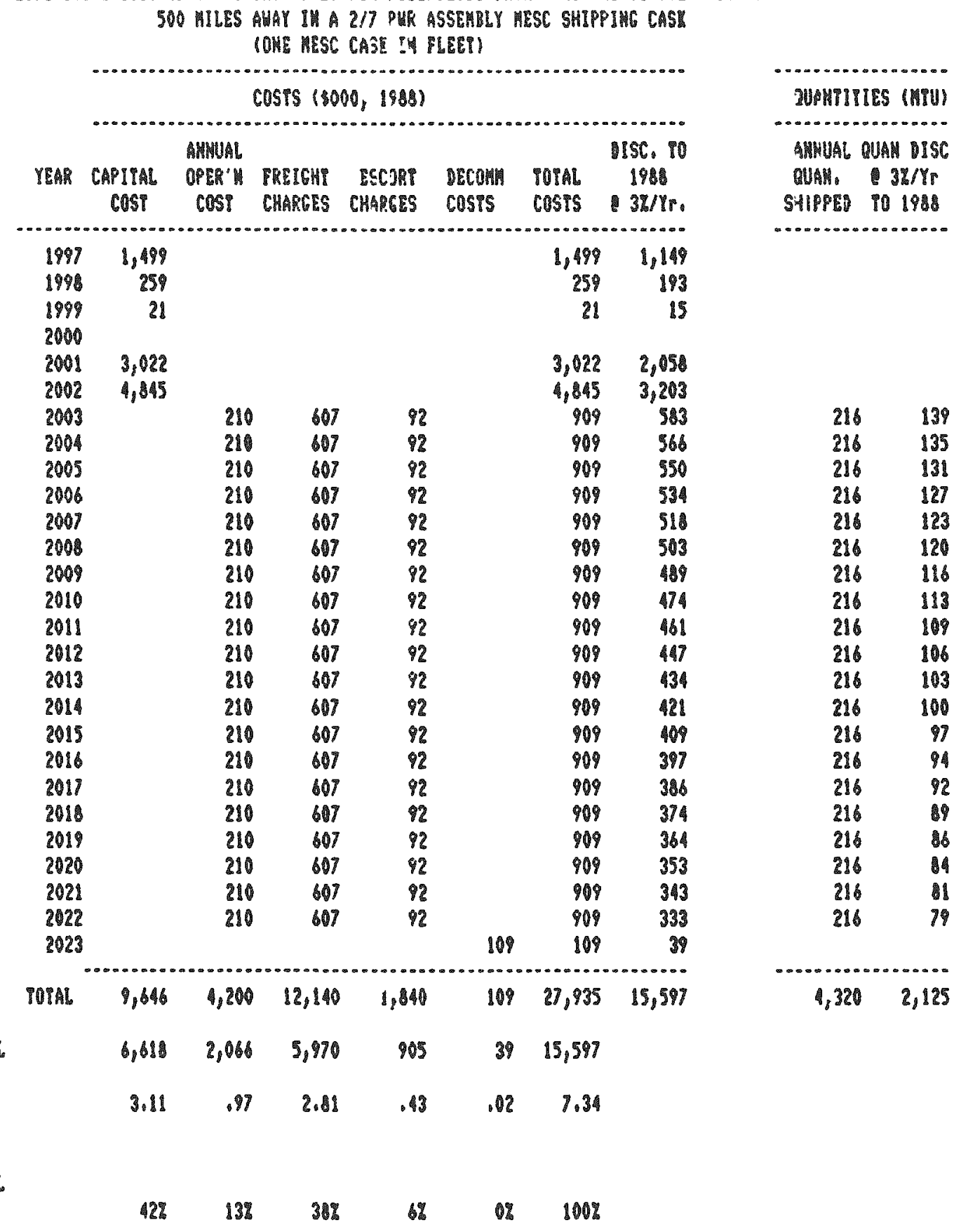

1. I0 10Pat

DISC COST 
IABLE A- 18

CASE 91 -- LIFE CYCLE COSI OF TRAMSPORI OF 26 PUR ASSEMLLIES PRON REACTORS TO DOE PACILITISS

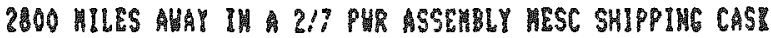
IOWE MESC CASI IN PLEET

COSTS $(1000,1985)$

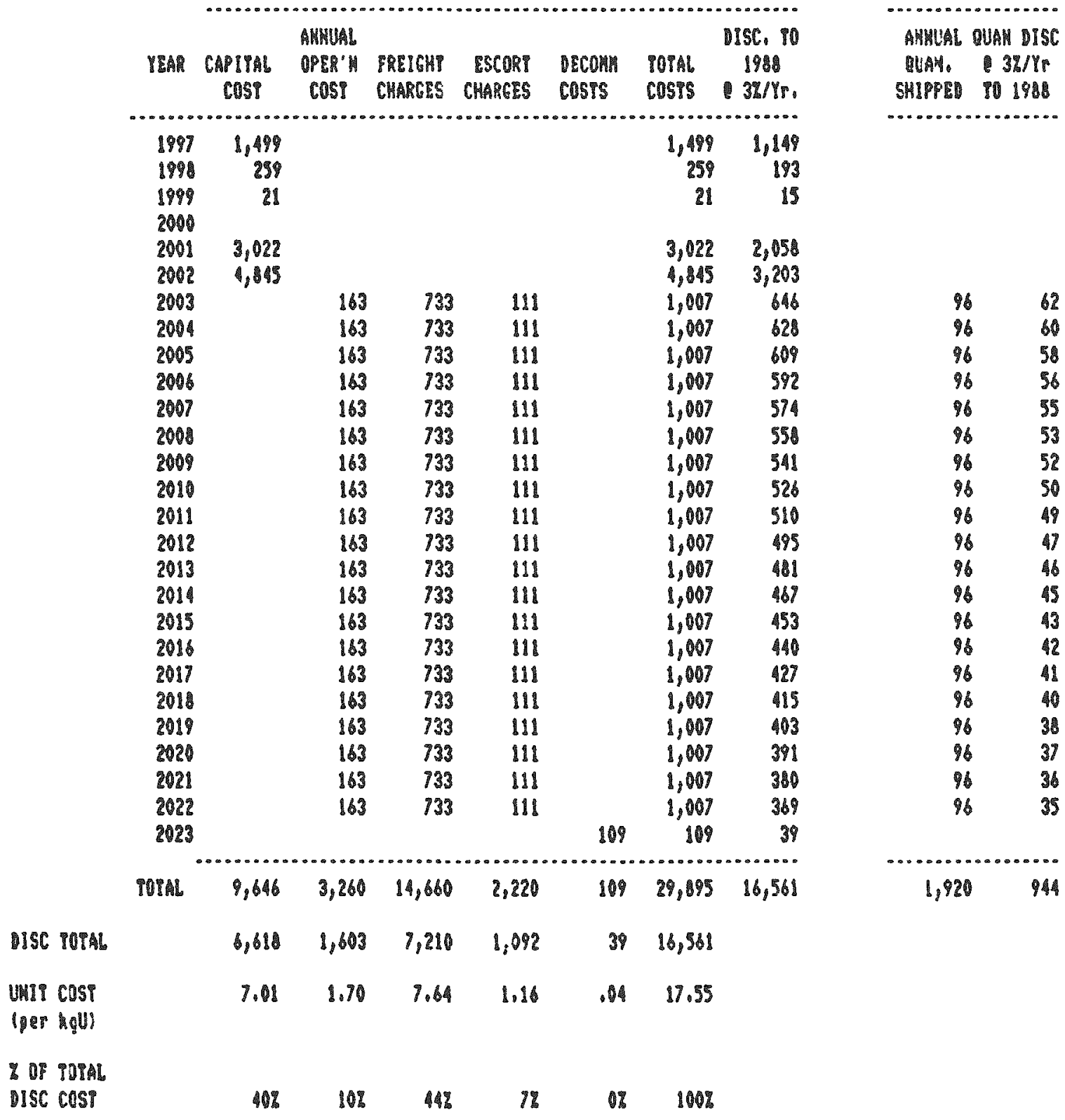

QUAMTIIISS (mT)

AWMLAL OUAM DISC

ดUAข. $3 \% / Y$ P

SHIPCD 180 


\section{APPENDIX B}

LIFE CYCLE TRANSPORT COSTS AND UNIT COST CALCULATIONS

ASSOCIATED WITH THE USE OF A SINGLE 24 PWR ASSEMBLY MESC SHIPPING CASK -- CASKS USED EITHER EXCLUSIVELY FOR SHIPMENT OF MESCS TO EXTENT AVAILABLE OR FULLY UTILIZED FOR SHIPMENT OF INDIVIDUAL FUEL ASSEMBLIES AND MESCS. 
APPENDIX B

LIFE CYCLE TRANSPORT COSTS AND UNIT COST CALCULATIONS

ASSOCIATED WITH THE USE OF A SINGLE 24 PWR ASSEMBLY

MESC SHIPPING CASK -- CASKS USED EITHER EXCLUSIVELY FOR

SHIPMENT OF MESCS TO EXTENT AVAILABLE OR FULLY UTILIZED FOR

SHIPMENT OF INDIVIDUAL FUEL ASSEMBLIES AND MESCS

The total life cycle costs associated with the use of a single 24 PWR assembly MESC shipping cask for shipment of varying quantities of spent nuclear fuel from reactors to DOE facilities were developed for instances where (i) the cask would be used to ship individual PWR assemblies to the extent there were insufficient MESCs available to fully utilize the cask capacity over its assumed 20-year lifetime, and (ii) the cask would be used to ship only MESCS and thus utilized only to the extent MESCs were available for shipment. The specific cases examined are listed below.

\begin{tabular}{|c|c|c|c|c|c|}
\hline $\begin{array}{l}\text { Case } \\
\text { No. }\end{array}$ & $\begin{array}{l}\text { Shipping } \\
\text { Distance } \\
\text { (Miles) }\end{array}$ & $\begin{array}{c}\text { Cask } \\
\text { Usage }\end{array}$ & $\begin{array}{c}\text { Total Qu } \\
\text { Shipped } \\
\text { Individual } \\
\text { PWR } \\
\text { Assemblies } \\
\end{array}$ & $\begin{array}{l}\text { ity } \\
\text { iv) }\end{array}$ & \multirow{3}{*}{$\begin{array}{c}\text { Full Utilization } \\
\text { of Cask }\end{array}$} \\
\hline $\begin{array}{l}10 \\
11 \\
12 \\
13\end{array}$ & 500 & Mixed & $\begin{array}{l}3,383 \\
2,985 \\
2,388 \\
1,990\end{array}$ & $\begin{array}{r}564 \\
940 \\
1,504 \\
1,880\end{array}$ & \\
\hline $\begin{array}{l}14 \\
15 \\
16 \\
17\end{array}$ & 2,800 & Mixed & $\begin{array}{l}3,026 \\
2,670 \\
2,136 \\
1,780\end{array}$ & $\begin{array}{r}534 \\
890 \\
1,424 \\
1,780\end{array}$ & \\
\hline $\begin{array}{l}18 \\
19 \\
20 \\
21\end{array}$ & 500 & $\begin{array}{l}\text { MESCS } \\
\text { Only }\end{array}$ & $\begin{array}{l}- \\
- \\
-\end{array}$ & $\begin{array}{r}564 \\
940 \\
1,504 \\
1,880\end{array}$ & \multirow{2}{*}{$\begin{array}{r}\text { Utilization of } \\
\text { Cask Only to } \\
\text { Extent MESCS are } \\
\text { Available for } \\
\text { Shipment }\end{array}$} \\
\hline $\begin{array}{l}22 \\
23 \\
24 \\
25\end{array}$ & 2,800 & $\begin{array}{l}\text { MESCS } \\
\text { Only }\end{array}$ & $\begin{array}{l}- \\
- \\
-\end{array}$ & $\begin{array}{r}534 \\
890 \\
1,424 \\
1,780\end{array}$ & \\
\hline
\end{tabular}


The life cycle costs and resulting unit costs for each of the foregoing cases are shown in Tables B-1 through B-16. The figures set forth in the tables were developed as follows:

(1) For Cases 10 through 17 where full utilization of the cask over its lifetime was assumed to be achieved, the total costs were assumed to be incurred over the period 1997 to 2023, inclusive. During the period 1997 through 2002 the capital cost of the cask would be incurred; during the period 2003 through 2022 the cost of operations, freight and escorts would be incurred; and in 2023 the cost of decommissioning would be incurred.

(2) For Cases 18 through 25 where the cask was used for shipment of MESCs only to the extent such were available, the total costs were assumed to be incurred commencing six years prior to the year in which shipments were initiated through 2023. During the first 6 years the capital cost of the cask would be incurred; during the years in which shipments were made the cost of operations, freight and escorts would be incurred; and in 2023 the cost of decommissioning would be incurred.

(3) With regard to the capital cost of the cask, it was assumed that the cost of design and development would be incurred in the first year, the cost of model fabrication and testing would be incurred in the second year, the NRC Certification Fee would be paid in the third year, half of the cost of cask fabrication would be incurred in the fifth year, and the other half of the cost of fabrication plus the cost of acceptance testing and auxiliary equipment would be incurred in the sixth year. It was assumed that the third and fourth year would be required by NRC to make the necessary safety reviews, and that certification would be made at the end of the fourth year.

(4) The capital cost of the casks for the various cases considered were developed as follows:

(a) For Cases 10-13 in which both shipments of individual fuel assemblies as well as MESCs were involved to achieve full utilization of the cask over its lifetime, in 500mile shipments - - the single cask (with basket) capital cost set forth in Table 4-4 was used.

(b) For Cases 14-17 in which both shipments of individual fuel assemblies as well as MESCs were involved to achieve full utilization of the cask over its lifetime, in 2,800mile shipments - - the two-cask (without basket) capital cost set forth in Table 4-4 was used. Since two casks would be used (so that the total quantities would be about the same as the 500-mile casel, the quantity 
shipped would be double that shown in the tables, each of which show the life cycle costs for a single cask.

(c) For Cases 18-21. in which shipments of MESCs only were involved and full utilization of the cask was not achieved over its lifetime, in 500-mile shipments -- the single cask (without basket) capital cost set forth in Table 4-4 was used, less the allocation for the added costs of the reference cask. Since this cask did not replace a reference cask, but rather constituted an added cask in the fleet, this allocation was not required.

(d) For Cases 22-25 in which shipments of MESCs only were involved and full utilization of the cask was not achieved over its lifetime, in 2,800-mile shipments --the two-cask (without basket) capital cost set forth in Table 4-4 was used, less the allocation for the added costs of the reference cask. Since this cask did not replace a reference cask, but rather constituted an added cask in the fleet, this allocation was not required. Moreover, since two casks would be used (so that the total quantities shipped would be about the same as the 500mile case), the quantity shipped would be double that shown in the tables, each of which show the life cycle costs for a single cask.

(5) The annual quantities shipped each year were assumed to be as follows:

\begin{tabular}{lccc} 
Form of & $\begin{array}{c}\text { MTU in } \\
\text { Single } \\
\text { Fuel Shipped }\end{array}$ & \multicolumn{2}{c}{$\begin{array}{c}\text { Annual Quantity } \\
\text { Shipped (MTU) }\end{array}$} \\
\hline MESCs & Shipment & Miles & Miles \\
Assemblies & 11.06 & $188 *$ & 89 \\
& 11.06 & 199 & 89
\end{tabular}

a Based on 13 shipments/year for 500-mile shipments (17 shipments/year for those cases marked with an asterisk), and 8 shipments/year for 2800-mile shipments.

(6) The annual cost of operation, freight, escorts and decommissioning were determined as described in Section 4.1.2.3.

(7) The total costs were discounted by $3 \% /$ year to 1988 to get the total discounted costs. 
(8) The unit costs were determined by dividing the total discounted costs by the total discounted amount (MTU) of spent fuel shipped, as follows:

Discounted Costs $=$ Discounted (Unit Costs $\times$ MTU Shipped)

Discounted Costs $=$ Unit Costs $\times$ Discounted MTU Shipped

Unit cost $=\frac{\text { Discounted Costs }}{\text { Discounted MTU Shipped }}$

A more detailed explanation of the methodology used for the unit cost calculation is set forth in Appendix F. 


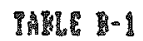

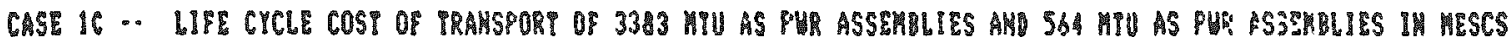

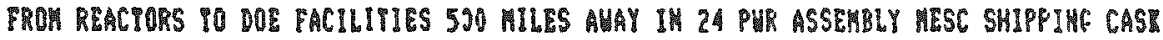
(OAE MESC CASI IN DOE FLEET)

\begin{tabular}{|c|c|c|c|c|c|c|c|c|c|c|}
\hline \multirow[b]{2}{*}{ YEARR } & \multicolumn{7}{|c|}{ cosps $(1000,1998)$} & & \multicolumn{2}{|c|}{ QUAMYITIES (ทพT) } \\
\hline & $\begin{array}{l}\text { CAPIIAL } \\
\text { COSI }\end{array}$ & $\begin{array}{l}\text { AKHUAL } \\
\text { OPER' } \\
\text { COSP }\end{array}$ & $\begin{array}{l}\text { FREICH? } \\
\text { CHARGES }\end{array}$ & $\begin{array}{l}\text { ESLORT } \\
\text { CHARGES }\end{array}$ & $\begin{array}{l}\text { DeCOAH } \\
\text { Cosis }\end{array}$ & $\begin{array}{l}\text { IUTAb } \\
\text { COSTS }\end{array}$ & $\begin{array}{l}1956, P 0 \\
1988 \\
1 \% / Y \text {. }\end{array}$ & & $\begin{array}{l}\text { AKMUAL } \\
\text { OUAY. } \\
\text { SHIPPTE }\end{array}$ & $\begin{array}{l}\text { QUAN IISC } \\
\text { C.3Z/Yr } \\
101988\end{array}$ \\
\hline $\begin{array}{l}1997 \\
1998 \\
1998 \\
2000\end{array}$ & $\begin{array}{r}1,227 \\
2,791 \\
184\end{array}$ & & & & & $\begin{array}{r}1,227 \\
2,798 \\
184\end{array}$ & $\begin{array}{r}940 \\
2,012 \\
133\end{array}$ & & & \\
\hline 2001 & 2,476 & & & & & 2,476 & 1,686 & & & \\
\hline 2002 & 4,169 & & & & & 4,169 & 2,756 & & & \\
\hline 2003 & & 210 & 553 & 92 & & 855 & 548 & & 198 & 128 \\
\hline 2004 & & 210 & 533 & 92 & & 655 & 533 & & 199 & 124 \\
\hline 2005 & & 210 & 553 & 92 & & 855 & 517 & & 189 & 120 \\
\hline 2006 & & 210 & 553 & 92 & & 855 & 502 & & 189 & 117 \\
\hline 2007 & & 210 & 553 & 82 & & 855 & 486 & & 199 & 113 \\
\hline 2000 & & 210 & 553 & 92 & & 855 & 473 & & 199 & 110 \\
\hline 2009 & & 210 & 553 & 92 & & 855 & 460 & & 199 & 107 \\
\hline 2010 & & 210 & 553 & 92 & & 855 & 448 & & 199 & 104 \\
\hline 2011 & & 210 & 553 & 92 & & 655 & 433 & & 199 & 101 \\
\hline 2012 & & 210 & $55 \overline{3}$ & 92 & & 855 & 421 & & 199 & 98 \\
\hline 2013 & & 210 & 553 & 92 & & 855 & 408 & & 199 & 95 \\
\hline 2014 & & 210 & 553 & 92 & & 655 & 396 & & 189 & 92 \\
\hline 2015 & & 210 & 553 & 92 & & 855 & 385 & & 199 & 90 \\
\hline 2016 & & 210 & 553 & 92 & & 855 & 374 & & 199 & 87 \\
\hline 2017 & & 210 & 553 & 2 & & 855 & 363 & & 199 & 84 \\
\hline 2018 & & 210 & 553 & 92 & & 855 & 352 & 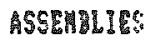 & 199 & 82 \\
\hline 2019 & & 210 & 5รక & 92 & & 855 & 342 & OHLY & 198 & 80 \\
\hline 2020 & & 205 & 552 & 8) & & 844 & 320 & Mecs & 186 & 73 \\
\hline 2021 & & 205 & 552 & 7 & & 644 & 318 & & 188 & 71 \\
\hline 2028 & & 205 & 552 & 87 & & 844 & 309 & & 195 & 69 \\
\hline 2023 & & & & & 85 & 65 & 30 & & & \\
\hline TOIAL & 10,85 & 4,1185 & 11,057 & 1,825 & 85 & 28,006 & 16,025 & & 3,947 & 1,845 \\
\hline & 7,598 & 2,060 & 5,438 & 589 & 30 & 16,025 & & & & \\
\hline & 3.91 & 1.06 & 2.80 & .46 & .02 & 8.25 & & & & \\
\hline & $47 \%$ & $13 \%$ & $34 \%$ & $6 \%$ & 02 & $100 \%$ & & & & \\
\hline
\end{tabular}


TABLE 5

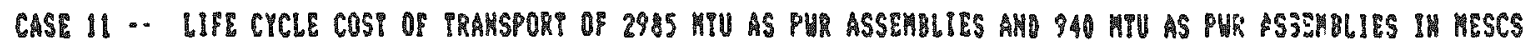
PROM REACPORS TO DOE FACILITIES 520 MILES MUAY IN 24 PUR ASSETELY MESC SHIPF: W. CASY CONE W'YSC CASI IV DOP BLETI

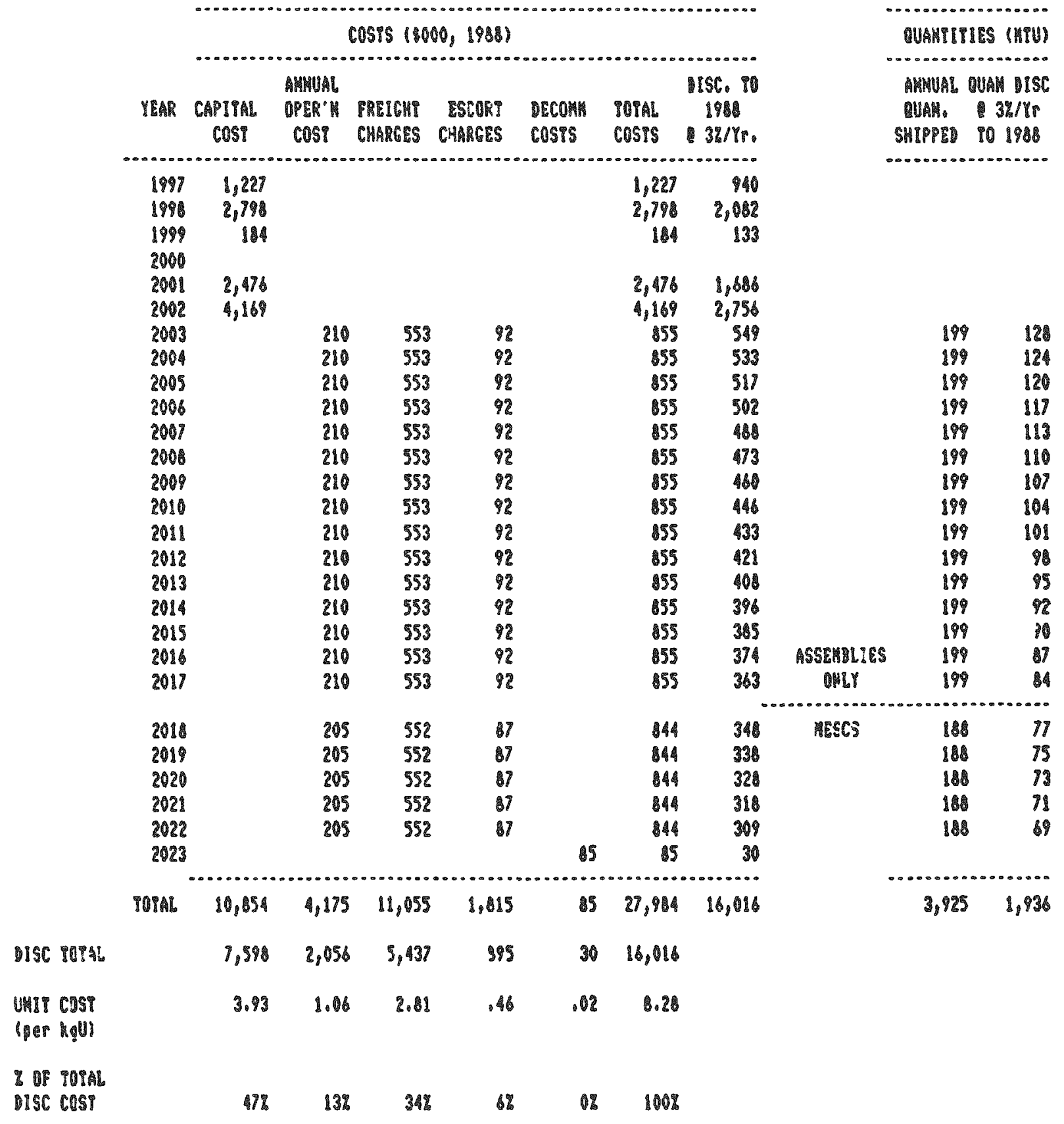


PARLE B-3

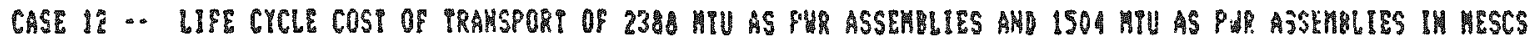
FROM REACPORS IO DOE PACULITIES 500 MULES AMAY IN 24 PUR ASSEMBLY HESC SHIPF'.IF CASK

(OHE HESC CAS IN DOE MLEET)

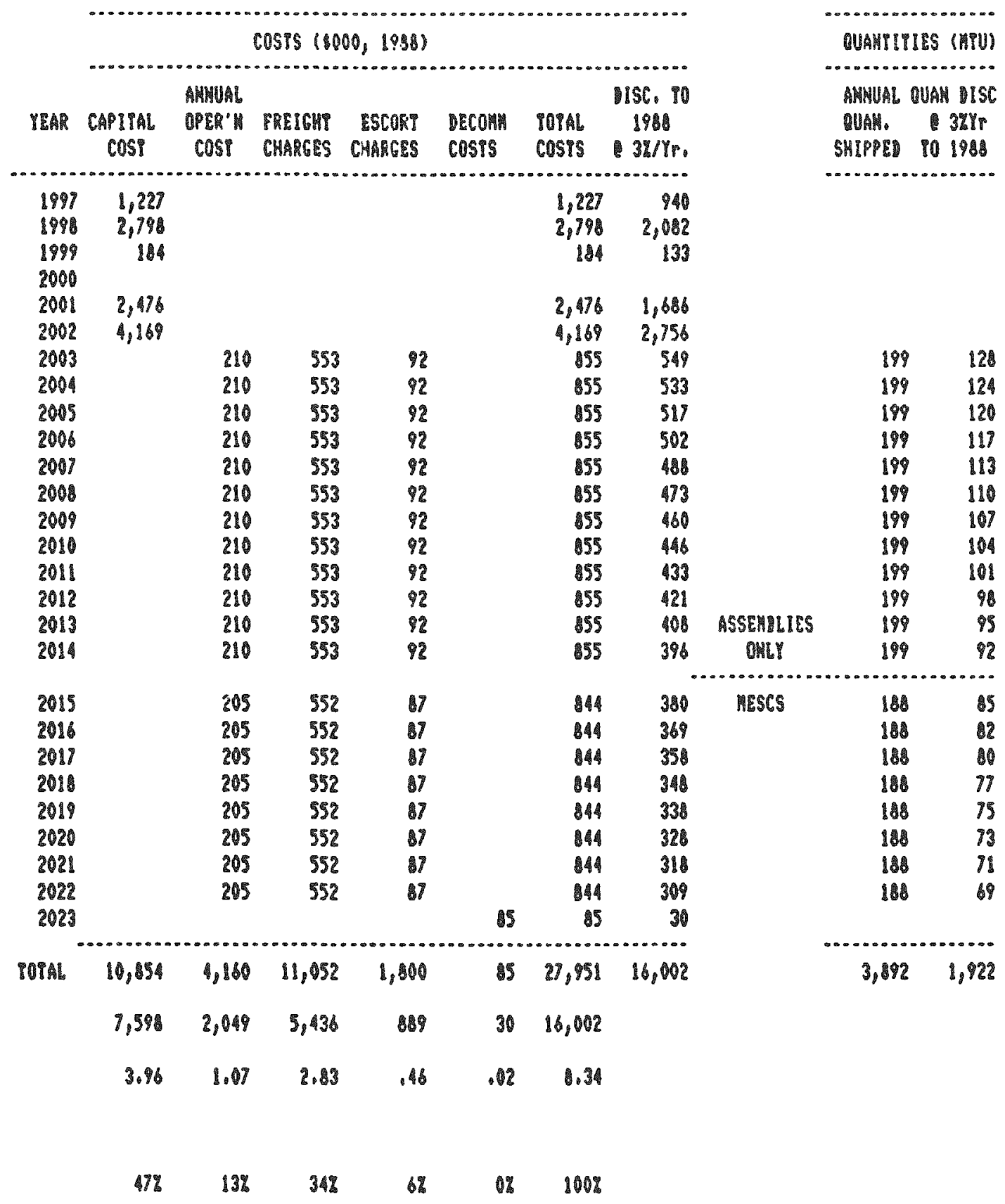


TABDB B-A

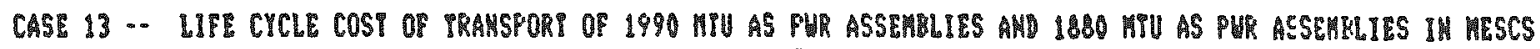
PQOH REACTORS TO DOE FACHUITIES SCO HLES AWAY IN 24 PUR ASSEUBLY MESC SHIPSIKG CASI

IONE MESC CASI IN DOE TLEET)

\begin{tabular}{|c|c|c|c|c|c|c|c|c|c|c|}
\hline \multirow{4}{*}{ 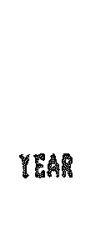 } & \multicolumn{7}{|c|}{ COSTS (1000, 1988) } & & \multicolumn{2}{|c|}{ 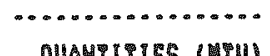 } \\
\hline & \multirow{3}{*}{$\begin{array}{c}\text { CAPIIPL } \\
\text { COST }\end{array}$} & \multirow{3}{*}{$\begin{array}{l}\text { AHNUAL } \\
\text { OPER Y } \\
\text { COSP }\end{array}$} & \multirow{3}{*}{$\begin{array}{l}\text { PREIGHT } \\
\text { CHARGES }\end{array}$} & \multirow{3}{*}{$\begin{array}{l}\text { ESCORT } \\
\text { CHARGES }\end{array}$} & \multirow{3}{*}{$\begin{array}{l}\text { EcoHh } \\
\text { Cosps }\end{array}$} & \multirow{3}{*}{\multicolumn{2}{|c|}{$\begin{array}{l}\text { DISG, Y0 } \\
1988 \\
38 / 4 \mathrm{r} .\end{array}$}} & & \multicolumn{2}{|c|}{ MWUAL QUAN DISC } \\
\hline & & & & & & & & & ดบAพ. & $3 \% / Y r$ \\
\hline & & & & & & & & & SHIPPE & T0 1988 \\
\hline 1997 & 1,227 & & & & & 1,227 & 940 & & & \\
\hline 1998 & 2,798 & & & & & 2,798 & 2,082 & & & \\
\hline 1999 & 184 & & & & & 184 & 133 & & & \\
\hline 2800 & & & & & & & & & & \\
\hline 2001 & 2,478 & & & & & 2,476 & 1,886 & & & \\
\hline 2002 & 4,189 & & & & & 4,189 & 2,756 & & & \\
\hline 2003 & & 210 & 553 & 92 & & 855 & 549 & & 199 & 128 \\
\hline 2004 & & 210 & 553 & 92 & & 855 & 533 & & 199 & 124 \\
\hline 2005 & & 210 & 553 & 92 & & 855 & 517 & & 199 & 120 \\
\hline 2006 & & 210 & 553 & 92 & & 855 & 502 & & 199 & 117 \\
\hline 2007 & & 210 & 553 & 92 & & 855 & 488 & & 199 & 113 \\
\hline 2000 & & 210 & 553 & 92 & & 855 & 473 & & 199 & 110 \\
\hline 2009 & & 210 & 553 & 92 & & 855 & 460 & & 199 & 107 \\
\hline 2010 & & 210 & $\$ 53$ & 92 & & 855 & 446 & & 199 & 104 \\
\hline 2011 & & 210 & 553 & 92 & & 55 & 433 & ASSE政LIES & 199 & 101 \\
\hline 2012 & & 210 & 553 & 92 & & 855 & 421 & OnLY & 199 & 88 \\
\hline 2013 & & 2005 & 552 & 87 & & 844 & 403 & MEçs & 183 & 96 \\
\hline 2014 & & 205 & 552 & 87 & & 844 & 391 & & 188 & 87 \\
\hline 2015 & & 205 & 552 & 88 & & 844 & 380 & & 188 & 85 \\
\hline 2016 & & 205 & 552 & 87 & & 894 & 368 & & 188 & 82 \\
\hline 2017 & & 205 & 552 & 87 & & 844 & 358 & & 188 & 80 \\
\hline 2018 & & 205 & 552 & 87 & & 844 & 346 & & 180 & 77 \\
\hline 2018 & & 205 & 552 & 88 & & 844 & 338 & & 188 & 75 \\
\hline 2020 & & 205 & 552 & 87 & & 844 & 326 & & 186 & 73 \\
\hline 2021 & & 205 & 552 & 87 & & 844 & 316 & & 188 & 71 \\
\hline 2022 & & 205 & 552 & 87 & & 844 & 309 & & 188 & 39 \\
\hline 2023 & & & & & 85 & 85 & 30 & & & \\
\hline TOTAL & 10,154 & 4,150 & 11,050 & 1,790 & 85 & 27,929 & 19,991 & & 3,60 & 1,911 \\
\hline & 7,598 & 2,045 & 5,435 & 884 & 30 & 15,991 & & & & \\
\hline & 3.98 & 1.07 & 2.84 & .46 & .02 & 8.37 & & & & \\
\hline & $48 \%$ & $13 \%$ & 348 & 82 & 03 & 1002 & & & & \\
\hline
\end{tabular}




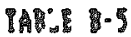

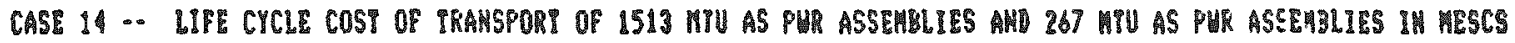

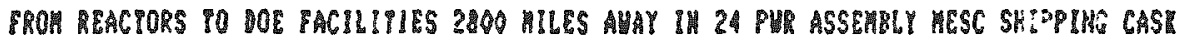

(TMO MESC CASES IN DOE PLEET)

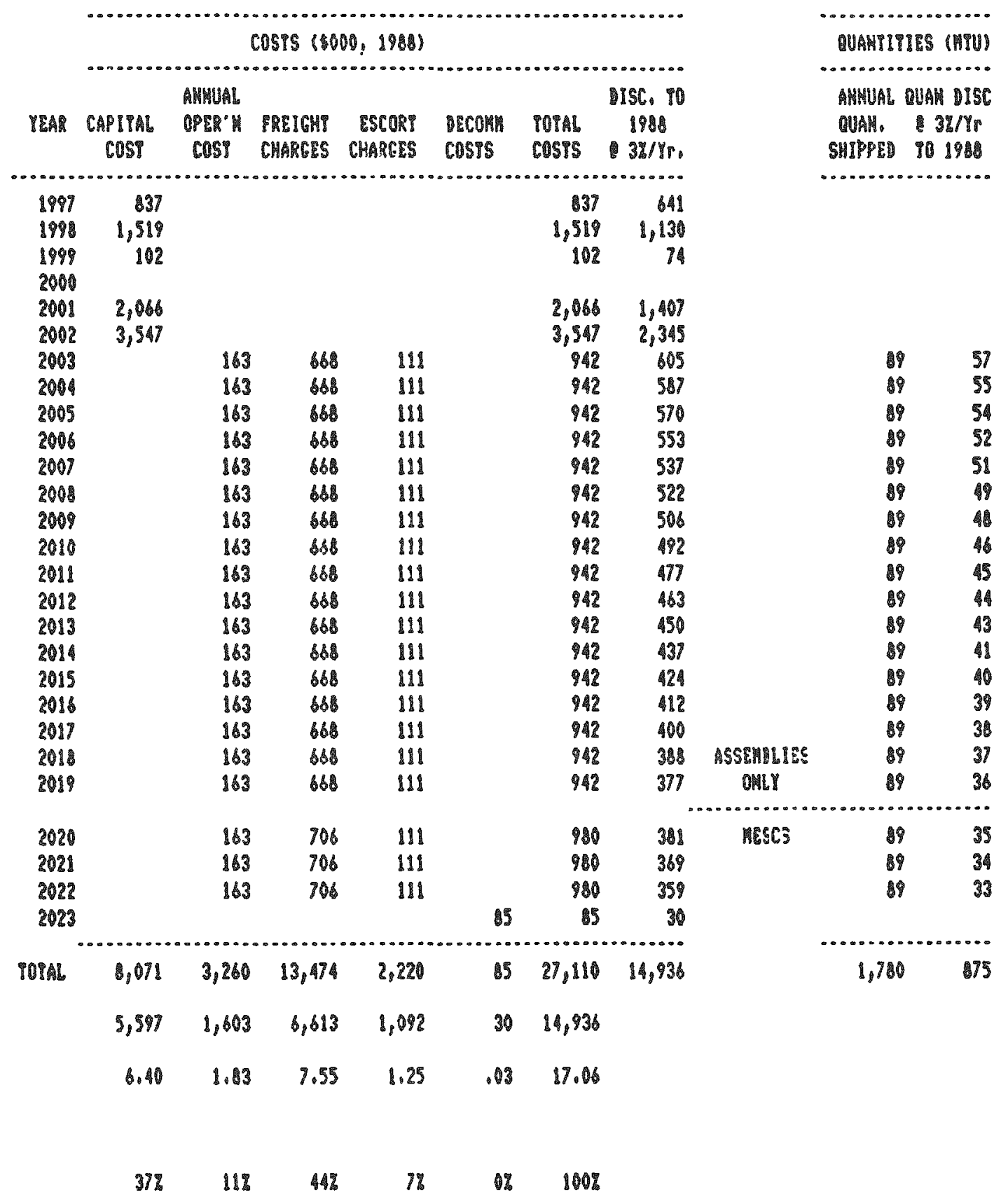


TARLE D-6

CASE 15 -. LIPE CYCLE COST OF TRAMSPORT OF 1395 MTU AS PUR ASSEMBLIES AMD 445 MPU AS PUR ASZIMULIES IU MESCS

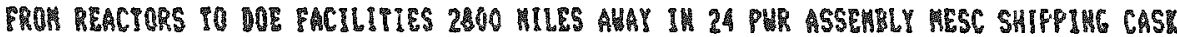

(IVO HESC CASES II DOR PLEET)

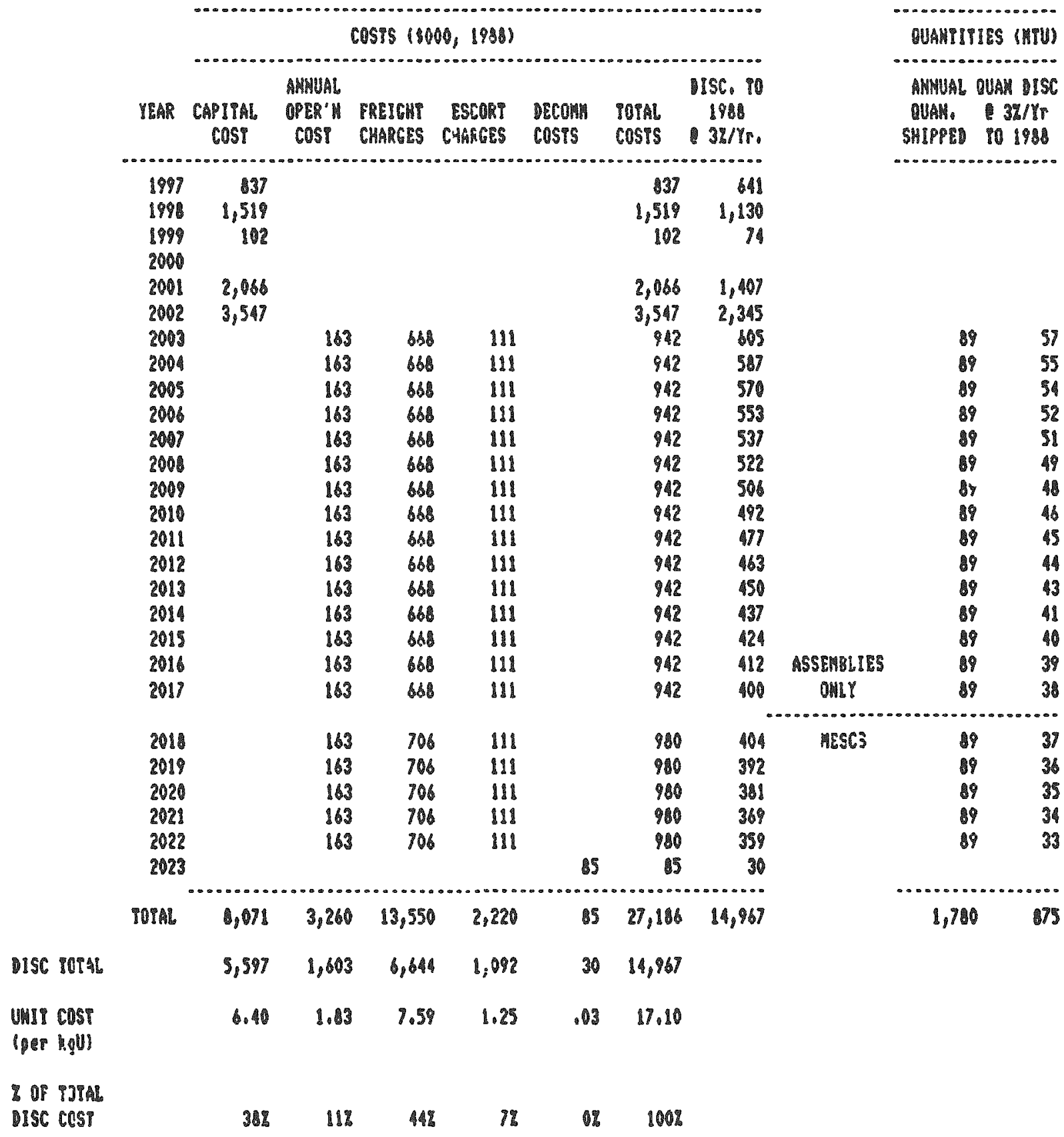


TALLE I-T

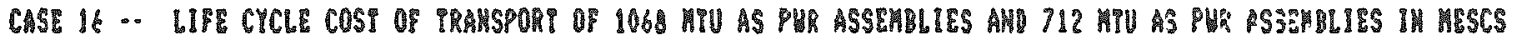

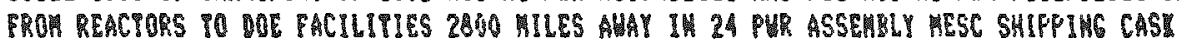

(TUO HESC CASTS IN DOE FLERT)

\begin{tabular}{|c|c|c|c|c|c|c|c|c|c|c|c|}
\hline & & $\ldots$ & C & CosTs 1800 & 90,19881 & 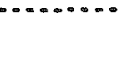 & 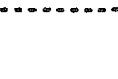 & (n) & & QUAMPITI & ISS (WTU) \\
\hline & & 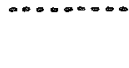 & AMMUดใ & 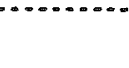 & , & ............... & 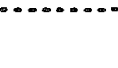 & ISC, ID & & AMHUAL & OUAK ISC \\
\hline & Y⿻𨈑㇒ & CAPIIAL & OPER'算 & PREIGN & 2SC0k9 & Secol\% & TOTAL & 1980 & & QUAY. & $32 / Y P$ \\
\hline & & $\cos 1$ & $\cos 1$ & CHAMGES & C4M̆EGES & cosTs & cosis & 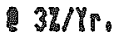 & & SHLPPED & 501988 \\
\hline & C....... & $\ldots . . . . . .$. & 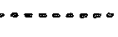 & .............. & Canomonom & 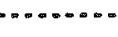 & 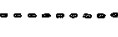 & a......... & & . & 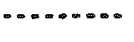 \\
\hline & 1997 & 3 & & & & & 37 & 811 & & & \\
\hline & 1996 & 1,510 & & & & & 1,519 & 1,130 & & & \\
\hline & 1990 & 102 & & & & & 102 & 74 & & & \\
\hline & 2000 & & & & & & & & & & \\
\hline & 2001 & 2,068 & & & & & 2,18 & 1,407 & & & \\
\hline & 2002 & 3,517 & & & & & 3,597 & 2,345 & & & \\
\hline & 2003 & & 163 & 86 & 111 & & 942 & 605 & & 99 & 57 \\
\hline & 2004 & & 163 & 866 & 111 & & 92 & 587 & & 89 & 58 \\
\hline & 2005 & & 183 & SBS & 111 & & 942 & 570 & & 89 & 51 \\
\hline & 2006 & & 163 & 868 & 111 & & 942 & 553 & & 89 & 52 \\
\hline & 2007 & & 13 & 868 & 111 & & 942 & 537 & & 69 & 51 \\
\hline & 2006 & & 163 & 666 & 111 & & 942 & 522 & & 89 & 19 \\
\hline & 2009 & & 143 & 56 & 111 & & 942 & 506 & & 89 & 46 \\
\hline & 2010 & & 163 & 668 & 111 & & 942 & 49 & & 8 & 46 \\
\hline & 2011 & & 183 & Sth & 111 & & 912 & 477 & & 89 & 45 \\
\hline & 2012 & & 113 & 66 & 111 & & 942 & 483 & & 89 & 4 \\
\hline & 2013 & & 183 & 860 & 111 & & 942 & 450 & ASSEMUI:E & 89 & 43 \\
\hline & 2014 & & 183 & 668 & 111 & & 942 & 437 & MLI & 98 & 41 \\
\hline & 2015 & & 163 & 706 & 111 & & 986 & 441 & MESCS & 89 & 40 \\
\hline & 2016 & & 183 & 706 & 111 & & 980 & 426 & & 69 & 39 \\
\hline & 2017 & & 163 & 706 & 111 & & 880 & 116 & & 89 & 36 \\
\hline & 2015 & & 163 & 706 & 118 & & 90 & 906 & & 89 & 37 \\
\hline & 2018 & & 163 & 706 & 111 & & 980 & 392 & & 89 & 36 \\
\hline & 2020 & & 165 & 706 & 111 & & 980 & 381 & & 89 & 35 \\
\hline & 2021 & & 163 & 706 & 111 & & 890 & 380 & & 89 & 34 \\
\hline & 2022 & & 163 & 706 & 111 & & 980 & 359 & & 9 & 33 \\
\hline & 2023 & & & & & 85 & 8 & 30 & & & \\
\hline & POPAL & 8,071 & 3,260 & 13,664 & 2,220 & 55 & 27,300 & 15,016 & & 1,780 & 875 \\
\hline QISC TOIAL & & 5,597 & 1,643 & 6,691 & 1,092 & 30 & 15,116 & & & & \\
\hline UnI COST & & $\$ .40$ & 1.3 & 7.55 & 1.25 & .03 & 17.16 & & & & \\
\hline (per houl & & & & & & & & & & & \\
\hline OE POTAL & & & & & & & & & & & \\
\hline DISC COST & & 37 & 112 & $15 \%$ & 7 & $0 \%$ & $100 \%$ & & & & \\
\hline
\end{tabular}




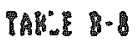

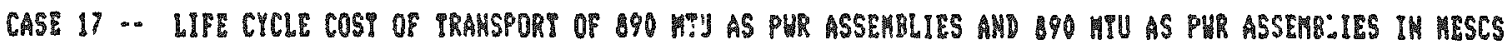

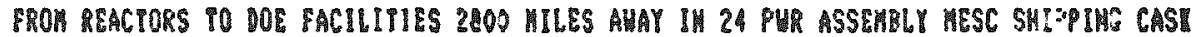
(TUO IESC CASES IN DOE PLEET)

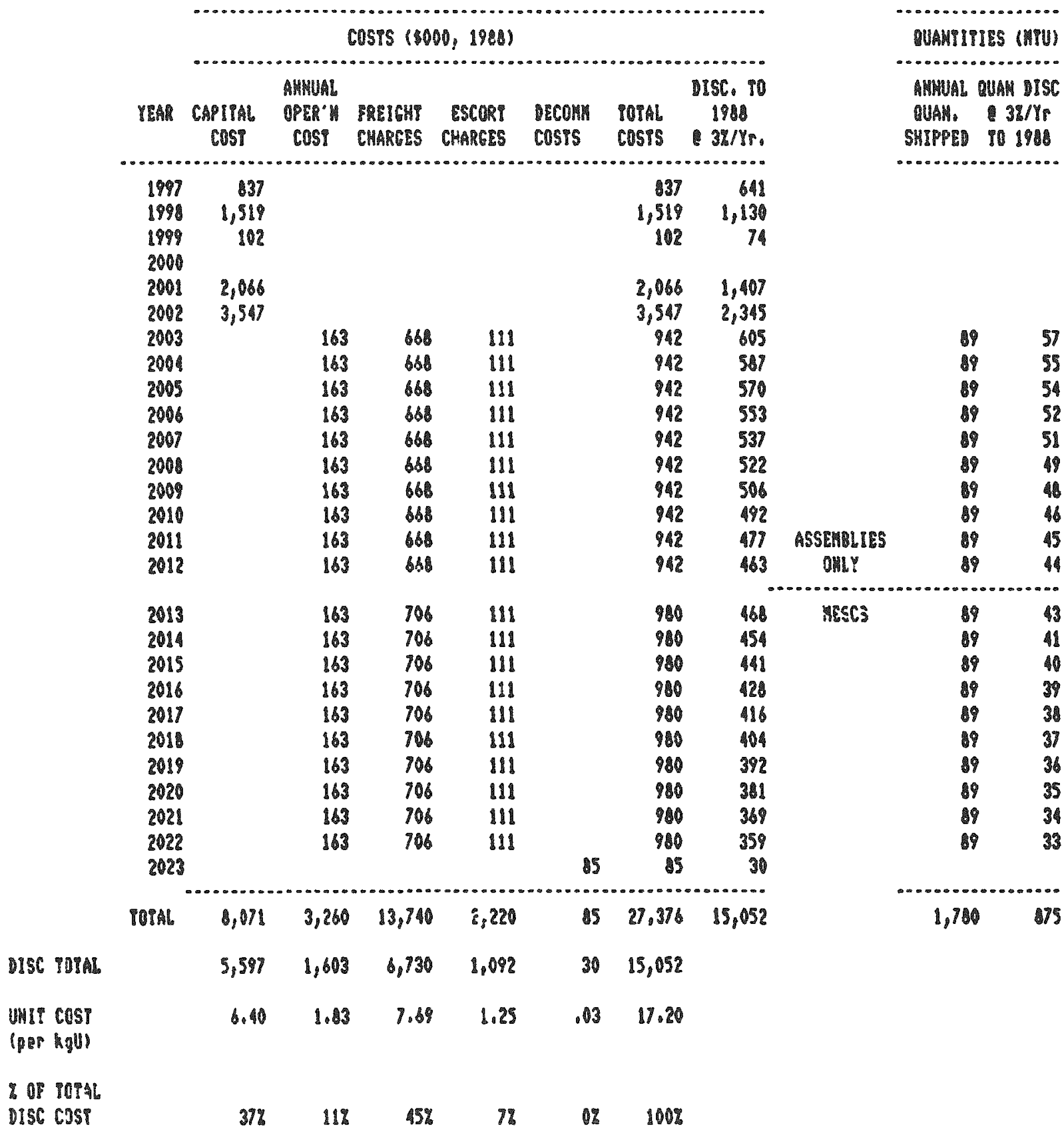


TARL:

CASE 18 .. LIFE CYCLE COST OP TRAHSPORT OF SBA MTU AS PUR ASSEMLIES IN MESCS PRON REACTORS TO JOE

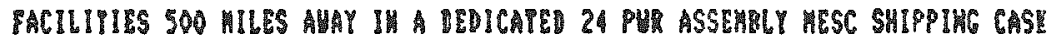
(ONE MESC CAST IH DOE PLEET)

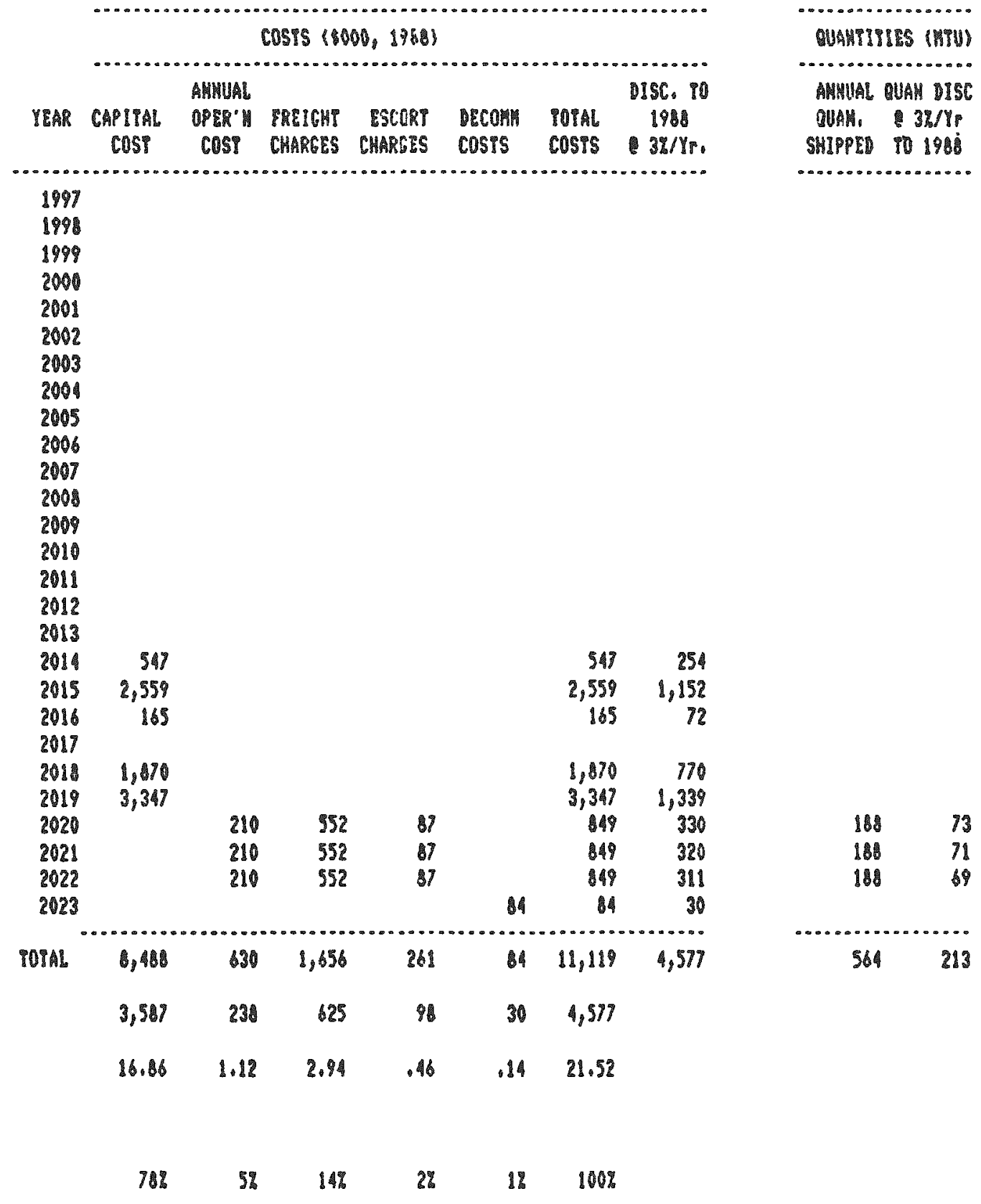


TAMLE -10

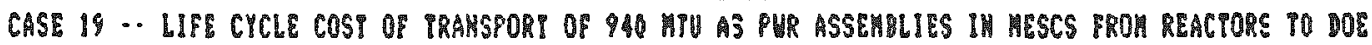
FACILIIIES 500 HILES AHAY IN DEDICATEU 24 PUR ASSENULY WLSC SHIPPIHG CAS IOWE HESC CAST IN DOE PLETI)

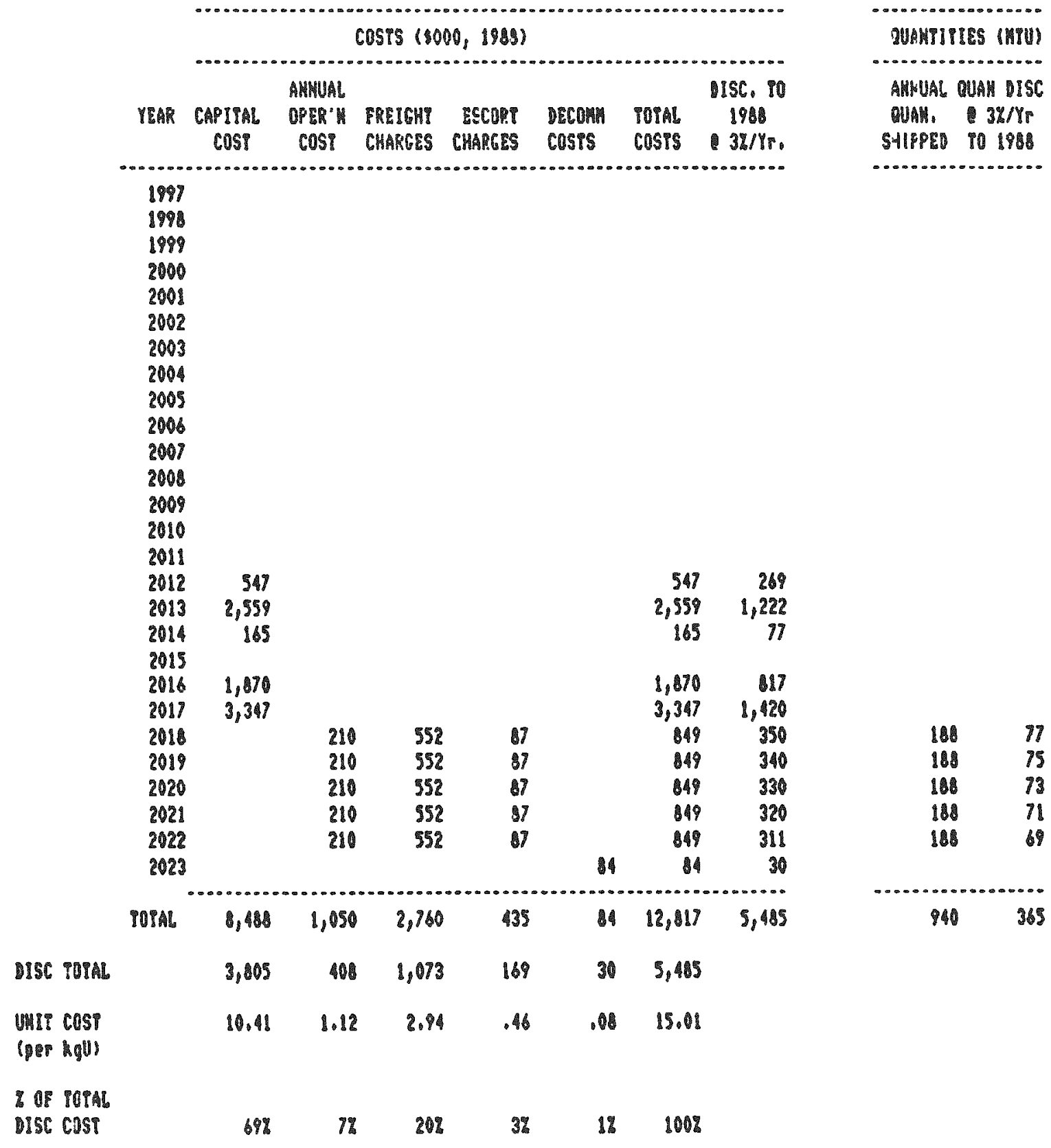


TABL: - -11

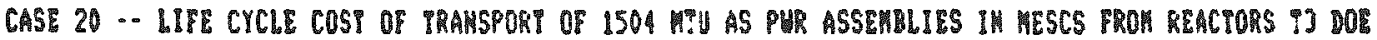

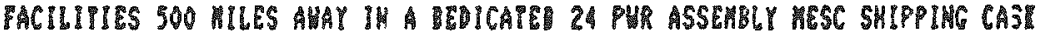
(ONE MESC CASE IV MOE PUEE?

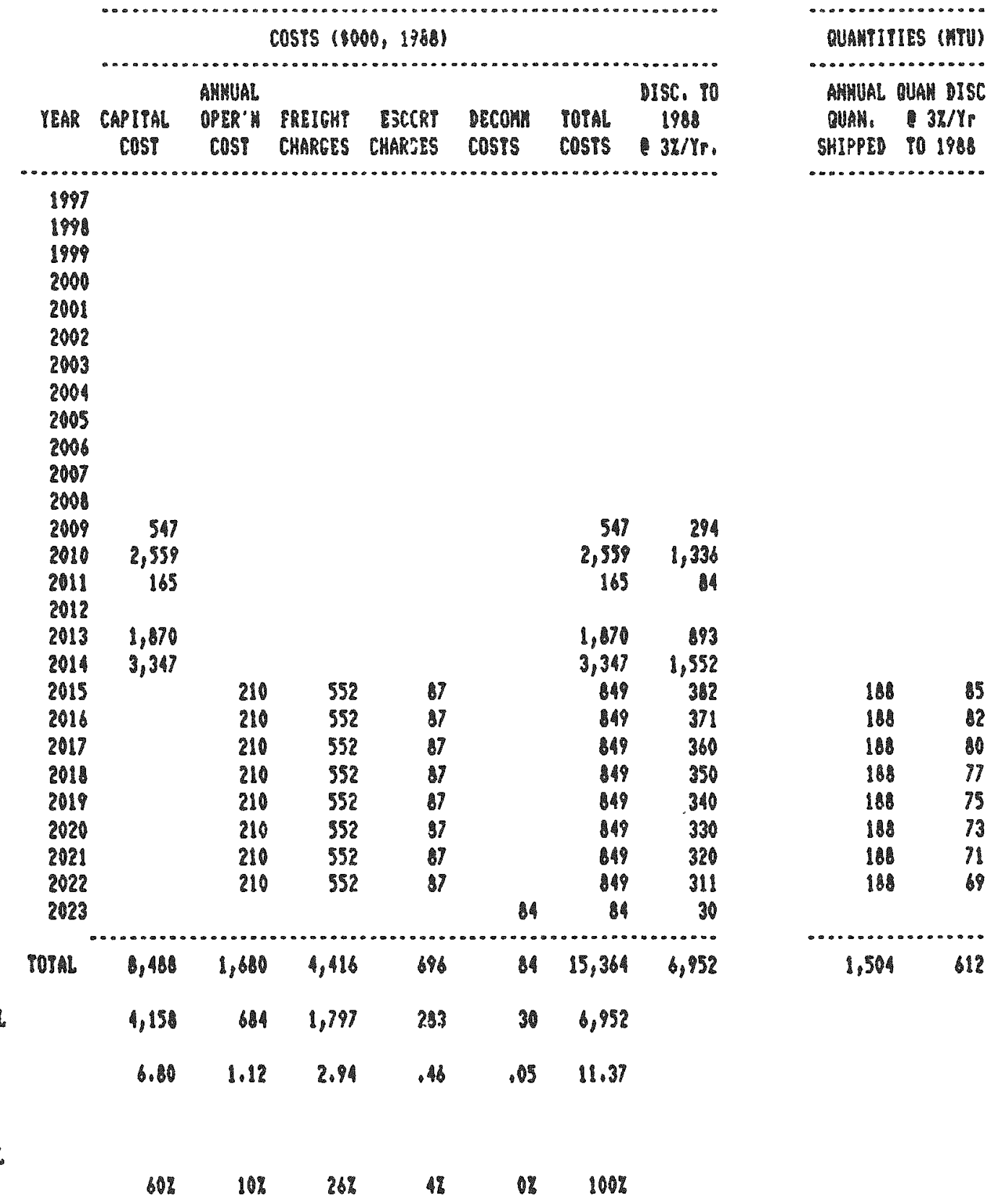


TABLE -12

CASE 21 - LIFE CYCLE COST OF PRANSPORY OR IS8O WIL AS PUR ASSEMBLISS IM HESCS FROH REACTORS IC OOE

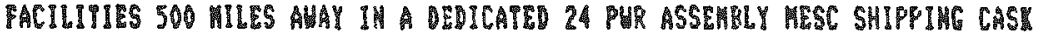
IOHE MESC CAST IN DOE FLETI)

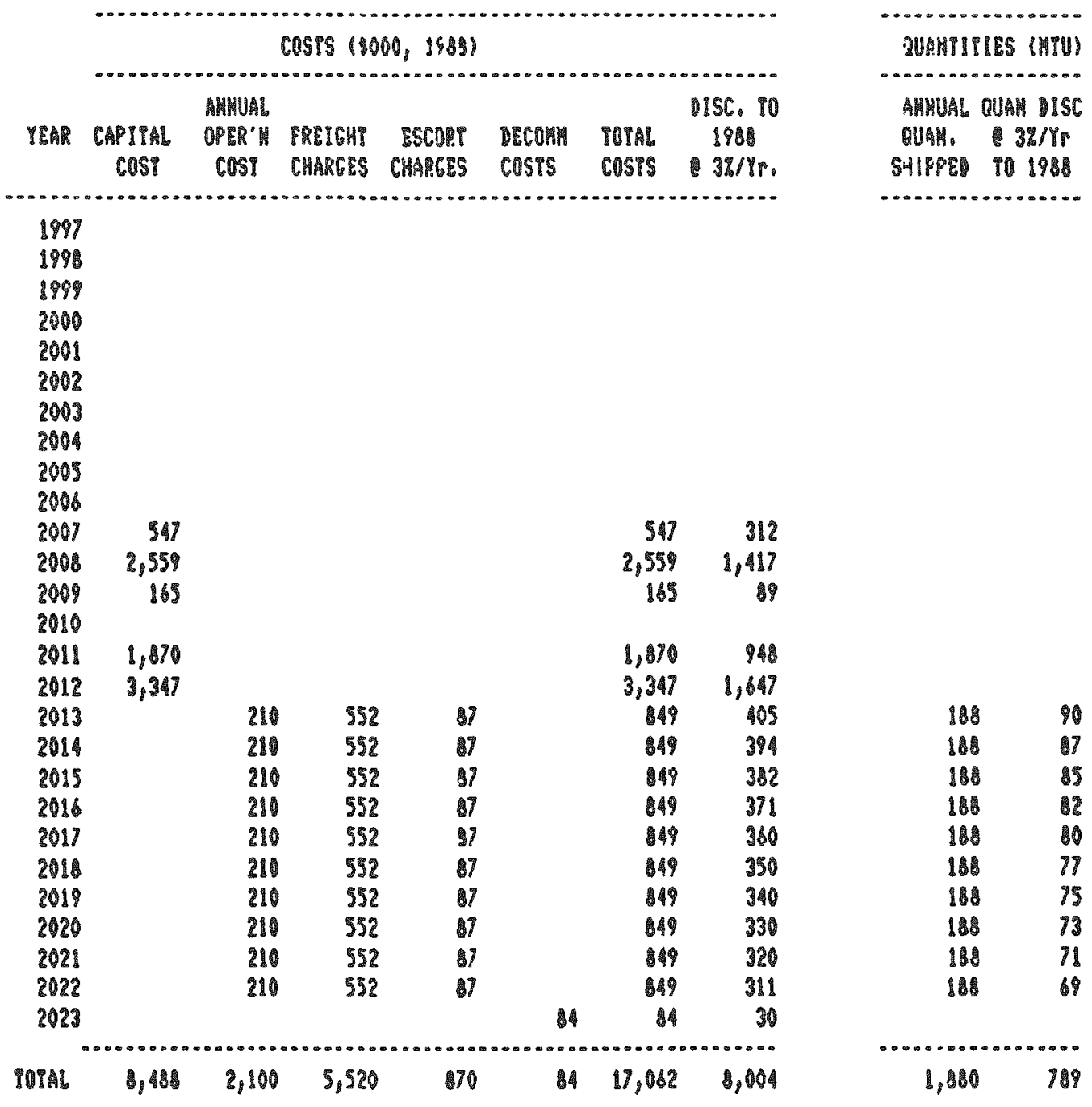

DISC TDTAL

UHIT Cos?

Pere hạu

385

308,004

5.59

$1.12 \quad 2.84$

.4

$.04 \quad 10.15$

5 Or POTAL

DISC COST

$11 \% \quad 2 \% \quad 5 \% \quad 0 \% \quad 100 \%$


PABL: $: 13$

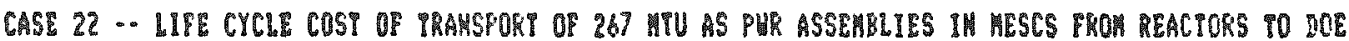

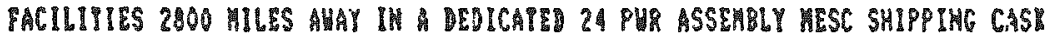
(THO MESC CASYS IU DOE FLEET)

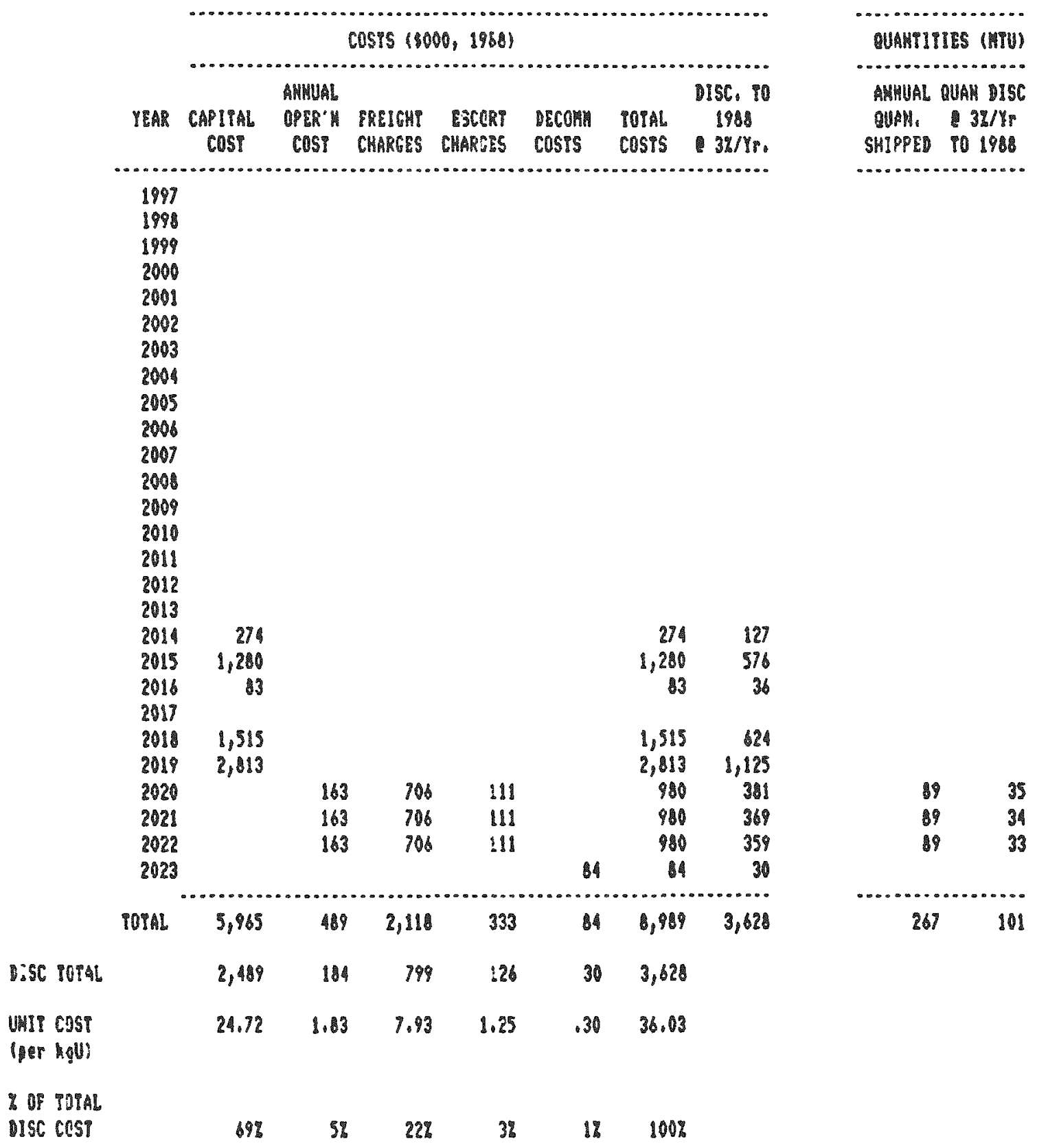


TABLE 11

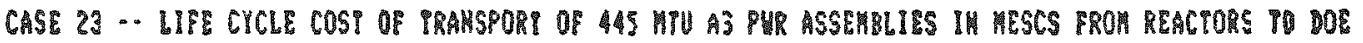
FACILIYIES 2800 HILES AHAY IK A UEDICATES 24 PUR ASSEMBLY MESC SMIPPING CAST (THO HESC CESLS IV DOE PLETI)

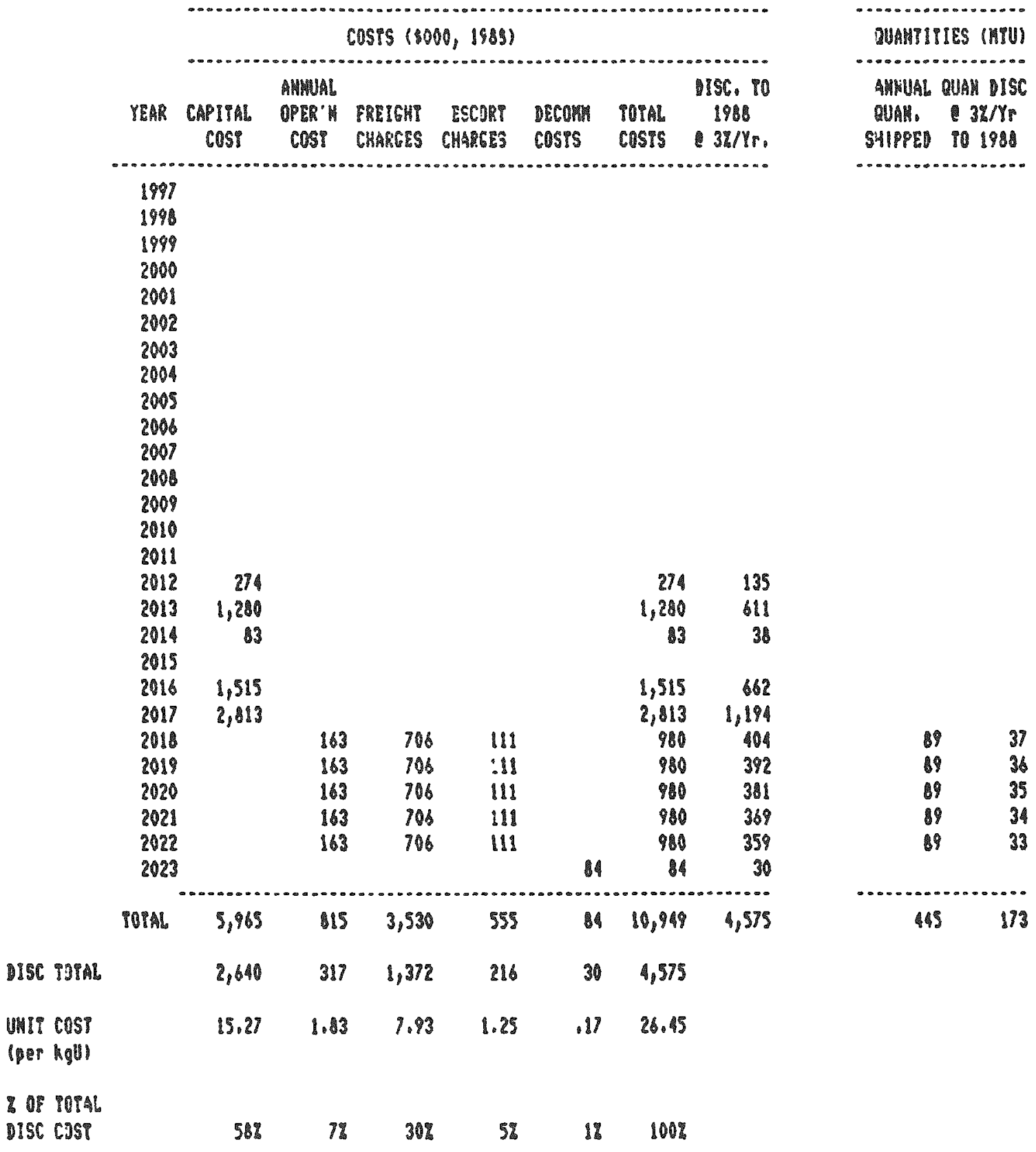


TALLE -15

CASP 24 -- LIFE CYCLE COSP OF TRAHSPORT OF 712 HTU AS PHR ASSERBLIES IH AESCS PRON REACTORS TO DOE

FACULIIIES 2800 MLES AWAY IY

(THO HESC CASYS IN DOE PLEEI)

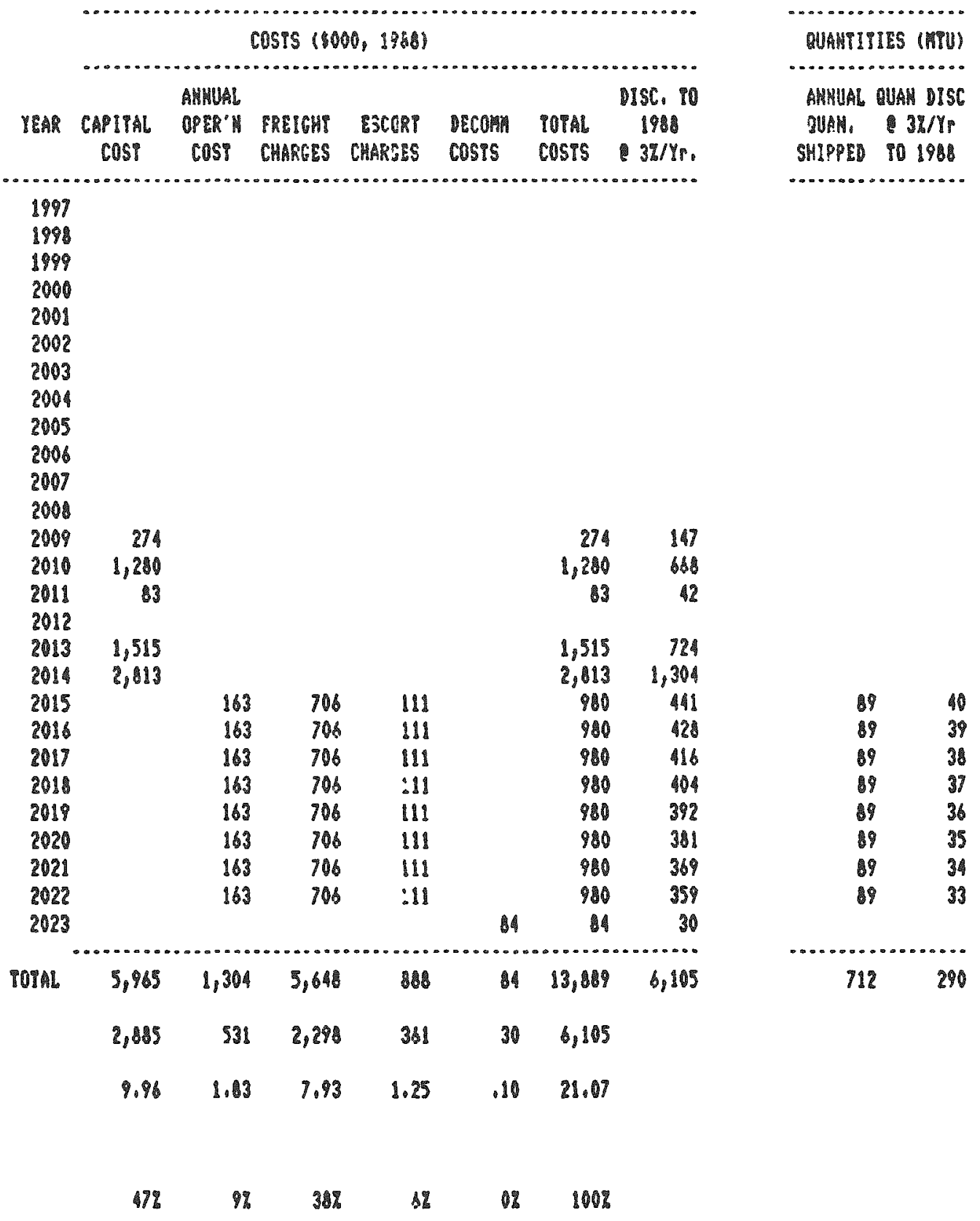


IABLE $8-16$

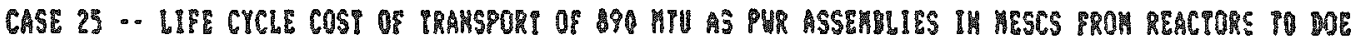
FACILITIES 2000 MILES AUAY IH A DERICATED 24 PUR ASSEKBLY HESC SHIPPIMG CASL

(TWO MESC CASIS IN DOE ELEEI)

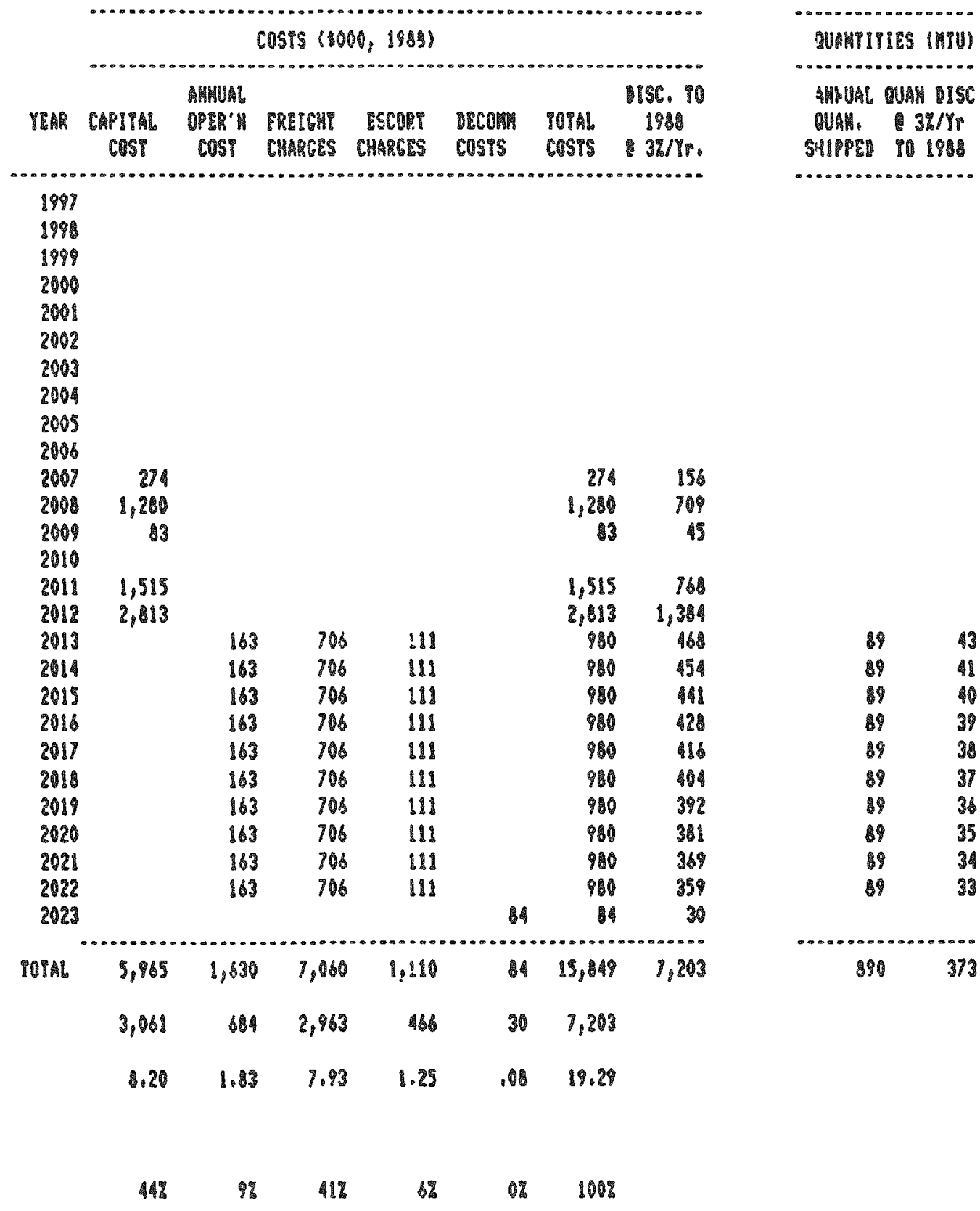


APPENDIX C

LIFE CYCLE TRANSPORT COSTS AND UNIT COST CALCULATIONS ASSOCIATED WITH THE USE OF A SINGLE 7 PWR ASSEMBLY MESC SHIPPING CASK - CASKS USED EITHER EXCLUSIVELY FOR SHIPMENT OF MESCS TO EXTENT AVAILABLE OR FULLY UTILIZED FOR SHIPMENT OF INDIVIDUAL FUEL ASSEMBLIES AND MESCS 


\author{
APPENDIX C \\ LIFE CYCLE TRANSPORT COSTS AND UNIT COST CALCULATIONS \\ ASSOCIATED WITH THE USE OF A SINGLE 7 PWR ASSEMBLY \\ MESC SHIPPING CASK - CASKS USED EITHER EXCLUSIVELY FOR \\ SHIPMENT OF MESCS TO EXTENT AVAILABLE OR FULLY UTILIZED FOR \\ SHIPMENT OF INDIVIDUAL FUEL ASSEMBLIES AND MESCS
}

The total life cycle costs associated with the use of a single 7 PWR assembly MESC shipping cask for shipment of varying quantities of spent nuclear fuel from reactors to DOE facilities were developed for instances where (i) the cask would be used to ship individual PWR assemblies to the extent there were insufficient MESCs available to fully utilize the cask capacity over its assumed 20-year lifetime, and ( $i i$ ) the cask would be used to ship only MESCs and thus utilized only to the extent MESCs were available for shipment. The specific cases examined are listed below.

\begin{tabular}{|c|c|c|c|c|c|}
\hline $\begin{array}{l}\text { Case } \\
\text { No. }\end{array}$ & $\begin{array}{l}\text { Shipping } \\
\text { Distance } \\
\text { (Miles) }\end{array}$ & $\begin{array}{l}\text { Cask } \\
\text { Usage } \\
\end{array}$ & $\begin{array}{r}\text { Total Qu } \\
\text { Shipped } \\
\text { Individual } \\
\text { PWR } \\
\text { Assemblies } \\
\end{array}$ & $\begin{array}{l}\text { ity } \\
\text { ru) } \\
\end{array}$ & \\
\hline $\begin{array}{l}26 \\
27 \\
28\end{array}$ & 500 & Mixed & $\begin{array}{r}1,045 \\
990 \\
880\end{array}$ & $\begin{array}{r}58 \\
116 \\
232\end{array}$ & \\
\hline $\begin{array}{l}29 \\
30 \\
31\end{array}$ & 2,800 & Mixed & $\begin{array}{l}468 \\
416 \\
312\end{array}$ & $\begin{array}{r}52 \\
104 \\
208\end{array}$ & $\begin{array}{c}\text { Full Utilization } \\
\text { of Cask }\end{array}$ \\
\hline $\begin{array}{l}32 \\
33 \\
34\end{array}$ & 500 & $\begin{array}{l}\text { MESCS } \\
\text { Oniy }\end{array}$ & - & $\begin{array}{r}58 \\
116 \\
232\end{array}$ & $\begin{array}{l}\text { Utilization of } \\
\text { Cask Only to }\end{array}$ \\
\hline $\begin{array}{l}35 \\
36 \\
37\end{array}$ & 2,800 & $\begin{array}{l}\text { MESCS } \\
\text { Only }\end{array}$ & - & $\begin{array}{r}52 \\
104 \\
208\end{array}$ & $\begin{array}{r}\text { Extent MESCs are } \\
\text { Available for } \\
\text { Shipment }\end{array}$ \\
\hline
\end{tabular}


The life cycle costs and resulting unit costs for each of the foregoing cases are shown in Tables $C-1$ through $C-12$. The figures set forth in the tables were developed as follows:

(1) For Cases 26 through 31 where full utilization of the cask over its 1 ifetime was assumed to be achieved, the total costs were assumed to be incurred over the period 1997 to 2023 , inclusive. During the period 1997 through 2002 the capital cost of the cask would be incurred; during the period 2003 through 2022 the cost of operations, freight and escorts would be incurred; and in 2023 the cost of decommissioning would be incurred.

(2) For Cases 32 through 37 where the cask was used for shipment of MESCs only to the extent such were available, the total costs were assumed to be incurred commencing six years prior to the year in which shipments were initiated through 2023. During the first 6 years the capital cost of the cask would be incurred; during the years in which shipments were made the cost of operations, freight and escorts would be incurred; and in 2023 the cost of decommissioning would be incurred.

(3) With regard to the capital cost of the cask, it was assumed that the cost of design and development would be incurred in the first year, the cost of model fabrication and testing would be incurred in the second year (where applicable), the NRC Certification Fee would be paid in the third year (where applicable), half of the cost of cask fabrication would be incurred in the fifth year, and the other half of the cost of fabrication plus the cost of acceptance testing and auxiliary equipment would be incurred in the sixth year. It was assumed that the third and fourth year would be required by NRC to make the necessary safety reviews, and that certification would be made at the end of the fourth year.

(4) The capital cost of the casks for the various cases considered were developed as follows:

(a) For Cases 26-31 in which both shipments of individual fuel assemblies as well as MESCs were involved to achieve full utilization of the cask over its lifetime -- the single cask (with basket) capital cost set forth in Table 4-4 was used.

(b) For Cases 32-37 in which shipments of MESCs only were involved and full utilization of the cask was not achieved over its lifetime - the single cask (without basket) capital cost set forth in Table 4-4 was used, less the allocation for the added costs of the reference cask. Since this cask did not replace a reference cask, 
but rather constituted an added cask in the fleet, this allocation was not required.

(5) The annual quantities shipped each year were assumed to be as follows:

Form of

Fuel Shipped

MESCS

Assemblies
MTU in

Single

Shipment

3.23

3.23
Annual Quantity

Shipped (MTU)

$500 \quad 2800$

Miles Miles

$55^{*} \quad 26$

58

26

a Based on 18 shipments/year for 500-mile shipments (17 shipments/year for those cases marked with an asterisk), and 8 shipments/year for 2800 -mile shipments.

(6) The annual cost of operation, freight, escorts and decommissioning were determined as described in Section 4.1.2.3.

(7) The total costs were discounted by $3 \% /$ year to 1988 to get the total discounted costs.

(8) The unit costs were determined by dividing the total discounted costs by the total discounted amount (MTU) of spent fuel shipped, as follows:

Discounted Costs $=$ Discounted (Unit Costs $\times$ MTU Shipped)

Discounted Costs $=$ Unit Costs $\times$ Discounted MTU Shipped

Unit Cost $=\frac{\text { Discounted Costs }}{\text { Discounted MTU Shipped }}$

A more detailed explanation of the methodology used for the unit cost calculation is set forth in Appendix $F$. 
TARE C-1

CASE 26 - LIFE CVCLE COSP OF IRAMSPOAT OP 1045 MUU AS PUR ASSEMLIES AM SO MIU AS PUR ASSEMLIES IN MESCS

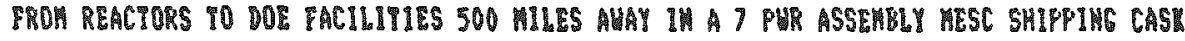

(OHE MESC CASE IV DOE REEEI)

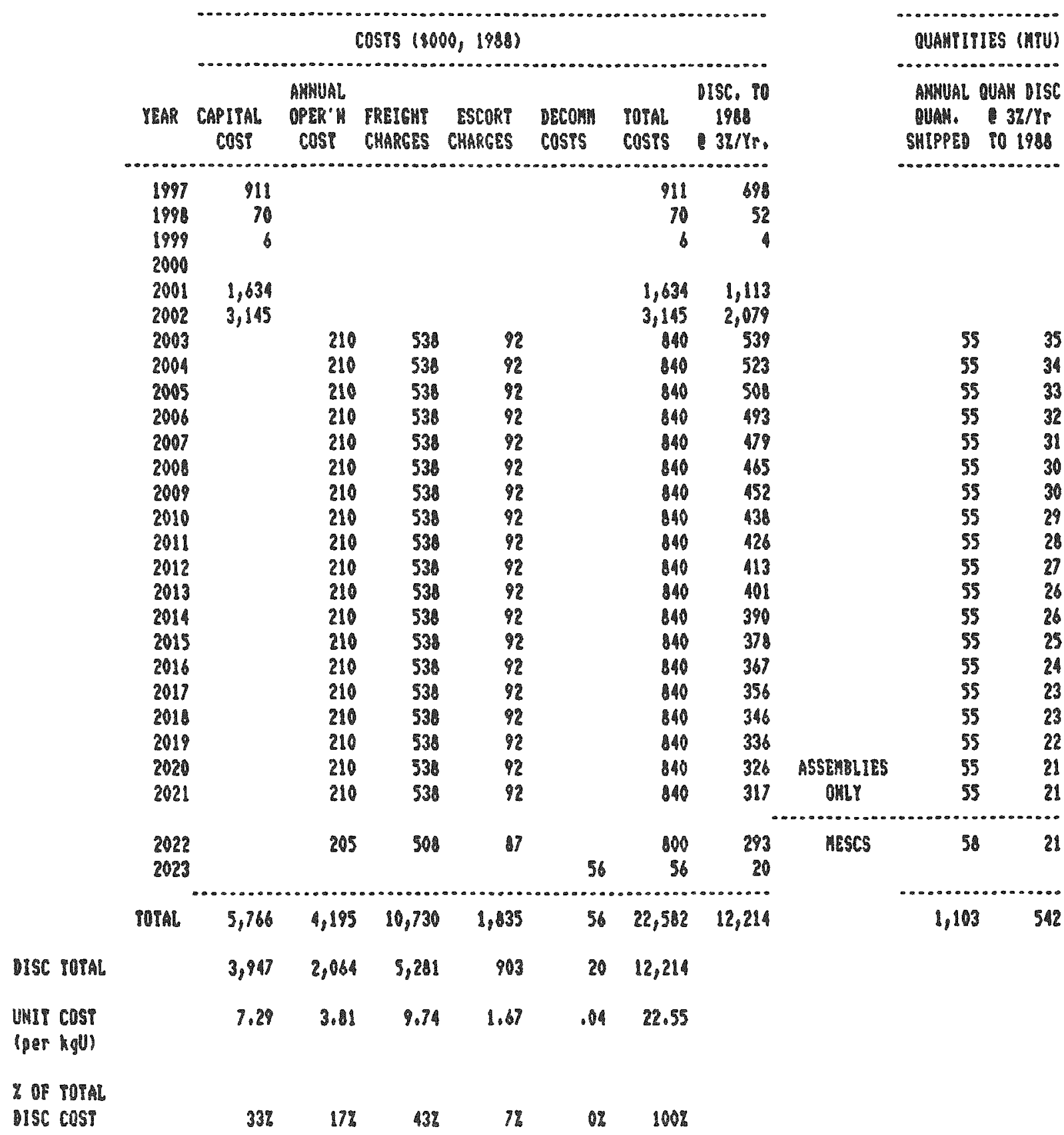


PABLE C-2

CASE 27 -. LIPE CYCLE COSP OF PRAHSPDRI OP 990 MTU AS PUR ASSEMBLIRS AMD 116 MTU AS PHR ASSEMULIES IN MESCS PROH REACTORS TO DOE BACILITIES 500 WILES AWAY IN 1 P PUR ASSEHELY MESC SHIPIHG CASE (ONE KESC CASI IV DOC FLEEI)

\begin{tabular}{|c|c|c|c|c|c|c|c|c|c|c|c|}
\hline & & & & cosis 1000 & $00,1988)$ & & & & & QUAMIIII & IES (MTU) \\
\hline & YTAR & $\begin{array}{c}\text { CAPIIAL } \\
\text { COST }\end{array}$ & $\begin{array}{l}\text { ANUALL } \\
\text { OPER'W } \\
\text { COSY }\end{array}$ & $\begin{array}{l}\text { PREIGH } \\
\text { CHARGES }\end{array}$ & $\begin{array}{l}\text { ESCORI } \\
\text { CHARGES }\end{array}$ & $\begin{array}{l}\text { DECOMH } \\
\text { COSTS }\end{array}$ & $\begin{array}{l}\text { TOTAL } \\
\text { COSTS }\end{array}$ & $\begin{array}{l}15 C .90 \\
1988 \\
13 / \mathrm{Yr}\end{array}$ & & $\begin{array}{l}\text { ANHUAL } \\
\text { BUAM. } \\
\text { SHIPPED }\end{array}$ & $\begin{array}{l}\text { WUAM DISC } \\
\text { 3X/Y } \\
\text { IO } 1988\end{array}$ \\
\hline & 1997 & 911 & & & & & 911 & 698 & & & \\
\hline & 1996 & 70 & & & & & 70 & 52 & & & \\
\hline & 1989 & 6 & & & & & 6 & 4 & & & \\
\hline & 2000 & & & & & & & & & & \\
\hline & 2001 & 1,634 & & & & & 1,834 & 1,113 & & & \\
\hline & 2002 & 3,145 & & & & & 3,145 & 2,879 & & & \\
\hline & 2003 & & 210 & 536 & 82 & & 840 & 539 & & 55 & 35 \\
\hline & 2004 & & 210 & 538 & 92 & & 840 & 523 & & 35 & 34 \\
\hline & 2005 & & 210 & 538 & 92 & & 840 & 508 & & 55 & 33 \\
\hline & 2006 & & 210 & 536 & 92 & & $\$ 40$ & 493 & & 55 & 32 \\
\hline & 2007 & & 210 & 538 & 92 & & 840 & 478 & & 55 & 31 \\
\hline & 2008 & & 210 & 538 & 92 & & 840 & 485 & & 55 & 30 \\
\hline & 2009 & & 210 & 538 & 92 & & 940 & 452 & & 55 & 30 \\
\hline & 2010 & & 210 & 538 & 2 & & 840 & 438 & & 53 & 39 \\
\hline & 2011 & & 210 & 538 & 92 & & 540 & 426 & & 55 & 28 \\
\hline & 2012 & & 210 & 538 & 92 & & 840 & 413 & & 55 & 27 \\
\hline & 2013 & & 210 & 538 & 82 & & 840 & 401 & & 55 & 26 \\
\hline & 2014 & & 210 & 538 & 92 & & 840 & 390 & & 55 & 26 \\
\hline & 2015 & & 210 & 538 & 92 & & 840 & 378 & & 55 & 25 \\
\hline & 2016 & & 210 & 531 & 92 & & 840 & 367 & & 55 & 24 \\
\hline & 2017 & & 210 & 538 & 92 & & 140 & 356 & & 55 & 23 \\
\hline & 2018 & & 210 & 536 & 92 & & 840 & 346 & & 55 & 23 \\
\hline & 2019 & & 210 & ร3) & $9 ?$ & & 840 & 338 & AรSERMBLIES & 5 & 22 \\
\hline & 2020 & & 210 & 538 & 92 & & 840 & 326 & ONL & 55 & 21 \\
\hline & 2021 & & 205 & 500 & 7 & & 800 & 302 & MESCS & 56 & 22 \\
\hline & 2022 & & 205 & 508 & 7 & & 800 & 293 & & 58 & 21 \\
\hline & 2023 & & & & & 56 & 56 & 20 & & & \\
\hline & POTAL & 5,768 & 4,180 & 10,700 & 1,830 & 56 & 22,542 & 12,199 & & 1,106 & 543 \\
\hline DISC POTAl & & 3,947 & 2,062 & 5,268 & 901 & 20 & 12,199 & & & & \\
\hline unlt cost & & 7.27 & 3.10 & 8.70 & 1.66 & .04 & 22.47 & & & & \\
\hline (pers agu & & & & & & & & & & & \\
\hline OP Y0TA & & & & & & & & & & & \\
\hline DIsc CosT & & $39 \%$ & $17 \%$ & 4318 & 79 & $0 \%$ & $100 \%$ & & & & \\
\hline
\end{tabular}


IAILE $C-3$

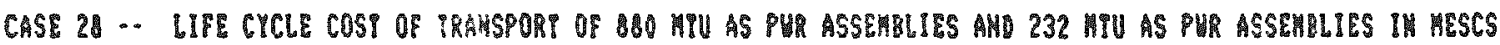
FROM REACTORS TO DOE FACILIIIES SOO IILES AHAY IH 7 PUR ASSEMBLY MESC SHIPIIG CAS (ONE KESC CAST IV DOE FLET)

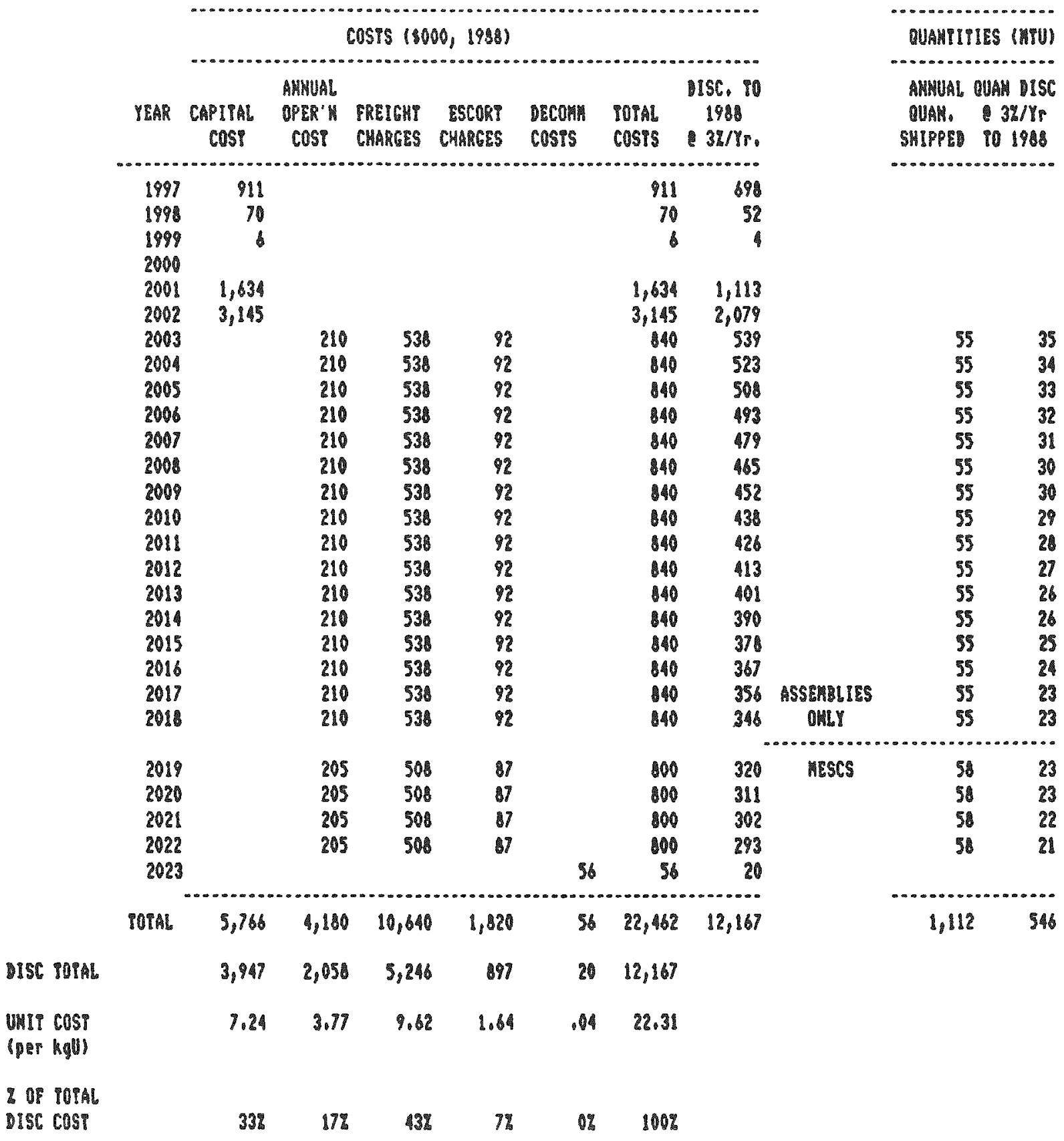


IABLE C-A

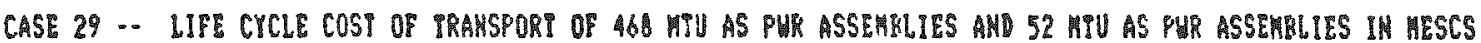

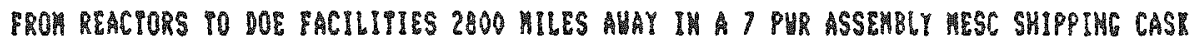
IONE HESC CASL IN DOE FLEPI)

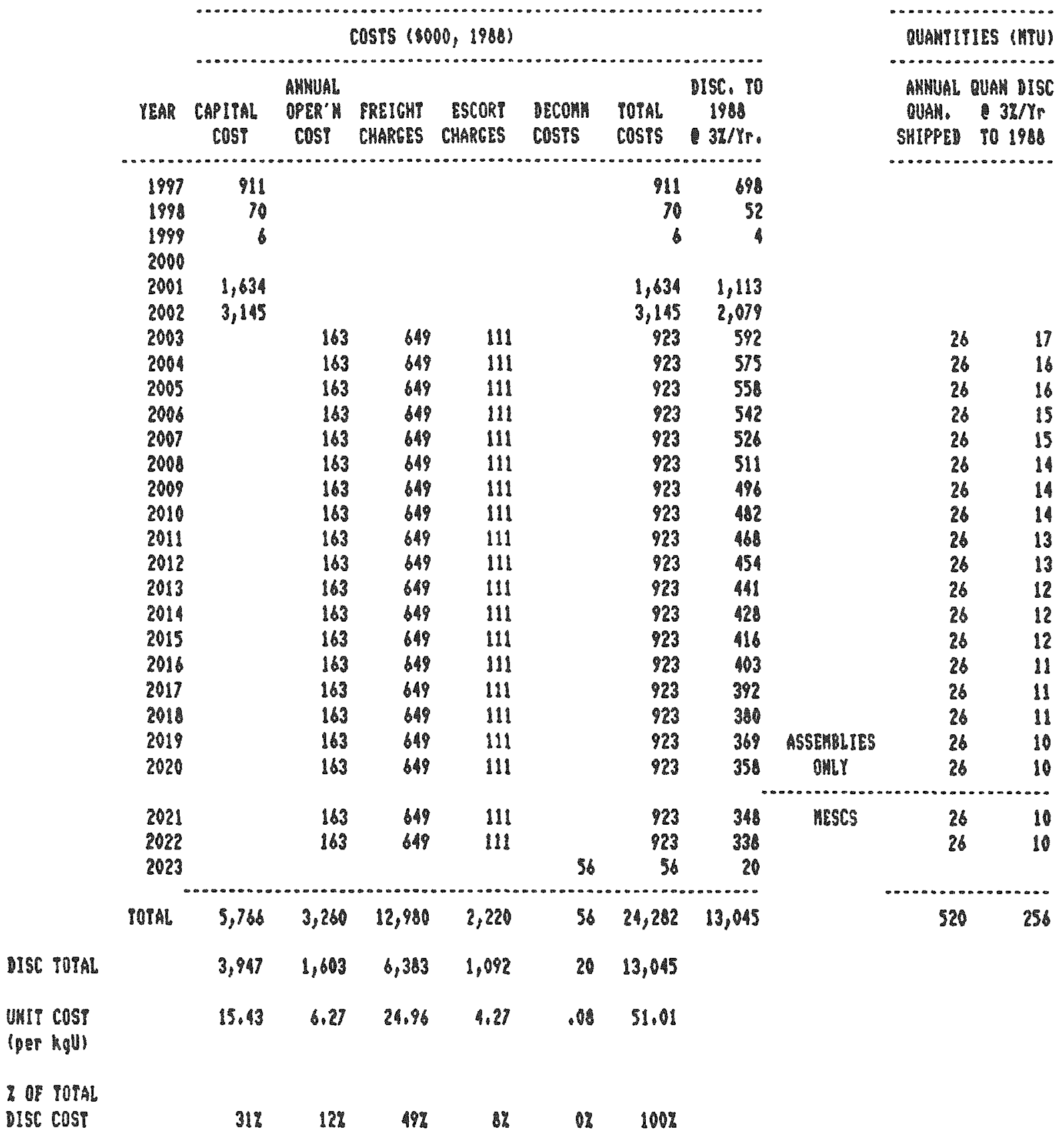


TABLE C-S

CASE 30 - LIFE CYCLE COST OF PRAMSPORT OP 416 HTU AS PUR ASSEMBLIES AMD 104 MTU AS PUR ASSEMBLIES IN MESCS FROH REACTORS TO DOE PACILITIES 2800 MLLS AMAY IU A 7 PU ASSEMBLY MESC SHIPPING CAST (ONE MESC CASI IN DOR PLEET)

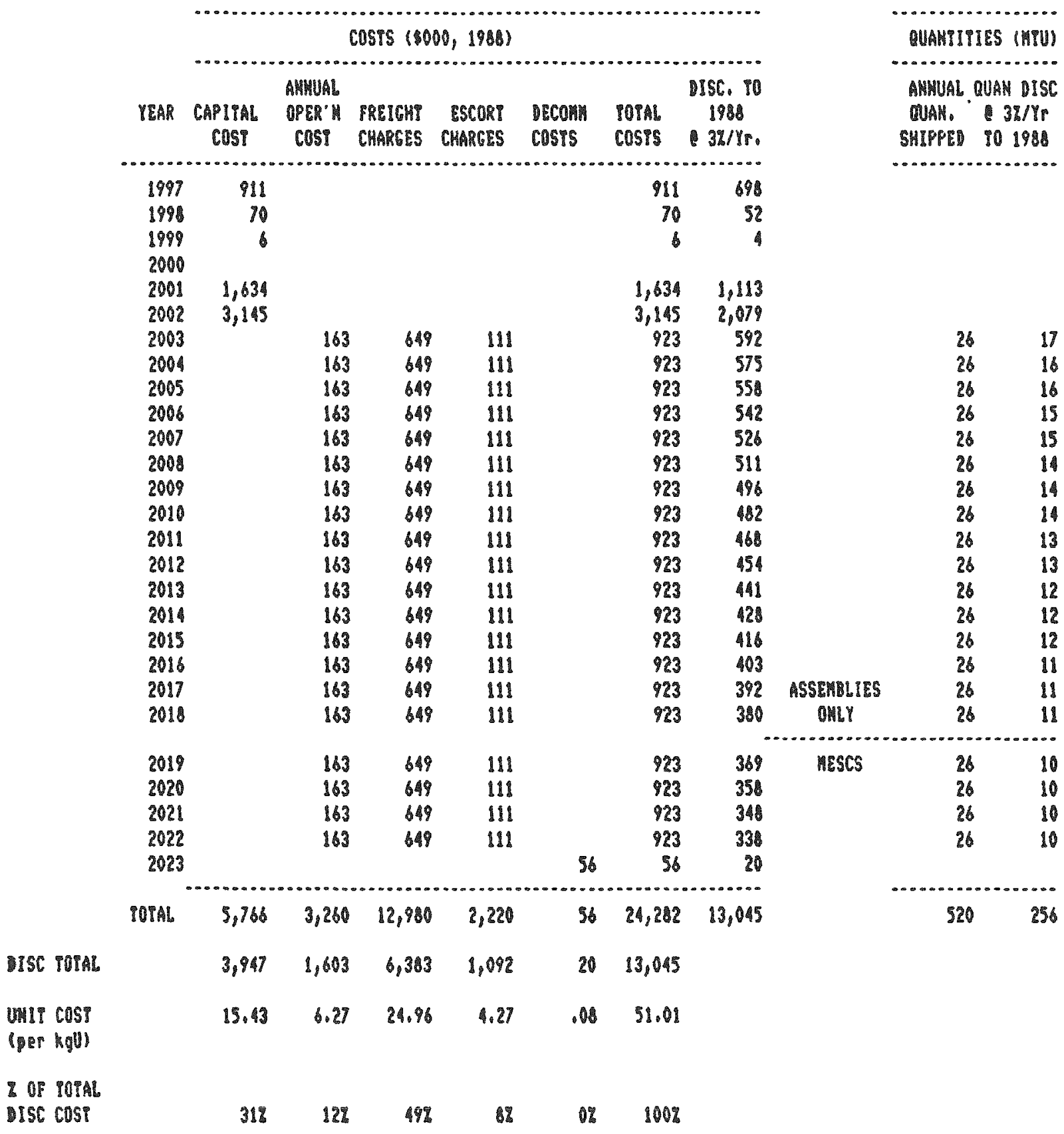


IALLE C-6

CASE 31 - LIFE CYCLE COSY OF TRAMSPORP OP 312 MTI AS PUR ASSEMBLIES AMD 208 MIU AS PUR ASSEHBLIES IN HESCS PROH REACIORS TO DOE FACILITIES 2800 MILES AUAY IN A 7 PUR ASSEHBLY HESC SHIPF:MG CASI

(OHE MESC CASW IN DOE FLEET)

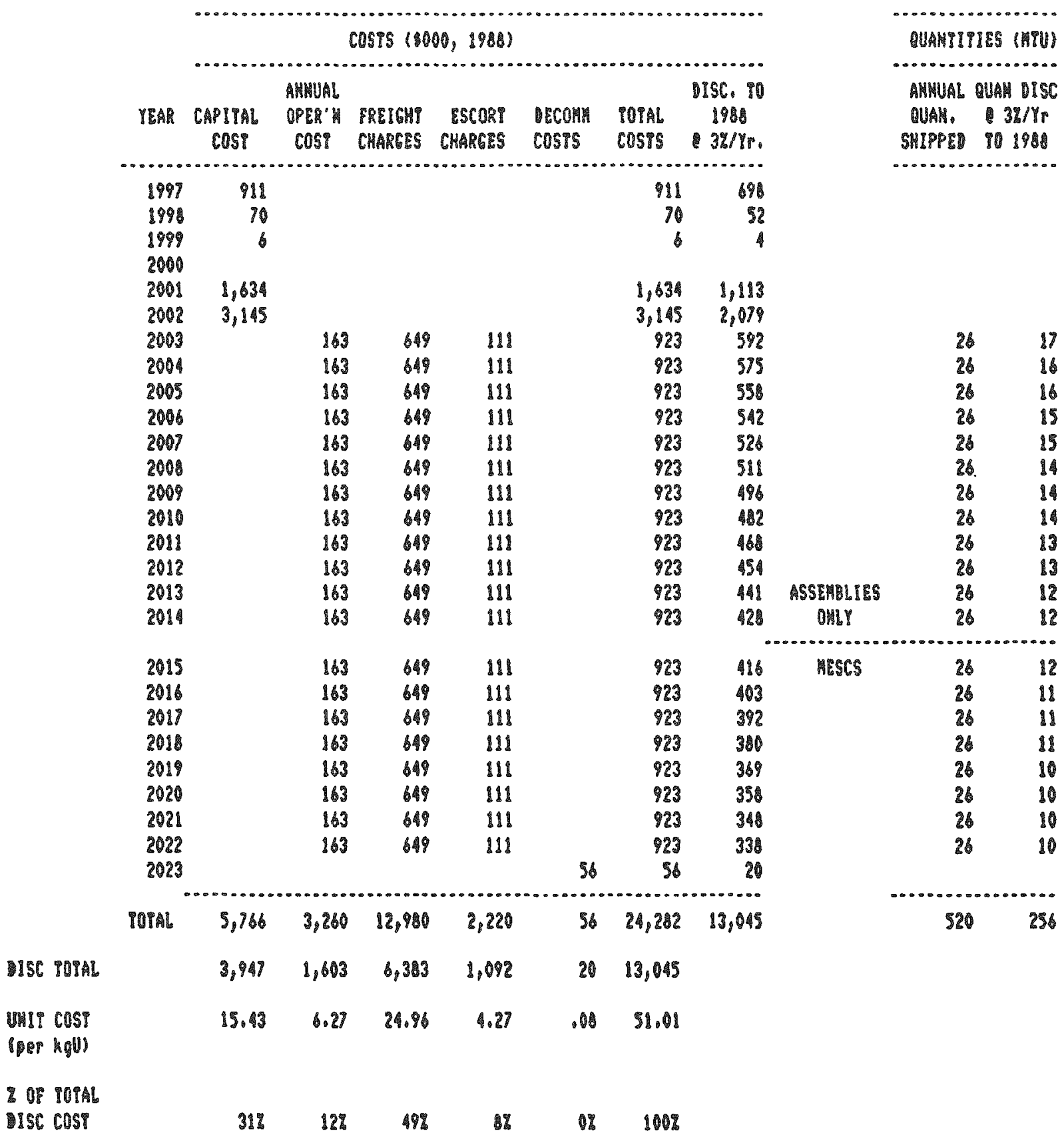


TABLE C.7

CASE 32 - LIFE CYCLE COST OF IRAMSPORT OF 58 MTU AS PUR ASSEMBLIES IN MESCS FROM REACYORS TO DOE BACILITIES 500 MILES AYAY IN A DEOICATED 7 PUR ASSEMBLY MESC SHIPPIHG CASI (ONE MESC CASI IW DOE FLPEI)

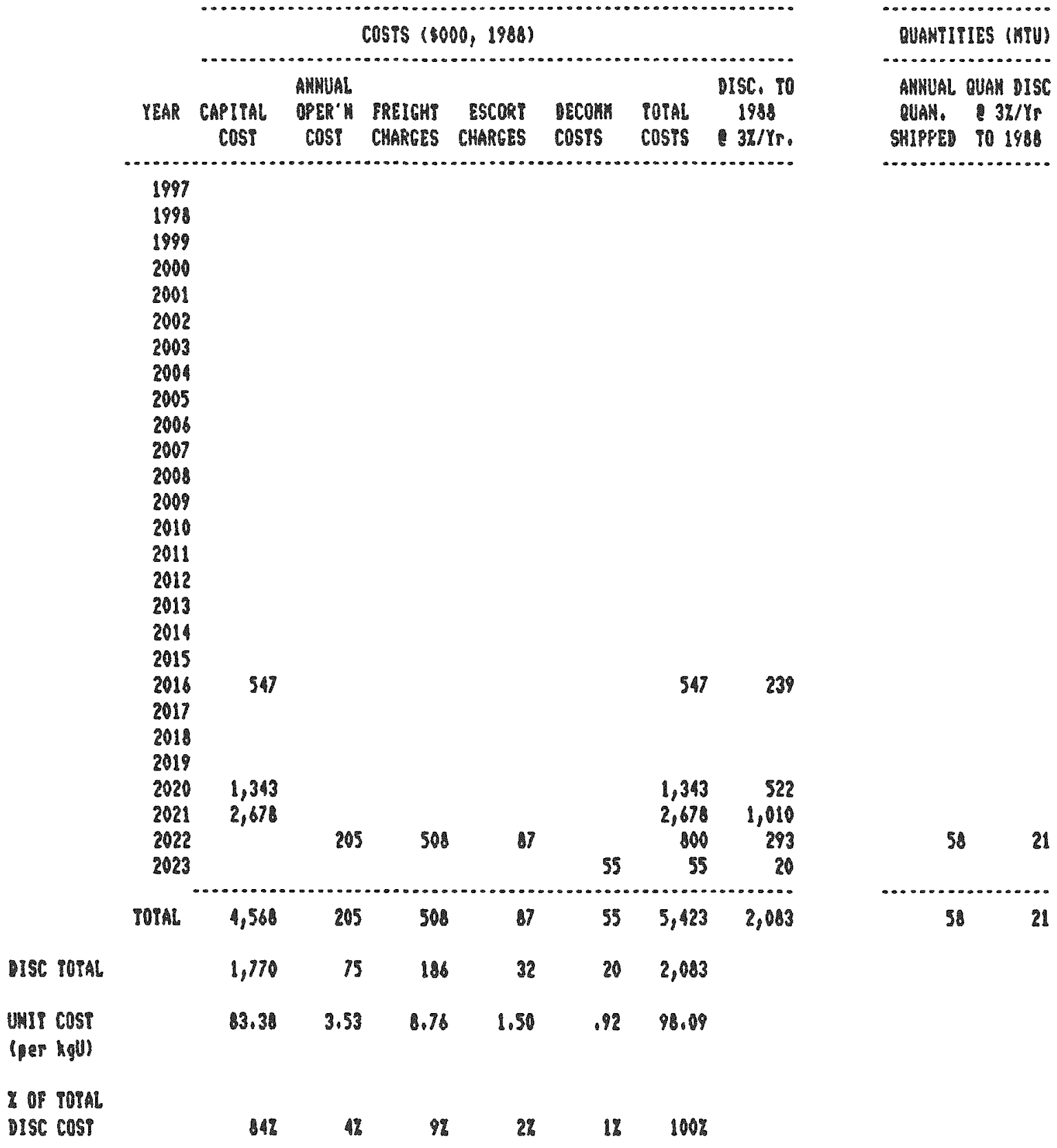


IAELE C-

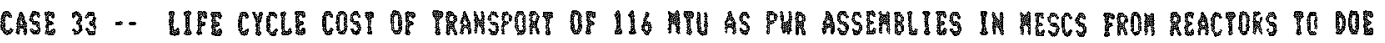
PACILIIIES 500 MULES AHAY IN A UEDICAPED 7 PUR ASSEHBLY HESC SHIPPIUG CAST

COHE MESC CAS IN DOE FLETII

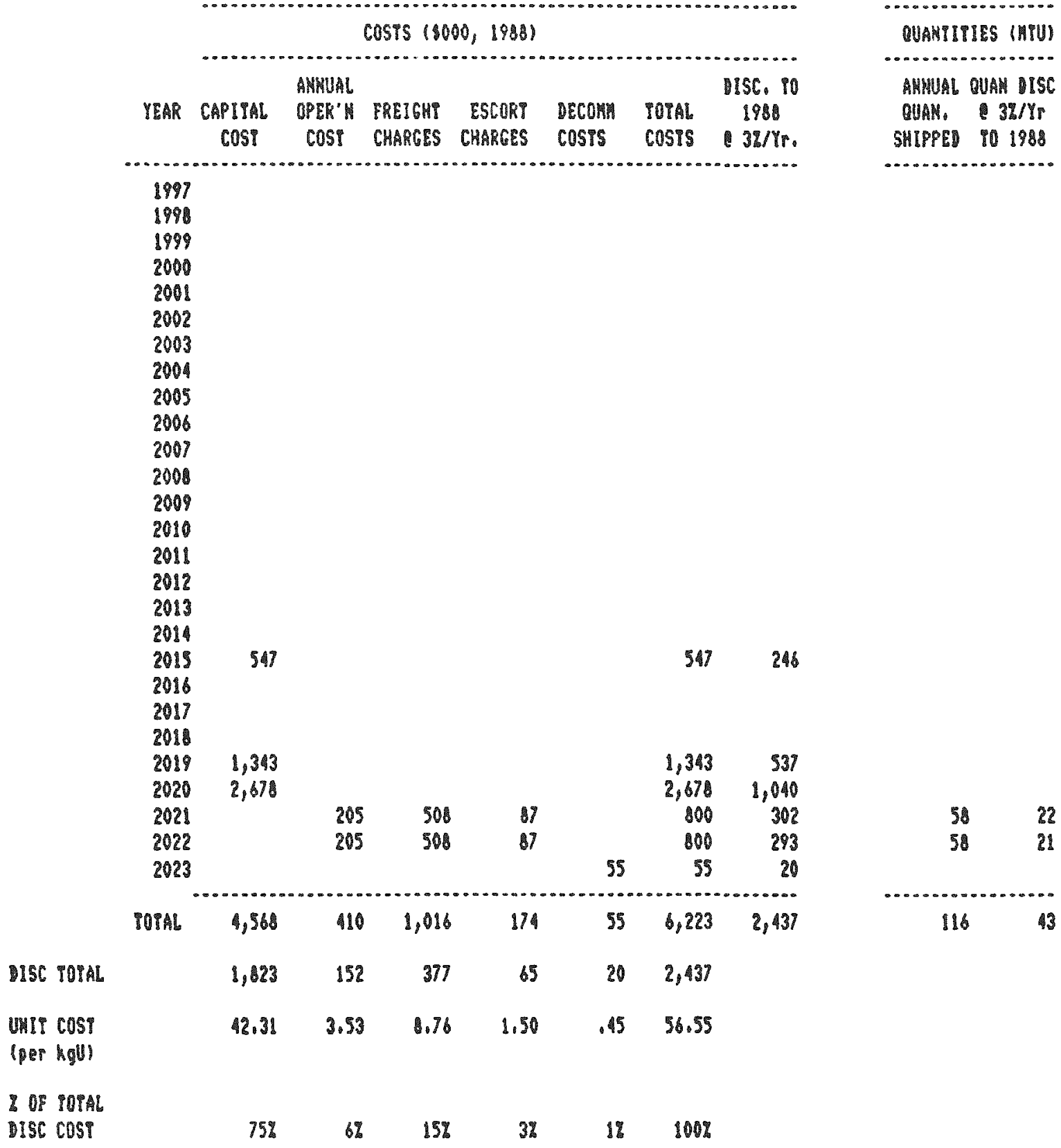


TABLE C-9

CASE 34 - LIFE CYCLE COSI OF IRANSPORI OF 232 MIU AS PUR ASSEMLLIES IN MESCS FROA REACTOKS TO DOE

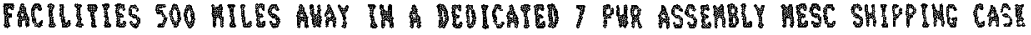

(OHE MESC CASY IH DOC FLEEI)

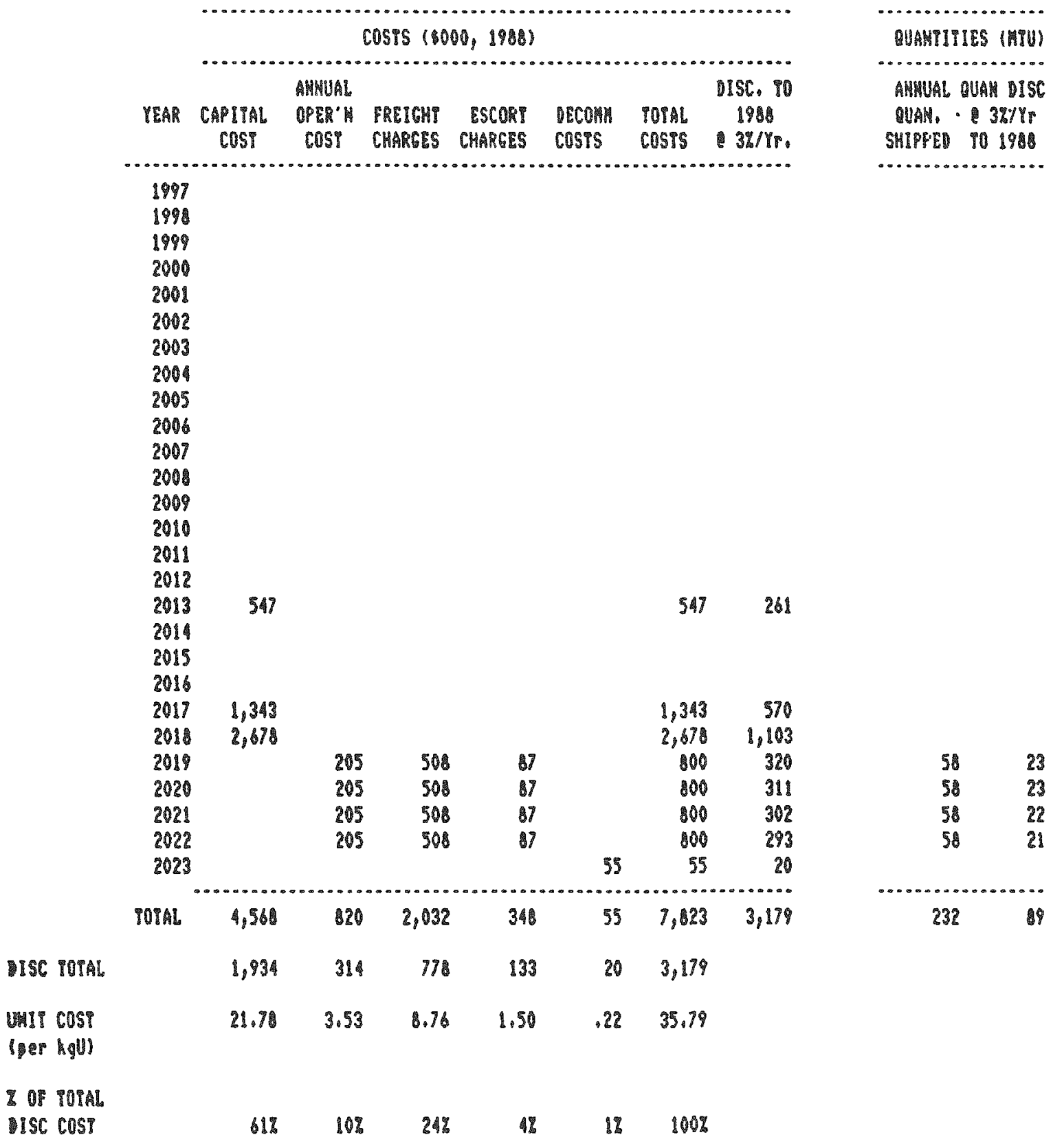


TALLE C-10

CASE 35 -. LIPE CYCLE COST OF TRAMSPORT OS 52 HTV AS PUR ASSEHDLIES IN MESCS PROM REACTORS 10 DOE

PACILITIES 2800 MILES AUAAY IN A DEDICATED 7 PUR ASSERBLY MESC SHIPPIHG CASU (OMR MESC CAS IN DOE FLEET)

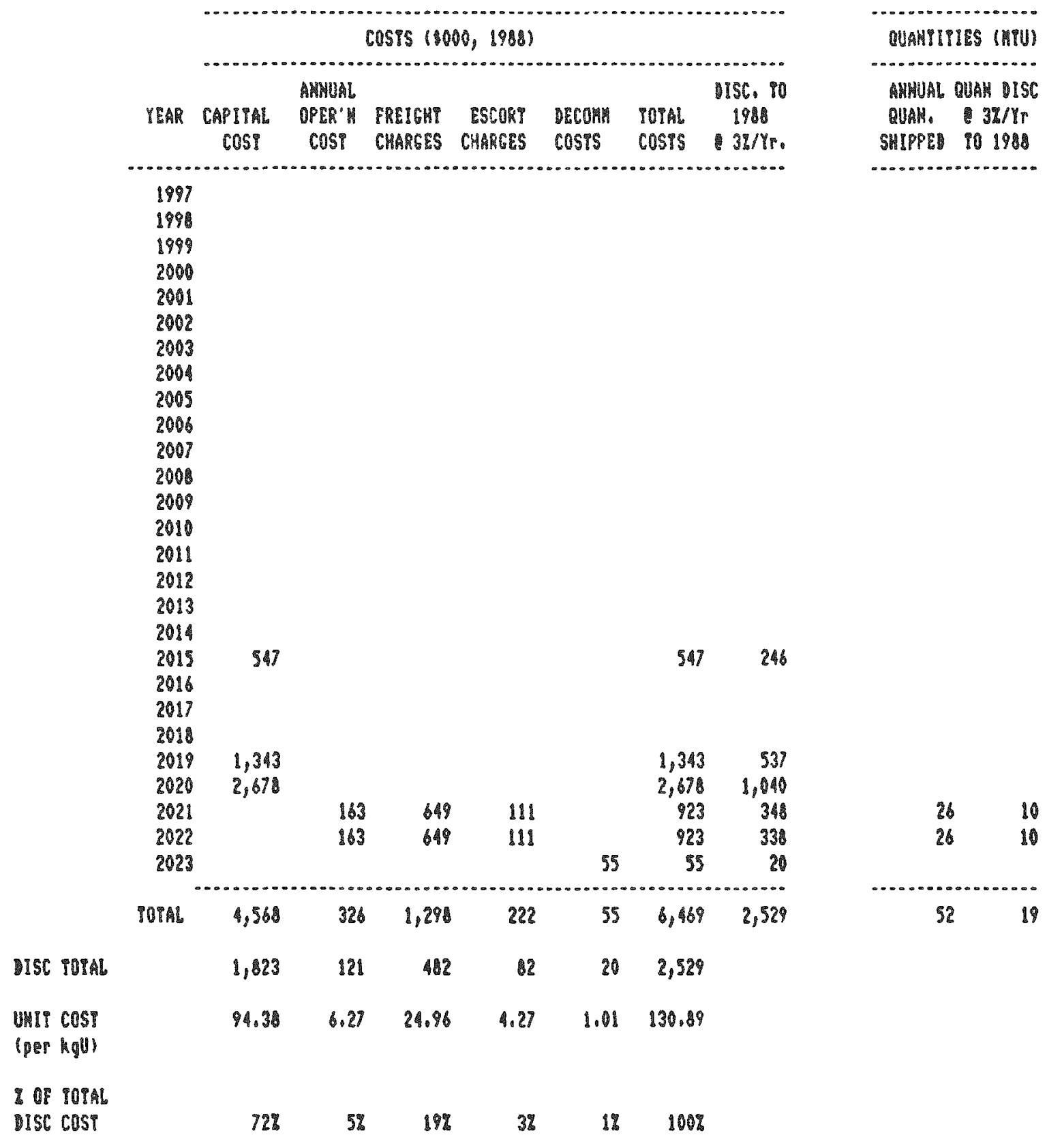


TABLE C-11

CASE 36 - LIFE CYCLE COS OF IKAMSPORI OF 104 MTU AS PUR ASSEMLLIES IN AESCS PROM REACTORS PO DOE PACIUIIIES 2800 MILES AUAY IH AEUICATED 7 PUR ASSEMELY HESC SHIPPIHE CASY IONE MESC CAST IN DOE FLERT)

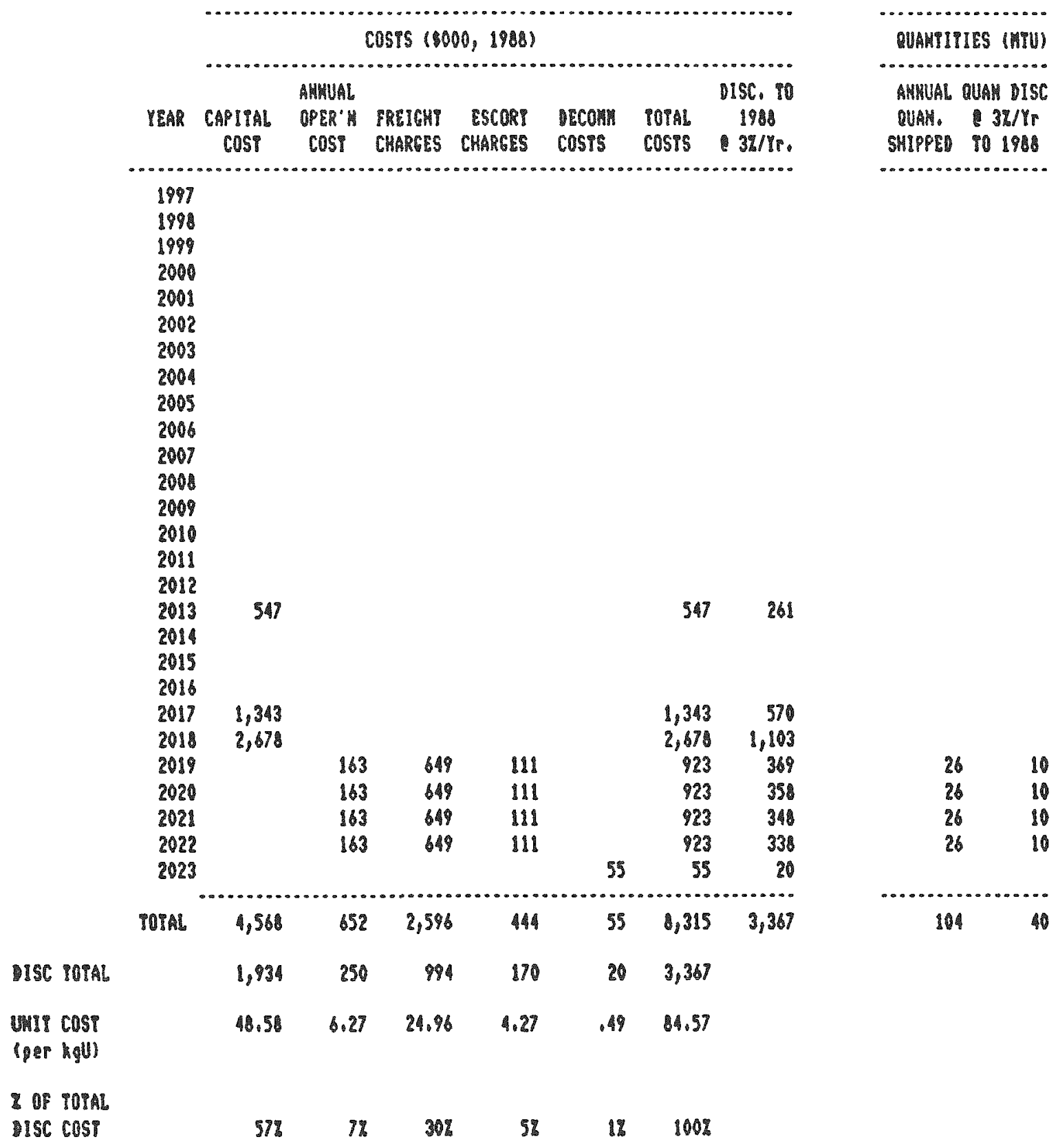


IARL C. 12

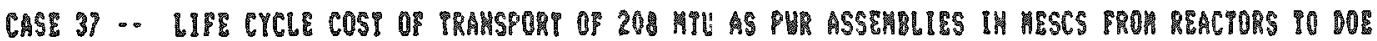
FACILITIES 2800 HILES AYAY IN DEDICATED 7 PUR ASSEHBLY MESC SHIPPING CASE

(ONE MESC CASI IV DOE ELEET)

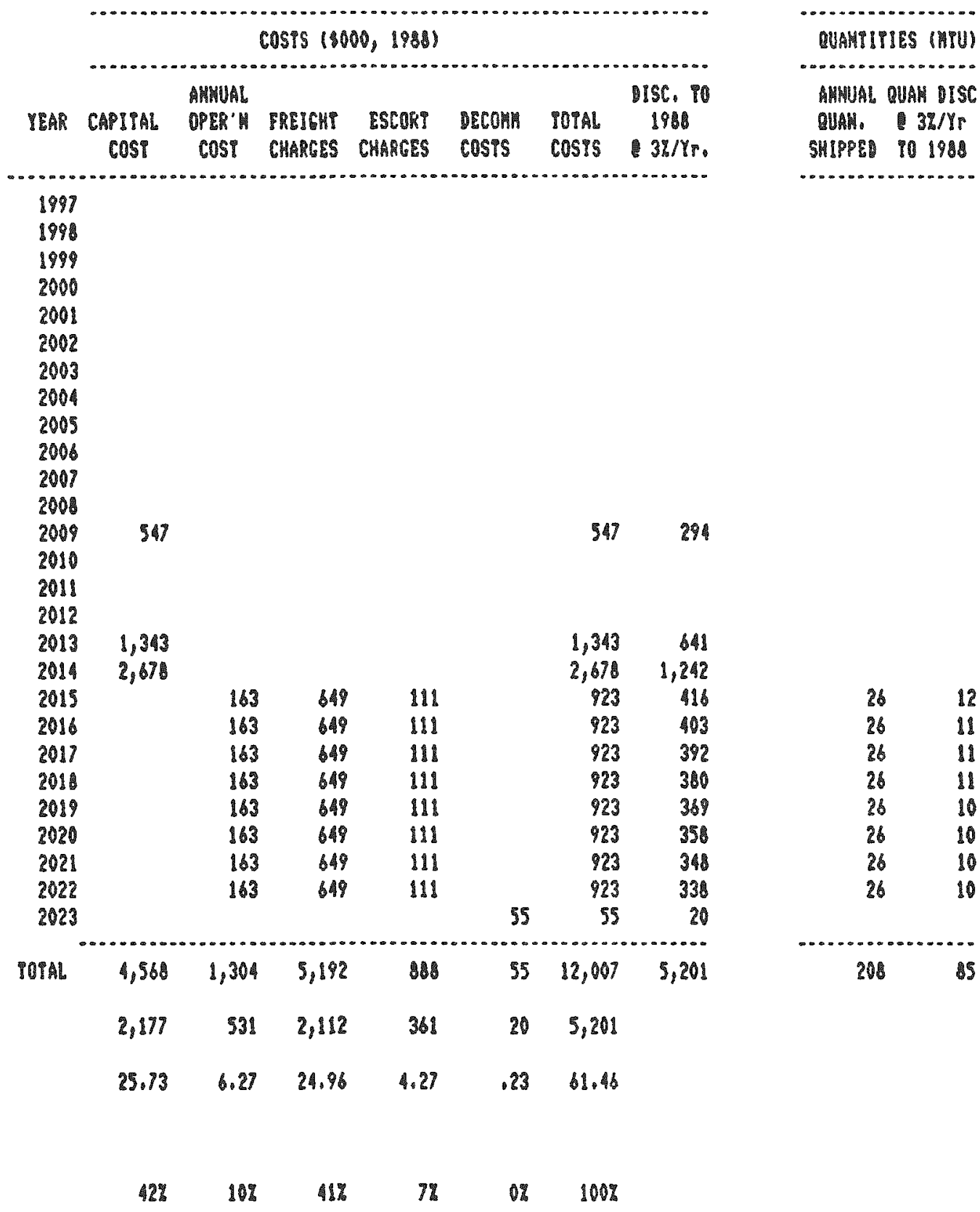


APPENDIX D

LIFE CYCLE TRANSPORT COSTS AND UNIT COST CALCULATIONS

ASSOCIATED WITH THE USE OF A SINGLE $2 / 7$ PWR ASSEMBLY

MESC SHIPPING CASK -- CASKS USED EITHER EXCLUSIVELY FOR

SHIPMENT OF MESCS TO EXTENT AVAILABLE OR FULLY UTILIZED FOR

SHIPMENT OF INDIVIDUAL FUEL ASSEMBLIES AND MESCS 
APPENDIX D

LIFE CYCLE TRANSPORT COSTS AND UNIT COST CALCULATIONS

ASSOCIATED WITH THE USE OF A SINGLE $2 / 7$ PWR ASSEMBLY

MESC SHIPPING CASK -- CASKS USED EITHER EXCLUSIVELY FOR

SHIPMENT OF MESCS TO EXTENT AVAILABLE OR FULLY UTILIZED FOR

SHIPMENT OF INDIVIDUAL FUEL ASSEMBLIES AND MESCS

The total life cycle costs associated with the use of a single 2/7 PWR assembly MESC shipping cask for shipment of varying quantities of spent nuclear fuel from reactors to DOE facilities were developed for instances where ( $i$ ) the cask would be used to ship individual PWR assemblies to the extent there were insufficient MESCs available to fully utilize the cask capacity over its assumed 20-year lifetime, and (ii) the cask would be used to ship only MESCs and thus utilized only to the extent MESCs were available for shipment. The specific cases examined are listed below.

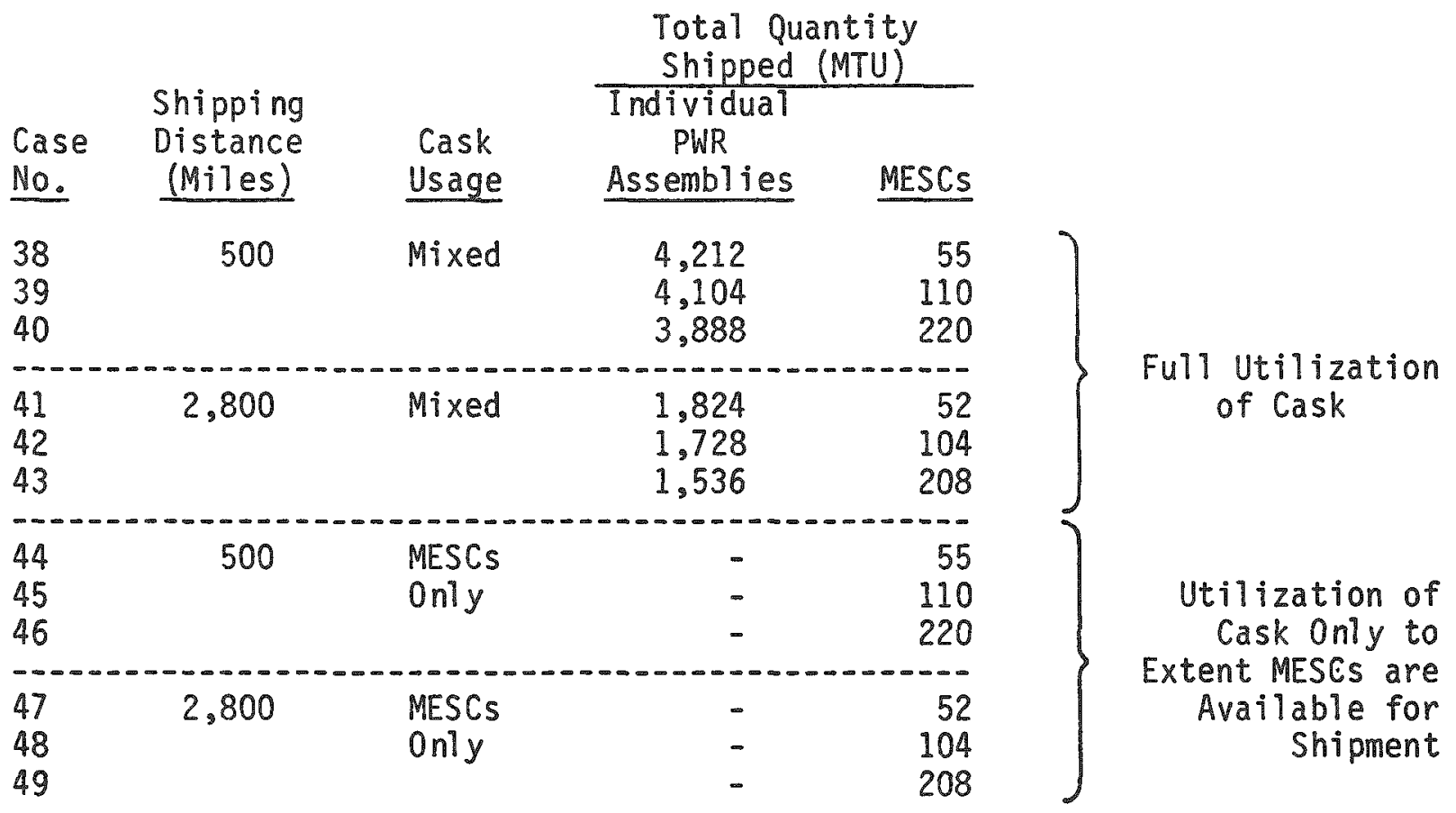


The life cycle costs and resulting unit costs for each of the foregoing cases are shown in Tables $D-1$ through $D-12$. The figures set forth in the tables were developed as follows:

(1) For Cases 38 through 43 where full utilization of the cask over its 1 ifetime was assumed to be achieved, the total costs were assumed to be incurred over the period 1997 to 2023 , inclusive. During the period 1997 through 2002 the capital cost of the cask would be incurred; during the period 2003 through 2022 the cost of operations, freight and escorts would be incurred; and in 2023 the cost of decommissioning would be incurred.

(2) For Cases 44 through 49 where the cask was used for shipment of MESC's only to the extent such were available, the total costs were assumed to be incurred commencing six years prior to the year in which shipments were initiated through 2023. During the first 6 years the capital cost of the cask would be incurred; during the years in which shipments were made the cost of operations, freight and escorts would be incurred; and in 2023 the cost of decommissioning would be incurred.

(3) With regard to the capital cost of the cask, it was assumed that the cost of design and development would be incurred in the first year, the cost of model fabrication and testing would be incurred in the second year (where applicable), the NRC Certification Fee would be paid in the third year (where applicable), half of the cost of cask fabrication would be incurred in the fifth year, and the other half of the cost of fabrication plus the cost of acceptance testing and auxiliary equipment would be incurred in the sixth year. It was assumed that the third and fourth year would be required by NRC to make the necessary safety reviews, and that certification would be made at the end of the fourth year.

(4) The capital cost of the casks for the various cases considered were developed as follows:

(a) For Cases 38-43 in which both shipments of individual fuel assemblies as well as MESCs were involved to achieve full utilization of the cask over its lifetime - the single cask (with basket) capital cost set forth in Table 4-4 was used.

(b) For Cases 44-49 in which shipments of MESCs only were involved and full utilization of the cask was not achieved over its lifetime -- the single cask (without basket) capital cost set forth in Table 4-4 was used, less the allocation for the added costs of the reference cask. Since this cask did not replace a reference cask, but rather constituted an added cask in the fleet, this allocation was not required. 
(5) The annual quantities shipped each year were assumed to be as follows:

Form of

Fuel Shipped

MESCS

Assemblies
MTU in

Single

Shipment

6.45

11.99
Annual Quantity Shipped (MTU)

$500 \quad 2800$

Miles Miles

$110^{*}$

52

216

a Based on 18 shipments/year for 500-mile shipments (17 shipments/year for those cases marked with an asterisk), and 8 shipments/year for 2800-mile shipments.

(6) The annual cost of operation, freight, escorts and decommissioning were determined as described in Section 4.1.2.3.

(7) The total costs were discounted by $3 \% /$ year to 1988 to get the total discounted costs.

(8) The unit costs were determined by dividing the total discounted costs by the total discounted amount (MTU) of spent fuel shipped, as follows:

Discounted Costs $=$ Discounted (Unit Costs $\times$ MTU Shipped)

Discounted Costs $=$ Unit Costs $\times$ Discounted MTU Shipped

Unit Cost $=$ Discounted Costs Discounted MTU Shipped

A more detailed explanation of the methodology used for the unit cost calculation is set forth in Appendix F. 
IABLS D.1

CASE 38 - LUPE CYCLE COSI OF TRAMSPOKT OF 4212 MTU AS PMR ASSEMBLIES AMD 55 MTU AS PUR ASSEMB:IES IN HESCS FROM REACTORS TO DOE PACIUUTIES SOO HILES AMAY IV A $2 / 7$ PUR ASSEHBLY HESC SHIPPING CASE COHR HESC CASI IM DOE RLEET!

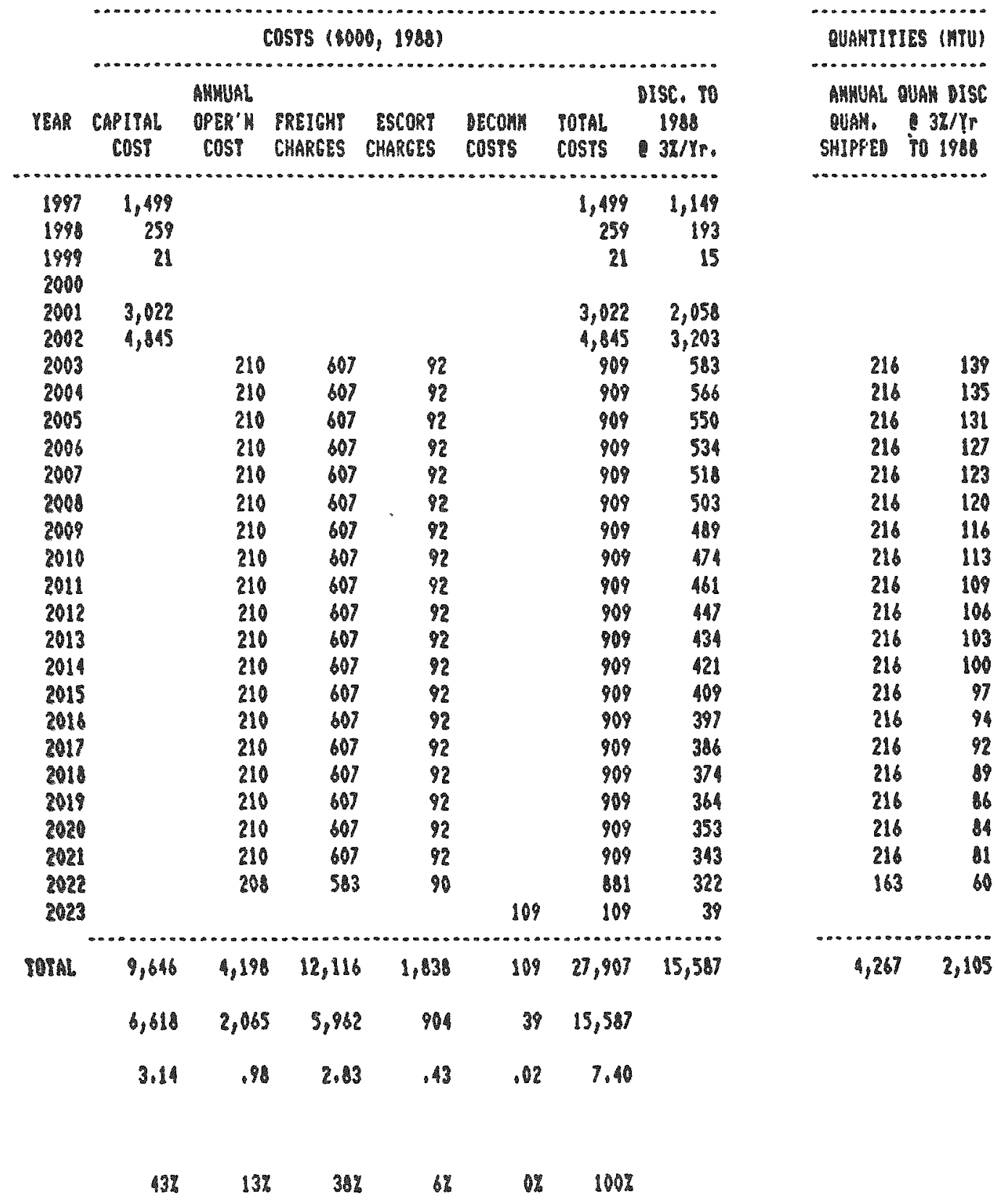


TABLE D

CASE 39 LIF CICLE COST OF TRAMSPORI OF 104 MTU AS PUR ASSEMBLIES AWD 110 WIU AS PUR ASSEMLIES IN MESCS

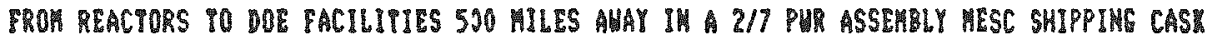
(ONE HESC CASY IM DOC FLEET)

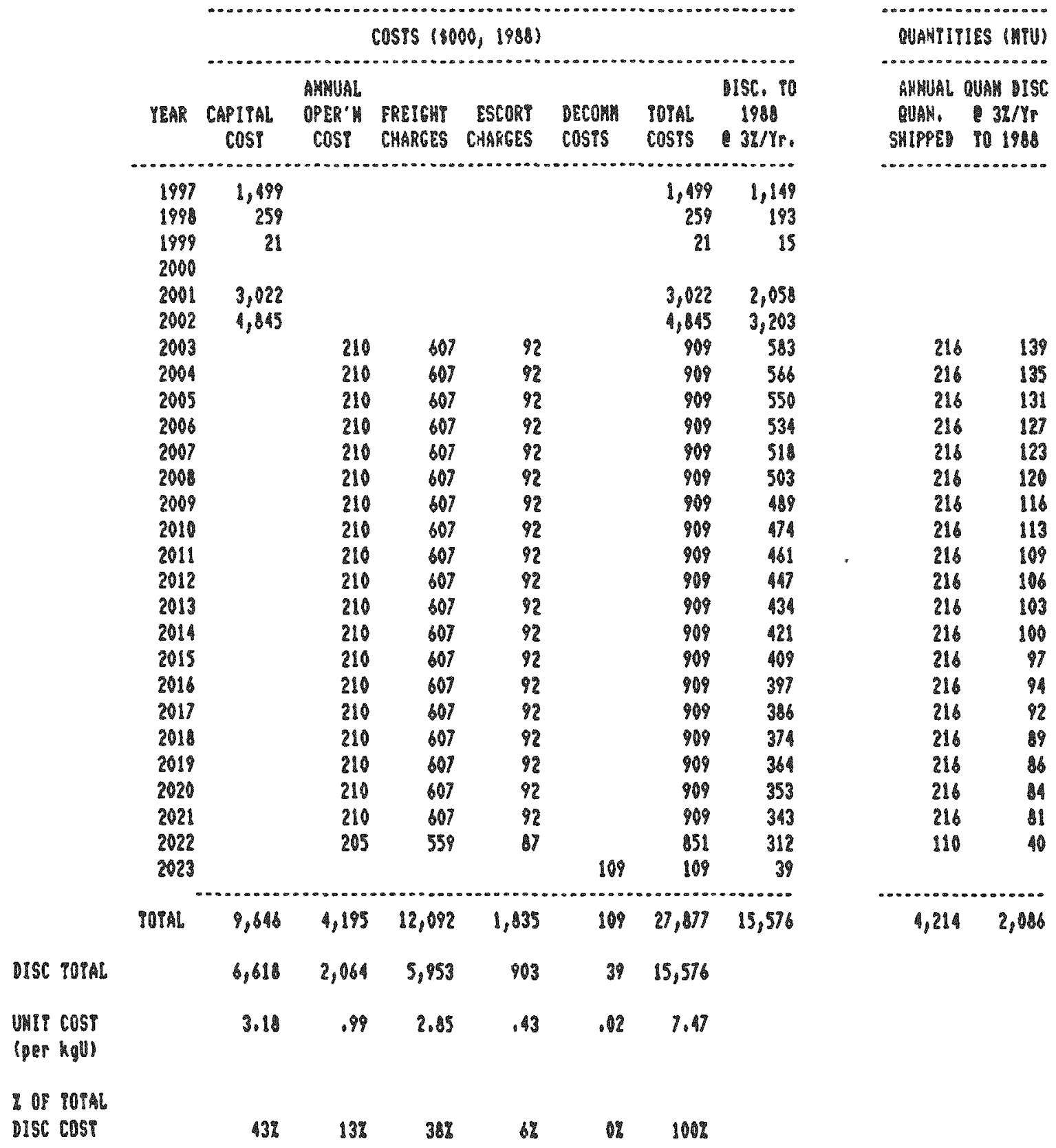


IABS D-3

CASE 40 - LIFE CYCLE COSP OF IRANSPORT OF 3800 MTU AS PUR ASSEMBLIES AMD 220 NTU AS PUR ASSEMBLYES IN MESCS

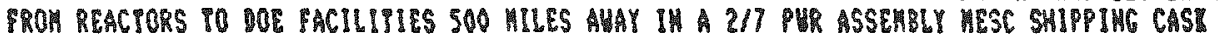

OONE RESC CASI IN DOE RLEES

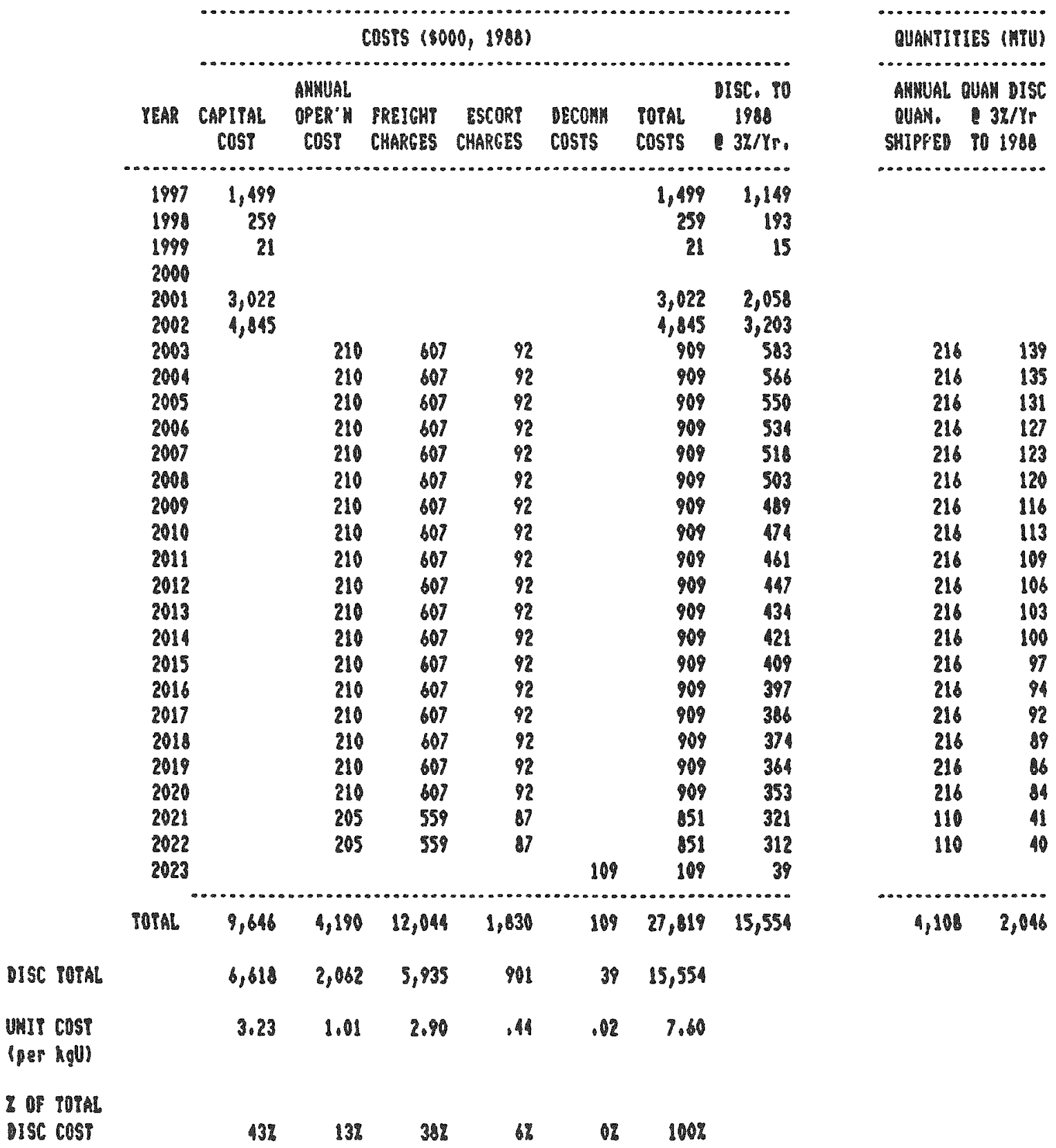


TASLC D-

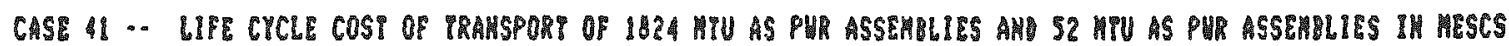

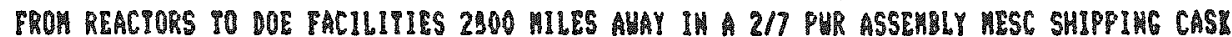
IOHE MESC CASI IIH DOE PLEEI

\begin{tabular}{|c|c|c|c|c|c|c|c|c|c|c|}
\hline & & $\ldots$ & $=\infty+\infty, \infty)-\infty$ & COSTS 110 & 70,1988 & ......... & .... & $\ldots \ldots$ & WUAMTII & IES (TIVU) \\
\hline & & $0 \ldots$ & 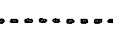 & & & & $\ldots$ & 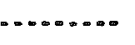 & Ansonon & \\
\hline & IEAR & $\begin{array}{c}\text { CAPIPAL } \\
\text { COSP }\end{array}$ & $\begin{array}{c}\text { AHUUAL } \\
\text { OPER" } \\
\text { COST }\end{array}$ & $\begin{array}{l}\text { PREIGHT } \\
\text { CHARGES }\end{array}$ & $\begin{array}{l}\text { EScOR } \\
\text { CHARGES }\end{array}$ & $\begin{array}{l}\text { acomin } \\
\text { costs }\end{array}$ & $\begin{array}{l}\text { POTAL } \\
\text { Cosis }\end{array}$ & $\begin{array}{c}\text { DS6. } 10 \\
1985 \\
32 / 17 .\end{array}$ & $\begin{array}{l}\text { AHMUAL } \\
\text { OUAN. } \\
\text { SHIPPES }\end{array}$ & $\begin{array}{c}\text { OUAN DISC } \\
32 / Y \mathrm{P} \\
\text { TI } 1980\end{array}$ \\
\hline & $\cdots \ldots . .$. & $\ldots \ldots$ & 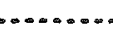 & $=\ldots \ldots$ & . & & W...... & ............. & $\ldots$ & 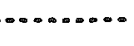 \\
\hline & 1997 & 1,198 & & & & & 1,489 & 1,149 & & \\
\hline & 1998 & 258 & & & & & 258 & 193 & & \\
\hline & $\begin{array}{l}1999 \\
2000\end{array}$ & 21 & & & & & 21 & 15 & & \\
\hline & 2001 & 3,022 & & & & & 3,022 & 2,056 & & \\
\hline & 2002 & 4,845 & & & & & 1,645 & 3,203 & & \\
\hline & 2003 & & 143 & 733 & 111 & & 1,007 & 64 & 9 & 62 \\
\hline & 2004 & & 163 & 733 & 111 & & 1,007 & 628 & 9 & 60 \\
\hline & 2005 & & 163 & 733 & 111 & & 1,007 & 809 & 96 & 56 \\
\hline & 2006 & & 163 & 733 & 111 & & 1,007 & 592 & 98 & 56 \\
\hline & 2007 & & 163 & 733 & 111 & & 1,007 & 574 & 96 & 35 \\
\hline & 2008 & & 163 & 733 & 111 & & 1,007 & 558 & 96 & 53 \\
\hline & 2009 & & 163 & 733 & 111 & & 1,007 & 541 & 86 & 52 \\
\hline & 2010 & & 163 & 733 & 111 & & 1,007 & 526 & 96 & 50 \\
\hline & 2011 & & 163 & 733 & 111 & & 1,007 & 580 & 96 & 49 \\
\hline & 2012 & & 163 & 733 & 111 & & 1,007 & 495 & 96 & 47 \\
\hline & 2013 & & 163 & 733 & 111 & & 1,007 & 481 & 86 & 48 \\
\hline & 2014 & & 13 & 733 & 111 & & 1,007 & 167 & 96 & 45 \\
\hline & 2015 & & 103 & 733 & 111 & & 1,007 & 453 & 86 & 43 \\
\hline & 2016 & & 163 & 733 & 111 & & 1,007 & 440 & 96 & 42 \\
\hline & 2017 & & 163 & 733 & 111 & & 1,007 & 27 & 96 & 41 \\
\hline & 2018 & & 163 & 733 & 111 & & 1,607 & 48 & 8 & 40 \\
\hline & 2018 & & 163 & 733 & 111 & & 1,007 & 403 & 86 & 36 \\
\hline & 2020 & & 163 & 733 & 111 & & 1,007 & 391 & 96 & 37 \\
\hline & 2021 & & 163 & 733 & 111 & & 1,007 & 300 & 96 & 36 \\
\hline & 2022 & & 163 & 715 & 111 & & 919 & 362 & 52 & 19 \\
\hline & 2023 & & & & & 109 & 109 & 39 & & \\
\hline & POTAL & 9.646 & 3,260 & 14,642 & 2,220 & 109 & 29.877 & 16,554 & 1,876 & 926 \\
\hline DISC IOTAL & & 6,618 & 1,603 & 7,203 & 1,082 & 39 & 16,554 & & & \\
\hline $\begin{array}{l}\text { Uhet cosp } \\
\text { (per hgul }\end{array}$ & & 7.13 & 1.73 & 7.76 & 1.10 & .61 & 17.64 & & & \\
\hline of & & & & & & & & & & \\
\hline ISC COST & & $40 \%$ & $10 \%$ & 132 & $7 \%$ & $0 \%$ & $100 \%$ & & & \\
\hline
\end{tabular}


IAR: D-S

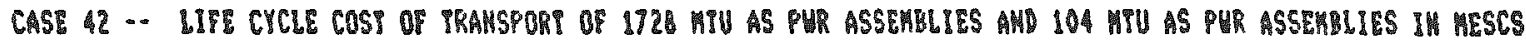

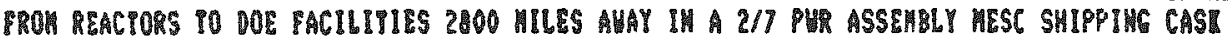
IOME MESC CASY IN DOE VLEETI

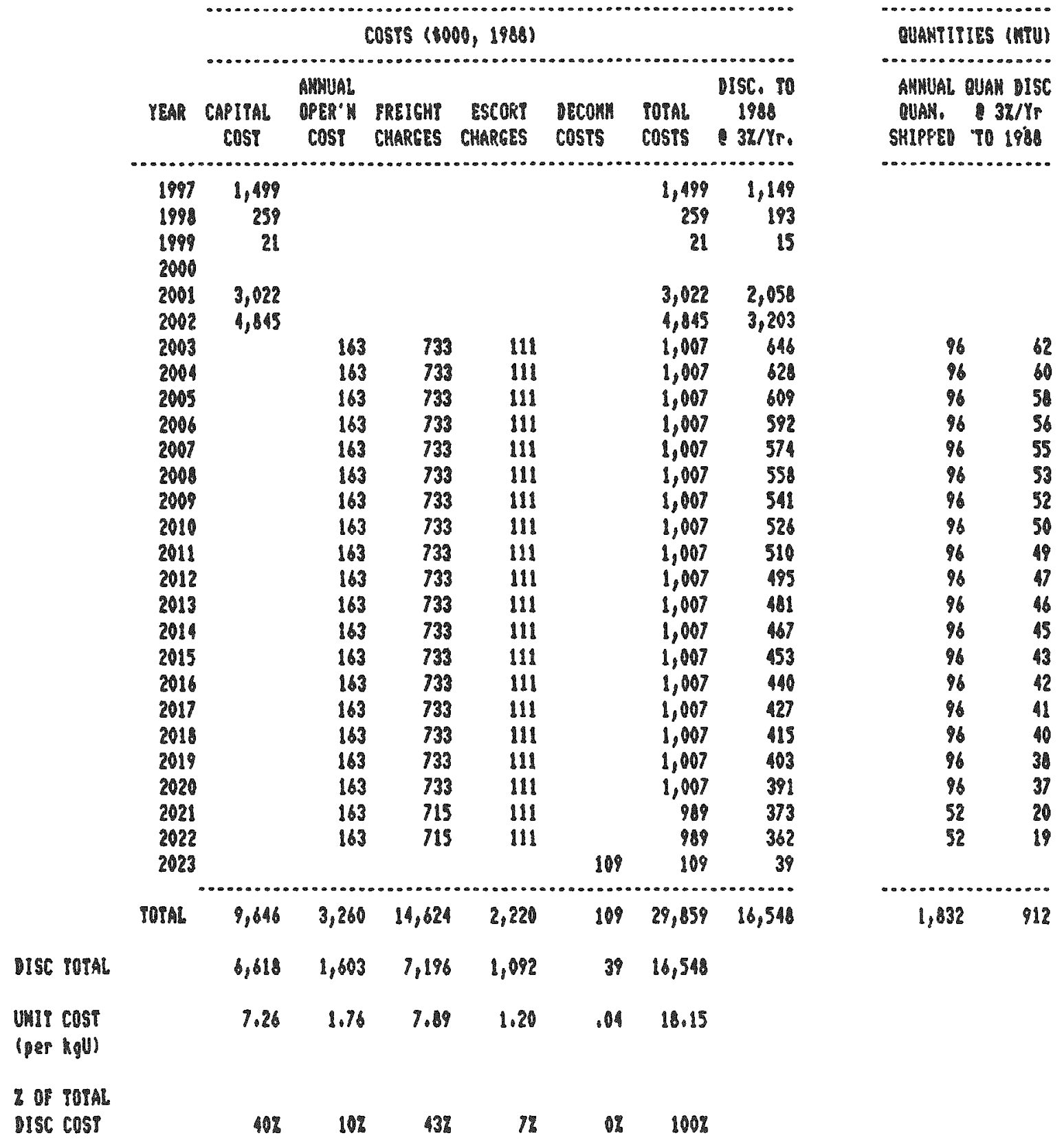


IALLE D-6

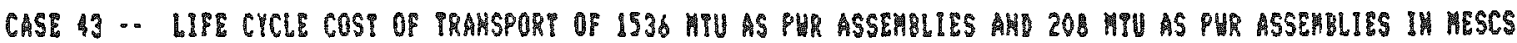
PRON REACYORS TO DOE PACILITIES 2300 MLLES AHAY IN A $3 / 7$ PUR ASSEMBLY HESC SHIPPIHG CASR

(ONE MESC CASI IH DOE PLEET)

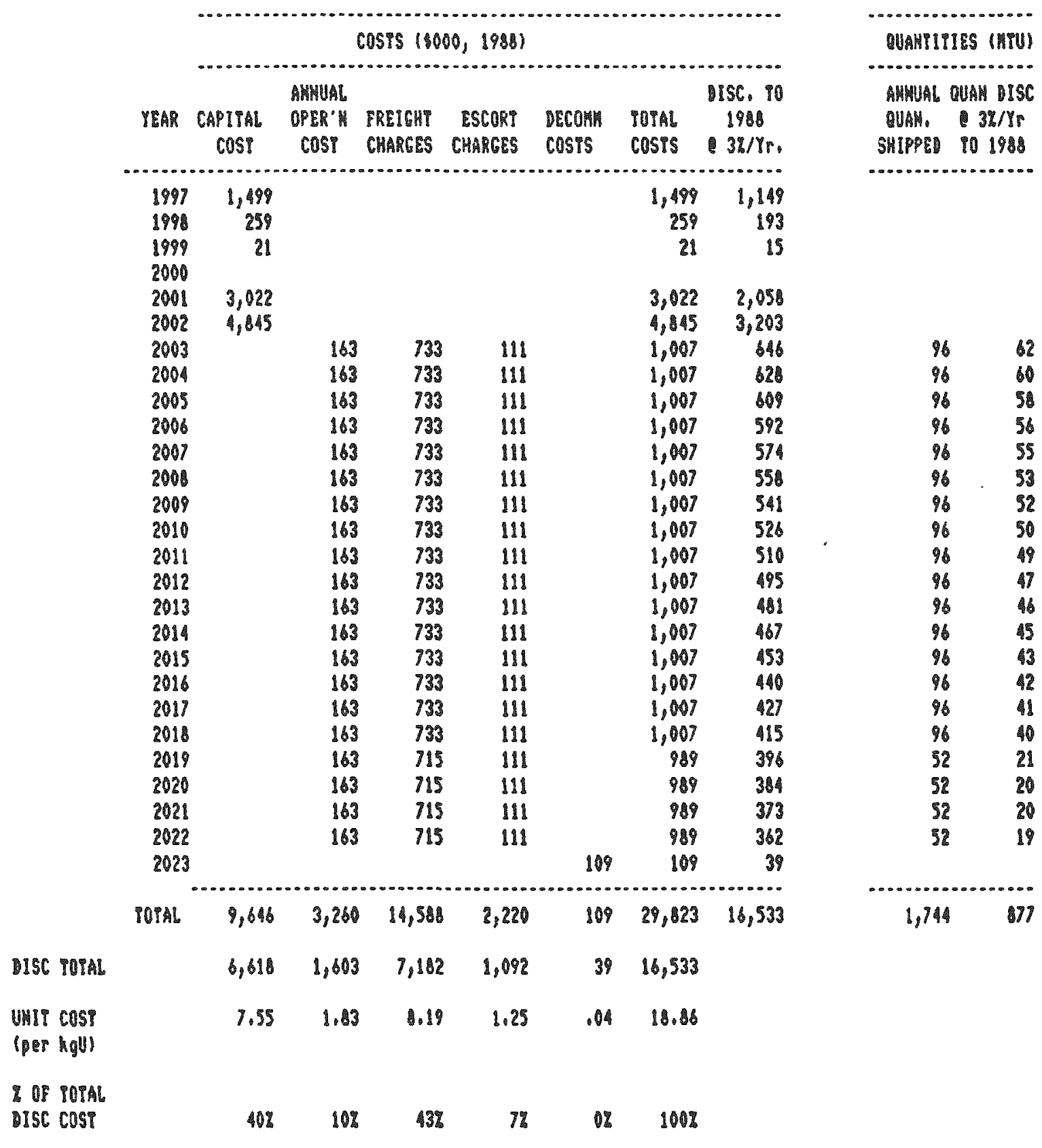


TABLE $1-7$

CASE - LIFE CYCLE COST OP TRAMSPURT OF 55 MTU AS PUR ASSEMLIES IN MESCS FRON REACTORS PO DOE

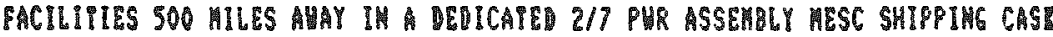

IOHE MESC CASS IN DOE TLEEI)

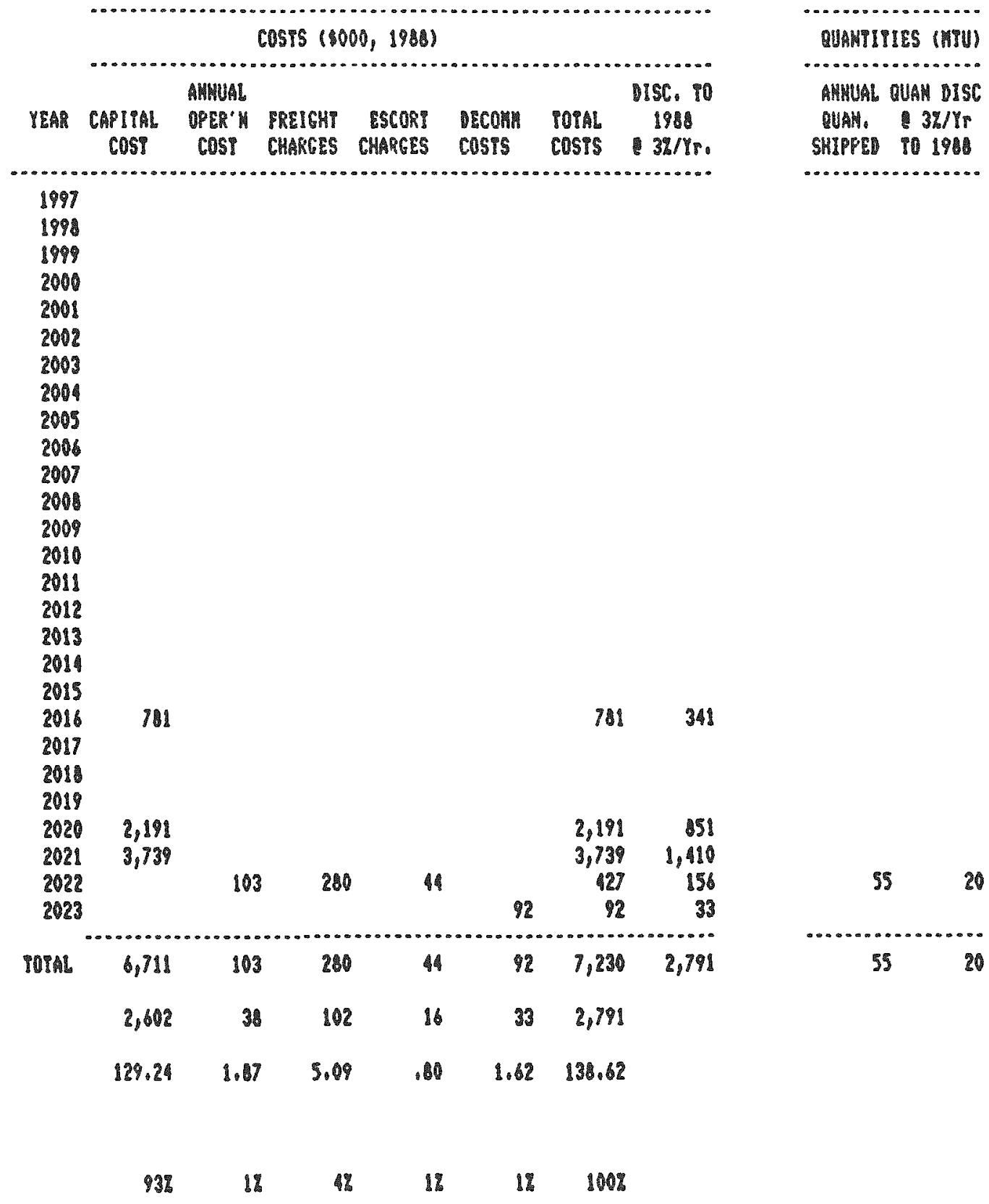


TASLE D-

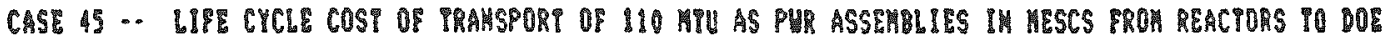
PACIUIIIES 500 MILES AUAY IN A IEDICATED 27 PUR ASSEMBLY HESC SHIPPIMG CAST CONE AESC CASY IV DOE PLEEI

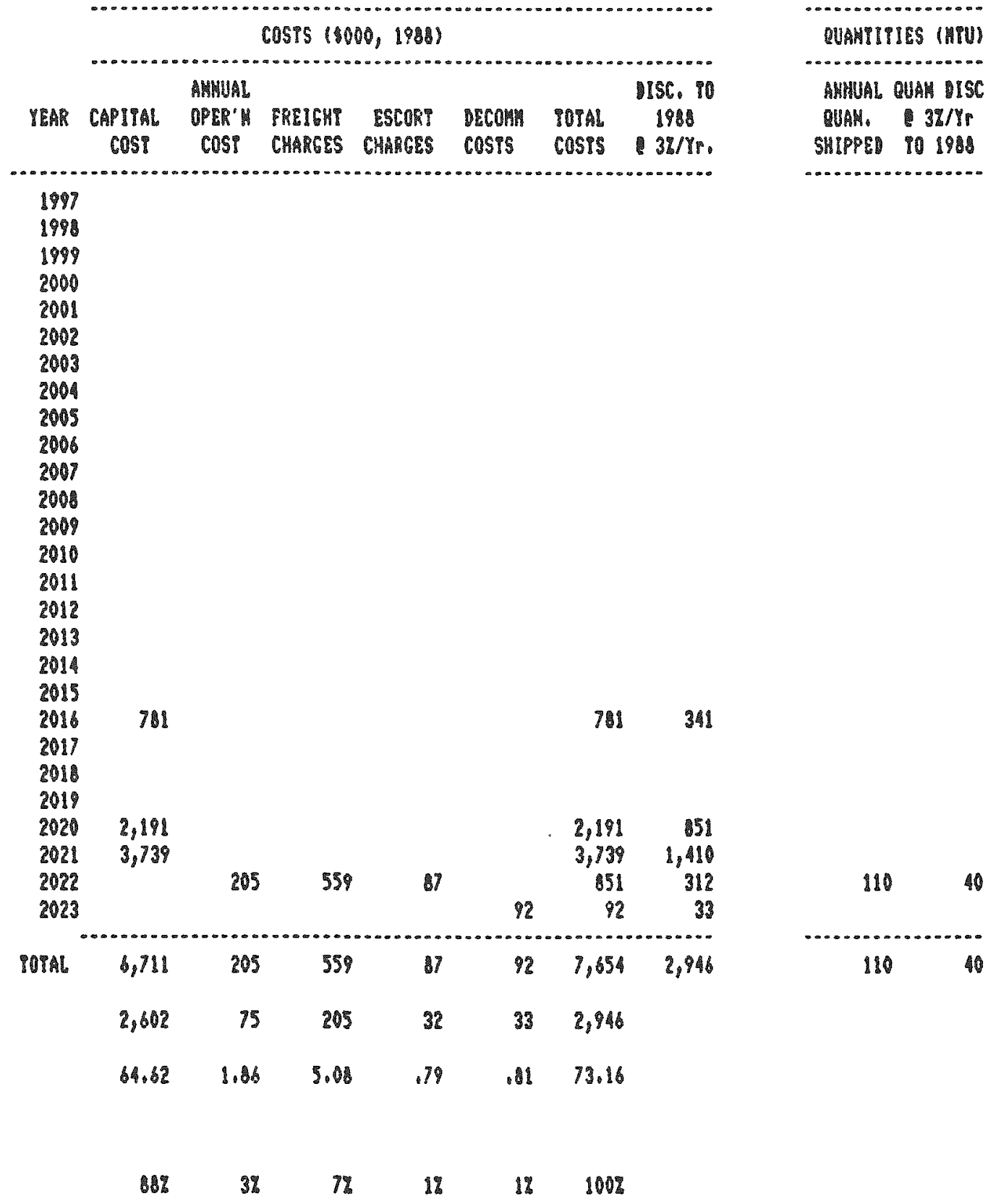


IAB:

CASE 46 - LIFE CYCLE COSI OF PRAMSPORI OF 220 MIU AS PUR ASSRHELIES IN MESCS FROH REACPORS TO DOE PACILIPIES SOO HILES AWAY IM A DEDICAPRD $2 / 7$ PUR ASSEHBLY HESC SHIPPING GASP YONE MESC CASI IN DOE RLETI

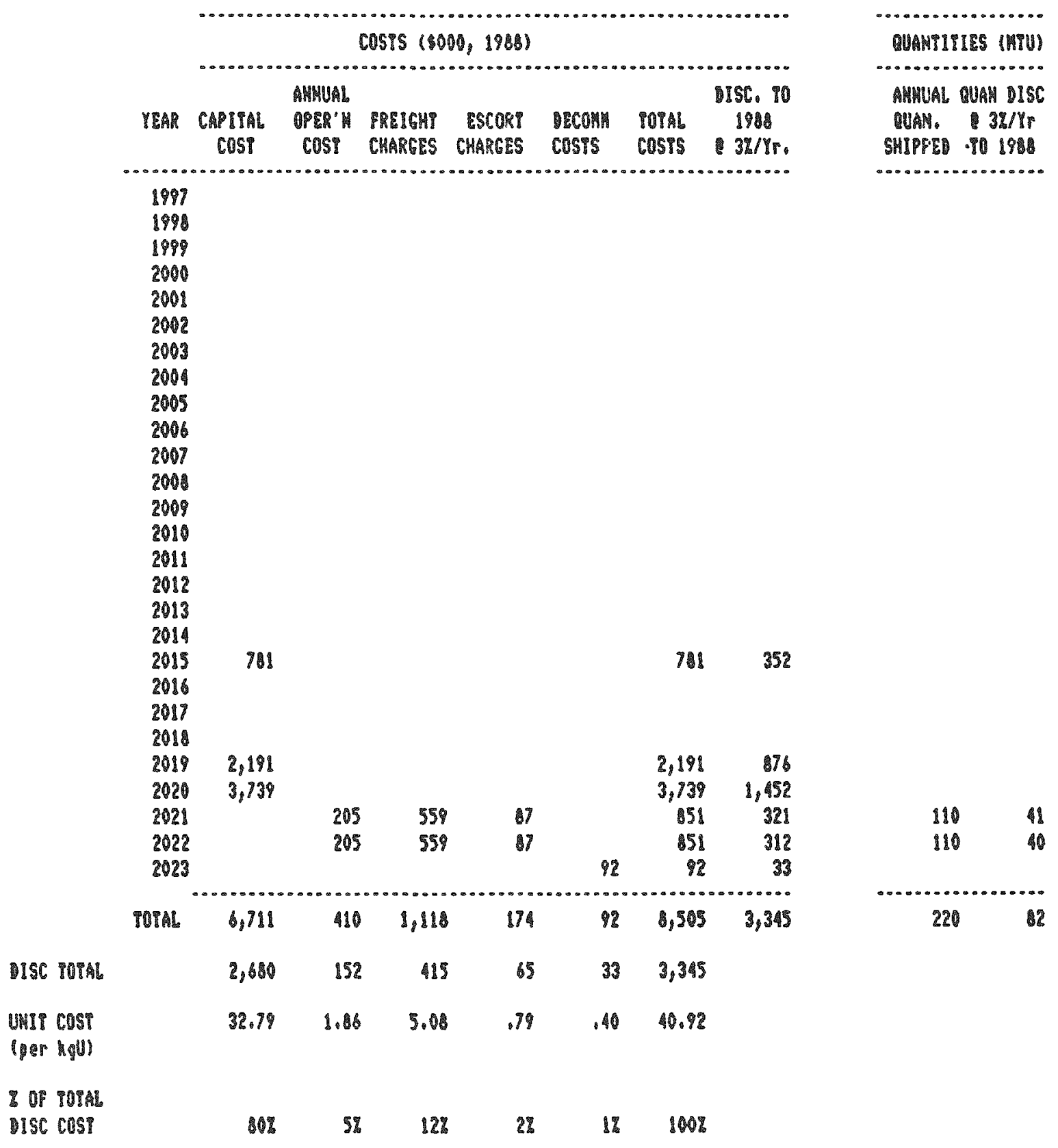


TABLE D-10

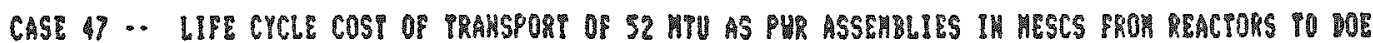
PACULIIIES 2U0O KILES AWAY IN A DEDICATED 2/7 PUR ASSEKBLY MESC SHIPPIMC CASX (OME MESC CASP IN DOE PLEET)

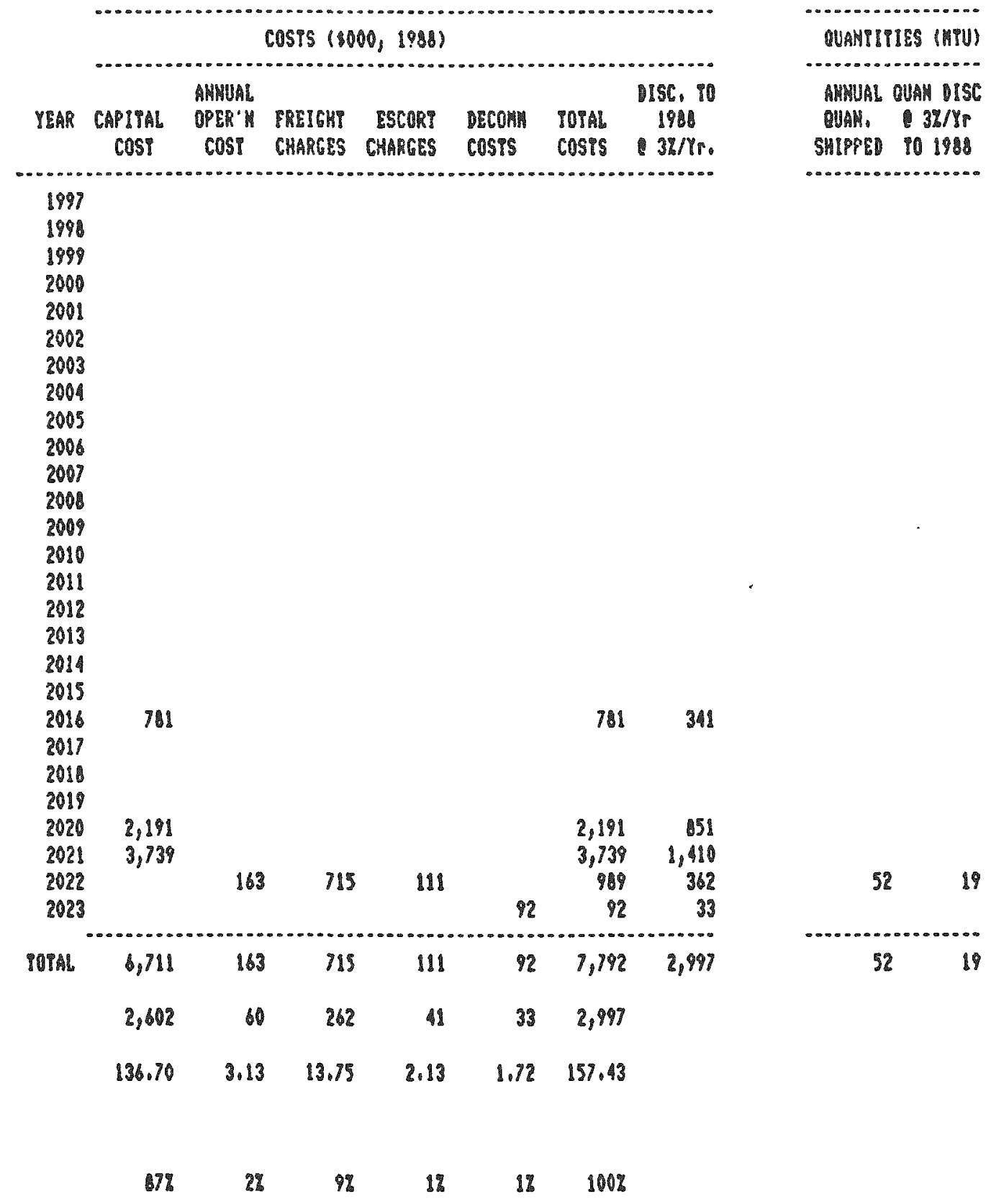


IABLE D. 11

CASE 43 - LIP CYCLE COSP OF IRANSPORT OF 104 HTU AS PHR ASSEHBLIES IN MESCS PROH REACTORS PACILITES 2000 MILES AUAY IN A DEDICATED $2 / 7$ PUR ASSEHBLY MESC SHIPHIHG CASL

(OHE HESC CASY IN DOE FLEET)

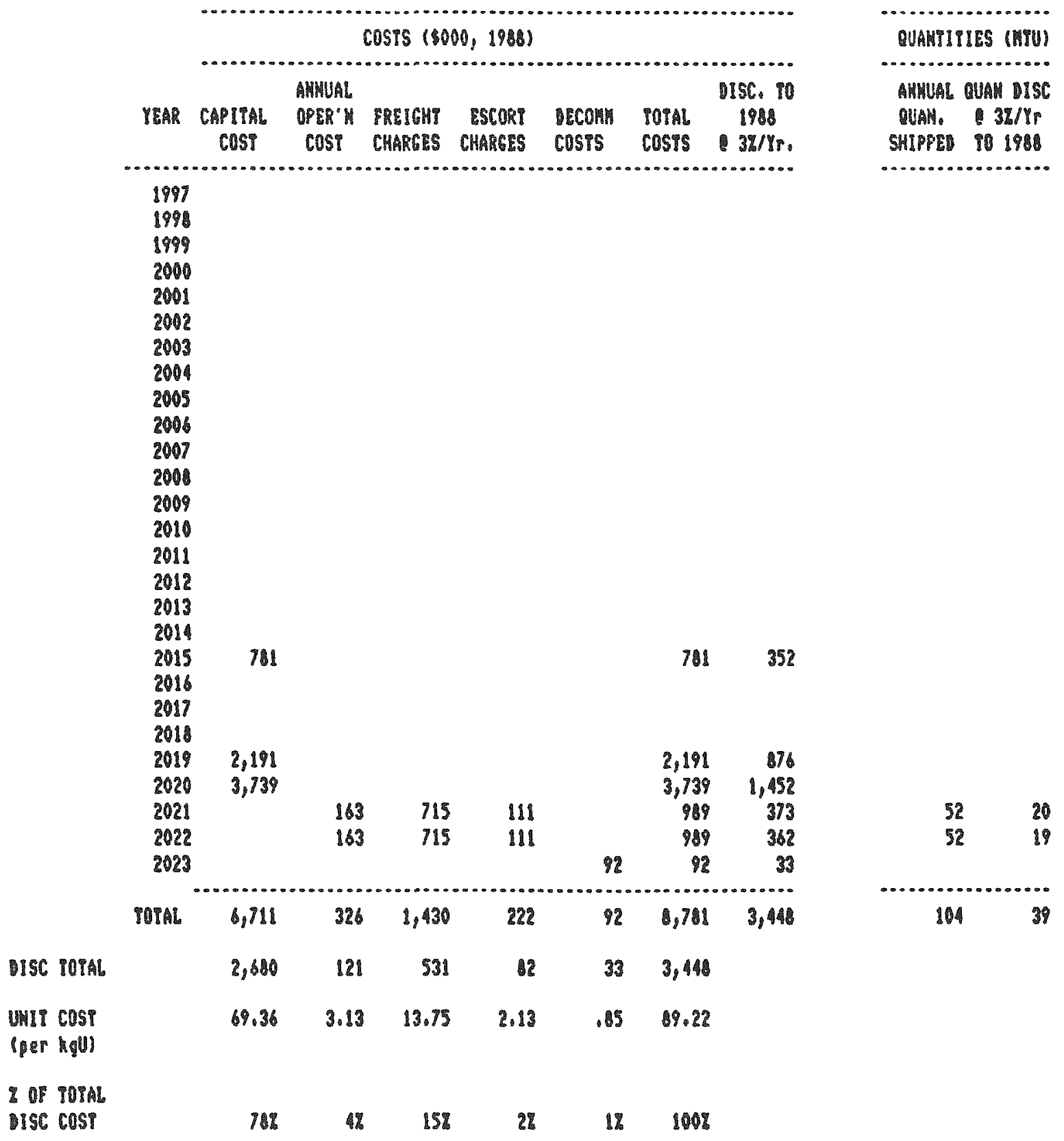


Th: 19

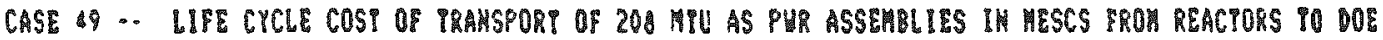
FACIHIIES 2000 MILES AMAY IN A DEDICATED 217 PUR ASSEMHLY KESC SHIPPING CASK

POME MESC CAST II DOE PLECT

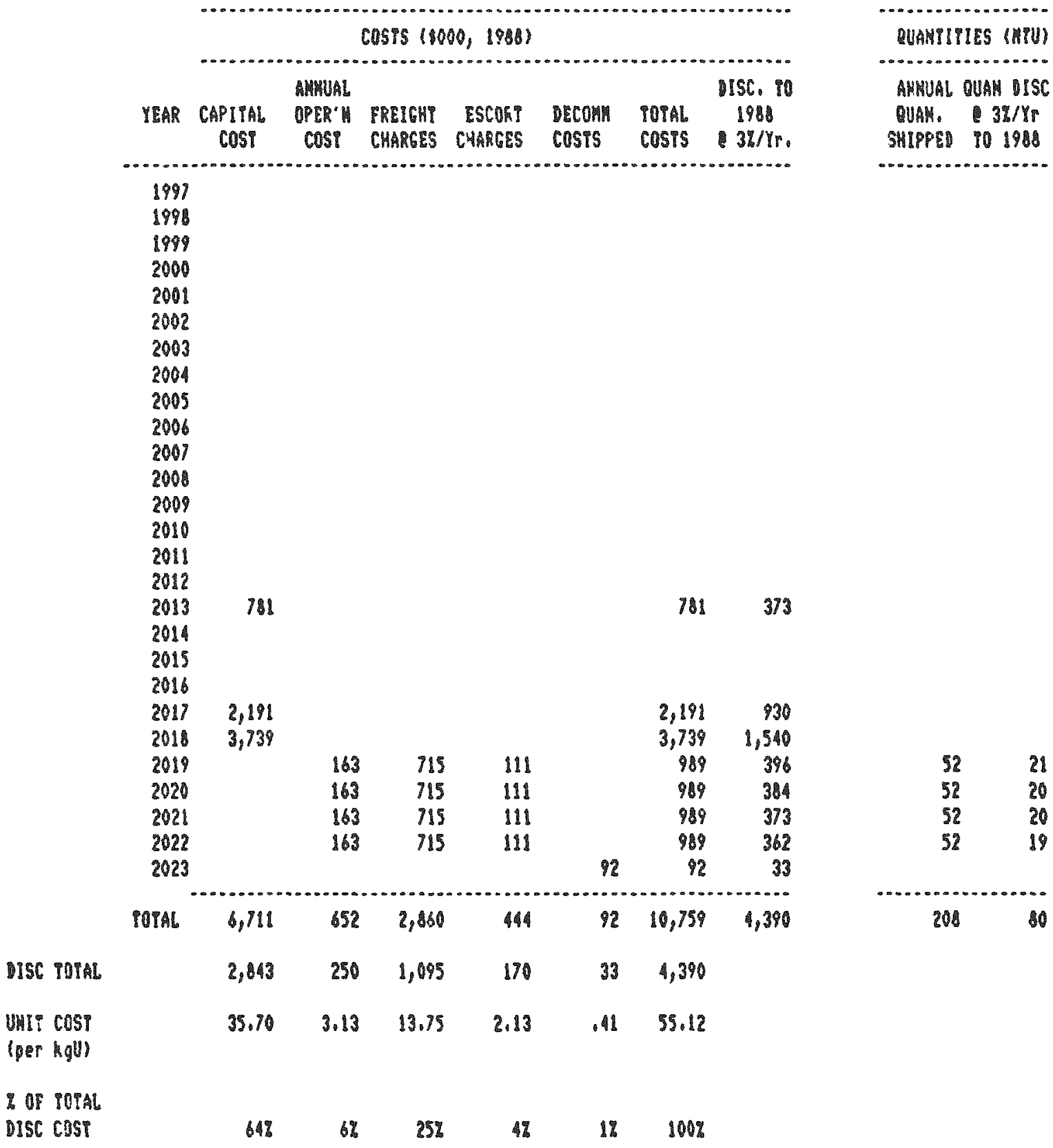


APPENDIX E

INCREMENTAL LIFE CYCLE COSTS AND UNIT COST CALCULATIONS

ASSOCIATED WITH THE PROCESSING OF MESCS IN FWMS FACILITIES 
INCREMENTAL LIFE CYCLE COSTS AND UNIT COST CALCULATIONS ASSOCIATED WITH THE PROCESSING OF MESCS IN FWMS FACILITIES

The total incremental life cycle costs associated with the processing of MESCS in FWMS facilities were developed for the following cases.

\begin{tabular}{|c|c|c|c|c|c|}
\hline \multirow{2}{*}{$\begin{array}{l}\text { Table } \\
\text { No. }\end{array}$} & \multirow{2}{*}{$\begin{array}{l}\text { Type of } \\
\text { MESC } \\
\text { Received }\end{array}$} & \multirow{2}{*}{$\begin{array}{c}\text { MRS } \\
\text { Status }\end{array}$} & \multirow{2}{*}{$\begin{array}{c}\text { Total } \\
\text { Quantity SNF } \\
\text { Received in } \\
\text { MESCs (MTU) }\end{array}$} & \multicolumn{2}{|c|}{ MESC Opening Operation } \\
\hline & & & & Location & Time \\
\hline $\begin{array}{l}E-1 \\
E-2 \\
E-3 \\
E-4\end{array}$ & 24 PWR Assy & With MRS & $\begin{array}{r}564 \\
940 \\
1,504 \\
1,880\end{array}$ & Outside of Hot Cell & Upon Receipt \\
\hline $\begin{array}{l}E-5 \\
E-6 \\
E-7 \\
E-8\end{array}$ & 24 PWR Assy & No MRS & $\begin{array}{r}534 \\
890 \\
1,424 \\
1,780\end{array}$ & Outside of Hot Cell & Upon Receipt \\
\hline $\begin{array}{l}E-9 \\
E-10 \\
\varepsilon-11\end{array}$ & 7 PWR Assy & With MRS & $\begin{array}{l}58 \\
116 \\
232\end{array}$ & Outside of Hot Cell & Upon Receipt \\
\hline $\begin{array}{l}E-12 \\
E-13 \\
E-14\end{array}$ & 7 PUR Assy & No MRS & $\begin{array}{r}52 \\
104 \\
208\end{array}$ & Outside of Hot Cell & Upon Receipt \\
\hline $\begin{array}{l}E-15 \\
E-16 \\
E-17 \\
E-18\end{array}$ & 24 PWR Assy & $\begin{array}{l}\text { With MRS } \\
\text { (Vertical } \\
\text { Concrete } \\
\text { Cask) }\end{array}$ & $\begin{array}{r}564 \\
940 \\
1.504 \\
1.880\end{array}$ & In Hot Cell & After Storage \\
\hline $\begin{array}{l}E-19 \\
E-20 \\
E-21 \\
E-22\end{array}$ & 24 PUR Assy & No MRS & $\begin{array}{r}534 \\
890 \\
1,424 \\
1,780\end{array}$ & In Hot Cell & After Storage \\
\hline $\begin{array}{l}E-23 \\
E-24 \\
E-25\end{array}$ & 7 PWR Assy & $\begin{array}{l}\text { With MRS } \\
\text { (Vertical } \\
\text { Concrete Cask) }\end{array}$ & $\begin{array}{r}58 \\
116 \\
232\end{array}$ & In Hot Cell & After Storage \\
\hline $\begin{array}{l}E-26 \\
E-27 \\
E-28\end{array}$ & 7 PWR Assy & NO MRS & $\begin{array}{r}52 \\
104 \\
208\end{array}$ & In Hot Cell & After Storage \\
\hline $\begin{array}{l}E-29 \\
E-30 \\
E-31 \\
E-32\end{array}$ & 24 PUR Assy & With MRS (HSM) & $\begin{array}{r}564 \\
940 \\
1,504 \\
1,880\end{array}$ & In Hot Cell & After storage \\
\hline $\begin{array}{l}E-33 \\
E-34 \\
E-35\end{array}$ & 7 PUR ASSY & With MRS (HSM) & $\begin{array}{r}58 \\
116 \\
232\end{array}$ & In Hot Cell & After Storage \\
\hline $\begin{array}{l}E-36 \\
E-37 \\
E-38 \\
E-39\end{array}$ & 24 PWR AsSy & With WRS (HSM) & $\begin{array}{r}563 \\
940 \\
1,504 \\
1,880\end{array}$ & Outside of hot Cell & After storage \\
\hline $\begin{array}{l}E-40 \\
E-41 \\
E-42\end{array}$ & 7 PWR ASSY & With MRS (HSM) & $\begin{array}{r}58 \\
116 \\
232\end{array}$ & Outside of Hot Cell & After Storage \\
\hline
\end{tabular}

AMESCs are stored in vertical concrete casks or horizontal storage modules (HSM). 
The quantities used in the cases described above were the same as those used in developing the life cycle transportation costs for MESC shipping casks in Appendices $A$ through $D$ inasmuch as they represented representative amounts of SNF that might be delivered to FWMS facilities in MESCs using a reasonable transportation strategy.

The incremental life cycle costs and resulting incremental unit costs for each of the foregoing cases were developed as follows:

(1) For cases where the MESCs are opened outside of hot cell facilities, the cost of the MESC opening equipment was assumed to be shared between the 24 PWR assembly MESCs $180 \%$ of the cost) and 7 PWR assembly MESCs (20\% of the cost). This split also was applied to the cost of disposal. This division of costs was based on the assumptions that 10 percent of the cost of the equipment was due to special features that were incorporated in order to be able to handle the 7 PWR assembly MESCs, and that the quantity of fuel received in 7 PWR assembly MESCs would represent 10 percent of the total SNF received in MESCS.

(a) For cases where the MESCs are opened upon receipt, it was assumed that the cost of the equipment would be incurred in the year immediately prior to the first receipt of 24 PWR assembly MESCs; with the pro rata portion of the cost allocated to 7 PWR assemb7y MESCs being incurred in the year immediately prior to the first receipt of 24 PWR assembly MESCs for cases where the total amount of SNF received therein was about 10 times the total quantity received in 7 PWR assembly MESCs. The pro rata share of disposal costs was assumed to be incurred in 2023.

(b) For cases where the MESCs are opened after storage at the MRS facility, it was assumed that the cost of the equipment would be incurred in 2026. The pro rata share of the disposal costs was assumed to be incurred in 2028 .

(2) For cases where the MESCs are opened inside the hot cell facilities, the cost of the additional hot cell facilities and equipment was assumed to be shared between the 24 PWR assembly MESCs (90\% of the cost) and 7 PWR assembly MESCs (10\% of the cost). This split was also applied to the cost of decommissioning. This division of cost was based on the assumption that 10 percent of the SNF in MESCs would be received in 7 PWR assembly MESCs and the remainder would be received in 24 PWR assembly MESCS. Moreover, it was assumed that the cost of the hot cells would be incurred during the period 1998 through 2002, and that the costs would be equally distributed during that period. The pro rata share of the decomissioning costs was assumed to be incurred in 2033, 30 years after the startup of the hot cell facilities. 
(3) For cases where MESCs are stored in vertical concrete storage casks in MRS facilities, the costs of additional concrete pads were determined using the formulas described in section 4.3.2.7. It was assumed that the costs of these casks and HSMs were incurred in the year they were first used for storage.

(4) For cases where MESCs are opened inside the hot cell facilities, the fixed operating costs were assumed to be shared between the 24 PWR assembly MESCs (90\% of the cost) and 7 PWR assembly MESCs (10\% of the cost), on the assumption that 10 percent of the SNF in MESCs would be received in 7 PWR assembly MESCs and the remainder would be received in 24 PWR assembly MESCs. It was assumed that these costs would be incurred from the time the construction of the hot cell facility was completed until it was decommissioned. Further, it was assumed that a11 MESCs in storage at a MRS facility would be removed therefrom in 2027 and opened then; the unit costs developed in Section 4.2.3.5 were applied against the total quantity of SNF contained in MESCs in storage at the MRS facility. However, the cost of opening the MESCs was assumed to be incurred as they were received when there was no MRS facility in the FWMS.

(5) For cases involving storage in a MRS facility, the additional storage area operating costs were assumed to be incurred in both the years of emplacement and the years of removal, except where the MESCs are stored in HSMS where the costs are incurred only in the year of removal.

(6) MESC disposal costs were assumed to be incurred in the year the MESCs are opened and the contained SNF unloaded therefrom.

(7) MRS cask/HSM and concrete pad decommissioning or disposal costs would be incurred in the year after removal of the MESCs therefrom (2028).

(8) For cases where MESCs are stored in HSMS, the cost of HSM loading equipment was assumed to be shared between the 24 PWR assembiy MESCs (90\% of the cost) and 7 PWR assembly MESCs (10\% of the cost), on the assumption that 10 percent of the SNF in MESCs would be received in 7 PWR assembly MESCs and the remainder would be received in 24 PWR assembly MESCs. This split was also applied to disposal costs of the equipment. Moreover, it was assumed that the cost of the equipment would be incurred in the year immediately prior to the first receipt of 24 PWR assembly MESCs; with the pro rata portion of the cost allocated to 7 PWR assembly MESCs being incurred in the year immediately prior to the first receipt of 24 PWR assembly MESCS for cases where the total amount of SNF received there in was about 10 times the total quantity received in 7 PWR assembly MESCs. The pro rata share of disposal costs was assumed to be incurred in 2028 . 
(9) For cases where HSMs are used for MESC storage, it was assumed that the cost of the transfer cask would be incurred in the year immediately preceding the removal of SNF from storage (2026). It was further assumed that the cost of disposal of the cask would be incurred in 2028. Separate transfer casks were assumed to be required for 24 PWR assembly MESCs and 7 PWR assembly MESCs.

(10) The costs used to develop the incremental life cycle costs are summarized below (1988 dollars):

Variable Costs

$(\$ / \mathrm{kgU})^{*}$

Operating Costs for Opening MESCs Outside Hot Cell

24 PWR Assembly MESCs

7 PWR Assembly MESCs

$\$ 0.33$

0.86

MESC Disposal

24 PWR Assembly MESCS

7 PWR Assembly MESCs

Variable Cost of Operation of Hot Cell

24 PWR Assembly MESCs

7 PWR Assembly MESCs

0.21

0.67

MRS Concrete Casks

24 PWR Assembly MESCs HSM

7 PWR Assembly MESCs

24 PWR Assembly MESCs

7 PWR Assembly MESCs

Storage Area Operating Costs (For either loading or unloading)

24 PWR Assembiy MESCs

7 PWR Assembly MESCS

0.04

ÆFigures in parentheses denote savings

Fixed Costs

$(\$ 000)$

Equipment for Opening MESCs Outside Hot Cell

$\$ 499$

Hot Cell Additions

Fixed Annual Operating Costs of Hot Cell

5,720

HSM Loading Equipment

194

760

Transfer Cask

Storage Pads for 24 PWR Assembly MESC Casks

1,000

564 MTU

104

940 MTU

163

1,504 MTU

252

1,880 MTU

310

Storage Pads for 7 PWR Assembly MESC Casks 58 MTU

116 MTU

232 MTU 
(11) The total costs were discounted by $3 \% /$ year to 1988 to get the total discounted costs.

(12) The unit costs were determined by dividing the total discounted costs by the total discounted amount (MTU) of SNF received in MESCS, as follows:

Discounted Costs $=$ Discounted (Unit Costs $\times$ MTU Received)

Discounted Costs - Unit Costs $\times$ Discounted MTU Received

Unit cost $=\frac{\text { Discounted Costs }}{\text { Discounted MTU Received }}$

A more detailed explanation of the methodology used for the unit cost calculation is set forth in Appendix $F$. 
TABLE E-1

IMCREMEUTAL UPE CYCLE COST OF PUMS PACILIIIES RESULPIHG PRON RECEIPT OF SW HTV AS PUR ASSEMILIES IN 24 PUR ASSEMILY MESCS AP MRS PACILITY

IHESCS OPEHED OUTSIDE OF MOT C:LL EACILITIES UPON ARCEIPI

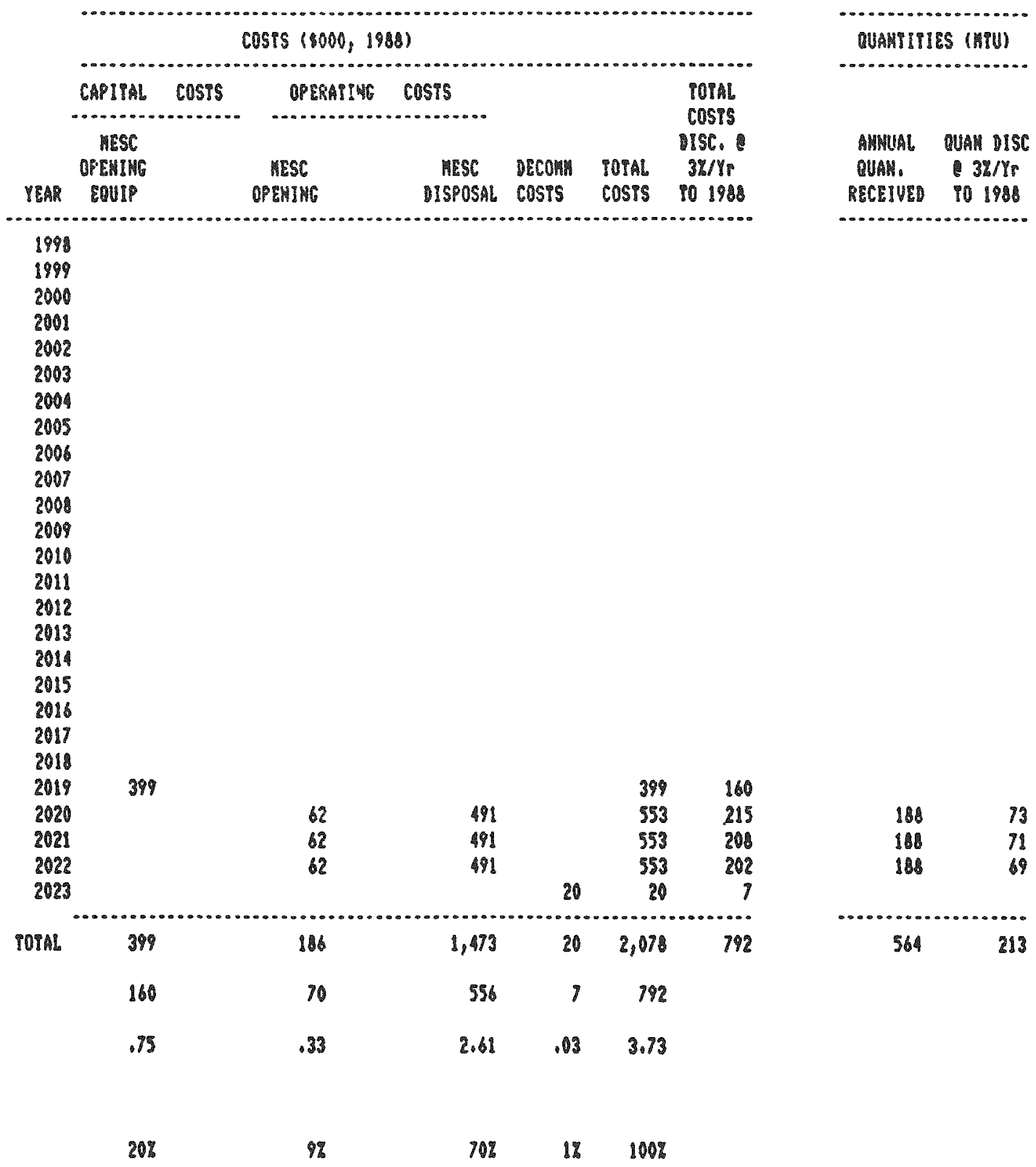


PABLE E-2

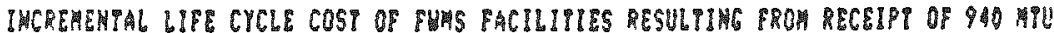
AS PUR ASSEMBLIES IN 24 PUR ASSEERLY MESCS AT MRS FACILITY IHESCS OPEHED OUTSIDE OF HOT CELL FACILITIES UPOH RECEIPT)

COSTS $(1000,1980)$

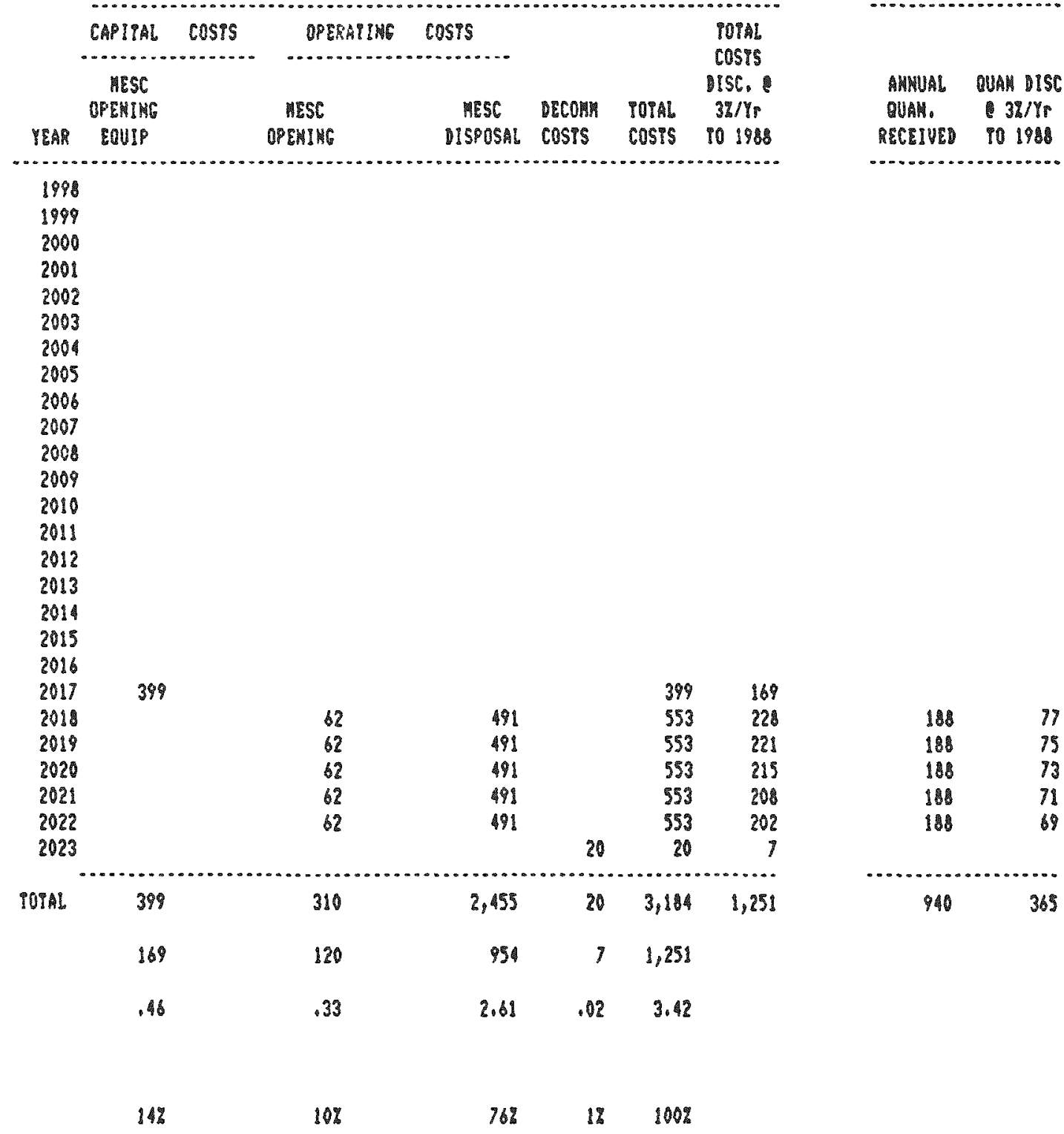


PADLE E-3

INCREMEMTAL UIFE CYCLE COSI OP PUTS FACILITIES RESULTIMG PROA RECEIPI OF ISOA HTU AS PUR ASSEMBLIES IM 24 PUR ASSEHALY MESCS AT MRS FACILITY

IMESCS OPENED OUPSIDE OP HOT CELL FACILITIES UPON RECEIPT)

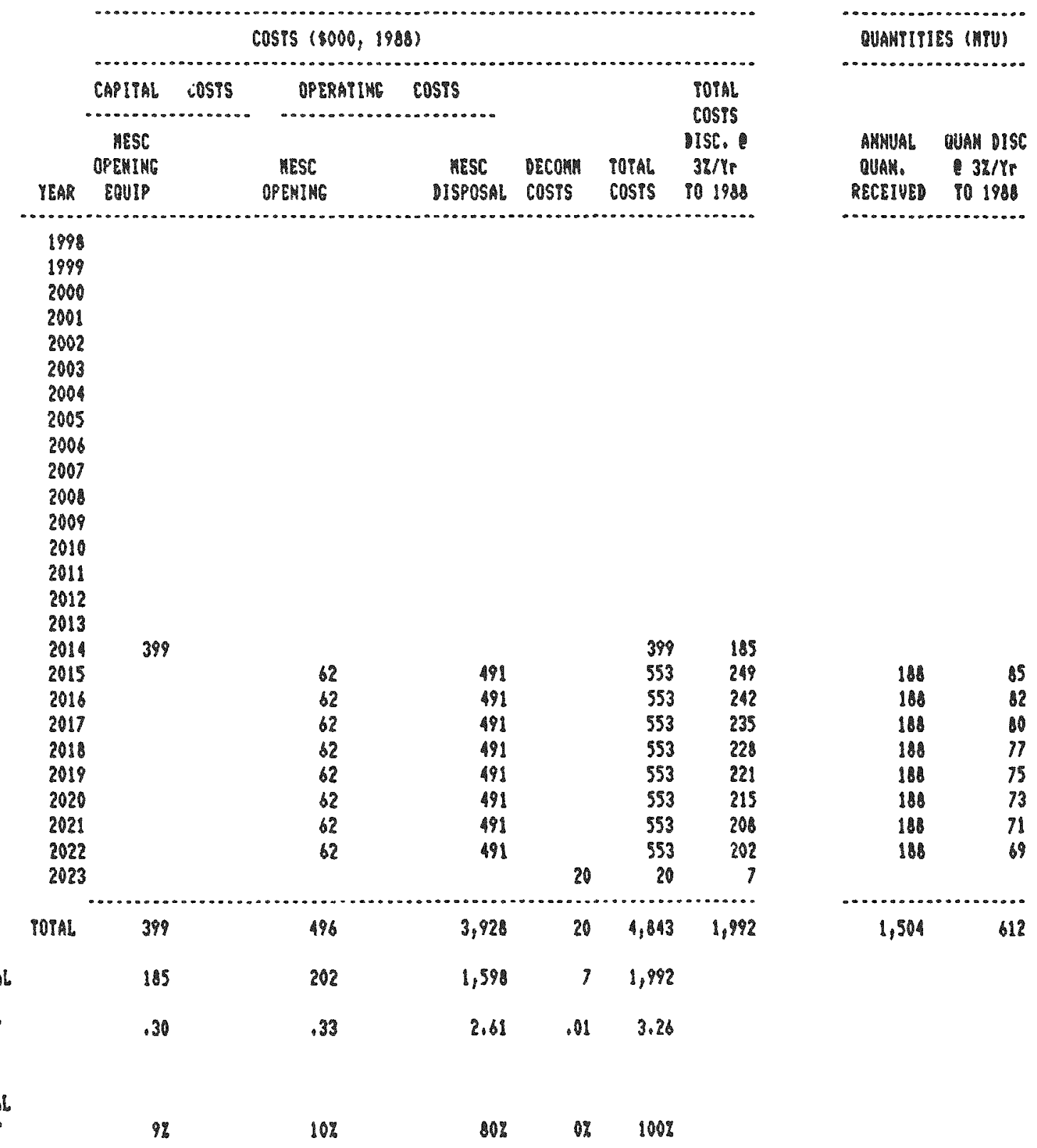


TABLE E-4

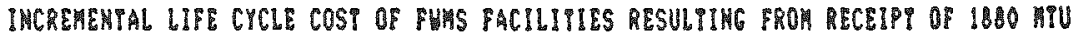
AS PHR ASSEKLLIES IN 24 PUR ASSEMULY HESCS AP HRS PACILITY (MESCS OPEMED OUTSIDE OF HOI CELL PACIUIP'SS UPOH RECEIPT)

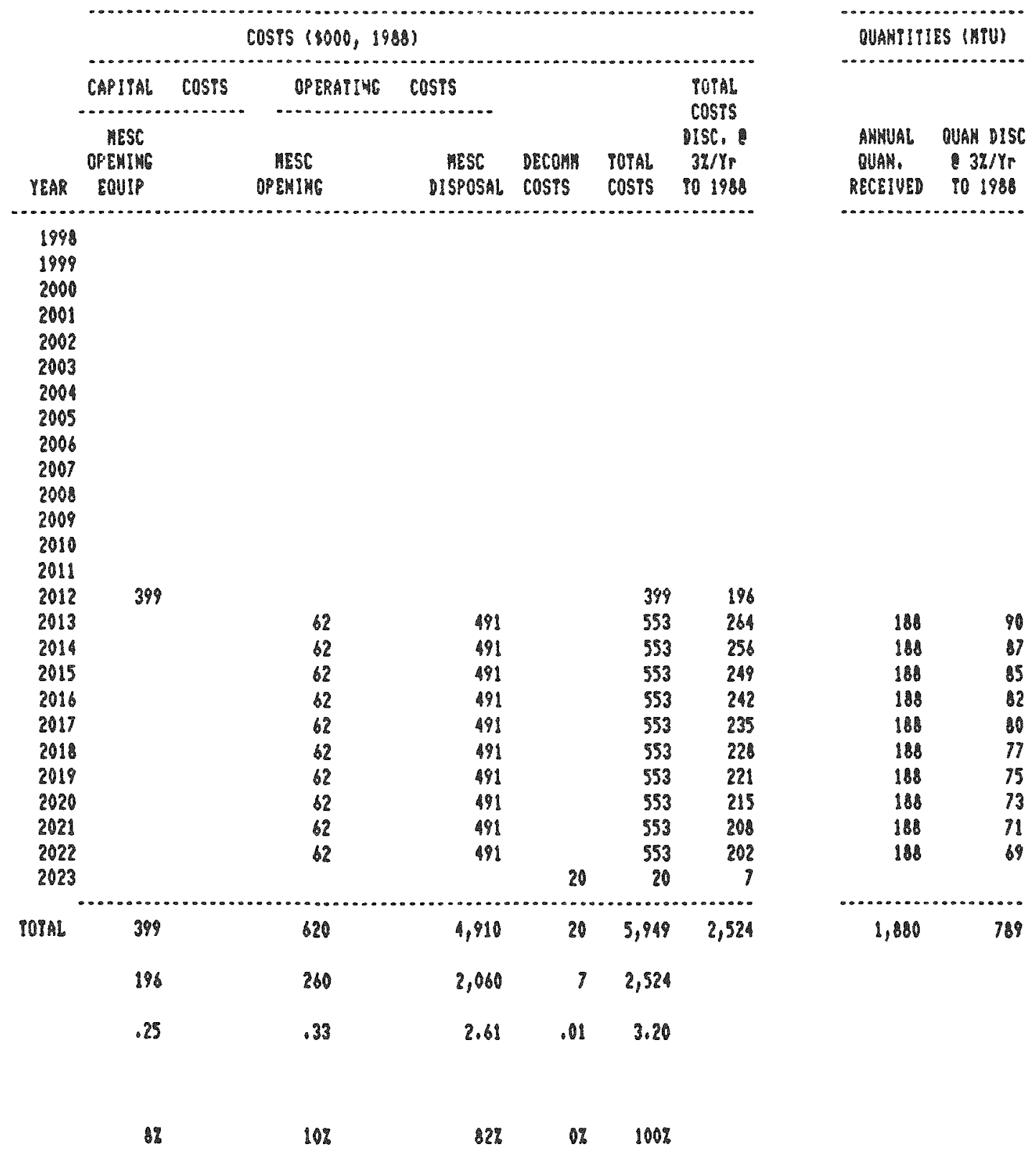


PABLE E-5

IUCREAEHPAL UIF CYCLE COSP OF PUMS FACILIIIES RESULTIUG PRO RECEIP OF 534 MTU AS PUR ASSEMBLIES IN 24 PUR ASSEABLY HESCS AT REPOSITORY

(HESCS OPENED OUPSIDE OF HO CELL PACIIITIES UPOM RECEIPT)

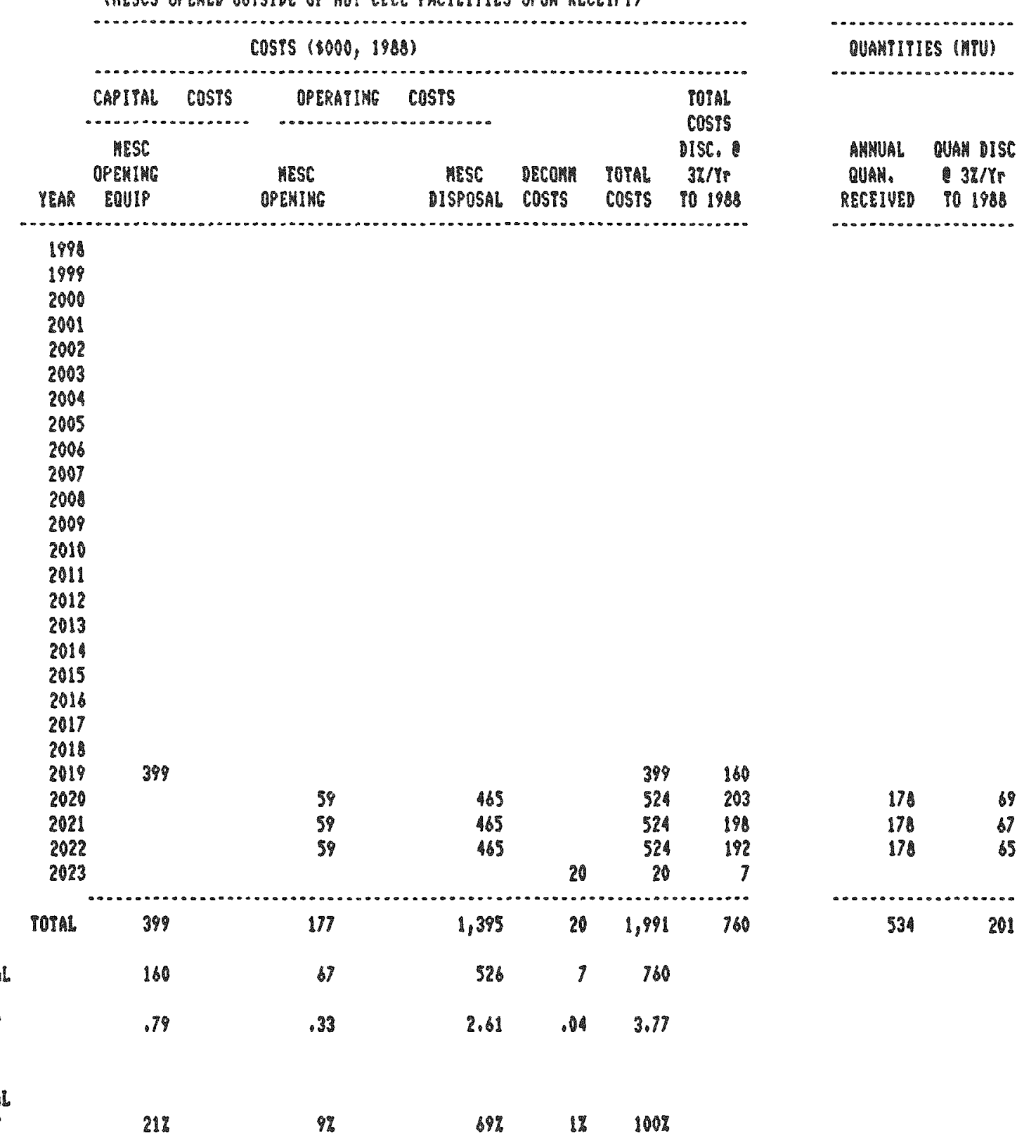

DISC IOTAL

UHIT $\cos$ I

ferer kgul

DOF TOTAL

DISE COSP

$21 \%$

9

$69 \%-1 \% \quad 100 \%$ 


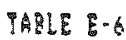

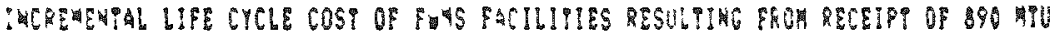

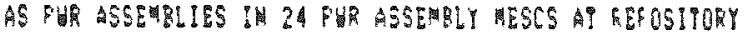

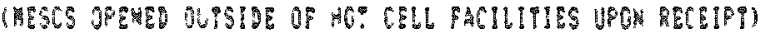

cosis (\$0:0.1989)

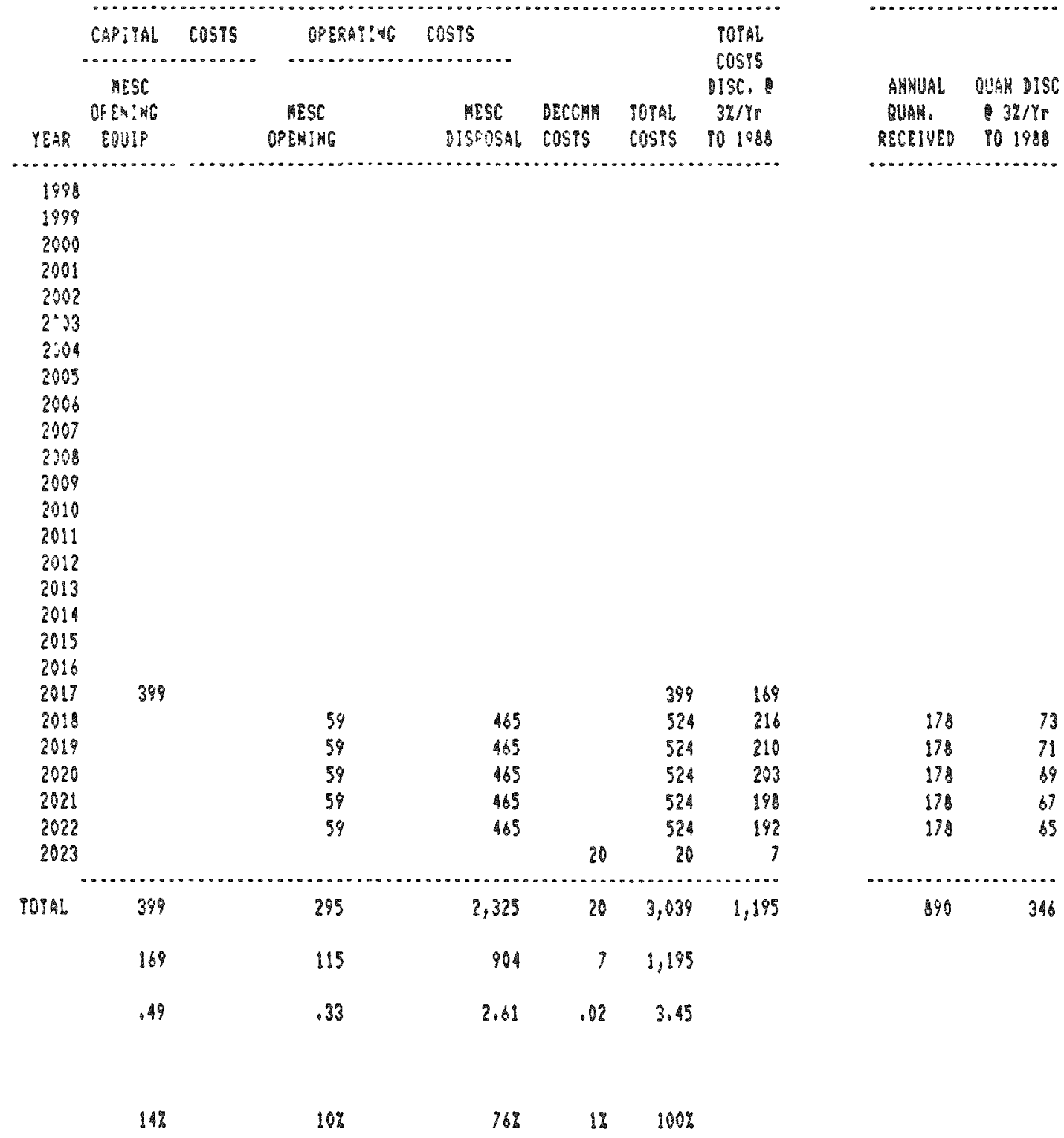


PALLE R-7

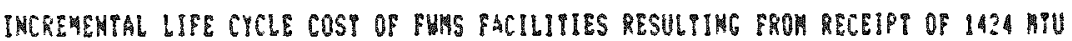
AS PUR ASSEMBLIES IN 24 PUR ASSEMBLY MESCS AI REPOSITORY (HESCS OFERED OUTSIDE OF HOT CELL FACIHIIIES UPOH RECEIFT)

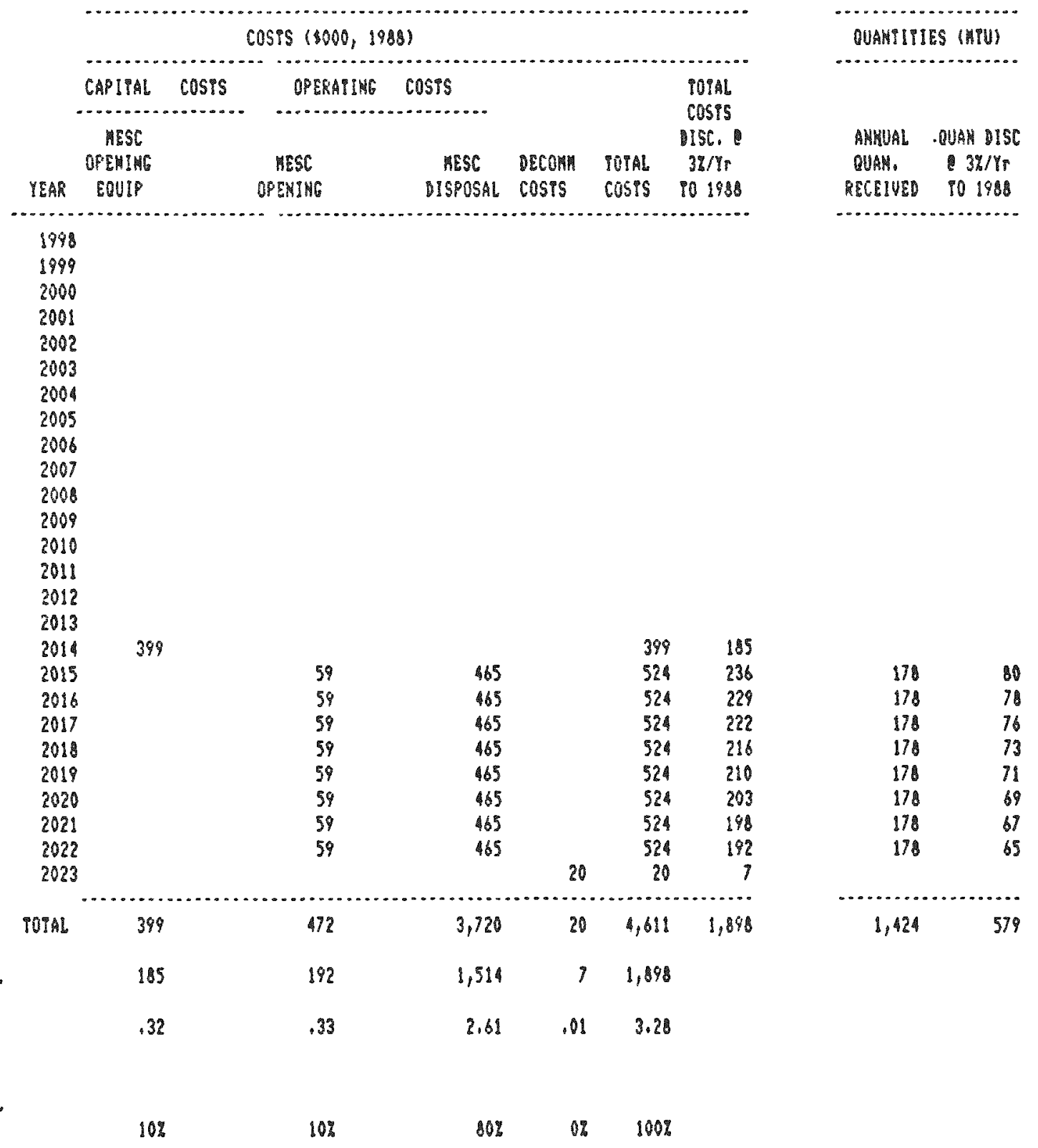


TARLE E-8

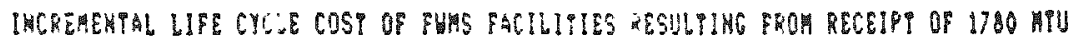

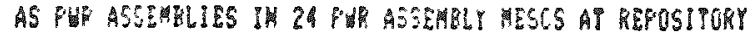

(HESCS OFEMD OUPSIDE OP HOP CELL PACHITIES UPOH RECEIPI)

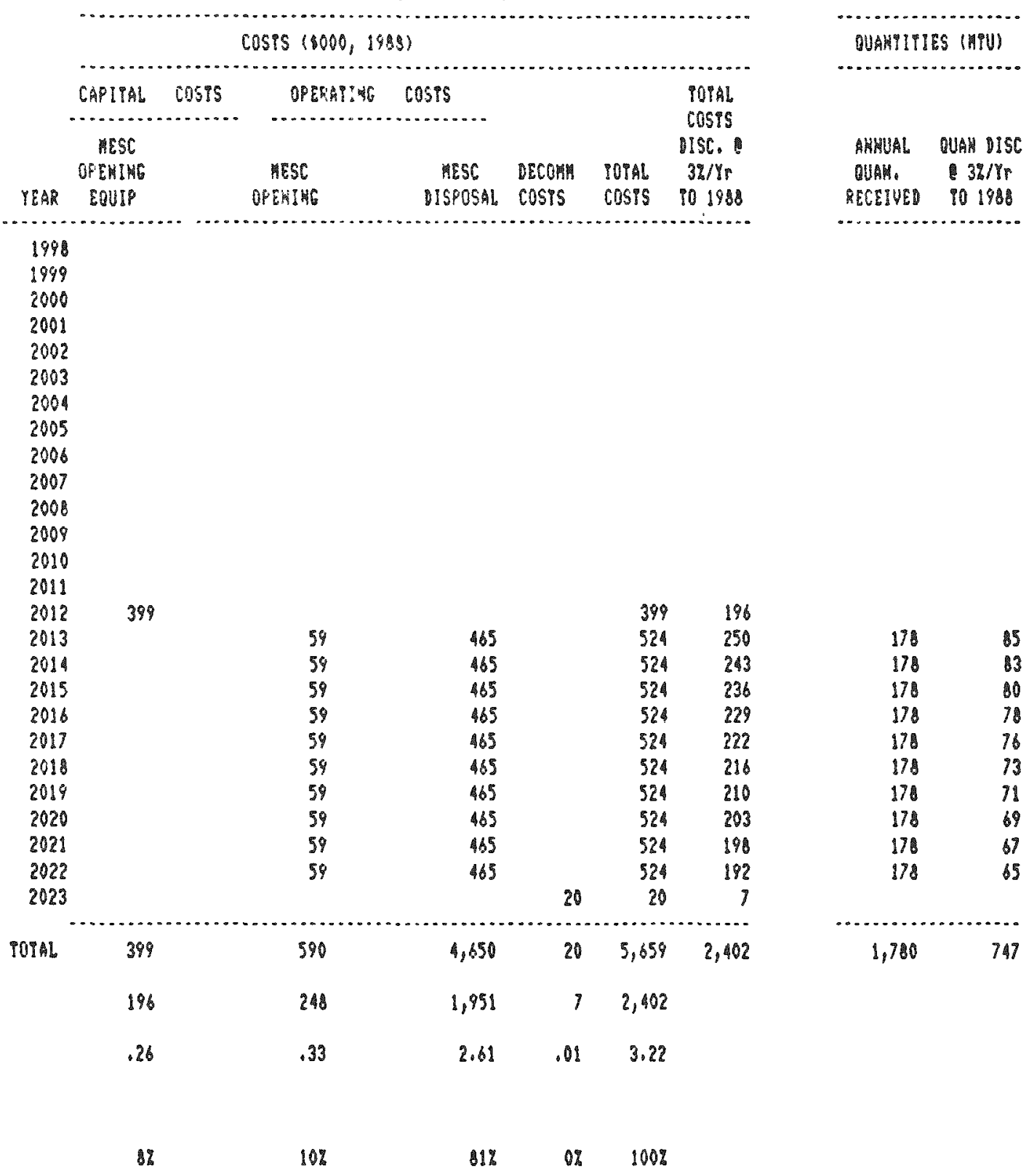


PADLE S-9

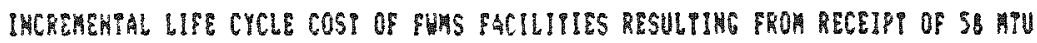
AS PUP ASEEAULLS IH 7 PUR ASEE

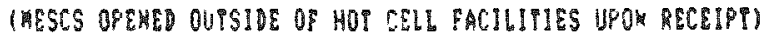

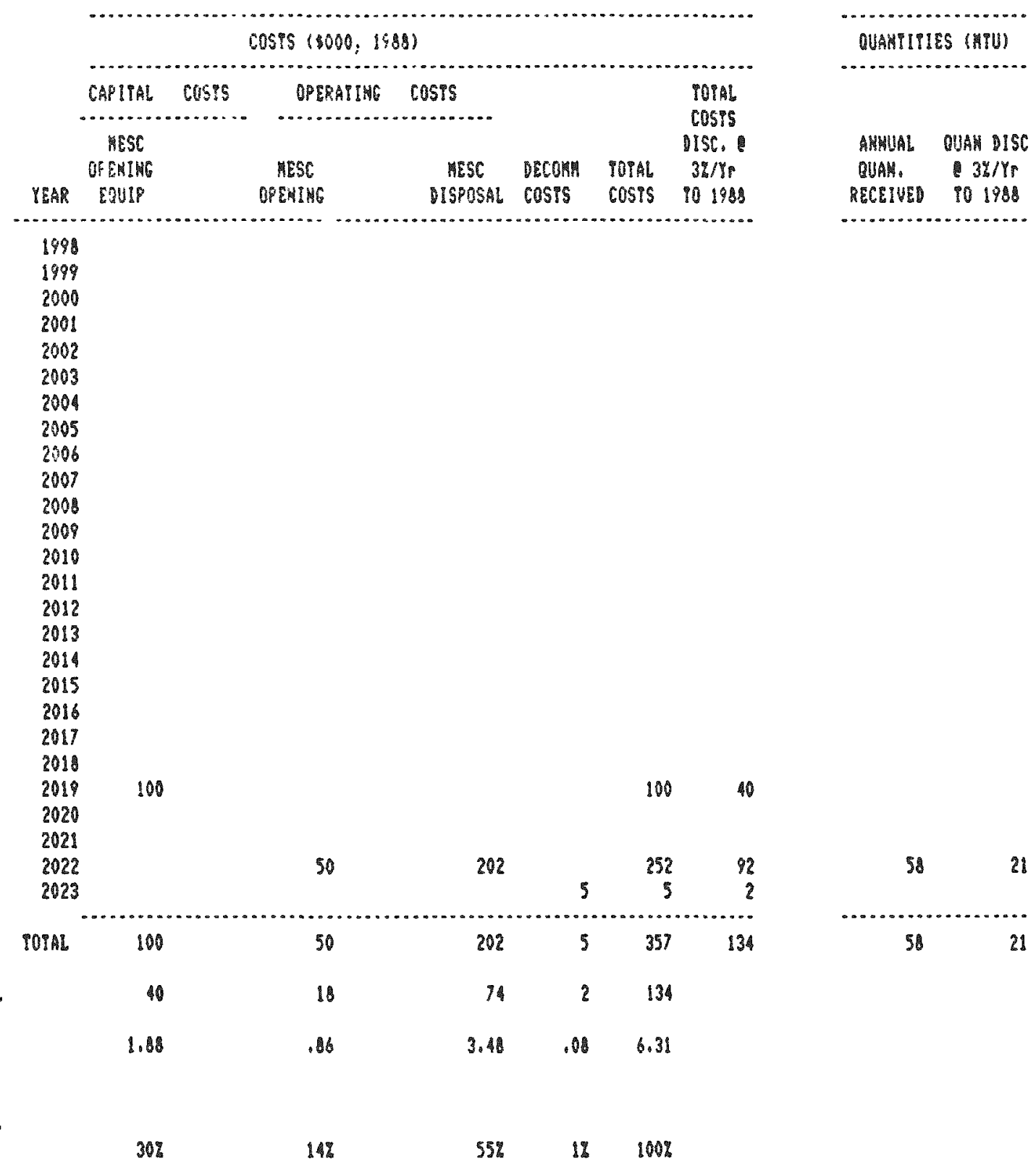


PAR!E $8-: 0$

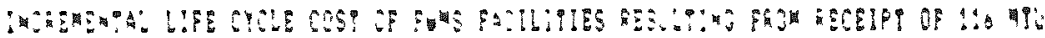
AS P.

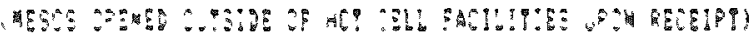

$$
\text { Cosis inger } 1989
$$

\begin{tabular}{|c|c|c|c|c|c|c|}
\hline CAOPAL & cosis & 1P:A:" & cusis & & & 109AL \\
\hline & & & $\ldots \ldots \ldots$ & & & $\cos 9$ \\
\hline IES & & & & & & BSC. \\
\hline Q:5. & & Mesc & ตE⿱ & 05654 & POTAL & $3 \% / Y F$ \\
\hline 82.75 & & OF: प: & 1.3P0SAL & Môs & cosis & 901588 \\
\hline
\end{tabular}

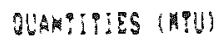

……

ANWIAL OUS BISC

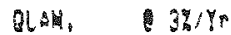
RECEIVED PO I9BS

\begin{tabular}{|c|c|c|c|c|c|c|c|c|}
\hline$Y E^{\prime A R}$ & $82.7^{\circ}$ & Or: & D.5POSAL & 03515 & cosis & 901588 & SECEIVED & 101985 \\
\hline 1098 & & & & & & & & \\
\hline$\therefore 3$ & & & & & & & & \\
\hline 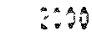 & & & & & & & & \\
\hline 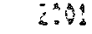 & & & & & & & & \\
\hline 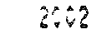 & & & & & & & & \\
\hline $26: 3$ & & & & & & & & \\
\hline $2 \times 4$ & & & & & & & & \\
\hline 2005 & & & & & & & & \\
\hline 2026 & & & & & & & & \\
\hline $200^{\circ}$ & & & & & & & & \\
\hline $28 \%$ & & & & & & & & \\
\hline 2099 & & & & & & & & \\
\hline 2018 & & & & & & & & \\
\hline 2011 & & & & & & & & \\
\hline 6012 & & & & & & & & \\
\hline 2013 & & & & & & & & \\
\hline 2014 & & & & & & & & \\
\hline 2015 & & & & & & & & \\
\hline 2016 & & & & & & & & \\
\hline 2017 & 1000 & & & & 109 & 42 & & \\
\hline 2018 & & & & & & & & \\
\hline 2919 & & & & & & & & \\
\hline 2020 & & & & & & & & \\
\hline 2621 & & 50 & 202 & & 252 & 85 & 58 & 22 \\
\hline 2022 & & 50 & 202 & & 252 & 92 & 58 & 21 \\
\hline 2023 & & & & 5 & 5 & 2 & & \\
\hline IUTAL & 100 & 100 & 404 & 5 & 009 & 231 & 116 & 43 \\
\hline & 42 & 37 & 150 & 2 & 231 & & & \\
\hline & .81 & .85 & 3.48 & .014 & 5.37 & & & \\
\hline & $18 \%$ & $16 \%$ & 65 & $1 \%$ & $100 \%$ & & & \\
\hline
\end{tabular}

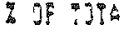

DISE COSI 
PABLE $\mathrm{B}-11$

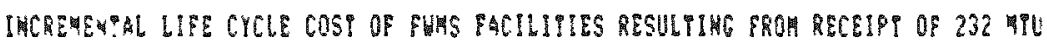
AS PUR ASSEMLIES IW 7 PUT ASSEABLY TESCS AP ARS FACILIIY (AESTS OFENED OUPSIDE OF WOT EELL FACILITES UPON RECEIPT)

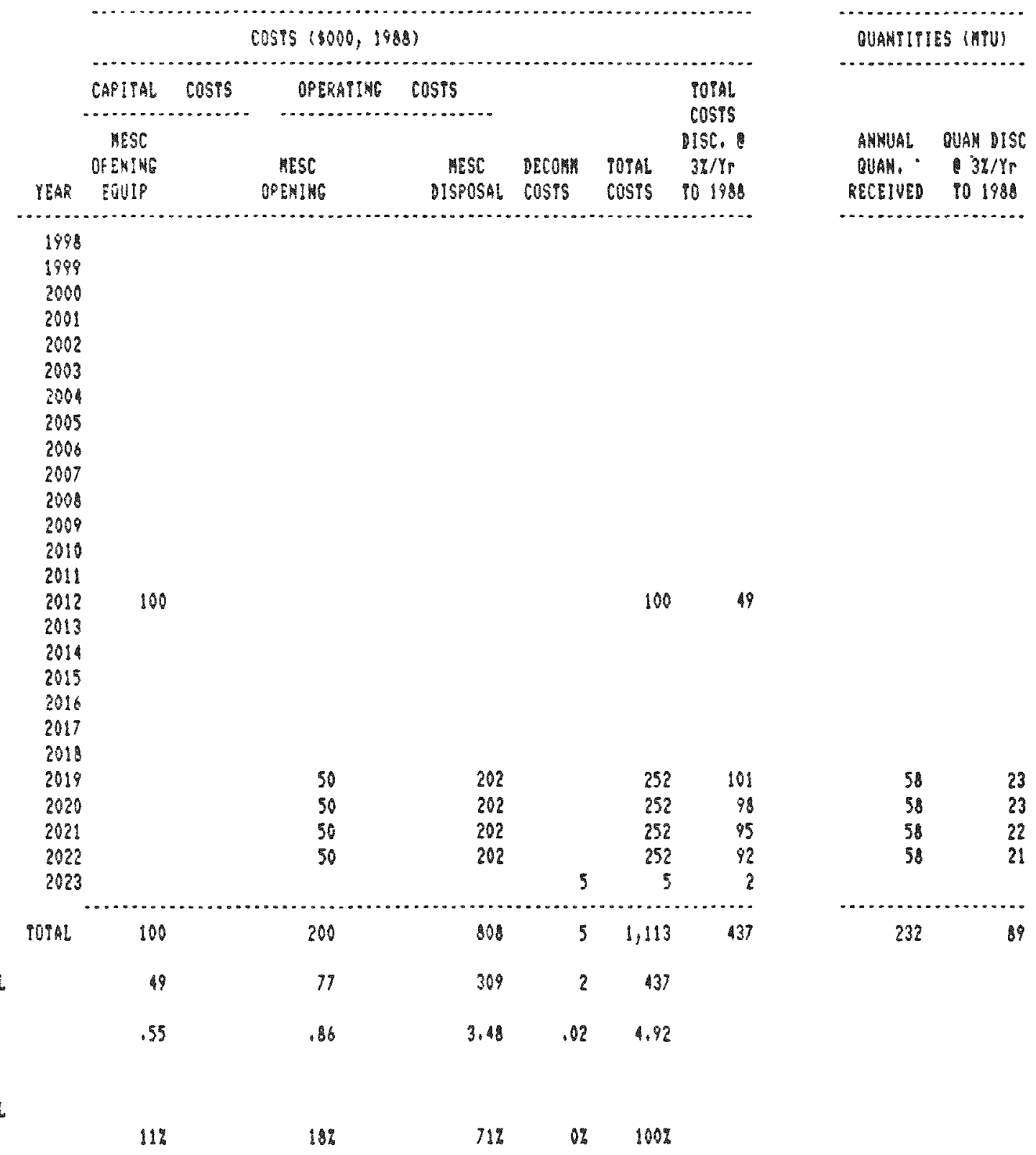


:ABᄂE $E-12$

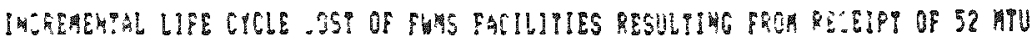

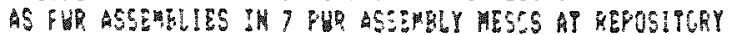

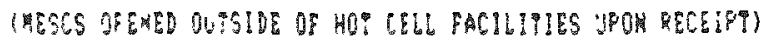

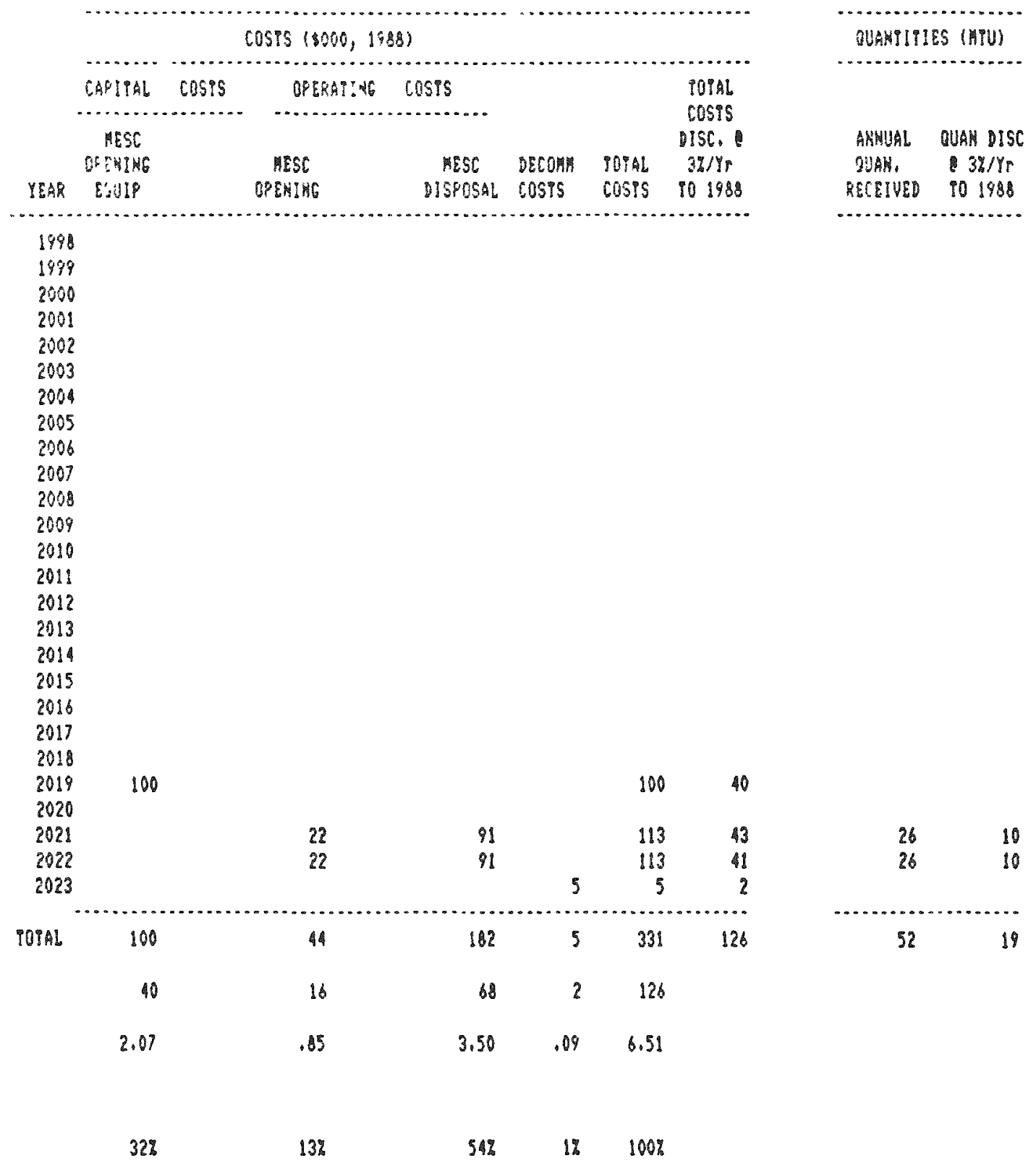

UISE COSP

DISC TOThL

UHII COST

(per kgu)

\% OP TOTAL

322

$13 \%$

$5421 \%$ 
FRRLE E-13

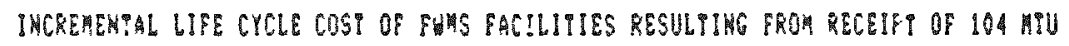

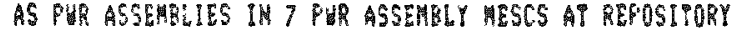

MESCS OPEKE OUPSIDE OF HO: CELL FACIUTIES UPOW RECEIPT)

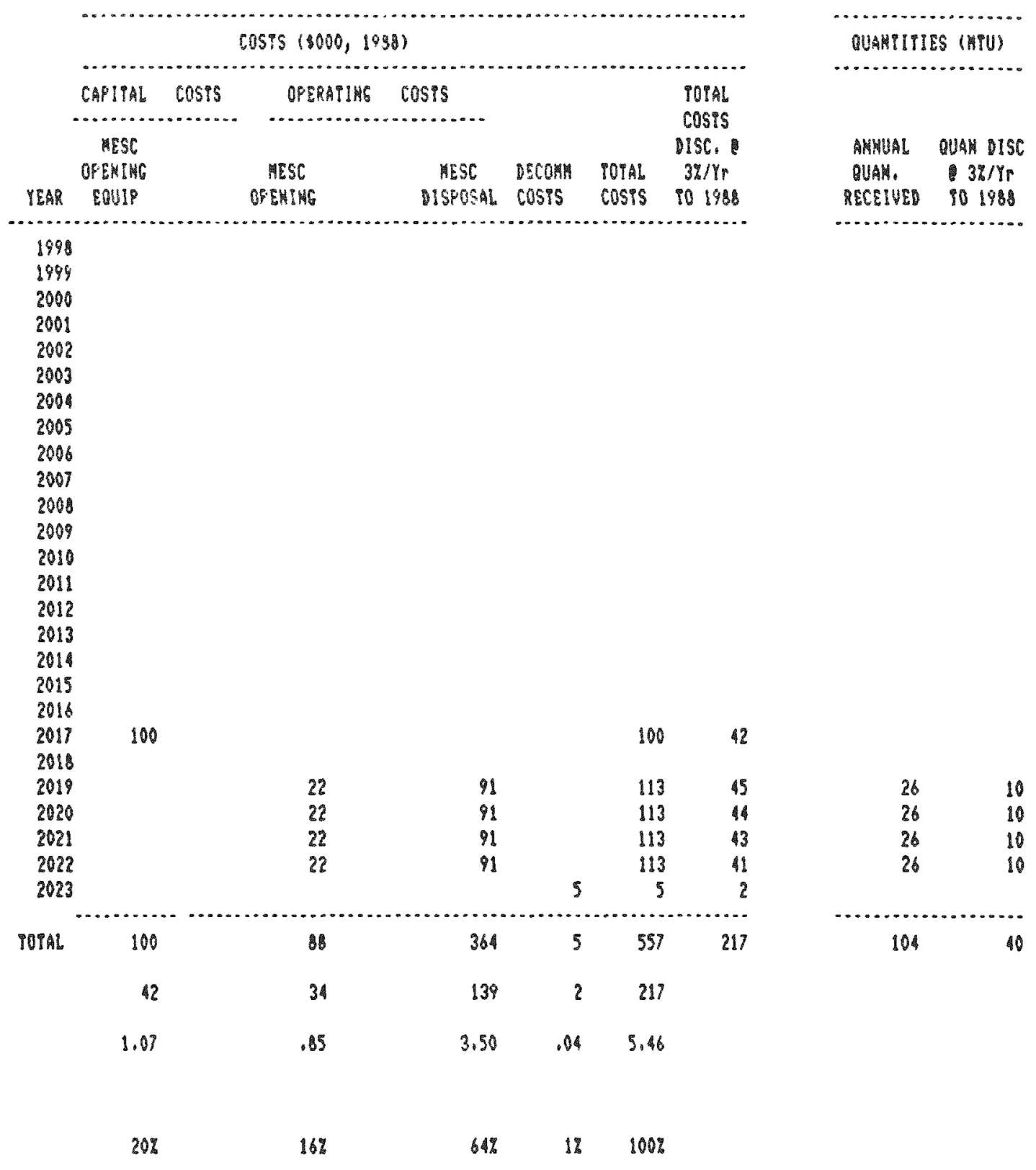

DISE TOTAL

UMIT COST

(per hgu)

2 OS TUTAL

ISC COST

$20 \%$ 
TAELS E-14

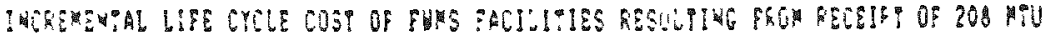
AS FUR ASE:

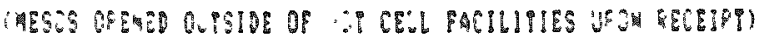

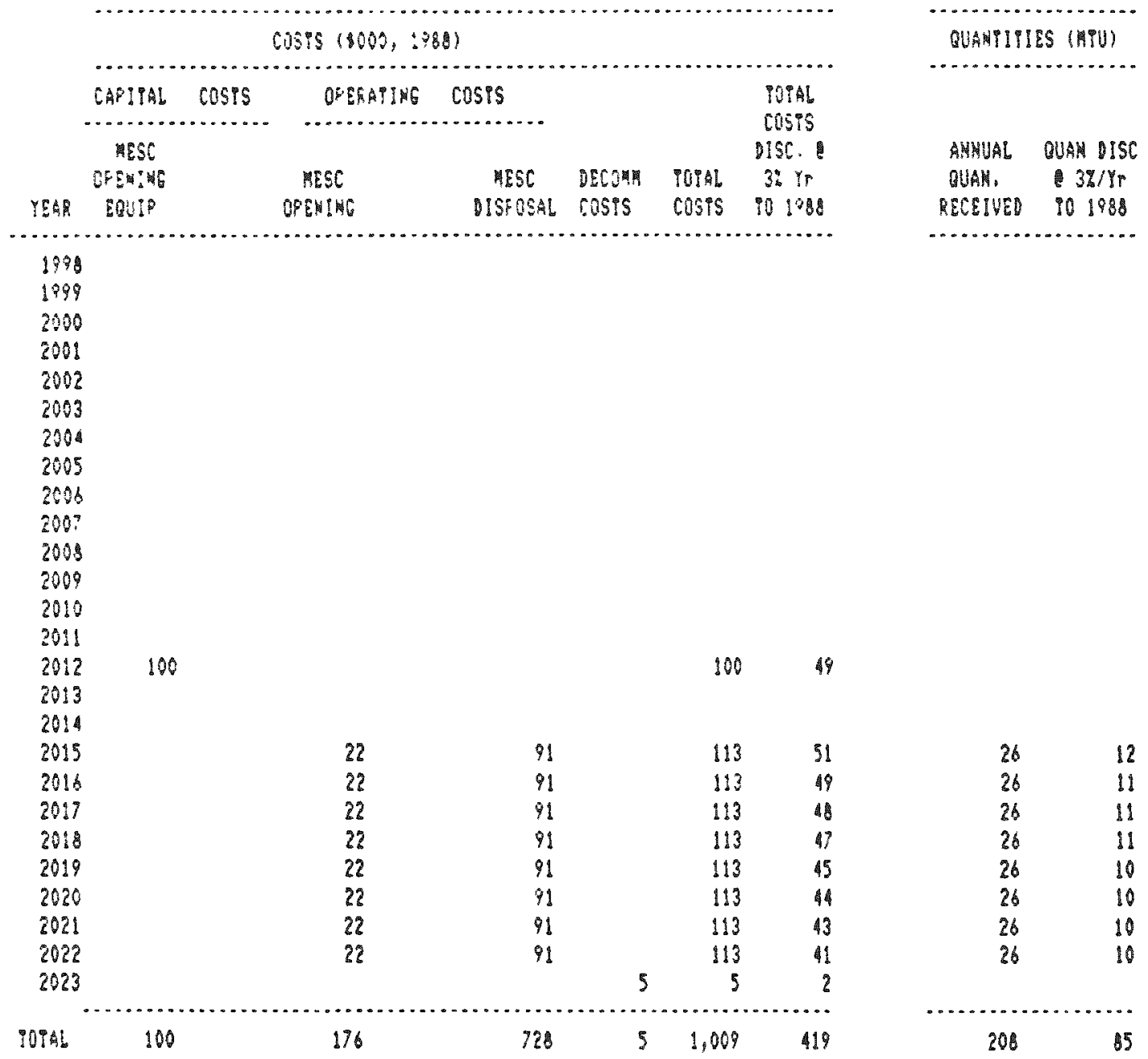

DISC TOTAL

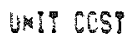

ior kgli

49

78

29

.58

.85

3.50

2419

1 OF IC. AL

MIsC Cos?

$12 \%$

174

$71 \% \quad 0 \% \quad 100 \%$ 
PARLE E-15

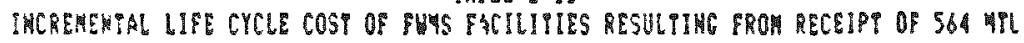

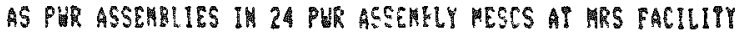

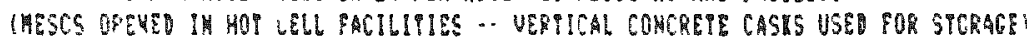

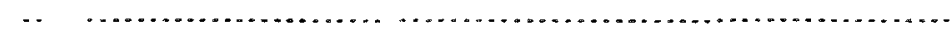

Cojis 10000,1988$)$

\begin{tabular}{|c|c|c|c|c|c|c|c|c|c|c|}
\hline CAPIPA & AL COSTS & & Obsh & IIIMG & SIS & & & I09AL & & \\
\hline & & & $\ldots . . . .$. & .... & $\ldots$ & & & cosis & & \\
\hline MOP & & & rot & & & & & IIS:. & AMNUAL & OUAM ISO \\
\hline $\begin{array}{c}\text { CELb } \\
\text { PACIUIIES }\end{array}$ & $\begin{array}{c}\text { SPORAGE } \\
\text { PABS }\end{array}$ & $\begin{array}{l}\text { MRS } \\
\text { CASYSS }\end{array}$ & $\begin{array}{c}\text { CELL } \\
\text { PA.N1L. IIES }\end{array}$ & $\begin{array}{c}\text { SPOAAGE } \\
\text { AREA }\end{array}$ & $\begin{array}{c}\text { MESC } \\
\text { DISPOSAL }\end{array}$ & $\begin{array}{l}\text { Decomm } \\
\text { cosis }\end{array}$ & $\begin{array}{l}\text { TOTAL } \\
\text { COSTS }\end{array}$ & $\begin{array}{c}3 \% / Y P \\
1 \mathrm{C} 1988\end{array}$ & $\begin{array}{l}\text { OUAM: } \\
\text { RECEIVED }\end{array}$ & $\begin{array}{l}3 \% / Y \mathrm{P} \\
\text { Po } 1988\end{array}$ \\
\hline
\end{tabular}

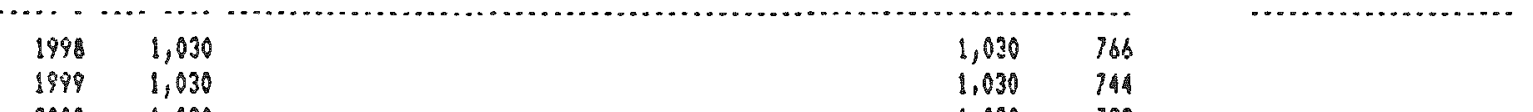

$2000 \quad 1,030 \quad 1,030 \quad 722$

$2001 \quad 1,030 \quad 1,030-701$

$2002 \quad 1,030 \quad 1,030 \quad 601$

$\begin{array}{llll}2003 & 175 & 175 & 112\end{array}$

$2004 \quad 175 \quad 175 \quad 109$

$2005 \quad 175 \quad 175-196$

$2006-175 \quad 175 \quad 103$

$\begin{array}{llll}2007 & 175 & 175 & 100\end{array}$

$\begin{array}{llll}2009 & 175 & 175 & 97\end{array}$

$\begin{array}{llll}2009 & 175 & 175 & 94\end{array}$

$2010 \quad 175 \quad 175 \quad 91$

$201101750175 \quad 39$

$2012 \quad 175 \quad 175 \quad 175$

$3013 \quad 175$

$2014 \quad 175 \quad 175$

$\begin{array}{llll}2015 & 175 & 175 & 79\end{array}$

$2016 \quad 175 \quad 175076$

$2017 \quad 175 \quad 175 \quad 74$

$2018 \quad 175 \quad 175 \quad 72$

$2018 \quad 175 \quad 175 \quad 70$

$\begin{array}{lllllll}2020 & 35 & -320 & 175 & 2 & -108 & -42\end{array}$

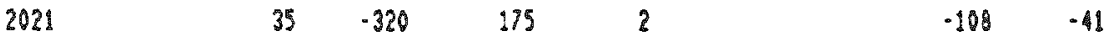

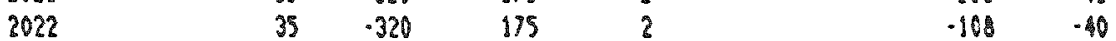

$2023 \quad 175 \quad 175 \quad 62$

$2024 \quad 175 \quad 175 \quad 60$

$2025 \quad 175 \quad 175 \quad 59$

$\begin{array}{lllll}2026 & 175 & 175 & 57\end{array}$

$2027 \quad 293 \quad \& \quad 1,972 \quad 1,771 \quad 559$

$\begin{array}{lllll}2028 & 175 & -13 & 132 & 40\end{array}$

$2029 \quad 175 \quad 175 \quad 52$

$2030175 \quad 175 \quad 51$

$\begin{array}{llll}2031 & 175 & 175 & 49 \\ 2032 & 175 & 175 & 48\end{array}$

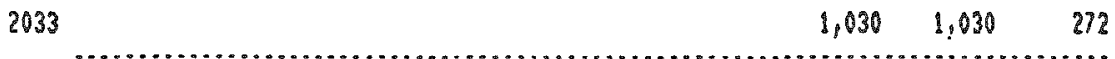

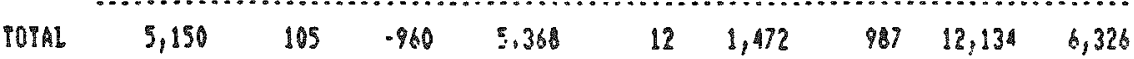

DISC PC:AL

IHII CDST

(per ģu!

$\begin{array}{lllllll}3,815 & 40 \quad-342 & 2,305 & 4 & 465 & 259 & 8,366\end{array}$

$\begin{array}{llllllll}17.00 & .19 & -1.70 & 10.84 & .02 & 2.19 & 1.22 & 29.74\end{array}$

\% OF TIAL

DISC CESP

$\begin{array}{llllllll}57 \% & 1 \% & -6 \% & 36 \% & 0 \% & 7 \% & 4 \% & 106 \%\end{array}$


PAPLE E-16

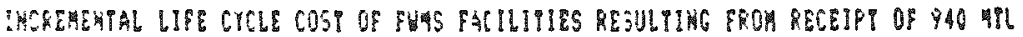

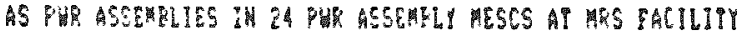

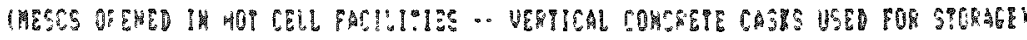

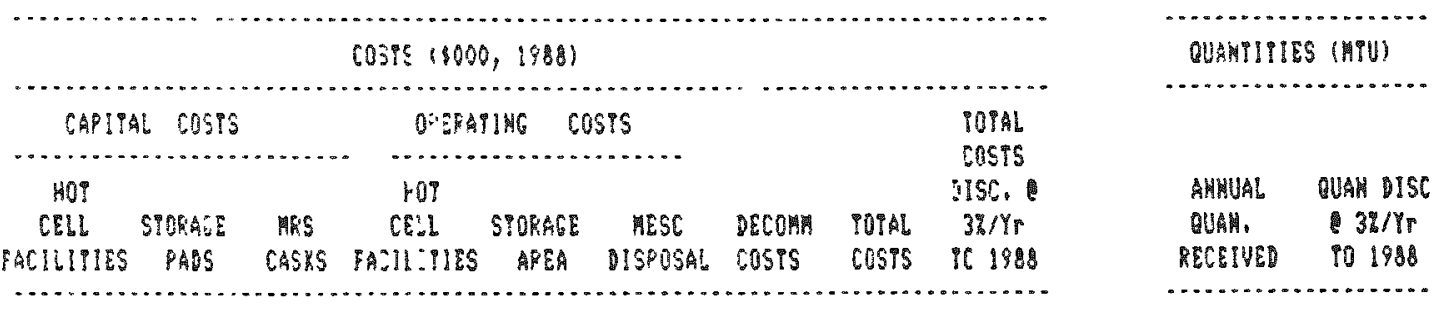

$1998 \quad 1,030$

$1999 \quad 1,030$

20001,030

$2001 \quad 1,030$

$2002 \quad 1,030$

2003

2004

2005

2006

2007

2008

3004

2010

2011

2012

2013

2014

2015

2018

2017

2018

2019

2020

2021

$202 ?$

2023

2024

2025

2028

2027

2028

2029

2030

2031

$203 ?$

2033

TOTAL

$n^{2}+x^{2}$

195

175

175

175

175

175

175

175

175

175

175

175

175

175

$\$ 75$

$33-320$

$33-320$

$33-320$

$33-320$

$\begin{array}{ll}33 & -320 \\ & -320\end{array}$

$$
175
$$

$$
\begin{aligned}
& 175 \\
& 175
\end{aligned}
$$

175$$
175
$$

$$
\begin{aligned}
& 175 \\
& 175
\end{aligned}
$$

$$
375
$$

$$
175
$$

$$
175
$$

$$
175
$$

$$
372
$$$$
175
$$

$$
175
$$

$$
175
$$$$
175
$$

175

$$
10 \quad 2,453
$$

$1,650 \quad 766$

$1,030 \quad 744$

$\begin{array}{ll}1,030 & 722\end{array}$

$1,030 \quad 701$

$1,030 \quad 881$

$175 \quad 112$

$175 \quad 109$

$175 \quad 106$

$175 \quad 103$

$175 \quad 100$

$175 \quad 97$

17594

17599

$175 \quad 89$

175

175

175

175

175

175

.110

.110

$-110$

$-110$

110

.110

$: 75$

175

$\$ 75$

175

17257

$.835 \quad 195$

$\begin{array}{lll}-72 & 103 & 32\end{array}$

$175 \quad 51$

$175 \quad 49$

175 48

$, 030 \quad 1,030 \quad 272$

$958 \quad 13,593 \quad 6,419$

940

$\begin{array}{ll}188 & 77 \\ 188 & 75 \\ 185 & 75 \\ 188 & 71 \\ 188 & 69\end{array}$

0150 Moish

UMIY COST

(per kov)

1 OF POTAL

DISC CCST

$5,150 \quad 165 \quad-1,600 \quad 5,447$

$3,115 \quad \$ 4 \quad .22 \quad 2,330$

$9.90 \quad .18 \quad-1.70 \quad 6.30$

7775

$250 \quad 8,419$

$.69 \quad 17.57$

568

$.10 \%$

$36 \%$

$0 \% \quad 122$

$4196 \%$

17 
TAKLE E-17

IMCEEKENTAL IIFE CYCLE COSP OF FHYS FACULIIES RESULTING FROH RECEIPI OF 1504 HTU AS PUR ASSEULIES IN 24 PUR ASSEKRLY HESCS AT HES FACILITY

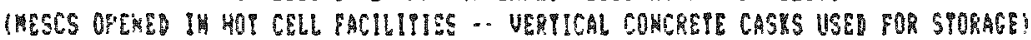
cosis 19090,1980$)$

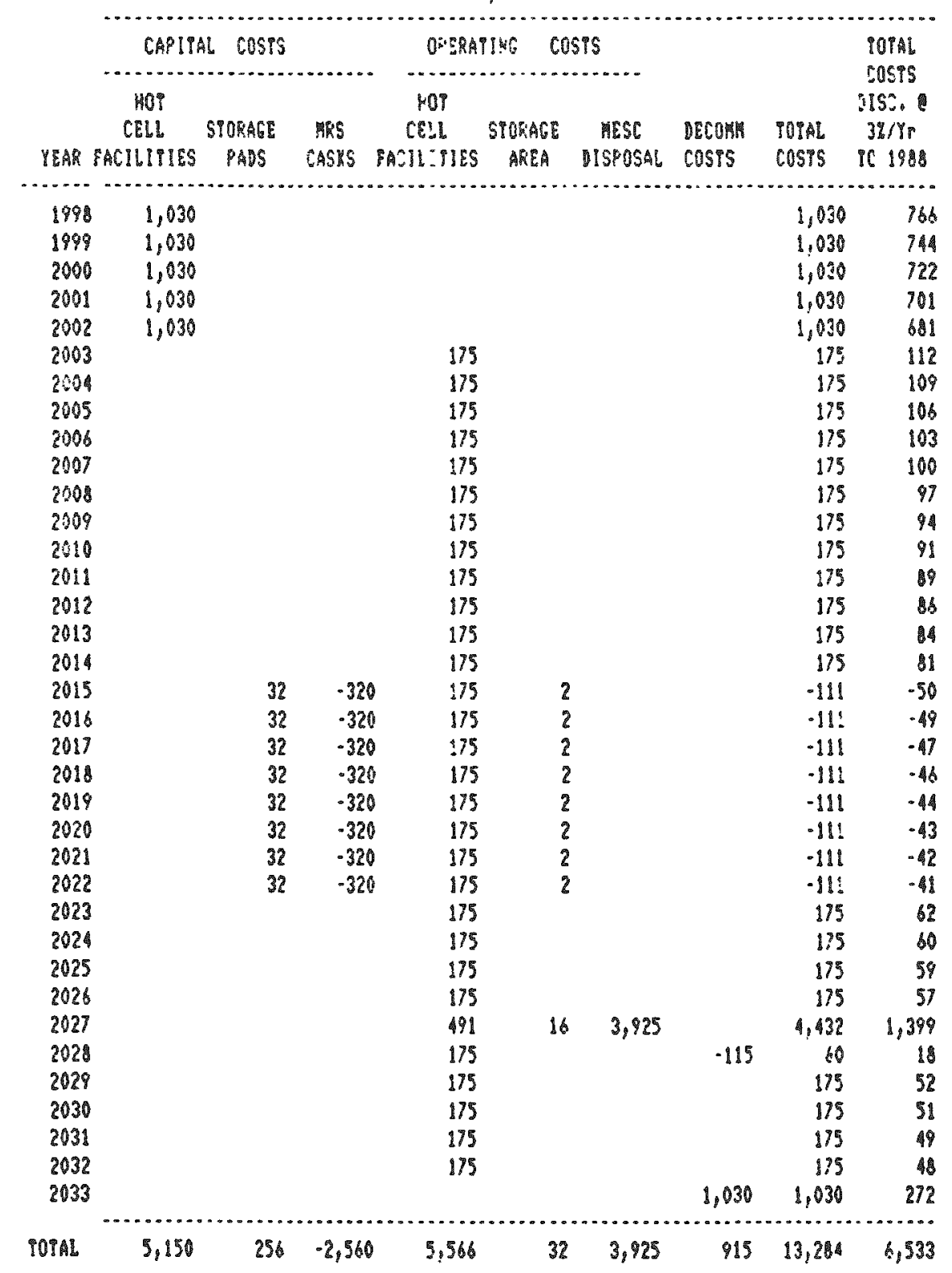
YEAR FACILIIIES PAOS GASHS BATILTIES AREA DISPOSAL COSTS COSTS IC 193

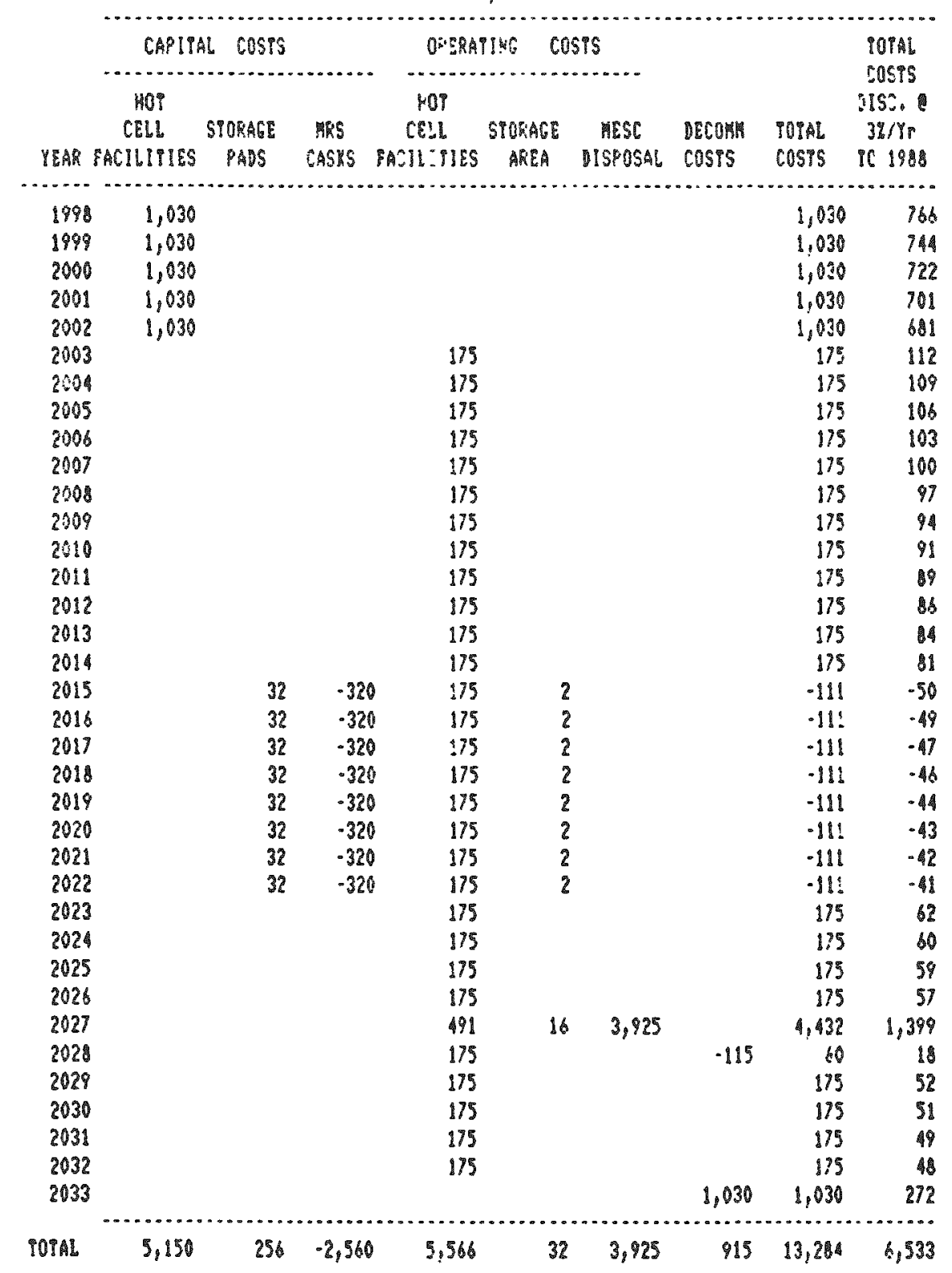

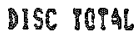

UHII COST ler hous

20 OP POAL DISC COST

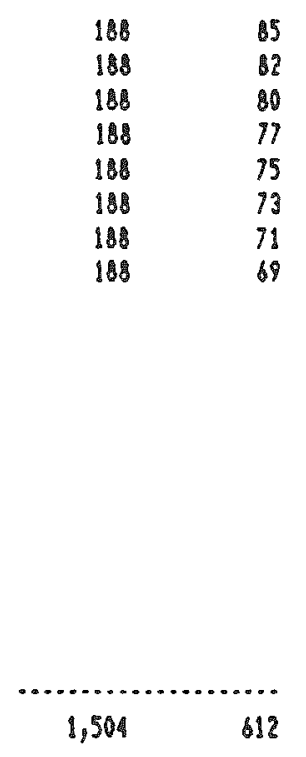


TARLE E-1B

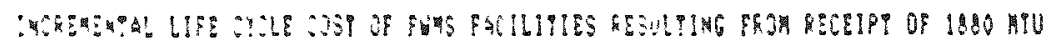

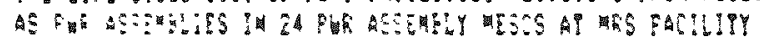

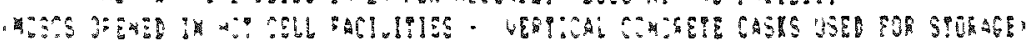

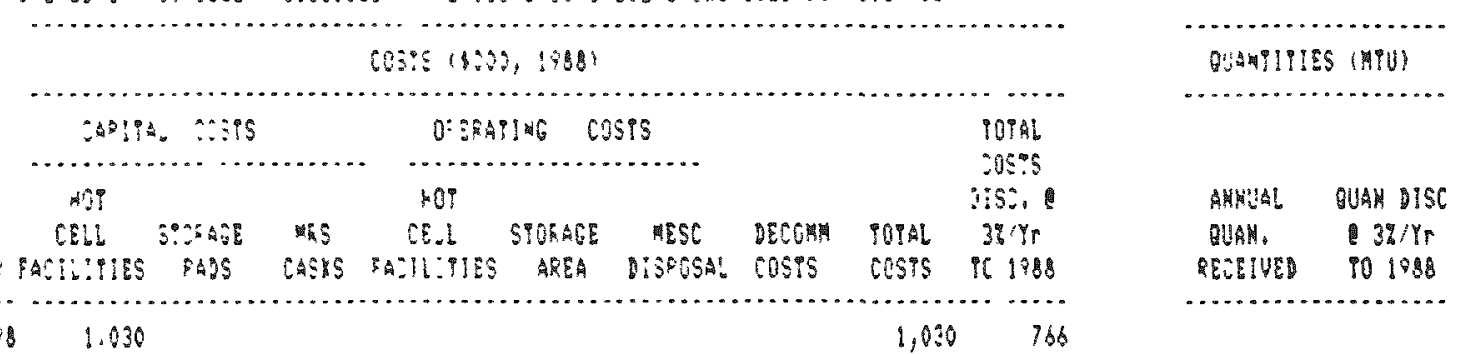

\begin{tabular}{|c|c|c|c|c|c|c|c|c|c|}
\hline 1998 & 1.030 & & & & & & & $1,0: 0$ & 766 \\
\hline $19 \% 9$ & 1.330 & & & & & & & 1.030 & 914 \\
\hline 5000 & 1.830 & & & & & & & 1,030 & 722 \\
\hline 2001 & 1,838 & & & & & & & 1.031 & 901 \\
\hline 8922 & 1,330 & & & & & & & 1,080 & 681 \\
\hline 2003 & & & & $: 75$ & & & & 375 & 112 \\
\hline 2004 & & & & 195 & & & & 175 & 109 \\
\hline 2705 & & & & $: 98$ & & & & 175 & 106 \\
\hline 2068 & & & & 175 & & & & $1 ? 5$ & 103 \\
\hline $2 \operatorname{tin}^{7}$ & & & & $: 95$ & & & & 175 & 100 \\
\hline 20:5 & & & & 175 & & & & 195 & 97 \\
\hline 2999 & & & & $: 75$ & & & & 175 & 94 \\
\hline 8010 & & & & 175 & & & & 175 & 91 \\
\hline 2011 & & & & 175 & & & & 875 & 89 \\
\hline 2012 & & & & 175 & & & & 175 & $b$ \\
\hline 2013 & & 31 & $-32 A$ & .75 & 2 & & & -993 & .53 \\
\hline 2614 & & 31 & -36 & 175 & 2 & & & .112 & .52 \\
\hline 2015 & & 31 & -323 & $: 75$ & 2 & & & .112 & .50 \\
\hline 2016 & & $3 !$ & $\cdot 320$ & 195 & 2 & & & .112 & -49 \\
\hline 6017 & & 31 & -320 & 175 & 2 & & & .112 & -48 \\
\hline $20 ! 5$ & & 31 & -320 & 175 & 2 & & & .112 & -46 \\
\hline 2019 & & 31 & -320 & $: 75$ & 2 & & & .112 & -45 \\
\hline 2220 & & $3 !$ & .320 & 175 & 2 & & & .112 & -43 \\
\hline 2021 & & 31 & .320 & 175 & 2 & & & .112 & .42 \\
\hline $202 ?$ & & $3 !$ & -320 & 175 & 2 & & & .112 & .41 \\
\hline 2023 & & & & 175 & & & & 175 & 62 \\
\hline 3024 & & & & 175 & & & & 175 & bo \\
\hline 2035 & & & & 175 & & & & 975 & 59 \\
\hline 2528 & & & & 175 & & & & 175 & 57 \\
\hline 2027 & & & & 570 & 20 & 4,907 & & $5.49 \%$ & 1,736 \\
\hline 2028 & & & & 175 & & & .145 & 30 & 9 \\
\hline 2029 & & & & 175 & & & & 175 & 52 \\
\hline 2030 & & & & 993 & & & & 195 & 51 \\
\hline 2031 & & & & 175 & & & & 198 & 49 \\
\hline 2032 & & & & 175 & & & & 175 & 48 \\
\hline 2033 & & & & & & & 1,030 & 1.030 & 272 \\
\hline 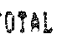 & 5,150 & 310 & $-3,200$ & $\frac{8}{.645}$ & 40 & 4,997 & 85 & 13,737 & 6,587 \\
\hline
\end{tabular}

BI 150 10.4:

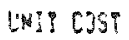

uer hạu:

$\begin{array}{llllllll}3,615 & 130 & -1,313 & 2,392 & 15 & 1,549 & 228 & 0,589 \\ 4.58 & .16 & -1.70 & 3.03 & .02 & 1.86 & .29 & 0.35\end{array}$

\ JF 394

$\sec \cos$

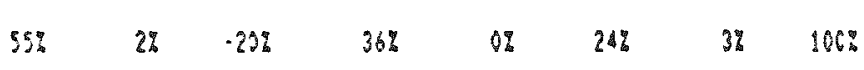


TARLE E-19

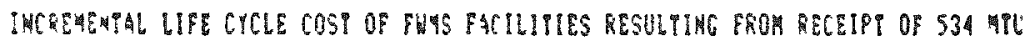

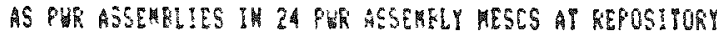
(HESCS OFEWE JW HUI :ELL FACULIIISS)

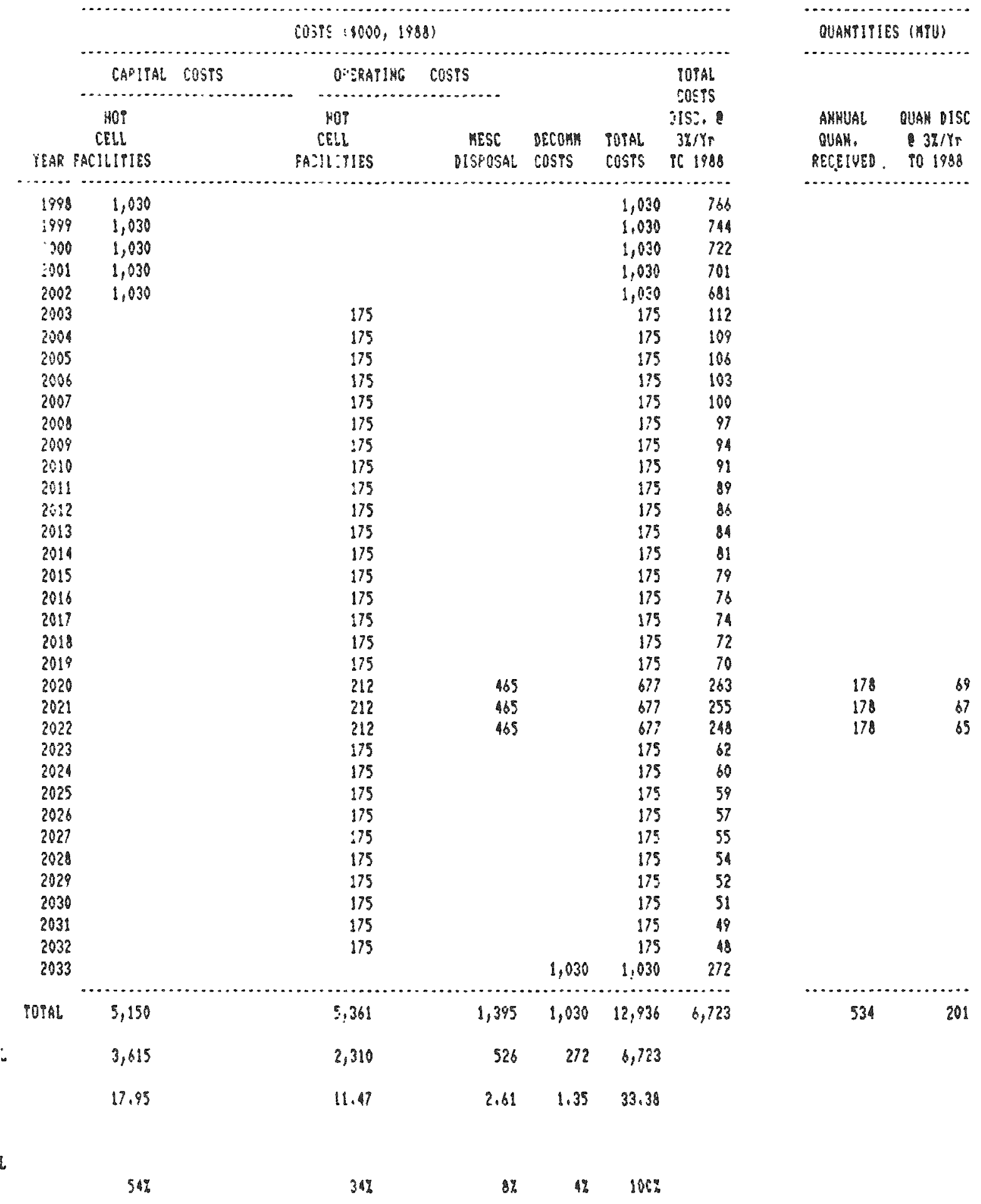


IABLLE E-20

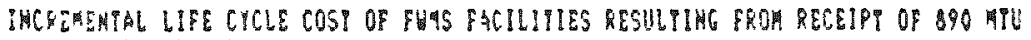

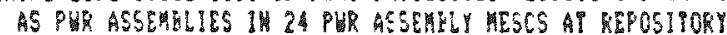

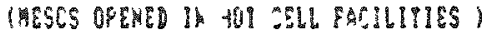

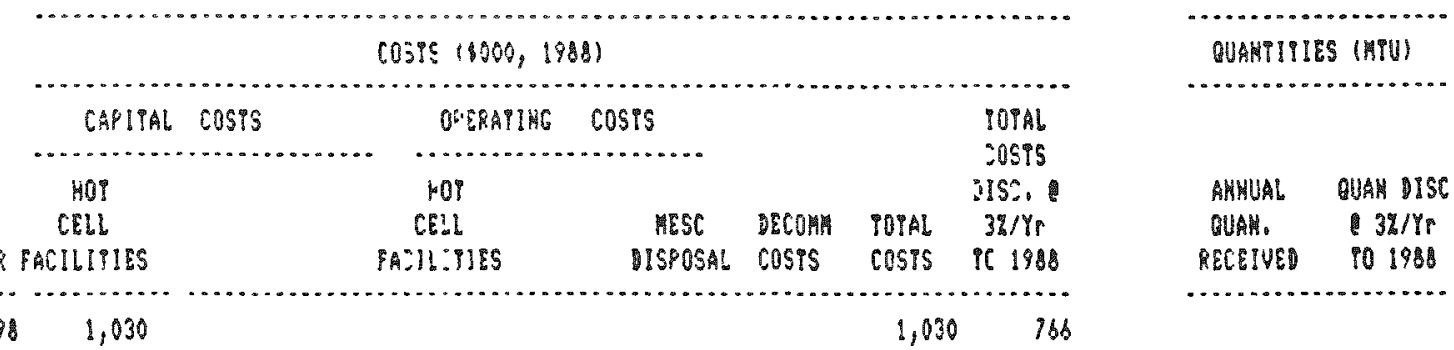

$2000 \quad 1,030$

$2001 \quad 1,030$

$2002 \quad 1,030$

2003

2004

2005

2006

2007

2008

2009

2010

2011

2012

2013

2014

2015

2016

2017

2018

2018

2020

2021

2022

2023

2024

2025

2028

2027

2028

2029

2030

2031

2032

2033

175

175

175

175
175

175

175
175

175

212

212

212

312

$21 ?$

$: 75$

175

175

175

475

175

175

175

175

175

$175 \quad 106$

$175 \quad 103$

$175 \quad 190$

17597

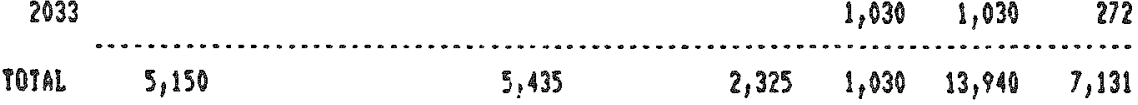

DISC I0T4

UNI Cดร

(per họu)

2 OF TOTAL

disc cos?
3,615

2,340

904

$2727,13 !$

10.45

5.16

2.51

$.79 \quad 20.61$

511

332

$13 \%$

48

$100 \%$

32


PABLE E-21

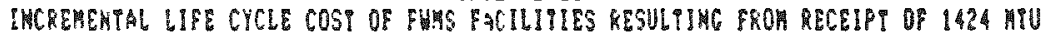

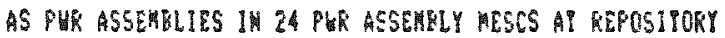

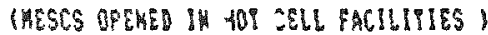

Cosis 11000,1988$)$

CAPIPAL COSTS
nOT
CELL

YEAR PACILIIIES

0:BAIIHG COSTS

10\%月L

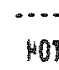

CEL PANHLIIES

$$
1998
$$

1999

2000

2001

2002

2003

2004

2005

2006

2007

2008

2004

2010

2011

2012

2013

2014

2015

2016

2017

2018

2019

2020

2021

2022

2023

2024

2025

2026

2027

2028

2029

2030

2031

203 ?

2033

TOIAL

\section{1,030}

1,030

1,030

1,030

1,030

175

175

175

175

175

175

175

175

175

175

175

175

212

212

212

212

212

212

212

212

175

175

175

175

175

175

175

175

175

175 cosps

ins..

TESC DECOM TOPAL $3 \% / Y \mathrm{~T}$ DISFOSAL COSTS COSTS 10 1988 ...................................

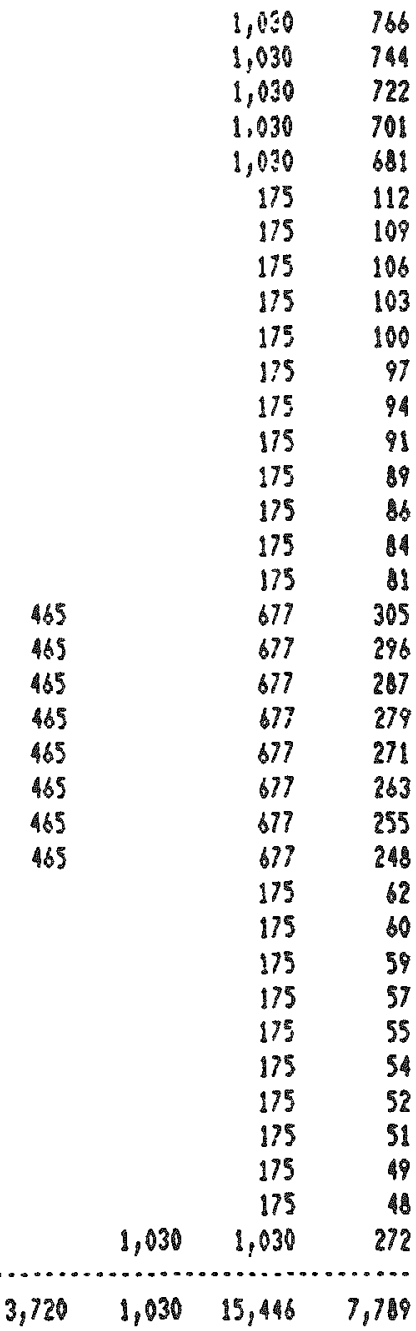

$\begin{array}{ll}178 & 80 \\ 178 & 78 \\ 178 & 76 \\ 178 & 73 \\ 178 & 71 \\ 178 & 68 \\ 178 & 67 \\ 178 & 65\end{array}$

1,12
WUAMIYIES (ITU)

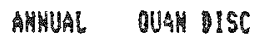

QUAM. $3 \% / \%$

RECENEO TO 1980
DISC Mo:Al

HII CJSP

(per kogl)

* of TJTAL

Disc Cost$$
3,15
$$

8.29

$48 \%$

318

4.12
$2,514 \quad 272 \quad 7,799$

$2.61 \quad .47 \quad 13.14$

$19 \% \quad 32 \quad 106 \%$ 
TARLE $P-22$

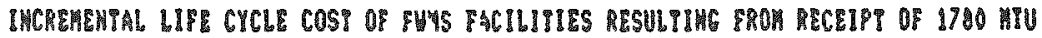
AS PUR ASSEWLIES IV 24 PUR AESEMLY MESCS M REPOSIYORY

(MESCS OPEMEI IN HOT CEL FACHLIIIES)

cos̄is 10000,1985$)$

OUAMTIIIS (MT)

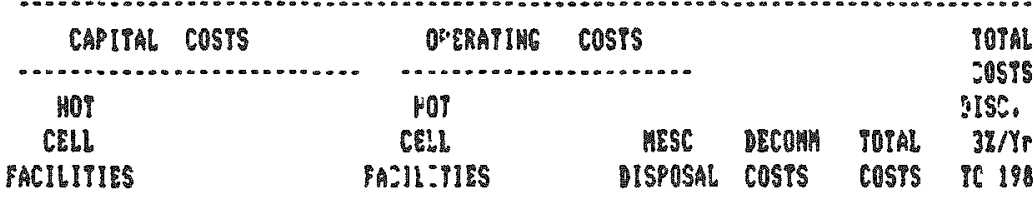

\begin{tabular}{|c|c|c|c|c|c|c|c|c|}
\hline \multicolumn{2}{|c|}{ VEAT FACILIIIES } & PA:HL:TIES & ISPOSAL & Cosps & costs & If 1986 & \multirow[t]{2}{*}{ RECETVE } & \multirow{2}{*}{ Po 1988} \\
\hline a...... & & $\ldots$ & 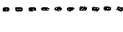 & - $\ldots \ldots$ & $\ldots \ldots$ & n......... & & \\
\hline 1998 & 1,030 & & & & 1,030 & 764 & & \\
\hline 1998 & 1,030 & & & & 1,030 & 744 & & \\
\hline 2000 & 1,030 & & & & 1,030 & 722 & & \\
\hline 2001 & 1,030 & & & & 1,030 & 701 & & \\
\hline 2002 & 1,030 & & & & 1,030 & 681 & & \\
\hline 2003 & & 175 & & & 175 & 112 & & \\
\hline 2004 & & 175 & & & 175 & 109 & & \\
\hline 2005 & & 175 & & & 175 & 106 & & \\
\hline 2008 & & 175 & & & 175 & 103 & & \\
\hline 2007 & & 175 & & & 175 & 100 & & \\
\hline 2005 & & 175 & & & 175 & 97 & & \\
\hline 2008 & & 175 & & & 175 & 91 & & \\
\hline 2010 & & 175 & & & 175 & 91 & & \\
\hline 2011 & & 175 & & & 175 & 99 & & \\
\hline 2012 & & 175 & & & 175 & 86 & & \\
\hline 2013 & & 212 & 465 & & 677 & $32^{3}$ & 178 & 85 \\
\hline 2014 & & 212 & 465 & & $67 \%$ & 314 & 178 & 3 \\
\hline 2015 & & 212 & 465 & & 677 & 305 & 176 & 60 \\
\hline 2016 & & 212 & 465 & & 67 & 296 & 178 & 78 \\
\hline 2017 & & 212 & 485 & & 677 & 287 & 170 & 76 \\
\hline 2018 & & 212 & 465 & & $67 \%$ & 279 & 17 है & 73 \\
\hline 2018 & & 212 & 485 & & 697 & 271 & 1718 & 71 \\
\hline 2020 & & 212 & 465 & & 67 & 283 & 176 & 69 \\
\hline 2021 & & 212 & 485 & & 877 & 255 & 178 & 67 \\
\hline 3022 & & 212 & 465 & & $67 \%$ & 24 & 178 & 65 \\
\hline 2023 & & 175 & & & 175 & 82 & & \\
\hline 2021 & & 175 & & & 175 & 80 & & \\
\hline 2025 & & $\$ 75$ & & & 175 & 5 & & \\
\hline 2026 & & 175 & & & 175 & 5 & & \\
\hline 2027 & & 175 & & & 175 & 35 & & \\
\hline 2028 & & 175 & & & 175 & 54 & & \\
\hline 2029 & & $\$ 75$ & & & 175 & 52 & & \\
\hline 2030 & & 175 & & & 175 & 51 & & \\
\hline 2031 & & 175 & & & 175 & 49 & & \\
\hline 2032 & & 175 & & & 175 & 48 & & \\
\hline 2033 & & & & 1,030 & 1,030 & 272 & & \\
\hline POTAL & 5.150 & 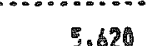 & 4.650 & 1.03ิ & 14.95 & 249 & 19B & 747 \\
\hline Borma & 21828 & 28000 & 91020 & 19030 & 10,980 & 0,608 & 1 geres & 78 \\
\hline & 3,615 & 2,423 & 1,951 & 272 & 8,262 & & & \\
\hline & 4.84 & 3.24 & 2.61 & .36 & 11.08 & & & \\
\hline & 442 & $29 \%$ & $24 \%$ & 32 & $100 \%$ & & & \\
\hline
\end{tabular}

IISC POPAL

UMI CIST

Iper kẹut

1 OF TITAL

DISC COST

448 
IARLE -23

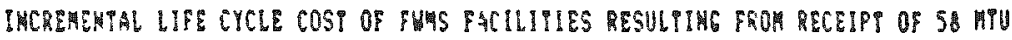

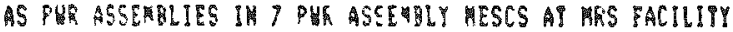

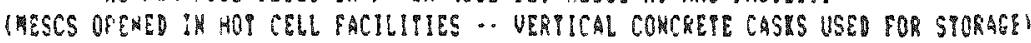

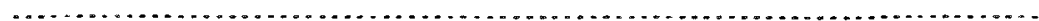
Cosis $(8000,1988)$

OUARIIIES (พT⿱卄一)

\begin{tabular}{|c|c|c|c|c|c|c|c|c|c|c|}
\hline CAPIIS & Al cosIs & & $0^{B} \mathrm{ERA}$ & 11146 & SIS & & & TOTAL & & \\
\hline & & 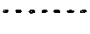 & c.....- & & $\cdots \cdot$ & & & cosis & & \\
\hline $40 ?$ & & & NoT & & & & & ISC, & AMHUAL & QUAN DISC \\
\hline CLL & CTRAGE & 解s & CEbL & SYOAGE & HESC & DECOH & POTAL & $3 \% / Y_{r}$ & OUABH. & $32 / 1 / r$ \\
\hline PACIUIIISS & PABS & CASIS & PA:IL:MIES & AREA & DISPOSAL & COSTS & COSTS & If 1988 & RECEIVED & 901988 \\
\hline
\end{tabular}

\begin{tabular}{|c|c|c|c|c|c|c|c|c|}
\hline 1998 & 114 & & & & & & & 114 \\
\hline 1999 & 111 & & & & & & & 114 \\
\hline 2000 & 114 & & & & & & & 114 \\
\hline 2001 & 114 & & & & & & & 114 \\
\hline 2002 & 114 & & & & & & & 114 \\
\hline 2003 & & & & 19 & & & & 19 \\
\hline 2004 & & & & 19 & & & & 19 \\
\hline 2005 & & & & 19 & & & & 19 \\
\hline 2000 & & & & 19 & & & & 19 \\
\hline 2007 & & & & 19 & & & & 19 \\
\hline 2008 & & & & 19 & & & & 19 \\
\hline 2009 & & & & 19 & & & & 19 \\
\hline 2010 & & & & 19 & & & & 18 \\
\hline 2011 & & & & 19 & & & & 19 \\
\hline 2012 & & & & 19 & & & & 19 \\
\hline 2013 & & & & 19 & & & & 19 \\
\hline 3214 & & & & 19 & & & & 18 \\
\hline 2015 & & & & 19 & & & & 19 \\
\hline 2016 & & & & 18 & & & & 10 \\
\hline 2017 & & & & 19 & & & & 19 \\
\hline 2018 & & & & 18 & & & & 10 \\
\hline 2019 & & & & 19 & & & & 19 \\
\hline 2020 & & & & 19 & & & & 18 \\
\hline 2021 & & & & 19 & & & & 18 \\
\hline 2022 & & 32 & 416 & 19 & 2 & & & $4 \xi ;$ \\
\hline 2023 & & & & 19 & & & & 10 \\
\hline 2024 & & & & 19 & & & & 18 \\
\hline 2025 & & & & 19 & & & & 19 \\
\hline 2026 & & & & 19 & & & & 18 \\
\hline 2027 & & & & 50 & 2 & 202 & & 262 \\
\hline 2028 & & & & 19 & & & 22 & $4:$ \\
\hline 2029 & & & & 19 & & & & 19 \\
\hline 2030 & & & & 19 & & & & 19 \\
\hline 2031 & & & & 19 & & & & 19 \\
\hline 2032 & & & & 19 & & & & 19 \\
\hline 2033 & & & & & & & 114 & 18 \\
\hline
\end{tabular}

DISC ICTÁ

WII COSP

(ger họb!

$\begin{array}{rrrrrrrr}100 & 12 & 152 & 259 & 1 & 64 & 37 & 994 \\ 18.85 & .55 & 7.14 & 12.18 & .08 & 3.00 & 1.74 & 13.52\end{array}$

4 OF PIAL DISC CLSP

$43 \% \quad$ II $\quad 13 \% \quad 25 \% \quad 0 \% \quad 7 \% \quad 42 \quad 106 \%$


TAELE E- 2I

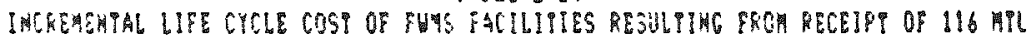
AS PUE ASSEABLIES IH 7 PUK ASEE

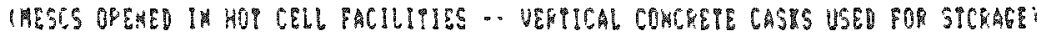

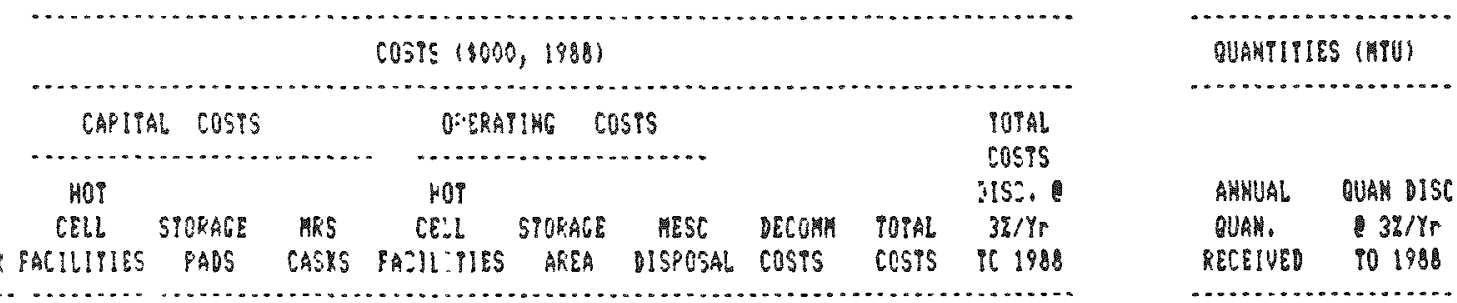

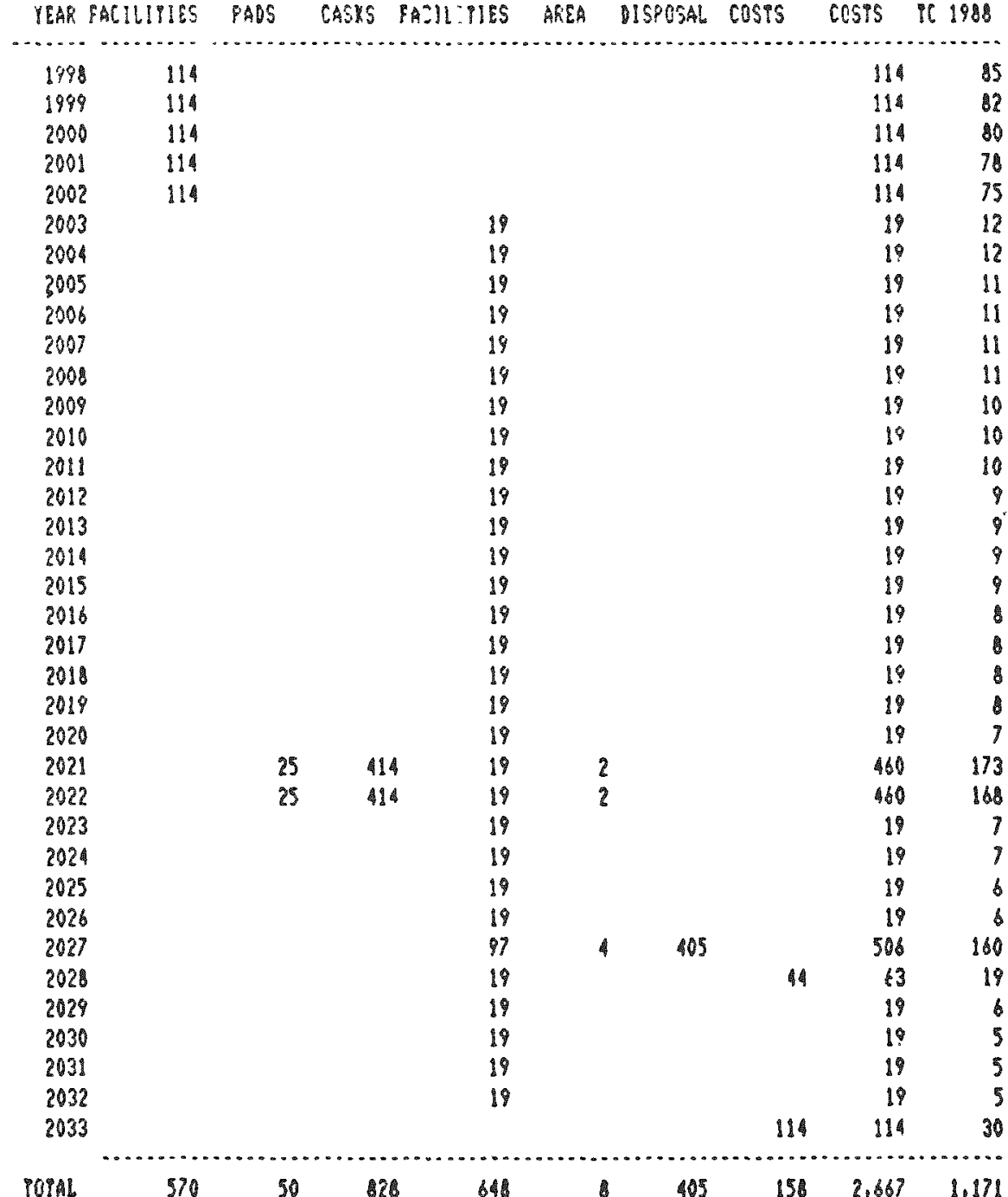

DISC ICPAL

UAIT COSP

Iper houl

$\begin{array}{rrrrrrrr}400 & 19 & 308 & 271 & 3 & 128 & 11 & 1,171 \\ 0.21 & .43 & 7.14 & 6.28 & .06 & 2.97 & 1.01 & 27.11\end{array}$

Y OF POTAL

UISC CAS?

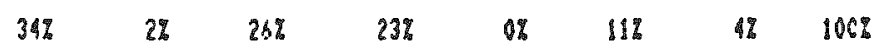


IAYLE -25

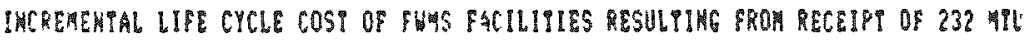
AS PUE ASSEHBLIRS IN 7 PUE ASEEYBLY MESCS AT WES FACILITY

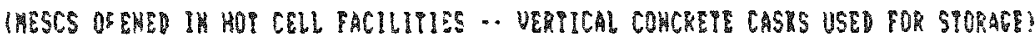

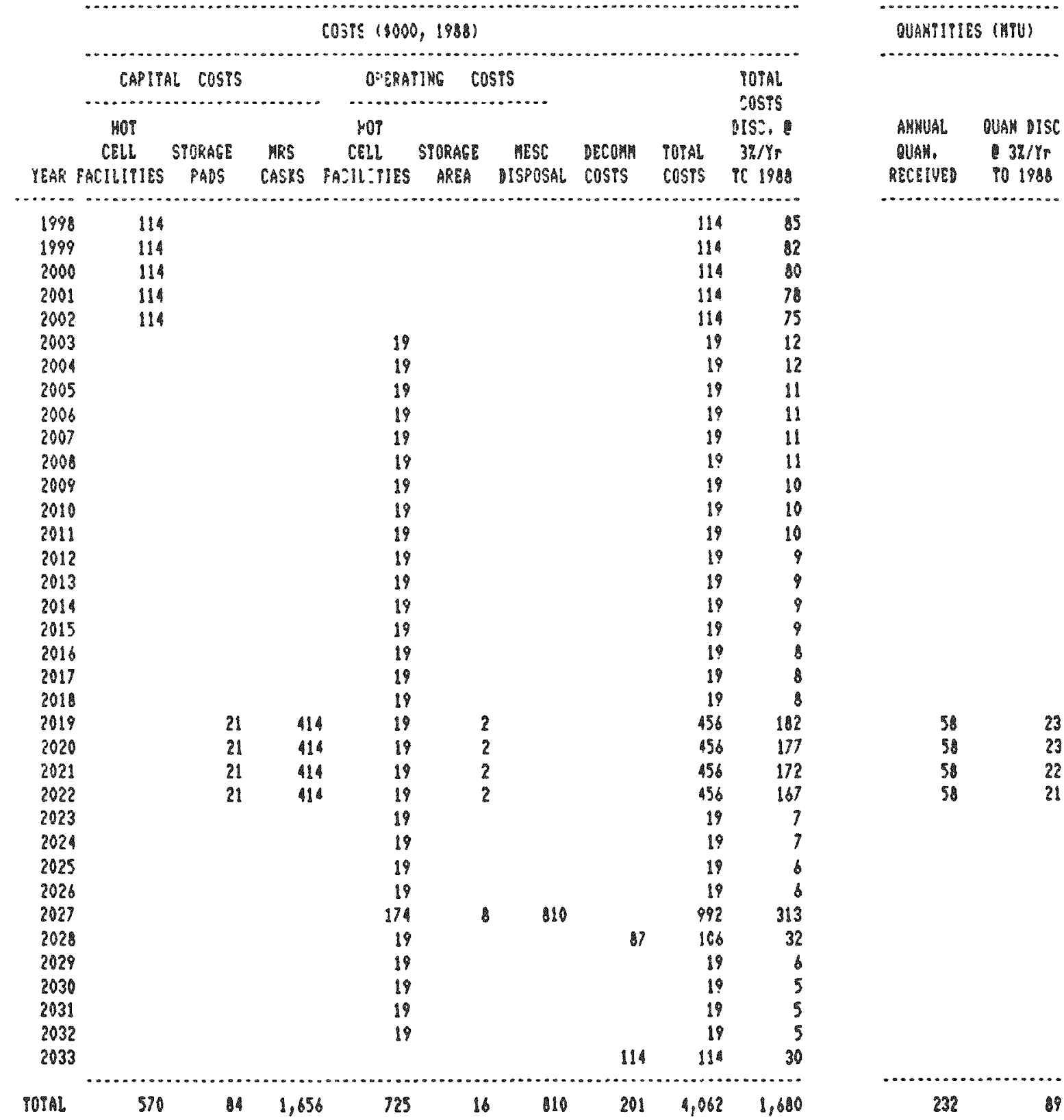

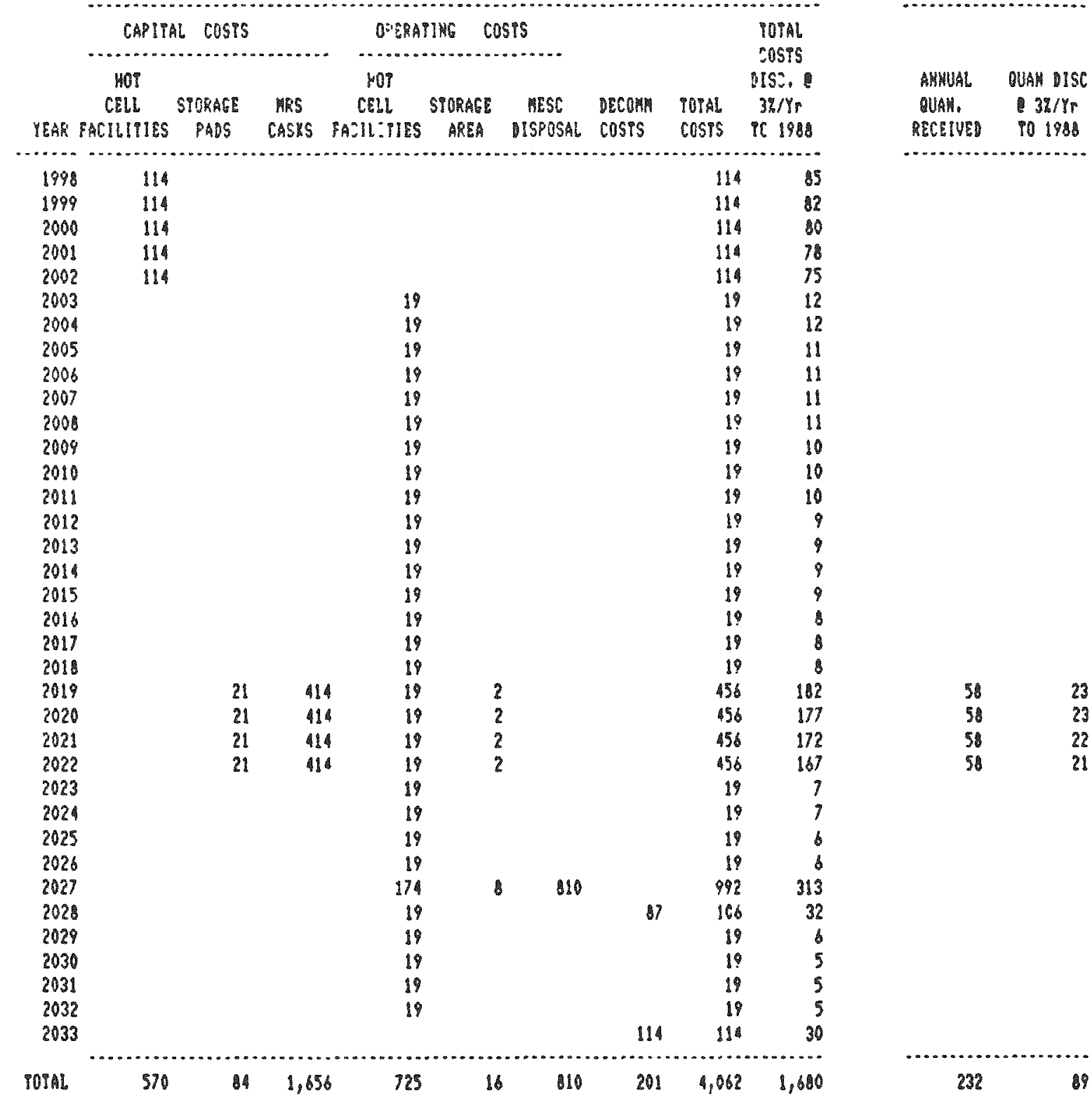

QUAMTIIISS (MTU)

DISC MCEAL

UMIT Cosi foer hẹus

\& OP TOTAL DISC COST

$\begin{array}{rrrrrrrr}400 & 32 & 834 & 295 & 1 & 258 & 57 & 1.600 \\ 4.50 & .36 & 7.14 & 3.32 & .05 & 2.88 & .84 & 18.81\end{array}$

$24 \% \quad 2 \% \quad 38 \% \quad 18 \% \quad 0 \% \quad 15 \% \quad 3 \% \quad 106 \%$ 
PABLE E- 26

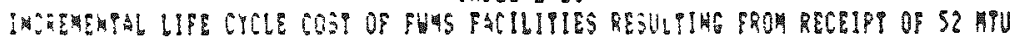

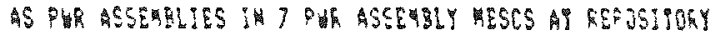

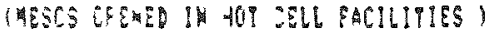

\begin{tabular}{|c|c|c|c|c|c|c|c|}
\hline \multicolumn{6}{|c|}{ Cosis 11000,1988$)$} & \multicolumn{2}{|c|}{ OUAHTIIIES (MTU) } \\
\hline CAPIOAL COSOS & $0: 3897 \times 6$ & cose & & & POTAL & & \\
\hline 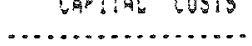 & 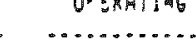 & 69 & & & $\begin{array}{l}\text { 10IAL } \\
\text { COE }\end{array}$ & & \\
\hline 409 & 10\% & & & & IIS:. & 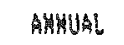 & 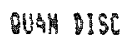 \\
\hline $\begin{array}{l}\text { CELL } \\
\text { ACILITIS }\end{array}$ & $\begin{array}{c}\text { CËL } \\
\text { PA:JL: }\end{array}$ & $\begin{array}{c}\text { MESC } \\
\text { DISPOSAL }\end{array}$ & $\begin{array}{l}\text { DEcom } \\
\text { cosis }\end{array}$ & $\begin{array}{l}\text { POAAL } \\
\text { Cosis }\end{array}$ & $\begin{array}{l}3 \% / Y r \\
161988\end{array}$ & $\begin{array}{l}\text { DUAH } \\
\text { AECE!ทES }\end{array}$ & $\begin{array}{l}3 \% / 1 r \\
101998\end{array}$ \\
\hline
\end{tabular}

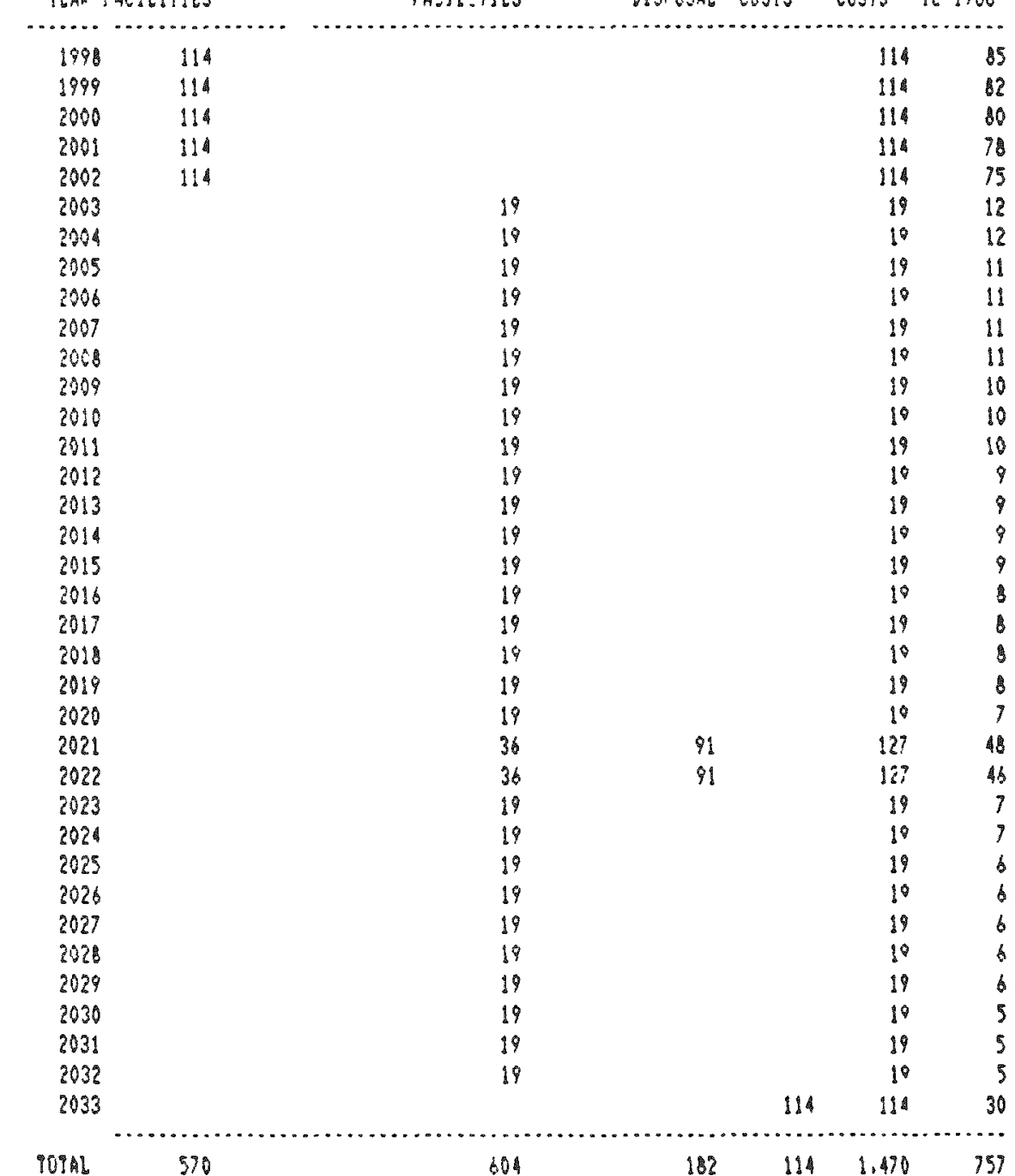

DISC IC:

LWI cos?

Ler liet:

- OB TMPAL DISC C6s?

\begin{abstract}
100
\end{abstract}
20.71

$53 \%$
259

12.40

347
$68 \quad 30 \quad 757$

$3.50 \quad 1.56 \quad 39.17$

$924 \% \quad 216 \%$ 
PALLE E- 27

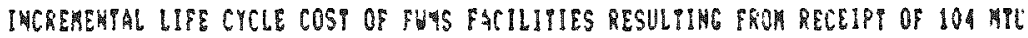
AS PHK ASSEHLLIES IH 7 PUR ASEE IILY HESCS AI REPOSIYORY (AESCS OFEHED IH HOT ZELL FACILIYIES)

c0jps 18000,1988$\}$

CAPITAL COSIS
HOI
CELL

YEAR PACHLIIES

$1998 \quad 114$

$1998 \quad 114$

$2000 \quad 114$

$2001 \quad 114$

$2003 \quad 114$

2003

2004

2005

2006

2009

2008

2009

2010

2011

2012

2013

2014

2015

2016

2017

2018

2019

2020

2021

2022

2023

2024

2025

2026

2027

2028

2029

2030

2031

2032

2033

TOMAL

DISC 90:46

UMIY CSST

(oserouis

$\angle$ OP PIAL

DSc cesp

cosi.................

18

19

19

18

19

19

19

19
19

19

19

19

19
19

19

19

36
36
36

36

19

19

19
19

19
19

19

19

19
19

19
19

19

19

$\quad . . .1$.
57

400

638

272

10.05

64

$32 \%$

48

\begin{tabular}{|c|c|c|c|c|}
\hline O'ERAIING & Cosis & & & YOTAL \\
\hline$\ldots$ & & & & cosis \\
\hline HOP & & & & 115:- \\
\hline CEsL & AESC & DEcom & TOTAL & $3 \% / Y \mathrm{P}$ \\
\hline N1L:IISS & DISPOSAL & cosis & cosis & ic 1988 \\
\hline
\end{tabular}

\%

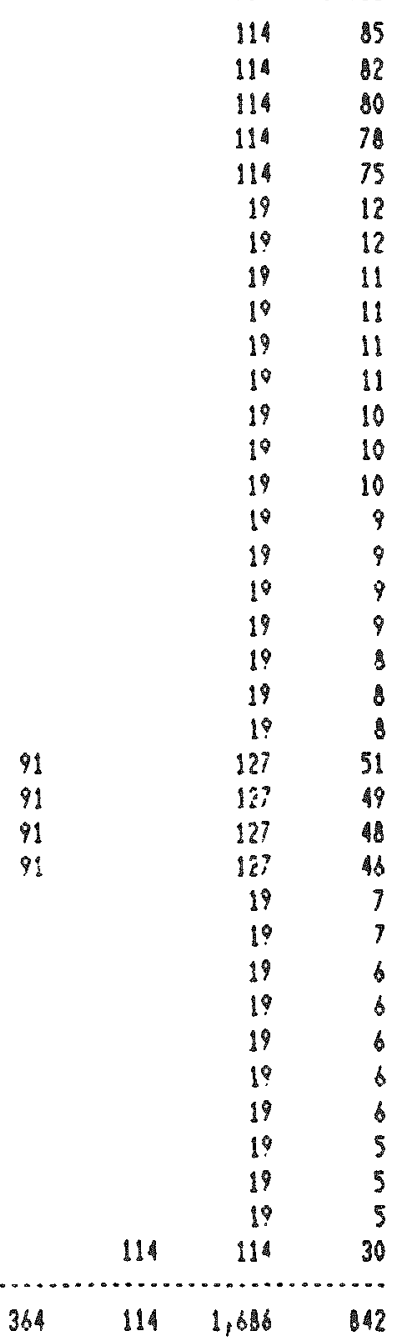

QUAMTIIIES (พบบ)
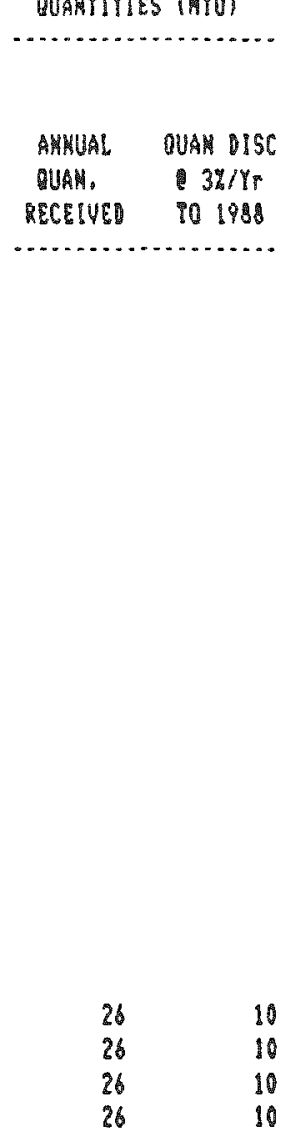

104

40 
PAELE E-2B

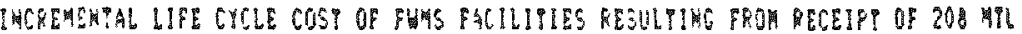

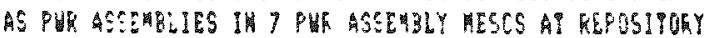

(HESCS OPEMED IN

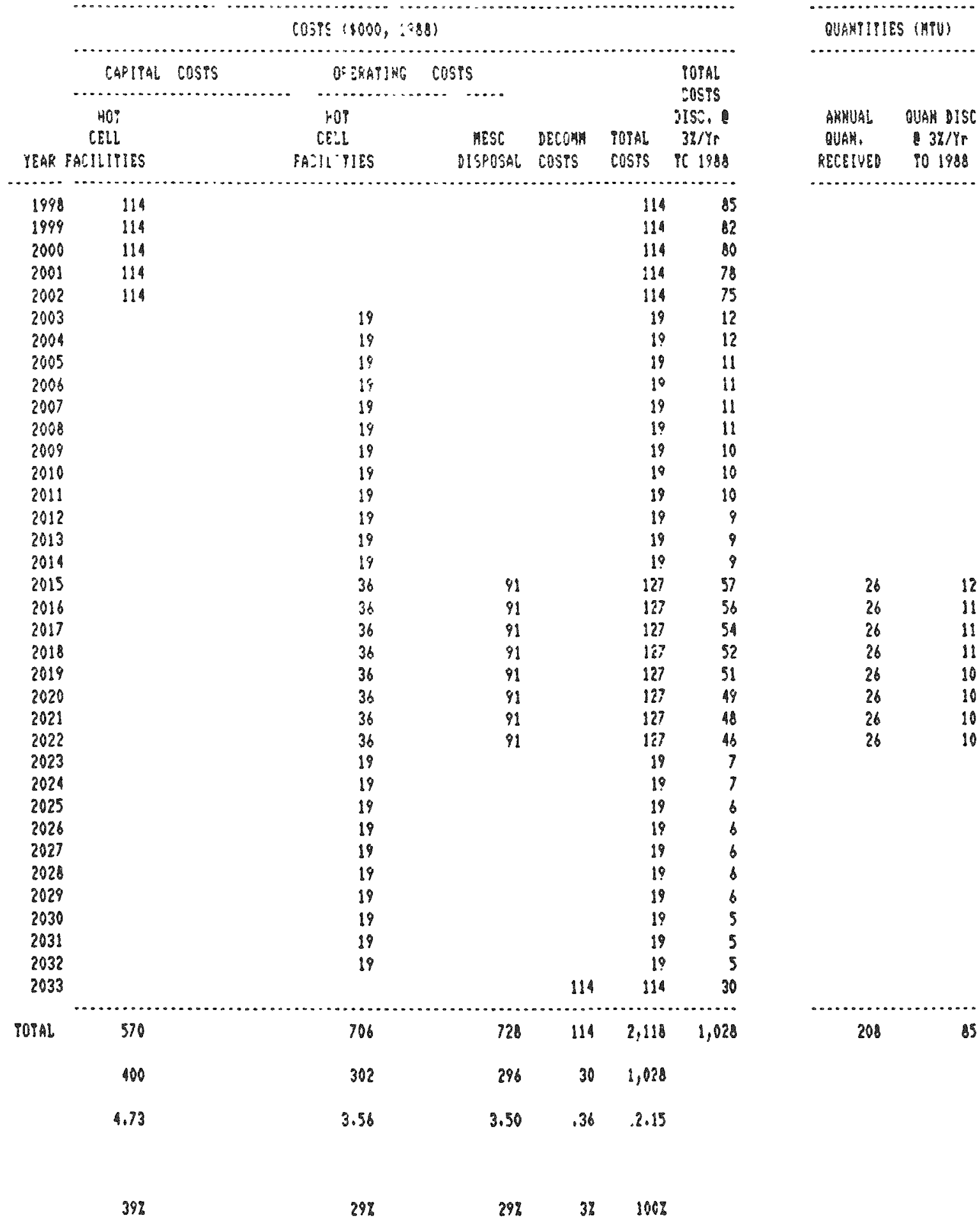

DISC COST

298

$296-3 \% \quad 100 \%$ 
PABLE E-29

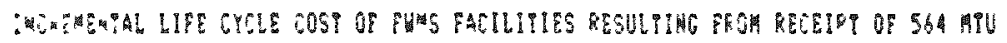
AS P. A A

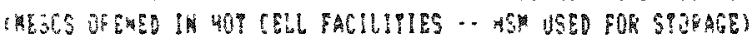

cosis $(1000,198 s)$

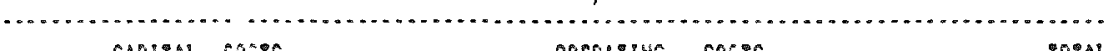

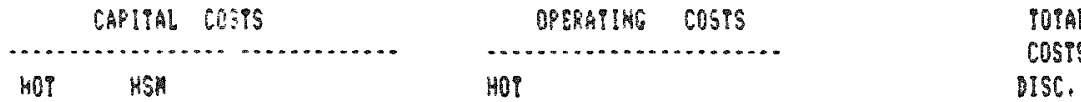

CELL L3RIING PHAYSTER CELL STORAGE MESC DECOM TGTAL 3\%/YT

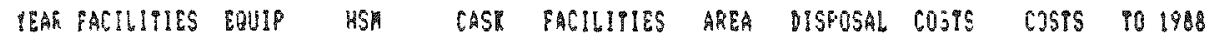

$1,1,0$

$1999 \quad 1,030$

$2000 \quad 1,030$

$2001 \quad 1,030$
$2002 \quad 1,030$

2003

2064

2005

206

2007

2008

2009

2010

2011

2012

$=013$

2014

2015

2016

2017

2018

2019

2020

2021

2022

2023

2024

2025

2026

2027

2028

2029

2030

2031

2032

2033

POTAL

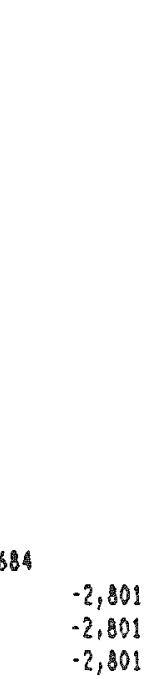

ISC POPAL

UAIT COSP

per hou?

1 OF TJPLL

DISC COS? 5,150

$274 \quad-3,189$

$17.00 \quad 1.29 \quad-14.90$

$91 \% \quad 7 \% \quad-80 \%$

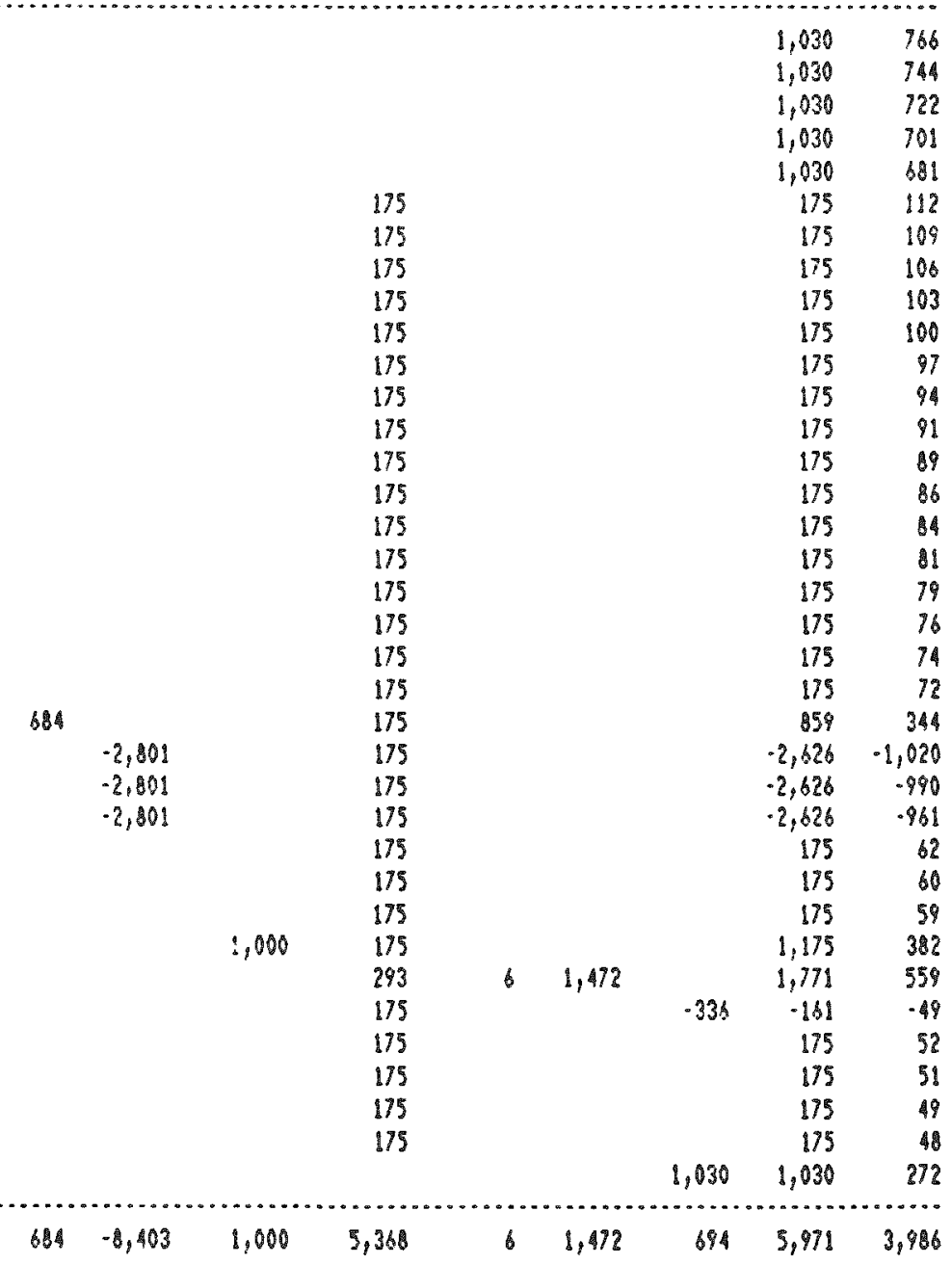

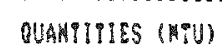

AHKUAL OBA JIS:

QUAK. $3 \% / Y$

RECEIVED PO 1988

$325 \quad 2,305$

2465

$169 \quad 3,886$

1.53

10.84

.01

2.1

$.80 \quad 18.74$

585

$0 \% \quad 12 \%$

4\%

$100 \%$ 
PALLE E-30

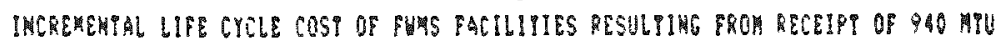

AS PUR ASEEMLIES IN 24 PUR ASSEMLLY TESCS A RRS FACILIY

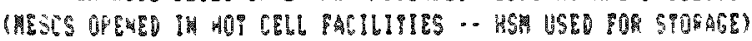

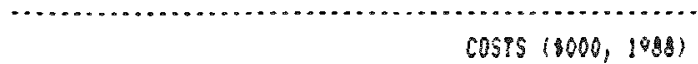

BISC POPAL

EhT cos?

loes hagl?

I OF TOTAL

DISC COSP

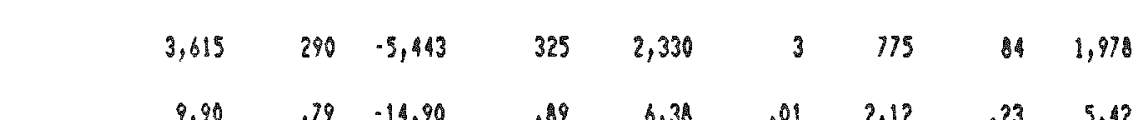

at

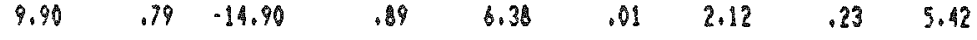

$183 \% \quad 15 \% \quad-275 \% \quad 16 \% \quad 118 \% \quad 0 \% \quad 39 \% \quad 4 \% \quad 100 \%$

\begin{tabular}{|c|c|c|c|c|c|c|c|c|c|c|}
\hline \multicolumn{5}{|c|}{ CAPIIAL COSIS } & \multicolumn{2}{|c|}{ OPERAIIKG } & costs & & & POTAL \\
\hline & $\ldots \ldots$ & $\ldots . . .$. & $\ldots \ldots$ & $\ldots \ldots$ & $\ldots \ldots$ & $\cdots$ & $\ldots \ldots \ldots$ & & & COSIS \\
\hline & Hอ1 & หรพ & & & พับำ & & & & & 15C. \\
\hline & TELL & LOADING & & 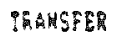 & . B⿺乚 & \$POALGE & MESC & DECOMH & POPAL & $3 \% / 8 p$ \\
\hline YEAR & PACI!IIES & Equip & HSY & CAST & PACIUIIES & AREA & DISPOSAL & cosis & GSPS & 101988 \\
\hline$\ldots$ & 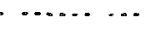 & $\ldots \ldots$ & $\ldots \ldots \ldots$ & $\ldots \ldots \ldots$ & $\ldots \ldots \ldots$ & $\ldots \ldots$ & $\cdots \cdots$ & $\ldots \ldots$ & $\ldots \ldots \ldots$ & $\ldots \ldots$ \\
\hline 1996 & 1,030 & & & & & & & & 1,030 & 786 \\
\hline 1999 & 1,030 & & & & & & & & 1,030 & 74 \\
\hline 2000 & 1,030 & & & & & & & & 1,030 & 722 \\
\hline 2001 & 1,030 & & & & & & & & 1,030 & 701 \\
\hline 2002 & 1,030 & & & & & & & & 1,030 & 681 \\
\hline 2003 & & & & & 175 & & & & 175 & 112 \\
\hline 2004 & & & & & 175 & & & & 175 & 109 \\
\hline 2005 & & & & & 175 & & & & 175 & 106 \\
\hline 2006 & & & & & 175 & & & & 175 & 103 \\
\hline 2507 & & & & & 175 & & & & 175 & 100 \\
\hline 2000 & & & & & 175 & & & & 175 & 97 \\
\hline 2009 & & & & & 175 & & & & 175 & 94 \\
\hline 2010 & & & & & 175 & & & & 175 & 91 \\
\hline 2011 & & & & & 175 & & & & 175 & 89 \\
\hline 2012 & & & & & 175 & & & & 175 & 86 \\
\hline 2013 & & & & & 175 & & & & 175 & 84 \\
\hline 2014 & & & & & 175 & & & & 175 & 1 \\
\hline 2015 & & & & & 175 & & & & 175 & 79 \\
\hline 2016 & & & & & 175 & & & & 175 & 76 \\
\hline 2017 & & 684 & & & 175 & & & & 659 & 365 \\
\hline 2018 & & & $-2,801$ & & 175 & & & & $-2,826$ & $-1,082$ \\
\hline 2019 & & & $-2,801$ & & 175 & & & & $-2,621$ & $-1,050$ \\
\hline 3020 & & & $-2,801$ & & 175 & & & & $-3,826$ & $-1,020$ \\
\hline 2021 & & & $-2,801$ & & 175 & & & & $-2,62 \%$ & -940 \\
\hline 3032 & & & $-2,801$ & & 175 & & & & $-2, b ? 6$ & -961 \\
\hline 2023 & & & & & 175 & & & & 175 & 62 \\
\hline 2024 & & & & & 175 & & & & 175 & 60 \\
\hline 2025 & & & & & 175 & & & & 175 & 59 \\
\hline 2026 & & & & $\therefore, 000$ & 175 & & & & 1,175 & 382 \\
\hline 2027 & & & & & 372 & 10 & 2,453 & & 2,35 & 895 \\
\hline 2028 & & & & & 175 & & & .816 & -411 & .135 \\
\hline 2029 & & & & & 195 & & & & 175 & 52 \\
\hline 2030 & & & & & 175 & & & & 175 & $5 !$ \\
\hline 2031 & & & & & 175 & & & & 175 & 49 \\
\hline 2032 & & & & & 175 & & & & 175 & 48 \\
\hline 2033 & & & & & & & & 1,030 & 1,030 & 272 \\
\hline TOPAL & 5,150 & 684 & $-14,005$ & 1,000 & 5,447 & 10 & 2,453 & 114 & 1,153 & 1,978 \\
\hline
\end{tabular}

\begin{tabular}{|c|c|c|c|c|c|c|c|c|c|c|}
\hline & $\ldots$ & CAPIYAL & OSis & & & ERATING & $\begin{array}{l}\text { coses } \\
\ldots . . . . . .\end{array}$ & & & $\begin{array}{l}\text { POPAL } \\
\text { COSTS }\end{array}$ \\
\hline & Нด & หSิ & & & $40 \%$ & & & & & 156. \\
\hline & TELL & LOADING & & 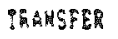 & .84 & SPORAGE & MESC & DECOM⿻ & POPAL & $3 \% / x p$ \\
\hline YEAR & PACULIIES & EQuip & HSM & CASL & FACIUIIIES & AREA & DISPOSAL & cosis & Eosis & 90 1988 \\
\hline & & & & & & & & & & \\
\hline 1998 & 1,030 & & & & & & & & 1,030 & 786 \\
\hline 1999 & 3,030 & & & & & & & & 1,030 & 744 \\
\hline 2000 & 1,030 & & & & & & & & 1,030 & 722 \\
\hline 2001 & 1,030 & & & & & & & & 1,030 & 701 \\
\hline 2002 & 1,030 & & & & & & & & 1,030 & 681 \\
\hline 2003 & & & & & 175 & & & & 175 & 112 \\
\hline 2004 & & & & & 175 & & & & 175 & 109 \\
\hline 2005 & & & & & 175 & & & & 175 & 106 \\
\hline 2006 & & & & & 175 & & & & 175 & 103 \\
\hline 2007 & & & & & 175 & & & & 175 & 100 \\
\hline 2000 & & & & & 175 & & & & 175 & 87 \\
\hline 2009 & & & & & 175 & & & & 175 & 94 \\
\hline 2010 & & & & & 175 & & & & 175 & 91 \\
\hline 2011 & & & & & 175 & & & & 175 & 89 \\
\hline 2012 & & & & & 175 & & & & 175 & 86 \\
\hline 2013 & & & & & 175 & & & & 175 & 84 \\
\hline 2014 & & & & & 175 & & & & 175 & $8 i$ \\
\hline 2015 & & & & & 175 & & & & 175 & 79 \\
\hline 2016 & & & & & 178 & & & & 175 & 76 \\
\hline 2017 & & 684 & & & 175 & & & & 859 & 365 \\
\hline 2018 & & & $-2,801$ & & 175 & & & & $-2,826$ & $-1,082$ \\
\hline 2019 & & & $-2,801$ & & 175 & & & & $-2,628$ & $-1,050$ \\
\hline 2020 & & & $-2,801$ & & 175 & & & & $-9,826$ & $-1,020$ \\
\hline 2021 & & & $-2,801$ & & 175 & & & & $-2,62 \%$ & -990 \\
\hline 2022 & & & $-2,801$ & & 175 & & & & $-2, b 26$ & .961 \\
\hline 2023 & & & & & 175 & & & & 195 & 62 \\
\hline 2024 & & & & & 175 & & & & 175 & 60 \\
\hline 2025 & & & & & 175 & & & & 175 & 58 \\
\hline 2026 & & & & $\therefore, 000$ & 175 & & & & 1,175 & 382 \\
\hline 2027 & & & & & 372 & 10 & 2,453 & & 2,835 & 895 \\
\hline 2020 & & & & & 175 & & & .814 & -411 & .135 \\
\hline 2029 & & & & & 195 & & & & 175 & 52 \\
\hline 2030 & & & & & 175 & & & & 175 & 51 \\
\hline 2031 & & & & & 175 & & & & 175 & 49 \\
\hline 2032 & & & & & 175 & & & & 175 & 48 \\
\hline 2033 & & & & & & & & 1,030 & 1,030 & 272 \\
\hline TOPAL & 5,150 & 688 & $-14,005$ & 1,000 & 5,647 & 10 & 2,453 & 114 & 1,153 & 1,978 \\
\hline
\end{tabular}

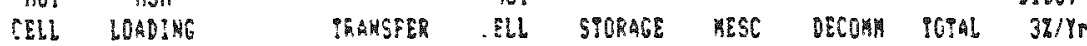

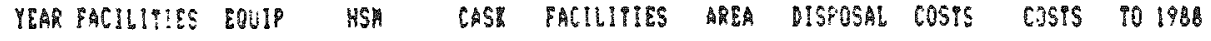

\begin{tabular}{|c|c|c|c|c|c|c|c|c|c|c|}
\hline & $\ldots$ & CAPIYAL & OSis & & & ERATING & $\begin{array}{l}\text { coses } \\
\ldots . . . . . .\end{array}$ & & & $\begin{array}{l}\text { POPAL } \\
\text { COSTS }\end{array}$ \\
\hline & Нด & หSิ & & & $40 \%$ & & & & & 156. \\
\hline & TELL & LOADING & & 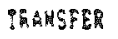 & .84 & SPORAGE & MESC & DECOM⿻ & POPAL & $3 \% / x p$ \\
\hline YEAR & PACULIIES & EQuip & HSM & CASL & FACIUIIIES & AREA & DISPOSAL & cosis & Eosis & 90 1988 \\
\hline & & & & & & & & & & \\
\hline 1998 & 1,030 & & & & & & & & 1,030 & 786 \\
\hline 1999 & 3,030 & & & & & & & & 1,030 & 744 \\
\hline 2000 & 1,030 & & & & & & & & 1,030 & 722 \\
\hline 2001 & 1,030 & & & & & & & & 1,030 & 701 \\
\hline 2002 & 1,030 & & & & & & & & 1,030 & 681 \\
\hline 2003 & & & & & 175 & & & & 175 & 112 \\
\hline 2004 & & & & & 175 & & & & 175 & 109 \\
\hline 2005 & & & & & 175 & & & & 175 & 106 \\
\hline 2006 & & & & & 175 & & & & 175 & 103 \\
\hline 2007 & & & & & 175 & & & & 175 & 100 \\
\hline 2000 & & & & & 175 & & & & 175 & 87 \\
\hline 2009 & & & & & 175 & & & & 175 & 94 \\
\hline 2010 & & & & & 175 & & & & 175 & 91 \\
\hline 2011 & & & & & 175 & & & & 175 & 89 \\
\hline 2012 & & & & & 175 & & & & 175 & 86 \\
\hline 2013 & & & & & 175 & & & & 175 & 84 \\
\hline 2014 & & & & & 175 & & & & 175 & $8 i$ \\
\hline 2015 & & & & & 175 & & & & 175 & 79 \\
\hline 2016 & & & & & 178 & & & & 175 & 76 \\
\hline 2017 & & 684 & & & 175 & & & & 859 & 365 \\
\hline 2018 & & & $-2,801$ & & 175 & & & & $-2,826$ & $-1,082$ \\
\hline 2019 & & & $-2,801$ & & 175 & & & & $-2,628$ & $-1,050$ \\
\hline 2020 & & & $-2,801$ & & 175 & & & & $-9,826$ & $-1,020$ \\
\hline 2021 & & & $-2,801$ & & 175 & & & & $-2,62 \%$ & -990 \\
\hline 2022 & & & $-2,801$ & & 175 & & & & $-2, b 26$ & .961 \\
\hline 2023 & & & & & 175 & & & & 195 & 62 \\
\hline 2024 & & & & & 175 & & & & 175 & 60 \\
\hline 2025 & & & & & 175 & & & & 175 & 58 \\
\hline 2026 & & & & $\therefore, 000$ & 175 & & & & 1,175 & 382 \\
\hline 2027 & & & & & 372 & 10 & 2,453 & & 2,835 & 895 \\
\hline 2020 & & & & & 175 & & & .814 & -411 & .135 \\
\hline 2029 & & & & & 195 & & & & 175 & 52 \\
\hline 2030 & & & & & 175 & & & & 175 & 51 \\
\hline 2031 & & & & & 175 & & & & 175 & 49 \\
\hline 2032 & & & & & 175 & & & & 175 & 48 \\
\hline 2033 & & & & & & & & 1,030 & 1,030 & 272 \\
\hline TOPAL & 5,150 & 688 & $-14,005$ & 1,000 & 5,647 & 10 & 2,453 & 114 & 1,153 & 1,978 \\
\hline
\end{tabular}

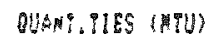

.......................

ANUAL DUAM IIS:

QUAH. $3 \% / Y$ \%

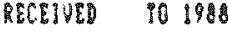


TAMLC E-31

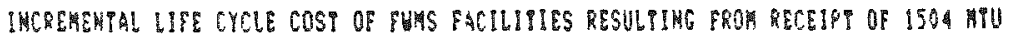

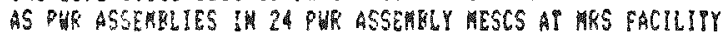

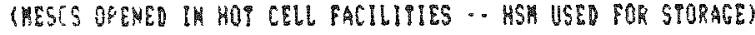

\begin{tabular}{|c|c|c|c|c|c|c|c|c|c|c|c|}
\hline \multicolumn{10}{|c|}{$\operatorname{cosis}(\$ 000,1988)$} & \multicolumn{2}{|c|}{ OUATITIES (HOU) } \\
\hline & CAPIPAL & & & & RAYIBG & COSFS & & & T0Iคน & & \\
\hline & & & $\ldots \ldots$ & $\ldots \ldots$ & .......... & . & & & $\cos T S$ & & \\
\hline Hor & YSH & & & HoI & & & & & $0156+$ & ANXUAL & QUAN DIS: \\
\hline CELL & LOADING & & IKANSFER & CELL & SIOAAGE & $\operatorname{AESC}$ & Decoman & POTAL & $3 \% / Y r$ & WUAS. & $3 \% / Y$ \\
\hline FACILIYIES & EQUPP & HSA & CASI & FACLLIIIES & AREA & DSPOSAL & cosis & cosis & 101988 & RCEIUED & 101988 \\
\hline 更 & ( $\ldots . .$. & & & - & & & & & $\cdots \cdots$ & $\cdots$ & \\
\hline 1,038 & & & & & & & & 1,030 & 766 & & \\
\hline 1,030 & & & & & & & & 1,030 & 744 & & \\
\hline 1,030 & & & & & & & & 1,030 & 722 & & \\
\hline 1,030 & & & & & & & & 1,030 & 701 & & \\
\hline 1,030 & & & & & & & & 8,030 & 881 & & \\
\hline & & & & 175 & & & & 175 & $11 \%$ & & \\
\hline & & & & 175 & & & & 175 & 109 & & \\
\hline & & & & 175 & & & & 175 & 106 & & \\
\hline & & & & 175 & & & & 175 & 103 & & \\
\hline & & & & 175 & & & & 175 & 100 & & \\
\hline & & & & 175 & & & & 175 & 99 & & \\
\hline & & & & 175 & & & & 175 & 94 & & \\
\hline & & & & 175 & & & & 175 & 91 & & \\
\hline & & & & 175 & & & & 175 & $\$ 9$ & & \\
\hline & & & & 175 & & & & 175 & Bs & & \\
\hline & & & & 175 & & & & 175 & 84 & & \\
\hline 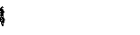 & 684 & & & 178 & & & & 859 & 398 & & \\
\hline 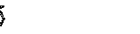 & & $-2,801$ & & 175 & & & & $-2,626$ & $-1,182$ & 188 & 15 \\
\hline & & $-2,801$ & & 175 & & & & $-2,826$ & $-1,148$ & $18 B$ & 82 \\
\hline & & $-2,801$ & & 175 & & & & $-2,626$ & $-1,111$ & 180 & 80 \\
\hline 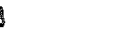 & & $-2,801$ & & 175 & & & & $-2,826$ & $-1,082$ & 158 & 77 \\
\hline & & $-2,801$ & & 175 & & & & $-2,626$ & $-1,050$ & 188 & 75 \\
\hline & & $-2,801$ & & 175 & & & & $-2,826$ & $-1,020$ & 188 & 73 \\
\hline & & $-2,801$ & & 175 & & & & $-2,626$ & -990 & 198 & 71 \\
\hline & & $-2,801$ & & $\$ 75$ & & & & $-2,526$ & .861 & 188 & 67 \\
\hline
\end{tabular}

UMII COST

(per hegl

17

175
175
$17000 \quad 5$

1,000

175

16

$16 \quad 3,425$

$-1,036$

175
175

175

175

175

$-2,526$

82

60

175

175

1,175

4,432

362

1,399

.264

$175 \quad 52$

2030

2031

2032

2033

175

175

175

$1,030 \quad 1,030$

5

48

372

Poial

5,150

$684-22,40$

$1,000 \quad 5,566$

$-6 \quad-5,07$

$-1,293$

2. Of TIAL DSC cos?

$\begin{array}{lllllllll}3,615 & 317 & -9,117 & 325 & 2,367 & 5 & 1,239 & -15 & -1,293 \\ 5,91 & .52 & -11.90 & .53 & 3,87 & .01 & 2.03 & -.07 & -2.11\end{array}$

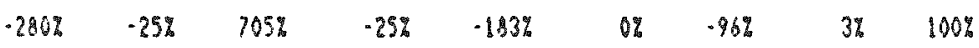


IALLE $8 \cdot 32$

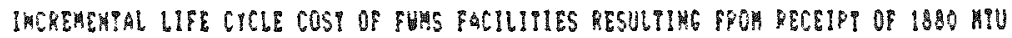

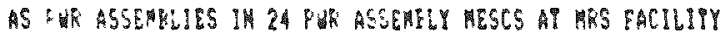

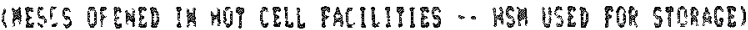

COSPS $(1000,1788)$

\begin{tabular}{|c|c|c|c|c|c|c|c|c|c|c|c|c|}
\hline & ....... & SAPIPAL & osps & $\ldots . .$. & $\begin{array}{r}\text { OP } \\
\ldots . . .\end{array}$ & SRA?IMC & $\begin{array}{l}\text { costs } \\
. . . . . . . . .\end{array}$ & & & $\begin{array}{l}\text { POTHL } \\
\text { COSTS }\end{array}$ & & \\
\hline & Hor & 4Sก & & . & HOP & a & क्षen & & & DIS6, & AHUAL & OUAN DIS: \\
\hline & CELL & LQA3) & & TSA & CELL & SPGAAGE & MESC & Decolsh & POTAL & $3 \% / Y r$ & 口UAн. & $3 \% / y_{n}$ \\
\hline YEA & PACIUIIIES & Euvip & HSH & Cas & PACHUIIES & AREA & DISPOSAL & cosis & COSPS & 901988 & RECEIVED & 101988 \\
\hline ....... & & & & & & & & & ............... & …... & .......... & \\
\hline 198 & 1,030 & & & & & & & & 1,030 & 766 & & \\
\hline 1898 & 1,030 & & & & & & & & 1,030 & 744 & & \\
\hline 2000 & 1,030 & & & & & & & & 1,030 & 722 & & \\
\hline 2001 & 1,030 & & & & & & & & 1,030 & 701 & & \\
\hline 2002 & 1,030 & & & & & & & & 1,030 & 881 & & \\
\hline 2003 & & & & & 175 & & & & 175 & 112 & & \\
\hline 2004 & & & & & 175 & & & & 175 & 109 & & \\
\hline 2905 & & & & & 175 & & & & 175 & 106 & & \\
\hline 2006 & & & & & 175 & & & & 175 & 103 & & \\
\hline 2007 & & & & & 175 & & & & 175 & 100 & & \\
\hline 2008 & & & & & 175 & & & & 175 & 97 & & \\
\hline 2009 & & & & & 175 & & & & 175 & 94 & & \\
\hline 2010 & & & & & 175 & & & & 175 & 81 & & \\
\hline 2011 & & & & & 175 & & & & 175 & 89 & & \\
\hline 2012 & & 684 & & & 175 & & & & 859 & 423 & & \\
\hline 2013 & & & $-2,801$ & & 175 & & & & $-2,626$ & $-1,254$ & 188 & 90 \\
\hline 20114 & & & $-2,801$ & & 175 & & & & $-2, d 26$ & $-1,218$ & 188 & 7 \\
\hline 2015 & & & $-2,801$ & & 175 & & & & $-2,626$ & $-1,182$ & 188 & 35 \\
\hline 2016 & & & $-2,801$ & & 175 & & & & $-2,626$ & $-1,148$ & 188 & 82 \\
\hline 2017 & & & $-2,801$ & & 175 & & & & $-2,626$ & $-1,114$ & 188 & 80 \\
\hline 2018 & & & $-2,809$ & & 175 & & & & $-2,626$ & $-1,082$ & 188 & 37 \\
\hline 2019 & & & $-2,801$ & & 175 & & & & $-2,626$ & $-1,050$ & 108 & 75 \\
\hline 2020 & & & $-2,301$ & & 175 & & & & $-2,626$ & $-1,020$ & 185 & 73 \\
\hline 2021 & & & $-2,801$ & & 175 & & & & $-2,626$ & .990 & 18 & $7 !$ \\
\hline 2022 & & & $-2,801$ & & 175 & & & & $-2,626$ & .981 & 188 & 6 \\
\hline 2023 & & & & & 175 & & & & 175 & 82 & & \\
\hline 2024 & & & & & 175 & & & & 175 & 80 & & \\
\hline 2025 & & & & & 175 & & & & 175 & 59 & & \\
\hline 2028 & & & & $\therefore, 000$ & 195 & & & & 1,175 & 382 & & \\
\hline 2027 & & & & & 570 & 20 & 4,907 & & 5,947 & 1,736 & & \\
\hline 2028 & & & & & 175 & & & $-1,317$ & $-1,142$ & .350 & & \\
\hline 2029 & & & & & 175 & & & & 175 & 52 & & \\
\hline 2030 & & & & & 175 & & & & 175 & 51 & & \\
\hline 2031 & & & & & 175 & & & & 175 & 49 & & \\
\hline 2032 & & & & & 179 & & & & 175 & 40 & & \\
\hline 2033 & & & & & & & & 1,030 & 1,030 & 272 & & \\
\hline TOIAL & 5,150 & 684 & $-26,010$ & 1,000 & 5,645 & 20 & 9,907 & .207 & $-10,891$ & $-3,660$ & 1,800 & 789 \\
\hline
\end{tabular}

GUANIIIES (IPU)

DISC 909AL

Uat Cost

(per hglu)

$\begin{array}{lllll}3,615 & 336 & -11,754 & 325 & 2,342\end{array}$

$6 \quad 1,548 \quad-131 \quad-3,680$

$\begin{array}{lllllllll}4.58 & .43 & -14.90 & .41 & 3.03 & .01 & 1.96 & -.17 & .4 .64\end{array}$

8 OP POPAL

MSC COST

$\begin{array}{llllll}-92 & -65 \% & 0 \% & -42 \% & 48 & 100 \%\end{array}$


TABLE E-33

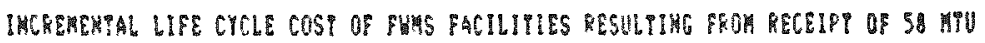

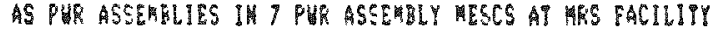

(HESCS UFENES IH HUT CELL PACILITISS .. HSA USEO POR STORAGE)

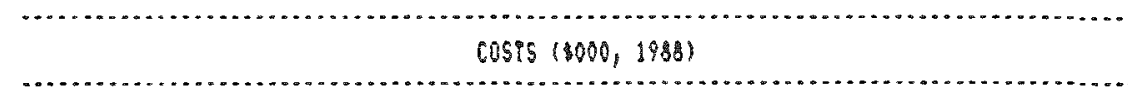

\begin{tabular}{|c|c|c|c|c|c|c|c|c|c|c|c|}
\hline & BAIIAL & cosis & & & EARING & COSTS & & & TOIAL & & \\
\hline$\cdots \cdot$ & .............. & & & $\ldots \ldots$ & & & & & Cosis & & \\
\hline Hot & XSก & & & MoP & & & & & DISG, & AHUUAL & WUAN IS: \\
\hline CELL & LosuInG & & 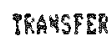 & cEL & SPORAGE & MESC & DECOH & Toral & $3 \% / \varphi_{i}$ & OUAN. & 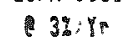 \\
\hline EACIUIIIES & 5 EQuip & หSิ & CAST & FACILIIIES & AREA & DISPDSAL & Cosis & cosis & 101988 & AECEIVED & 101983 \\
\hline
\end{tabular}

\begin{tabular}{|c|c|c|c|c|c|c|c|c|c|c|c|c|}
\hline 1998 & 114 & & & & & & & & 114 & 85 & & \\
\hline 1999 & 191 & & & & & & & & 114 & 2 & & \\
\hline 2000 & 114 & & & & & & & & 114 & 80 & & \\
\hline 2001 & 114 & & & & & & & & 114 & 78 & & \\
\hline 2002 & 114 & & & & & & & & 114 & 75 & & \\
\hline 2003 & & & & & 19 & & & & 19 & 12 & & \\
\hline 2004 & & & & & 19 & & & & 19 & 12 & & \\
\hline 2005 & & & & & 19 & & & & 19 & 11 & & \\
\hline 2006 & & & & & 19 & & & & 19 & 11 & & \\
\hline 2007 & & & & & 19 & & & & 19 & 11 & & \\
\hline 2008 & & & & & 19 & & & & 19 & 11 & & \\
\hline 2009 & & & & & 19 & & & & 19 & 10 & & \\
\hline 2010 & & & & & 19 & & & & 18 & 10 & & \\
\hline 2011 & & & & & 19 & & & & 19 & 10 & & \\
\hline 2012 & & & & & 19 & & & & 19 & 9 & & \\
\hline 2013 & & & & & 19 & & & & 19 & 8 & & \\
\hline 2011 & & & & & 19 & & & & 19 & 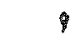 & & \\
\hline 2015 & & & & & 19 & & & & 19 & 9 & & \\
\hline 2016 & & & & & 19 & & & & 19 & 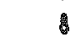 & & \\
\hline 2017 & & & & & 19 & & & & 19 & . & & \\
\hline 2018 & & & & & 19 & & & & 19 & 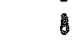 & & \\
\hline 2019 & & 76 & & & 18 & & & & 95 & 38 & & \\
\hline 2020 & & & & & 18 & & & & 19 & 7 & & \\
\hline 2021 & & & & & 19 & & & & 19 & 7 & & \\
\hline 2022 & & & -252 & & 19 & & & & .233 & -85 & 58 & 21 \\
\hline 2023 & & & & & 18 & & & & 19 & 7 & & \\
\hline 2024 & & & & & 19 & & & & 19 & 7 & & \\
\hline 2025 & & & & & 18 & & & & 18 & 6 & & \\
\hline 2026 & & & & $\therefore, 000$ & 19 & & & & 1,019 & 331 & & \\
\hline 2027 & & & & & 56 & 2 & 202 & & 262 & 83 & & \\
\hline 2028 & & & & & 19 & & & 41 & 80 & 10 & & \\
\hline 2024 & & & & & 19 & & & & 19 & $\$$ & & \\
\hline 2030 & & & & & 19 & & & & 19 & 5 & & \\
\hline 2031 & & & & & 19 & & & & 19 & 5 & & \\
\hline 2032 & & & & & 19 & & & & 19 & 5 & & \\
\hline 2033 & & & & & & & & 114 & 114 & 30 & & \\
\hline POPAL & 570 & 76 & -252 & 1,000 & 609 & 2 & 202 & 155 & 2,302 & 1,029 & 58 & 21 \\
\hline
\end{tabular}

DISC IOTAL

UMII COST [ner hogu

$100 \quad 30$

18.951.

.92

325

259

$1 \$ 8$

43,029

2 OF TOIAL DISC COST

$\begin{array}{lllllllll}39 \% & 3 \% & -9 \% & 32 \% & 25 \% & 0 \% & 6 \% & 47 & 100 \%\end{array}$


TAELE E-34

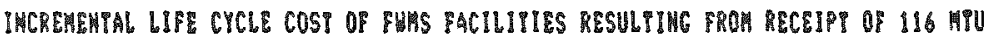

AS PUF ASSERDLIES IN 7 PUT ASEEABLY MESCS AI MRS FACULIYY

(MESCS OPEHED IH HOP CCLL FACULIYIES - HSH USED FOR STORACE)

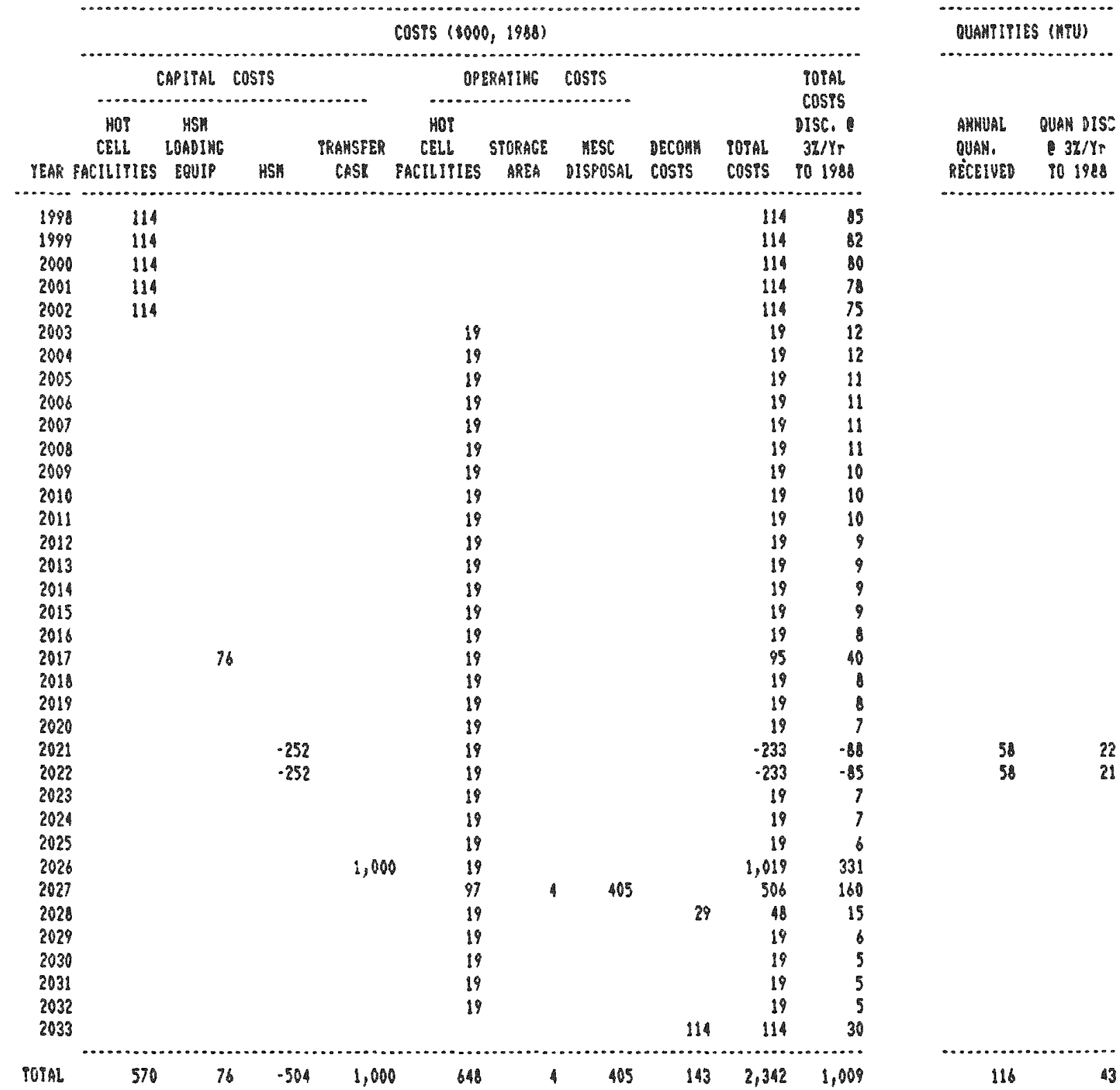

QUAMTIPIES (MTU)

DSS TOIAL

UMI COST

(ดer haju)

$\begin{array}{lllllllll}400 & 32 & -187 & 325 & 271 & 1 & 129 & 39 & 1,009\end{array}$

$\begin{array}{lllllllll}9.25 & .75 & -4.34 & 7.55 & 6.28 & .03 & 2.97 & .91 & 23.42\end{array}$

IOF POPAL

DISC COST

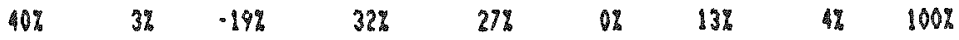


PAMLE \&-35

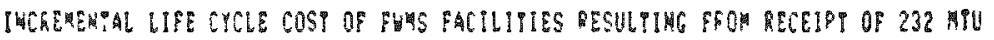

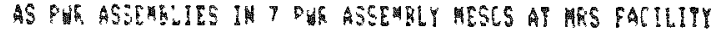

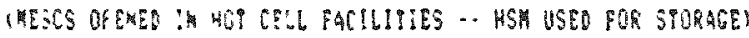

Cosis (1000, 1988)

\begin{tabular}{|c|c|c|c|c|c|c|c|c|c|}
\hline & CAPITAL & Cosis & & & ERATING & COSPS & & & \\
\hline Hoi & HSM & & & HOP & & & & & 015 \\
\hline CELL & 15:4:AG & & TKAУSFER & CELL & STORAGE & 解SC & DEcon & TOTAL & \\
\hline YEA GACIUIIES & EuUlP & HS & CASI & FACILIIIES & AREA & DISPOSAL & cosis & cosis & \\
\hline
\end{tabular}

$\begin{array}{ll}1990 & 114 \\ 1599 & 114 \\ 2900 & 114 \\ 2001 & 114 \\ 2002 & 114\end{array}$

2003

2004

2005

2008

2007

2008

2009

2010

2011

2012

2013

2014

2015

2018

2017

$20: 5$

2919

2020

2021

2022

2 เิ23

2024

2025

2026

2027

2028

2029

2030

2031

2032

2033

TOTAL

$$
\begin{aligned}
& 114 \\
& 114 \\
& 114 \\
& 114
\end{aligned}
$$

78

.852

.252

.852

$.25 ?$

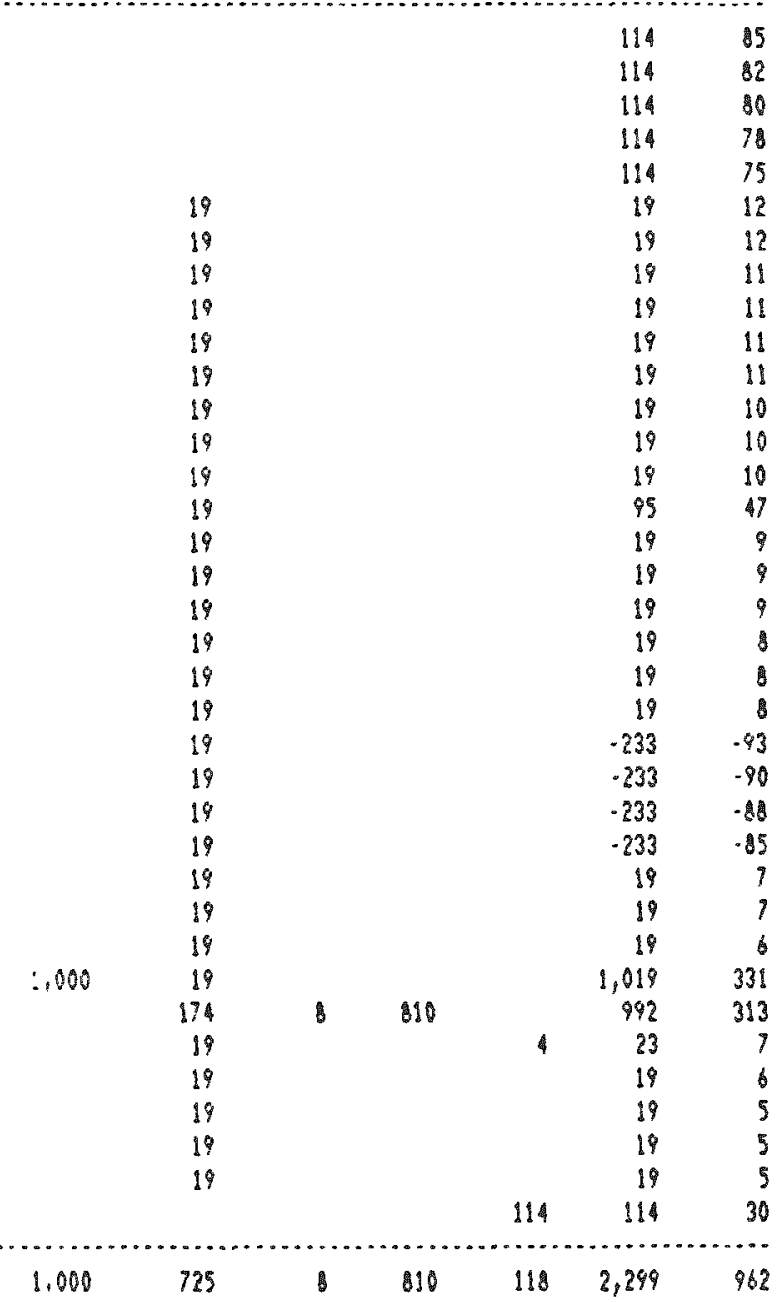

DISE MCPLL

UKII CosT

(per bậ]

Y OP IJPAL

DISC COST

QUAMITIES (MTU)

ANGUAL QUAG JIS:

QUAR. $3 \% / Y-$ RECEIUES PO 1988 
PALER C-36

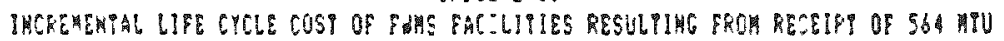

AS PU ASSEMLIES IH 24 PUR ASSERLY MESCS AP MRS FACILITY

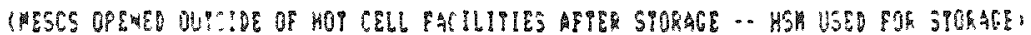

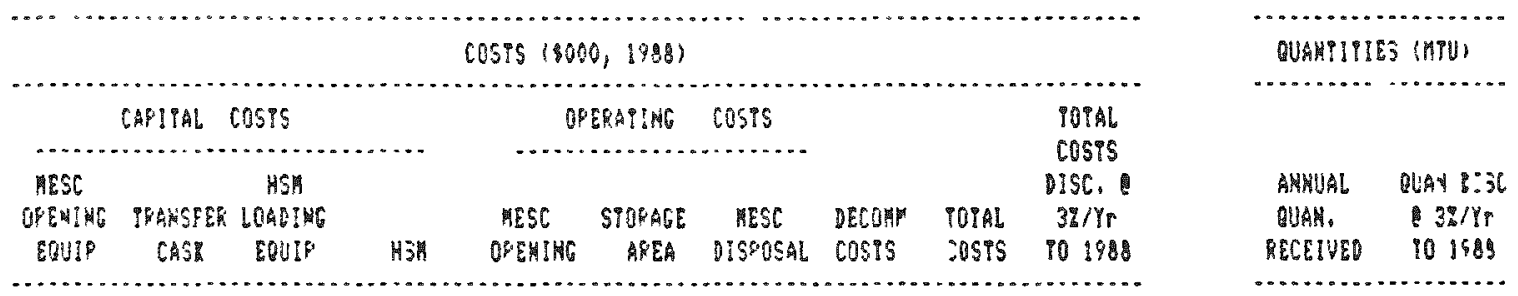

1998

1999

2000

2001

2002

2003

2304

2005

2006

2007

2808

2009

2010

2011

201 ?

2013

2014

2015

2018

2017

2010

2019

2028

2021

2022

2023

2024

2025

2026

2027

2028

$399 \quad 1,000$

684

$-2,801$

$-\hat{z}, 301$

$-2,801$

$\begin{array}{rr}884 & 274 \\ -2,801 & -1,088 \\ -2,801 & -1,056 \\ -2,801 & -1,025\end{array}$

188

188

73

7
49

2029

2030

2031

2032

2033

TลโAน

..................

684 $-2,403$

166

( 1,472

.316

$1,399 \quad 455$

186

$130 \quad 325$

$274 \quad-3,169$

59

2

465

$\begin{array}{ll}-17 & -2,012\end{array}$

UHIT :อร?

(per kgill

$.81 \quad 1.53$

1.29

.11 .90

.28

101

2.19

. $.48 \quad .9 .46$

\% OF gotal

DISC COS?

$\begin{array}{lllllllll}-6 \% & -16 \% & -14 \% & 159 \% & -3 \% & 0 \% & -23 \% & 5 \% & 100 \%\end{array}$


PABLE E-37

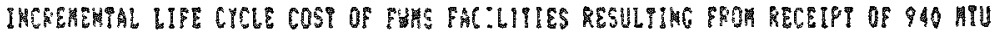

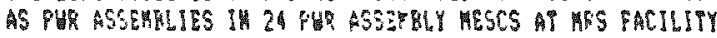

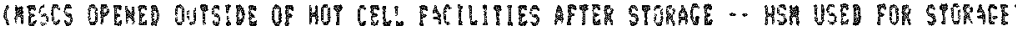

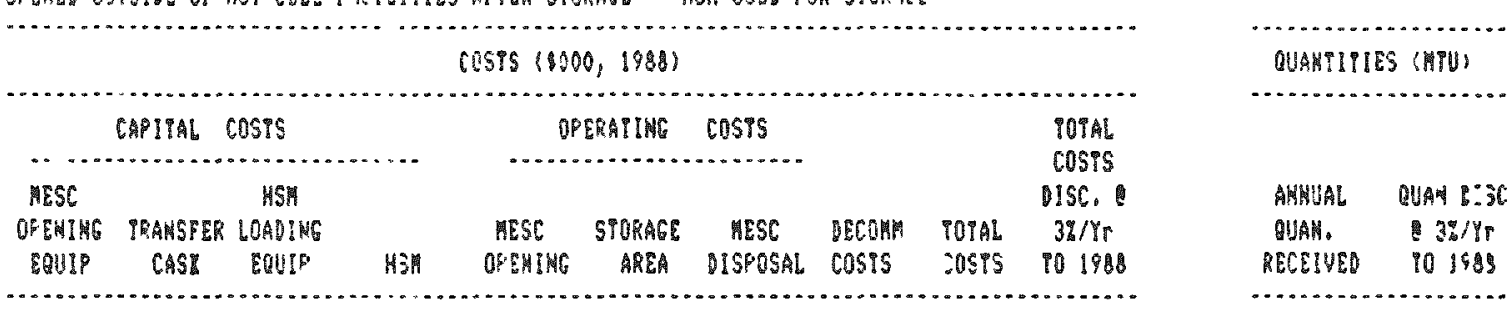

1998

199

2000

2001

2002

2003

2004

2009

2096

2007

2000

2009

2010

2011

2012

2013

2014

2015

2016

2017

2018

2018

2020

2021

2022

2023

2024

2025

604

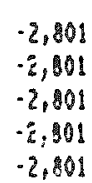

$-2,801$

$-2,001$

$-8 ; 301$

2,801
202

2027

2028

2029

2030

2031

2032

2033

$399 \quad 1,000$

TưAL

DIsC 90Pal

UMIT cos?

(per hl)

I OF TOIAL ISC cos?

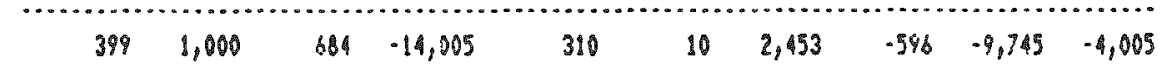

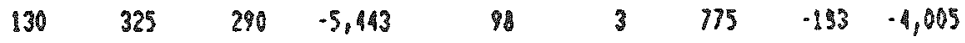

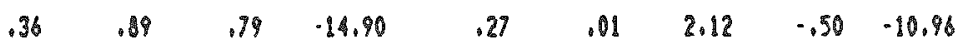

684290

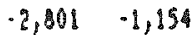

$-2,801-1,120$

$-2,801-1,088$

$-2,801 \quad-1,056$

$-2,301 \quad-1,025$

$\begin{array}{rrrrr}310 \quad 10 & 2,453 & & 1,399 & 455 \\ & & & 2,773 & 876 \\ & & .546 & .596 & -183\end{array}$

78

.


PABLE $\mathrm{E}-3 \mathrm{~B}$

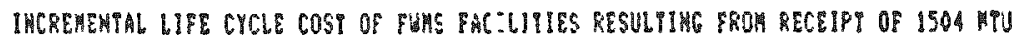

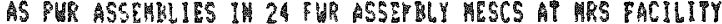

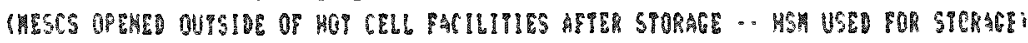

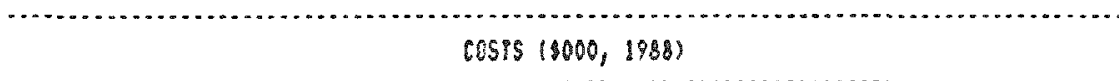

OUAMIIIIES : MTU)

\begin{tabular}{|c|c|c|c|c|c|c|c|c|c|c|c|}
\hline & CAPITAL & cosis & & & KATING & cosis & & & TOPAL & & \\
\hline yaman & $\cdots$ & $\cdots \ldots$ & $\ldots$ & & & & & & costs & & alsos $=90$ \\
\hline $\begin{array}{l}\text { AESC } \\
\text { OPEHIHE }\end{array}$ & THAWSFER & $\begin{array}{c}\text { MSP } \\
\text { LOADING }\end{array}$ & & 琎 & SPORACE & IESC & Decom & $10 \% \mathrm{AL}$ & $\begin{array}{l}\text { DISC. } \\
3 \% / Y_{r}\end{array}$ & $\begin{array}{l}\text { AHWUAL } \\
\text { OUAM. }\end{array}$ & $\begin{array}{c}\text { QUA B.SL } \\
\text { C 3\% }\end{array}$ \\
\hline EOUIP & CASR & EQuI\% & $45 \mathrm{H}$ & OFEHIMG & AREA & DISPOSAL & cosis & gosts & 101988 & RECEIVED & 10 ISA \\
\hline
\end{tabular}

1998

1999

2000

3001

2002

2003

2004

2005

2006

2007

3008

2009

2010

3011

2012

2013

2014

2015

2016

2017

2018

2019

2020

$302 !$

2022

2023

2024

2025

3026

$399 \quad 1,000$

스용

$-2,301$

$-2,801$

$+, 601$

$-2,301$

$-2,801$

$-2,201$

$-5,301$

$-2,801$

ล58 317

$-2,801 \quad-1,281$

:, $001-1,224$

$-2,801 \quad-1,189$

$-2,501 \quad-1,154$

$-2,801-1,120$

$-2,301-1,030$

$-2,801 \quad-1,056$

$-2,801-1,025$

$\begin{array}{ll}188 & 95 \\ 188 & 9 ? \\ 188 & 90 \\ 188 & 77 \\ 188 & 75 \\ 188 & 73 \\ 188 & 71 \\ 188 & 39\end{array}$

2027

2028

2029

2030

2031

2032

2033

I0IAL

$399 \quad 1,000$

$$
684-22,408
$$

498

$$
\begin{array}{lllrr}
498 & & & 1,399 & 155 \\
\quad 16 & 3,925 & & 1,437 & 1,401 \\
& & -1,016 & -1,016 & -311
\end{array}
$$

DISC MUTAL

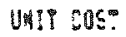

(per $n g y)$

$\begin{array}{rrrrrrrrr}130 & 325 & 317 & -.8117 & 157 & 5 & 1,239 & -311 & -7,256 \\ .21 & .53 & .52 & -11.30 & .26 & .01 & 2.03 & -.51 & -11.86\end{array}$

- OF POPAL

DisC c0s?

$\begin{array}{lllllllll}-22 & -4 \% & -4 \% & 125 \% & -2 \% & 0 \% & -17 \% & 4 \% & 100 \%\end{array}$


PARL: E-39

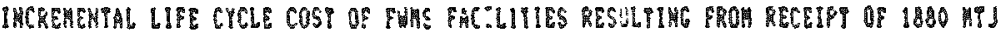

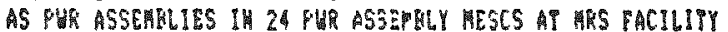

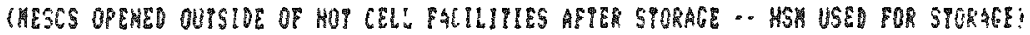

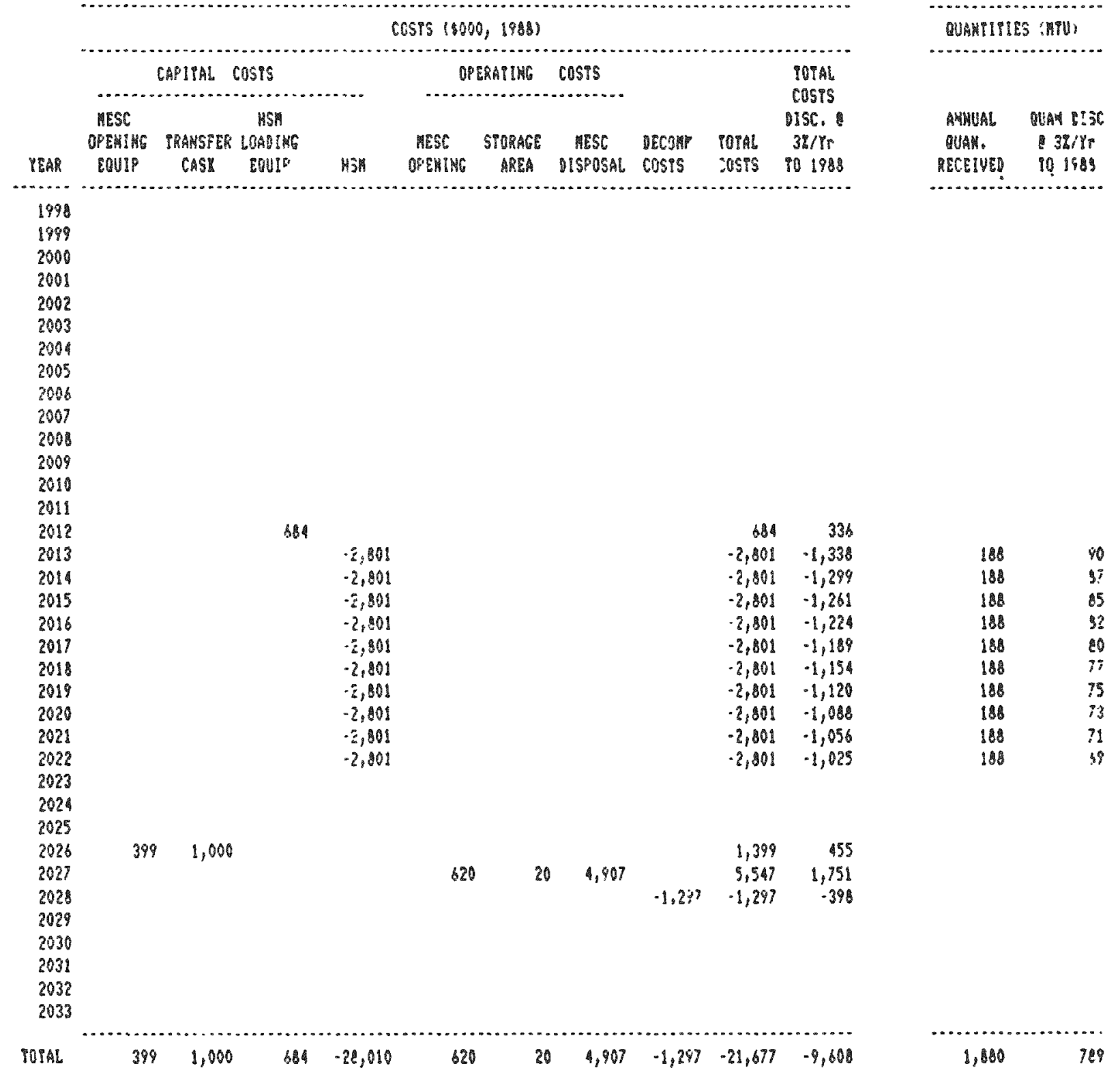

QUARIIIIES :MTU

MISC MOTAL

$130 \quad 325 \quad 336 \quad-51,754 \quad 196 \quad 6 \quad 1,544 \quad-318 \quad-8,805$

Uมा :

(per agl)

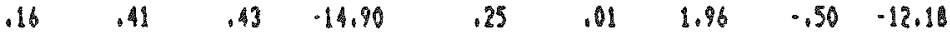

D. OT TOTAL

Disc cosi

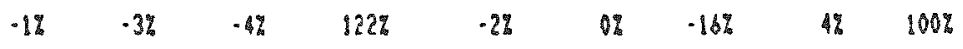


IABL: $8-40$

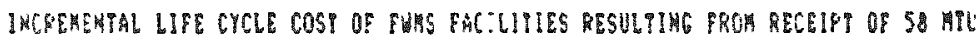

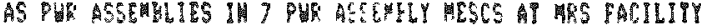

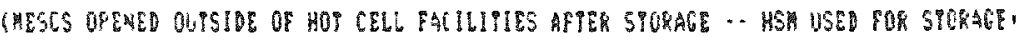

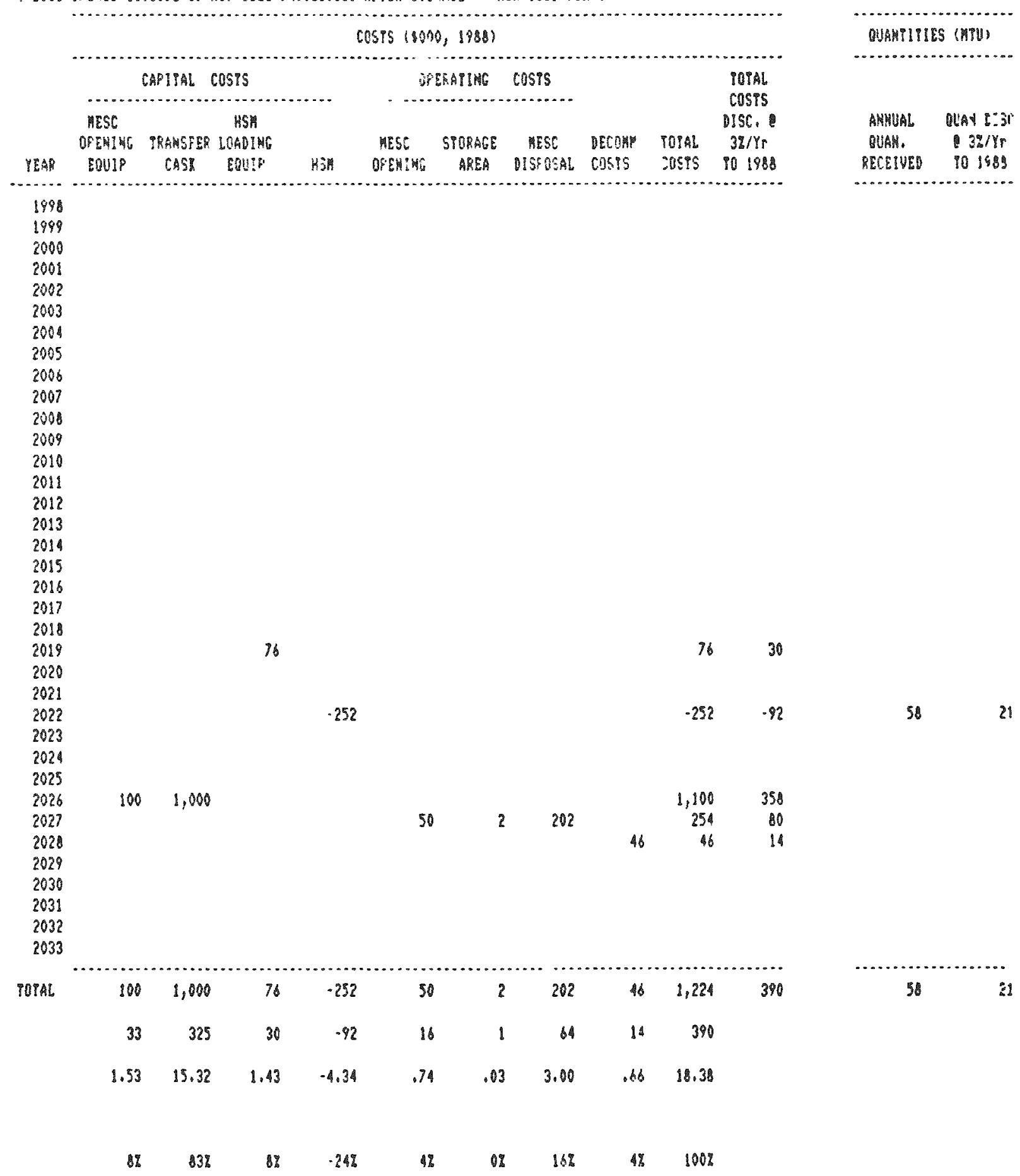

DISC TOTh

Wxit cos?

(per haj)

* of jotal

Dise cosis

$\begin{array}{lllllllll}8 \% & 8 \% & -24 \% & 4 \% & 0 \% & 15 \% & 4 \% & 100 \%\end{array}$


TARES E-A1

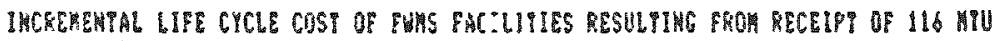

AS PUR ASSERBLIES IH 7 PUK MESEMLY MESES AI KRS FACILIPY

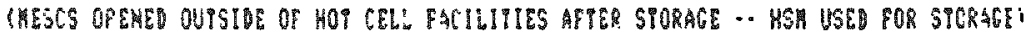

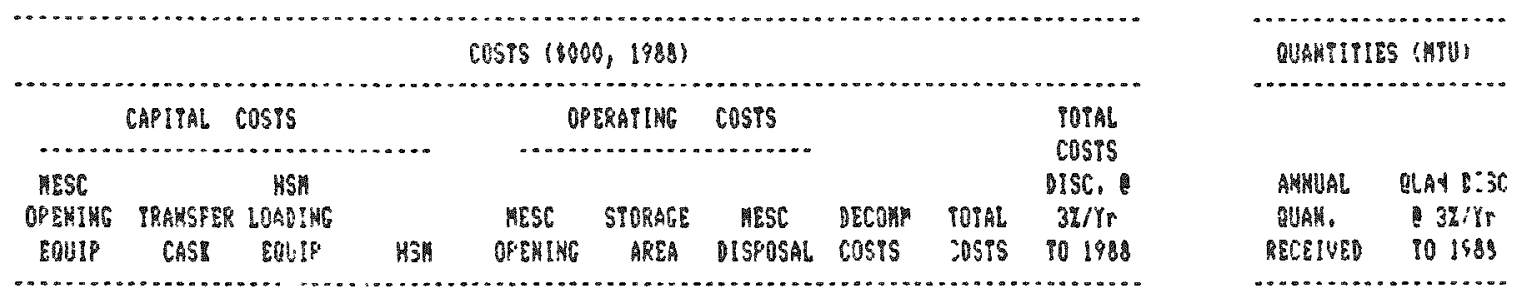

1998

1999

2000

3001

2002

2003

2004

2005

2006

2007

2008

2009

2010

2011

2012

2013

2014

2015

2016

2017

2018

2019

2020

2021

2022

2023

2024

8025

2026

2027

2028

2029

2030

2031

2032

2033

POPAL.
76

$100 \quad 1,000$
$-252$

.252

บISC บ0?ง

U⿻上丨𣥂

(per hyll

I OF DOTAL

DIŚc cos?

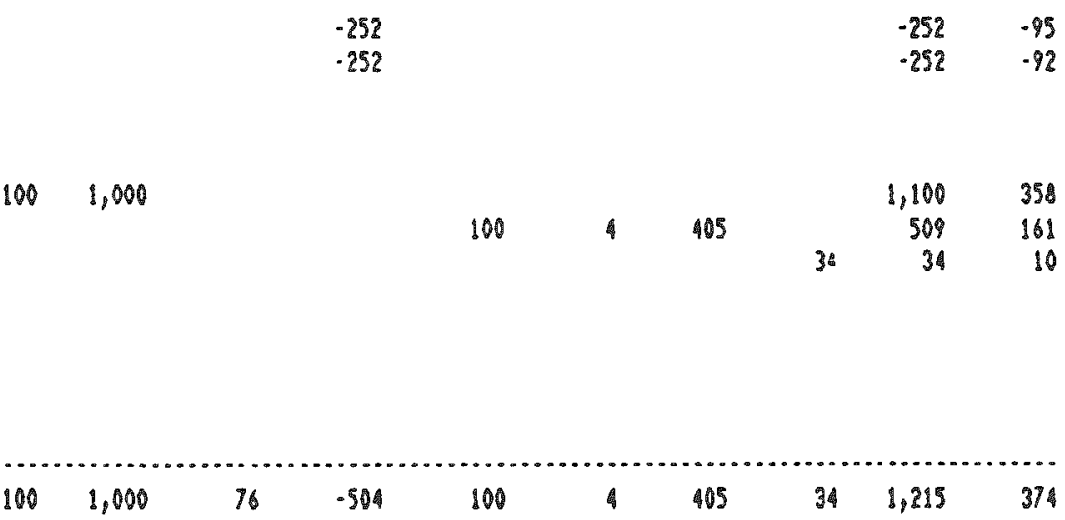

$\begin{array}{rrrrrrrrr}33 & 325 & 32 & .187 & 32 & 1 & 128 & 10 & 374 \\ .75 & 7.55 & .75 & -4.34 & .73 & .03 & 2.97 & .24 & 8.68\end{array}$

$92 \quad 97 \% \quad 92 \quad 50 \% \quad 8 \% \quad 0 \% \quad 345 \quad 32 \quad 100 \%$

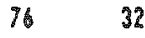

58

22

58 
PABLE E-1?

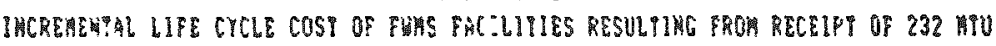

AS PUR ASSEHRLIES IN 7 PUR RSSERELY MESCS AT HPS FACLLIYY

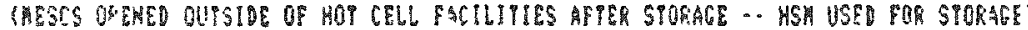

\begin{tabular}{|c|c|c|c|c|c|c|c|c|c|c|c|}
\hline \multicolumn{10}{|c|}{ Cosis 16000,1958$)$} & \multicolumn{2}{|c|}{ WUAMIIIES (MTU) } \\
\hline & CAPIIAL & cosis & & & Enatiag & COSTS & & & POPAL & & \\
\hline$\ldots$ & . . . . n & ........ & & & & & & & Costs & & \\
\hline MESC & & KS界 & & & & & & & BISC. & AWHUAL & QUAV I:30 \\
\hline OPEATHC & PRANSPEA & D LOAING & & 苟C & SPORAGE & MESC & DECOAP & TOIAL & $3 \% / Y$ & อบคนด. & $3 \% / 4 r$ \\
\hline EQuIP & CASL & Eout & H漂 & OPEHIHG & $A R E A$ & DSPOSAL & $\operatorname{cosis}$ & 30575 & 101988 & RECEIVED & 10158 \\
\hline
\end{tabular}

1996

1898

2000

2001

2002

2003

2004

2005

2006

2007

2005

2009

2010

2011

$201 ?$

2013

कि:"

2615

2016

2017

2018

2019

2020

2021

2022

2023

2021

2025

2026
2027

$100 \quad 1,000$

76

76

37

2028

2029

2030

2031

2032

2033

YUPAL

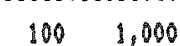

1,000

$76-1,008$

$\begin{array}{llll}33 & 325 & 37 & -386\end{array}$

63

.3) 3.66

.42

$\cdot .34$

.71

3

810

258

$9 \quad 1,195$

333

UWIT 200 :

(pen nol)

2 OP YoTaL

UISC 6059

$10 \% \quad 98 \% \quad 11 \% \quad-116 \%$

$\begin{array}{llll}.03 \quad 2.08 & .03 \quad 3.75\end{array}$

$\begin{array}{ll}-252 & -101 \\ -252 & -98 \\ -252 & -95 \\ .252 & -92\end{array}$

$\begin{array}{ll}58 & 33 \\ 58 & 23 \\ 58 & 22 \\ 58 & 21\end{array}$

232

89 


\begin{tabular}{|c|c|c|c|c|c|}
\hline \multirow[b]{2}{*}{ Year } & \multicolumn{2}{|c|}{ Costs Incurred } & \multicolumn{3}{|c|}{ Value of Service } \\
\hline & $\begin{array}{c}\text { Total } \\
\text { Annual Costs }\end{array}$ & $\begin{array}{l}\text { Discounted } \\
3 \% / Y r \text { To } 1989\end{array}$ & $\begin{array}{c}\text { Total } \\
\text { Annual Costs }\end{array}$ & $\begin{array}{l}\text { Disco } \\
3 \% / Y r\end{array}$ & $\begin{array}{l}\text { Unted } \\
\text { To } 1989 \\
\end{array}$ \\
\hline $\begin{array}{l}1989 \\
1990 \\
1991 \\
1992 \\
1993 \\
1994 \\
1995 \\
1996 \\
1997 \\
1998 \\
1999\end{array}$ & $\begin{array}{r}\$ 100.0 \\
5.0 \\
5.0 \\
5.0 \\
5.0 \\
5.0 \\
5.0 \\
5.0 \\
5.0 \\
5.0 \\
5.0 \\
\end{array}$ & $\begin{array}{r}\$ 100.0 \\
4.9 \\
4.7 \\
4.6 \\
4.4 \\
4.3 \\
4.2 \\
4.2 \\
3.9 \\
3.8 \\
3.7 \\
\end{array}$ & $\begin{array}{l}\$ 10.0 \mathrm{C} \\
10.0 \mathrm{C} \\
10.0 \mathrm{C} \\
10.0 \mathrm{C} \\
10.0 \mathrm{C} \\
10.0 \mathrm{C} \\
10.0 \mathrm{C} \\
10.0 \mathrm{C} \\
10.0 \mathrm{C} \\
10.0 \mathrm{C}\end{array}$ & $\$$ & $\begin{array}{l}9.7 C \\
9.4 C \\
9.2 C \\
8.9 C \\
8.6 C \\
8.4 C \\
8.1 C \\
7.9 C \\
7.7 C \\
7.4 C\end{array}$ \\
\hline Total & $\$ 150.0$ & $\$ 142.7$ & $\$ 100.0 \mathrm{C}$ & & $85.3 \mathrm{C}$ \\
\hline
\end{tabular}

$\bar{a}$ Number of units times the levelized unit cost $(C)$.

This levelized unit cost of $\$ 1.6723 /$ unit is the unit cost that when escalated at the inflation rate and applied to the specific quantities involved, will provide enough money to pay all costs that are incurred, inflated as appropriate, plus imputed interest on the difference between the costs incurred and the payments made (or benefits accrued). This is demonstrated in the following table which shows the cash flows involved for two different combinations of inflation rates and money values, with the ratios between the two being held constant at ${ }^{1} .03$. 


\section{Inflated \\ Cost \\ Value of
Service \\ Amount Cost Is \\ In Excess of \\ Value Received}

Imputed Interest
On Excess At
Indicated
Value
of Money

No Inflation; Value of Money $3 \%$

\begin{tabular}{|c|c|c|c|c|}
\hline $\begin{array}{l}1989 \\
1990 \\
1991 \\
1992 \\
1993 \\
1994 \\
1995 \\
1996 \\
1997 \\
1998 \\
1999\end{array}$ & $\begin{array}{r}\$ 100.0 \\
5.0 \\
5.0 \\
5.0 \\
5.0 \\
5.0 \\
5.0 \\
5.0 \\
5.0 \\
5.0 \\
5.0 \\
\end{array}$ & $\begin{array}{r}\$ 16.7 \\
16.7 \\
16.7 \\
16.7 \\
16.7 \\
16.7 \\
16.7 \\
16.7 \\
16.7 \\
16.7 \\
\end{array}$ & $\begin{array}{r}\$ 100.0 \\
91.3 \\
82.3 \\
73.1 \\
63.6 \\
53.8 \\
43.7 \\
33.3 \\
22.6 \\
11.6 \\
.3\end{array}$ & $\$$ \\
\hline Total & $\$ 150.0$ & $\$ 167.0$ & & \\
\hline
\end{tabular}

$6.8 \% / \mathrm{Vr}$. Inflation; Value of Money $10 \%$

\begin{tabular}{lrrrr}
1989 & 100.0 & & 100.0 & 10.0 \\
1990 & 5.3 & 17.9 & 97.4 & 9.7 \\
1991 & 5.7 & 19.1 & 93.7 & 9.4 \\
1992 & 6.1 & 20.4 & 88.8 & 8.9 \\
1993 & 6.5 & 21.8 & 82.4 & 8.2 \\
1994 & 6.9 & 23.2 & 74.3 & 7.4 \\
1995 & 7.4 & 24.8 & 64.3 & 6.4 \\
1996 & 7.9 & 26.5 & 52.1 & 5.2 \\
1997 & 8.5 & 28.3 & 37.5 & 3.8 \\
1998 & 9.0 & 30.2 & 20.1 & 2.0 \\
1999 & 9.7 & $\$ 32.3$ & -.5 & $\$ 71.0$ \\
\hline
\end{tabular}

a Number of units times the levelized unit costs, escalated to the time service is performed at the indicated inflation rate.

From the foregoing it can be seen that the value of service exactly lexcept for rounding) offsets the inflated costs plus the imputed interest on costs unrecovered by service value. This demonstrates the suitability of this method of determination of levelized unit cost. It also illustrates the significance of the levelized unit cost under two typical ways of doing long- 
term cost evaluations: the first way, with zero inflation, is frequently called the "constant dollar" evaluation; the second way, with actual inflation (and actual interest) is frequently called the "actual dollar" evaluation. In the "constant dollar" evaluation, the unit cost is the "constant-follar" unit cost that is recovered (or accrued) for all units of the product, at al1 times. In the "actual dollar" evaluation, the unit cost is the unit cost at time zero, and the actual unit cost collected (or accrued! in subsequent years is this time-zero unit cost, multiplied by the escalation factor appropriate to the time of production. 


\section{INTERNAL DISTRIBUTION}

\author{
1. J. M. Begovich \\ 2. G. Cowart \\ 3. A. G. Croff \\ 4 - 8. E. J. Frederick \\ 9. R. K. Genung \\ 10. I. G. Harrison \\ 11. E. K. Johnson \\ 12. D. S. Joy \\ 13. S. B. Ludwig \\ 14. W. C. McClain \\ 15. A. P. Malinauskas \\ 16. K. J. Notz \\ 17. J. E. Ratledge
}

18. R. R. Rawl

19. W. J. Reich

20. I. B. Shappert

21. M. G. Stewart

22. M. W. Wankerl

23. Central Research Library

24. Document Reference Section

25-26. Laboratory Records

27. Laboratory Records - RC

28. ORNL Patent Section

\section{EXTERNAL DISTRIBUTION}

DOE - ORO, P. O. BOx 2001. Oak Ridge. TN 37831

29. Office of Assistant Manager, Energy Research and Development.

DOE - Office of Civilian Radioactive Waste Management. Forrestal Building. 1000 Independence Avenue. S. W. Washington, DC 20585

30. L. H. Barrett

31. A. B. Brownstein

32. J. H. Carlson

33. W. J. Danker

34. H. J. Hale

35. C. Kouts

36. T. Pollog

37. D. E. Shelor

38. R. Stein

39- 242. E. Svenson

243. J. Williams

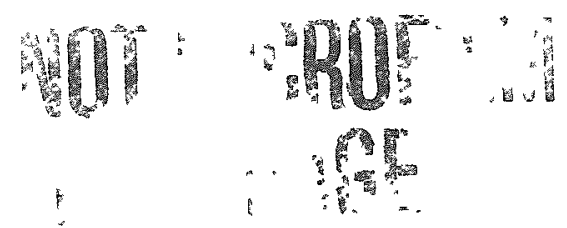


DOE - Office of Nuclear Encrgy, 19901 Germantown Rd., Germantown, MD 20874

244. J. A. Tori

DOE - Chicago Operations Oflice, 9800 S. Cass Ave., Chicago. II. 60439

245. R. S. Rothman

DOE - Idaho Operations Office, 785 DOE Place, Idaho Falls, ID 83402

246. M. J. Barainca

DOE - Nevada Operations Office, P. O. Box 98518, Las Vegas, NV 89113

247. E. Wilmot

DOE - Richland Operations Office, P. O. Box 550, Richland, WA 99352

248. D. Langstaft

Pacific Northwest Laboratory, P. O. Box 999, Richland, WA 99352
249. G. H. Beeman
250. L. L. Clark
251. M. Kreiten
252. P. N. McDuffic
253. R. W. McKee
254. G. W. McNair
255. T. Wood

Sandia National Laboratory, P. O. Box 5800, Albuquerque, NM 87185

256. G. Allen

257. A. W. Dennis

Battelle/OSTP, 505 King Ave., Columbus, OH 43201

258. D. Dippold

259. P. Hollman

Edison Electric Institute, 111119 th Street NW. Washington, D.C. 20036

260. J. Flaherly, UWASTE

SU.S. GOVERNMENT PRINTING OFFICE 1990-748 114/00141

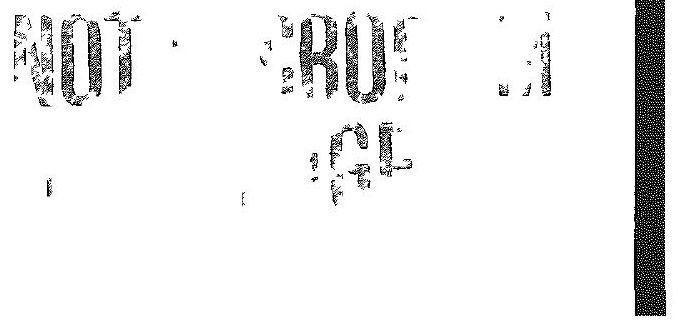


EG\&G Idaho, Inc., P. O. Box 1625 Idaho Falls, ID 83415

261. J. Leatham

Electric Power Research Institute, P. O. Box 10412, Palo Alto, CA 94303

262. R. W. Lambert

263. R. Williams

E. R. Johnson Associates, Inc., 10461 White Granite Drive., Suite 204, Oakton, VA 22124

264. N. B. McLeod

265. B. M. Cole

Nuclear Assurance Corp., 6251 Crooked Creek Road, Suite 200, Norcross, GA 30092

266. N. Mote

Science Applications Int. Corp., 800 Oak Ridge Turnpike, Oak Ridge, Tennessee 37830

267. R. W. Peterson

Science Applications Int. Corp., 101 Convention Center Dr., Las Vegas, NV 89109

268. R. Morrisette

Roy F. Weston, Inc., 955 L'Enfant Plaza, SW., Eighth Floor, Washington, D.C. $2(0) 24$

269. G. Bradley

270. J. DiNunno

271. P. Bolton

272 - 533. Given distribution as shown in DOE/OSTI-4500-R75 under Transportation of Nuclear Materials and Spent Fuel Storage, Categories UC-513 and UC-812. 